Universidade de São Paulo

Faculdade de Medicina de Ribeirão Preto

Departamento de Farmacologia

\title{
Papel da enzima indoleamina 2,3- dioxigenase (IDO) na imunossupressão induzida pela sepse
}

Ribeirão Preto 


\section{Papel da enzima indoleamina 2,3- dioxigenase (IDO) na imunossupressão induzida pela sepse}

Tese apresentada à Faculdade de Medicina de

Ribeirão Preto da Universidade de São Paulo para a obtenção do título de Doutor em Ciências.

Área de concentração: Farmacologia

Orientador: Prof. Dr. José Carlos Farias Alves-Filho

Ribeirão Preto 
Autorizo a reprodução e divulgação total ou parcial deste trabalho, por qualquer meio convencional ou eletrônico, para fins de estudo e pesquisa, desde que citada a fonte.

\section{Ficha Catalográfica}

Ferreira, Raphael Gomes

Papel da enzima indoleamina 2,3-dioxigenase (IDO) na imunossupressão induzida pela sepse.

Ribeirão Preto, 2016.

102p.

Tese de doutorado apresentada ao Programa de Pós-Graduação em Ciências. Área de concentração: Farmacologia - Faculdade de Medicina de Ribeirão Preto da Universidade de São Paulo.

Orientador: José Carlos Farias Alves Filho

Palavras Chaves: Sepse, CD11c, AhR, Células $T$ reguladoras, Imunossupressão, Indoleamina 2,3- dioxigenase (IDO). 


\section{FOLHA DE APROVAÇÃO}

Raphael Gomes Ferreira

Papel da enzima indoleamina 2,3-dioxigenase (IDO) na imunossupressão induzida pela sepse

Tese apresentada à Faculdade de Medicina de Ribeirão Preto da Universidade de São Paulo para a obtenção do título de Doutor em Ciências.

Área de concentração: Farmacologia

Aprovado em:

\section{Banca examinadora:}

Prof. Dr. José Carlos Farias Alves Filho Instituição: FMRP-USP Assinatura:

Prof. Dr. Antônio Pazin Filho

Instituição: FMRP-USP Assinatura:

Prof. Dr. Vanessa Carregaro Pereira

Instituição: FMRP-USP Assinatura:

Prof. Dr. Felipe Dal Pizzol

Instituição: UNESC

Assinatura:

Prof. Dr. Alexandre Salgado Basso

Instituição: EPM-UNIFESP Assinatura: 
Trabalho realizado no Laboratório de Dor e Inflamação do Departamento de Farmacologia da Faculdade de Medicina de Ribeirão Preto - Universidade de São Paulo e no Laboratório de Farmacologia do Departamento de Medicina experimental e Ciências Bioquímicas - Università Degli Studi Di Perugia com auxílio financeiro da Fundação de Amparo à Pesquisa do Estado de São Paulo (FAPESP) 
Dedico esta tese aos meus pais, Ailton Fernando Ferreira e Ruth Gomes Ferreira. Obrigado. O que vocês fizeram nunca será recompensado. Vocês acreditaram... 


\section{Agradecimentos:}

Agradeço inicialmente ao Professor José Carlos Farias Alves Filho, que abriu as portas do laboratório de Inflamação e Dor (LID), oferecendo o apoio e infraestrutura necessários à realização deste trabalho. Obrigado pelos ensinamentos técnicos e cobranças que me fizeram desenvolver um olhar científico crítico. Aos Professores Fernando de Queiroz Cunha e Thiago Mattar Cunha, pelo suporte técnico necessário para o desenvolvimento deste trabalho.

A Professora Francesca Fallarino da Università degli Studi di Perugia, Itália, que me recebeu durante a realização do Estágio de Pesquisa no Exterior para a realização dos experimentos utilizando os camundongos deficientes para o AhR.

Obrigado aos amigos Daniele Nascimento, Paulo Melo, Annie Rocio, Douglas Prado, Denis Augusto e Guilherme Rabelo que colaboraram diretamente para a realização deste trabalho.

Obrigado aos meus colegas do laboratório de Dor e Inflamação, pela convivência saudável, contribuindo para minha formação humana, além de fornecer suporte emocional nos momentos de tensão: Andressa de Freitas, Larissa Garcia Pinto, Paula Giselle Czaikoski, Rafael Sanches Peres, Fernanda Castanheira, Jhimmy Talbot, Jaqueline Raymond, Alexandre Kanashiro, Adriana de Souza, Jozi Godoy, Cristina Setin, Guilherme Rabelo de Sousa, Rafael Poloni, Paula Barbim, Mirian, Bruno Melo, Flávio Protásio Veras, João Paulo, Luis Eduardo Damasceno, Paula Viacava, André Saraiva, Cássia Regina da Silva, Andressa Urba, Andressa Duarte, Vanessa Borges, 
Dênis Augusto, Kalil Lima, Matheus, Joana, David Colòn, Marcela Davoli, Maria Claudia, Rafaela Mano, Carlos Yroshi, Janaina Andrate, Maurício Motta, Caio Abner, Flávia Cecília, Gabriel e Letícia.

Obrigado a todos os colegas Pós-graduandos do Departamento de Farmacologia, pela acolhimento e convivência durante a caminhada.

Agradeço aos amigos: Diva Amábile, Ana Kátia dos Santos, Fabíola Leslie Mestriner, Sérgio Roberto Rosa, Giuliana Bertozi, Tadeu Franco Vieira, Denise Brufato Ferraz, leda Regina dos Santos e Marco Antônio pelo suporte técninco.

Obrigado aos bioteristas pelo cuidado com os animais e pela amizade: Orlando, Maria Inês Nemoto e Eliana Beatriz Castrechini.

Grato aos colegas que trabalham na secretaria do departamento de Farmacologia e na secretaria do departamento de Biologia Celular e Molecular, Bioquímica e Imunologia: José Waldik Ramon, Sonia Maria Stefanelli de Andrade, Fátima Pestean, Ana Cristine.

Agradeço em muito ao Conselho Nacional de Desenvolvimento Científico e Tecnológico (CNPq) e a Fundação de Amparo à Pesquisa do Estado de São Paulo (FAPESP) pelo auxílio financeiro que possibilitou a realização deste trabalho. 
Sou grato aos meus familiares, pois, sem vocês, nada teria acontecido. 
Quanto ao mais, irmãos, tudo o que é verdadeiro, tudo o que é honesto, tudo o que é justo, tudo o que é puro, tudo o que é amável, tudo o que é de boa fama, se há alguma virtude, e se há algum louvor, nisso pensai.

Filipenses 4:8 
Resumo

Ferreira, R.G. Papel da enzima indoleamina 2,3-dioxigenase (IDO) na imunossupressão induzida pela sepse. Tese de doutorado - Departamento de Farmacologia da Faculdade de Medicina de Ribeirão Preto - Universidade de São Paulo, Ribeirão Preto, SP.

Em alguns casos, pacientes que sobreviveram a uma sepse grave podem desenvolver um quadro de imunossupressão, caracterizado pela expansão dos linfócitos $\mathrm{T}$ reguladores (Tregs). Porém, apesar de inúmeros avanços, os mecanismos associados à expansão das Tregs, ainda não estão completamente esclarecidos. Nesse sentido, trabalhos recentes demonstraram que a atividade da enzima Indoleamina 2,3-Dioxigenase (IDO), responsável pela formação da quinurenina a partir da degradação do aminoácido essencial triptofano, está relacionada à diferenciação das Tregs e com o desenvolvimento de um quadro de tolerância. Dessa forma, o objetivo deste estudo foi investigar o papel da IDO no desenvolvimento da imunossupressão induzida pela sepse. Os resultados demonstraram um aumento da expressão proteica e da atividade enzimática da IDO no baço de camundongos que sobreviveram à sepse grave. Para avaliar o desenvolvimento da imunossupressão, os camundongos foram desafiados com células do melanoma B16-F10. A inibição farmacológica da IDO reduziu a intensidade da imunossupressão induzida pela sepse, o que foi evidenciado pela redução do crescimento tumoral. Adicionalmente, foi demonstrado que, o receptor de hidrocarbonetos de arila $(A h R)$ está associado ao aumento da expressão da IDO, nos camundongos que sobreviveram à sepse. Ainda, os resultados demonstraram que células $C 11 c^{+}$são as principais responsáveis por 
expressar a IDO no baço de camundongos que sobreviveram à sepse. Por fim, células CD11 $\mathrm{C}^{+}$isoladas do baço de camundongos que sobreviveram a sepse, foram mais efetivas em induzir a diferenciação das Tregs quando comparadas a células $\mathrm{CD}_{11 \mathrm{C}^{+}}$provenientes de camundongos naive. Em conjunto, os resultados sugerem que a ativação do AhR durante a fase aguda da sepse é importante para expressão da IDO nas células $\mathrm{CD} 11 \mathrm{C}^{+}$encontradas no baço de camundongos que sobreviveram à sepse, o que por sua vez, está associado com a expansão das Tregs e com o desenvolvimento do quadro de imunossupressão.

Palavras chave: Sepse, CD11c, AhR, Células T reguladoras, Imunossupressão, Indoleamina 2,3- dioxigenase (IDO). 
Abstract

Ferreira, R.G. Role of enzyme Indoleamine 2, 3-dioxygenase (IDO) in the development of sepsis-induced immunosuppression. Thesis (PhD) Department of Pharmacology - Ribeirão Preto Medical School - University of São Paulo, Ribeirão Preto, SP.

Immunosuppression has been shown to be one long-term sequels of severe sepsis, which is mainly characterized by the expansion of regulatory $\mathrm{T}$ cells (Tregs). However, the mechanisms underlying Tregs expansion after sepsis remain poor understood. Indoleamine 2,3-dioxygenase (IDO), an enzyme that initiates the kynurenine pathway of tryptophan degradation, has been implicated in promoting Tregs generation. Therefore, we propose to investigate the role of IDO in the development of sepsis-induced immunosuppression. The results presented here demonstrated that there is an increase in both IDO protein expression and IDO enzymatic activity in spleen of sepsis-surviving mice. We employed a melanoma mouse model as a second challenge to evaluate the immunosuppression development in sepsis-surviving mice. We found that pharmacological inhibition of IDO suppressed the enhancement of tumor growth observed in sepsis-surviving mice. In agreement, inhibition of IDO decreased the expansion of Tregs in sepsis-surviving mice. Our results suggest that aryl hydrocarbon receptor $(\mathrm{AhR})$ is associated with increased IDO expression found in sepsis-surviving mice. Furthermore, we identified that a CD11 $\mathrm{c}^{+}$population of cells are expressing IDO in spleen of sepsis surviving mice. In addition, CD11c ${ }^{+}$ cells isolated from spleen of sepsis-surviving mice, presented a higher capacity to induce a regulatory phenotype in naïve CD4+ ${ }^{+}$D25- $T$ than $C D 11 c^{+}$isolated 
from naïve mice. Taken together, our results suggest that AhR activation during acute phase of sepsis is important to IDO expression in $\mathrm{CD} 11 \mathrm{C}^{+}$population. This new sepsis-induced $\mathrm{CD} 11 \mathrm{C}^{+} \mathrm{IDO}^{+}$population is important to Treg cells expansion and immunosuppression development in sepsis-surviving mice.

Keywords: Sepsis, CD11c, AhR, Regulatory T cells, Immunosuppression, Indoleamine 2,3-dioxygenase (IDO). 


\section{Lista de abreviaturas}

AhR: Receptor de hidrocarboneto de arilo

C5a: componente do complemento $5^{\text {a }}$

CLP: Ligadura e perfuração do ceco

CpG: Oligodeoxinucleotídeo

CTLA-4: Cytotoxic T-lymphocyte associated antigen 4

DC: célula dendrítica

EDTA: Ácido etilenodiaminotetracético

FMRP: Faculdade de Medicina de Ribeirão Preto

G: Gauge

GCN2: general control nonderepressible 2

h: hora

$\mathrm{H}_{2} \mathrm{O}_{2}$ : peróxido de hidrogênio

HEPES: (4-(2-hydroxyethyl)-1-piperazineethanesulfonic acid ) - tampão

i.p.: Intraperitoneal

i.v.: Intravenoso

IDO: indoleamina 2,3-dioxigenase

IFN-Y: Interferon- gama

IL: Interleucina

Kg: Quilograma

$\mathrm{KMO}$ : quinurenina 3-monooxigenase

KO: Nocaute (Knockout)

Kyn: Quinurenina

L: Litro

LPS: Lipopolissacarideo derivado de E. coli cepa 0157

MDSC: myeloid-derived suppressor cells

mg: miligrama

MHC-II: compleco de histocompatibilidade principal II ml: mililitro

MPO: Mieloperoxidase 
mTOR: Mammalian Target of Rapamycin

$\mathrm{NaCl}$ : Cloreto de sódio

NFK-B: Fator de transcrição nuclear Kappa B

NO: Óxido nítrico

PAMP: padrão molecular associado à patógeno

PBS: Solução salina tamponada fosfatada

PCR: Polymerase Chain Reaction

PD-1: programmed death-1

pmol: picomol

PRR: receptores de reconhecimento de padrões

RNA: Ácido ribonucléico

ROS: Espécies reativas derivadas de oxigênio

RPMI-1640: Roswell Park Memorial Institute (meio de cultura)

SBF: Soro bovino fetal Albumina sérica bovina

ST2: TIR-domain-containing receptor ST2

TDO: L-triptofano 2,3-dioxigenase

TGF- $\beta$ : transforming growth factor

TLR: Toll-Like Receptor

TNF-alfa: Fator de necrose tumoral alfa

Treg: linfócitos T regulador

Try: Triptofano

USP: Universidade de São Paulo

UTI: unidades de tratamento intensivo

WT: Wild type

$\mu \mathrm{L}$ : Microlitro 


\section{SUMÁRIO}

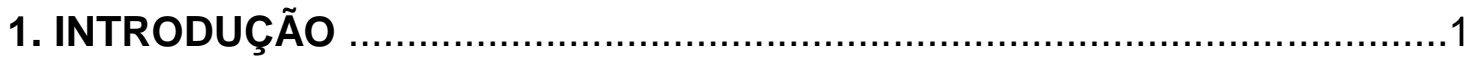

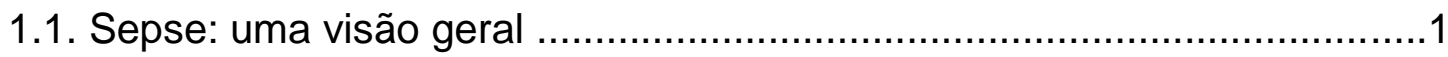

1.2. Imunossupressão induzida pela sepse ………................................... 4

1.3. A enzima indoleamina 2,3 dioxigenase (IDO) no contexto da sepse ....... 8

1.4. A enzima indoleamina 2,3 dioxigenase (IDO) em um contexto de

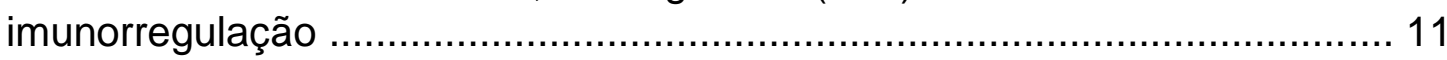

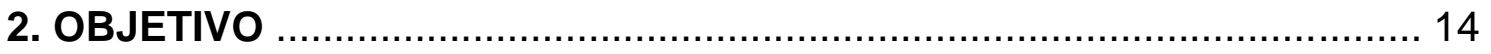

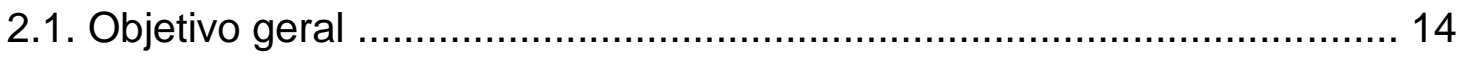

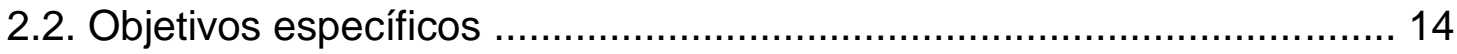

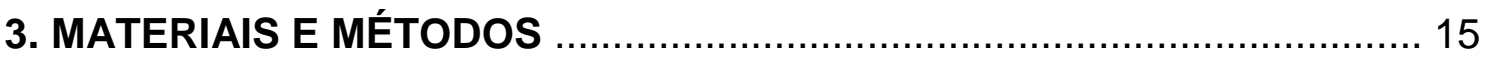

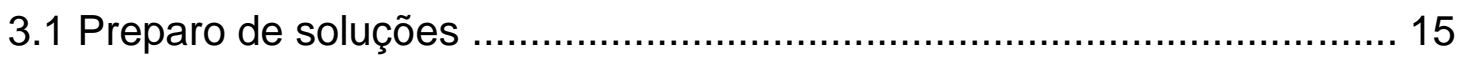

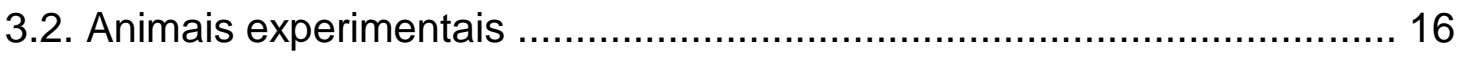

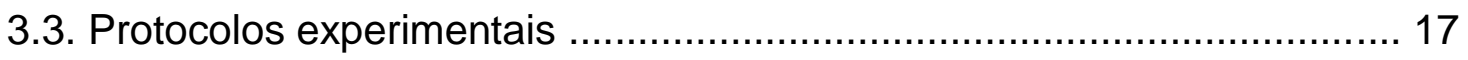

3.3.1. Determinação da taxa de sobrevida de camundongos submetidos a uma sepse grave e tratados com antibiótico .......................................... 17

3.3.2. Avaliação do papel da quinurenina no agravamento da sepse ........ 17

3.3.3. Determinação da cinética de expressão proteica e da produção de

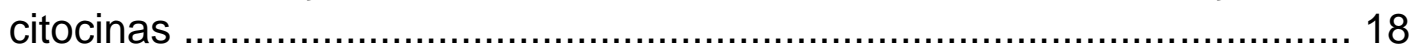

3.3.4. Avaliação do papel da IDO no desenvolvimento de macrófagos M2 e

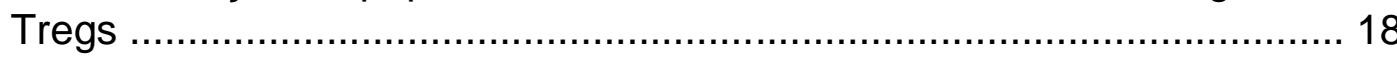

3.3.5. Avaliação do papel da IDO no desenvolvimento da imunossupressão

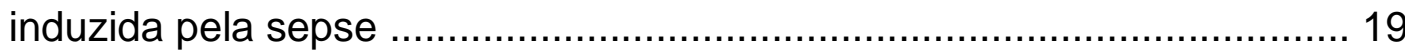

3.3.6. Avaliação do papel de macrófagos M2, interferon e (IFN)-y na regulação da expressão proteica da IDO ………….............................. 20

3.3.7. Avaliação do papel do AhR na regulação da expressão proteica da

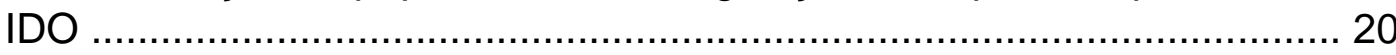

3.4. Modelo experimental de imunossupressão induzida por sepse ............. 21

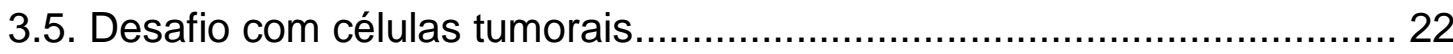

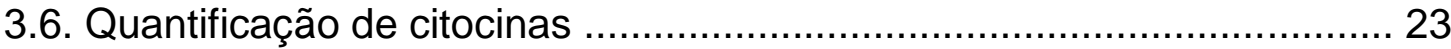

3.7. Avaliação da expressão gênica da IDO do AhR e da KMO por real timeRT PCR 
3.8. Avaliação da expressão proteica por Western Blotting ......................... 25

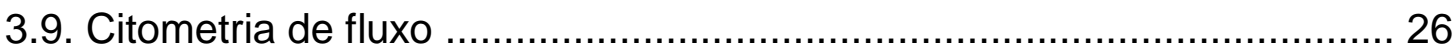

3.10. Quantificação dos níveis de quinurenina no soro ……....................... 27

3.11. Ensaio para avaliação da atividade enzimática da IDO ....................... 28

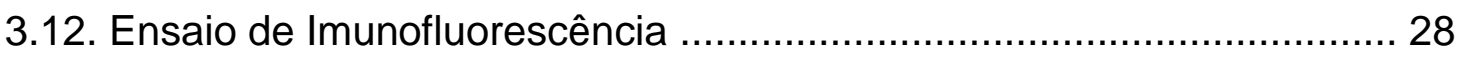

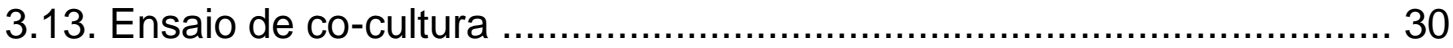

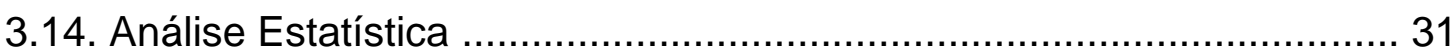

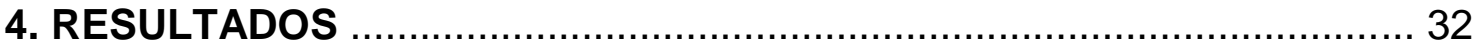

4.1. Avaliação do desenvolvimento da imunossupressão induzida após a

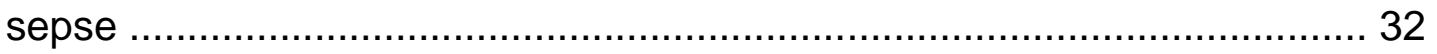

4.2. Avaliação da expressão da IDO e da KMO em camundongos

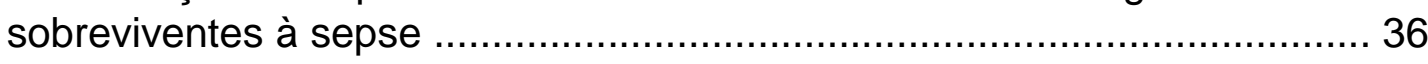

4.3. Avaliação da razão quinurenina/triptofano e da atividade enzimática da IDO em camundongos sobreviventes à sepse

4.4. Avaliação do papel da IDO no desenvolvimento da imunossupressão

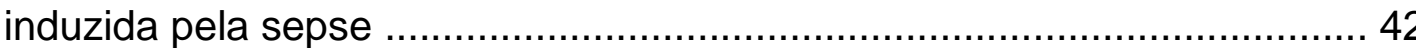

4.5. Avaliação do papel da IDO na expansão de Tregs observada em camundongos sobreviventes à sepse

4.6. Avaliação dos mecanismos associados ao controle do crescimento tumoral após o tratamento com inibidor da IDO ........................................ 46

4.7. Avaliação das vias associadas ao aumento da expressão proteica da IDO em camundongos sobreviventes à sepse .............................................. 49

4.8. Caracterização da célula responsável pela expressão da IDO no baço de camundongos sobreviventes à sepse

4.9. Avaliação da capacidade das células $C D 11 \mathrm{c}^{+}$provenientes de camundongos que sobreviveram à sepse de induzir a diferenciação das Tregs

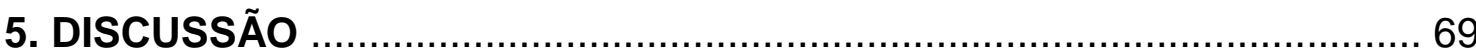

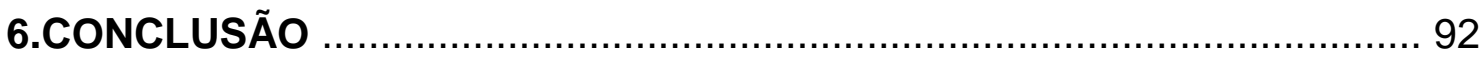

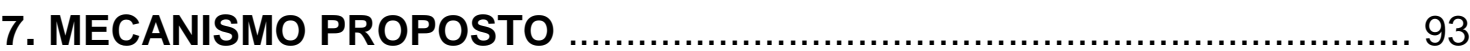

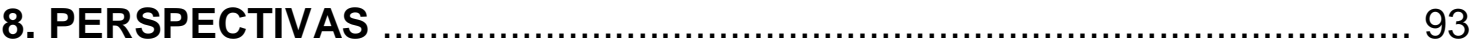

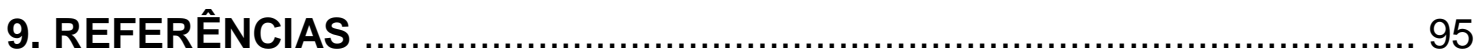

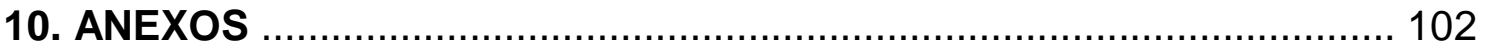




\section{INTRODUÇÃO}

\subsection{Sepse: uma visão geral}

O Termo sepse é utilizado para definir uma disfunção de órgão causada por uma resposta desregulada do hospedeiro a uma infecção, podendo levar a morte (Singer et al., 2016). Os sinais e sintomas iniciais da sepse são aqueles associados ao quadro de uma inflamação aguda, incluindo febre ou hipotermia, taquipnéia, taquicardia, leucopenia ou leucocitose, podendo evoluir para uma disfunção múltipla de órgão, choque séptico e morte (Victor et al., 2004). Por se tratar de uma síndrome que apresenta sinais e sintomas muitas vezes opostos e comuns aos encontrados em outros quadros, a construção de uma definição eficaz se torna difícil. Assim, pesquisadores e clínicos tem se mobilizado com o objetivo de aperfeiçoar as definições utilizadas, o que poderá auxiliar no diagnóstico, contribuindo para um tratamento mais eficiente e para construção de um banco de dados internacional mais confiável, facilitando a realização e comparação de estudos multicêntricos (Cohen et al., 2015).

Não existem dúvidas de que nas últimas décadas muitos avanças foram realizados, permitindo a descoberta de vários mecanismos associados à fisiopatologia da sepse e suas consequências. Porém, apesar de muitas pesquisas, os índices de mortalidade de pacientes internados em unidades de tratamento intensivo (UTI) americanas em decorrência de sepse continuam crescendo com taxa de mortalidade variando em torno de 30 a $70 \%$, sendo que, o custo para o tratamento desses pacientes é calculado em 16,7 bilhões de dólares por ano (Hotchkiss et al., 2003; Hotchkiss et al., 2013a; Cohen et al., 2015). Ainda, um estudo realizado pelo Centro de Controle de Doenças (CDC) 
em hospitais americanos, revelou que a incidência de pacientes com sepse saltou de 73,6 em 100,000 no ano de 1979, para 175,9 em 100,000 no ano 1989 (Angus et al., 2001). Por fim, mais de 750,000 pacientes por ano nos Estudados Unidos desenvolvem sepse e estima-se que esse número cresça 1,5\% ao ano (Cohen, 2002; Hotchkiss et al., 2003).

No Brasil, ainda existem poucos estudos sobre incidência e mortalidade em decorrência da sepse, possivelmente pela dificuldade de acesso do paciente a centros de saúde especializados, e mesmo quando isso acontece, pela dificuldade de um diagnóstico rápido e preciso. Apesar das dificuldades, o estudo BASES (Brazilian Sepsis Epidemiogical Study) que avaliou 1,383 pacientes em UTIs de São Paulo e Santa Catarina, revelou uma incidência de 46,9 \% com mortalidade de 33,9 \% (Silva et al., 2004). Outro estudo realizado por Sales et al., (2006) avaliou 3,128 pacientes em 75 UTIs de todas as regiões do país e revelou incidência de $16,7 \%$ e mortalidade de 46,6\% (Sales et al., 2006). Por fim, segundo o Instituto Latino Americano de Sepse (2008), os gastos anuais com pacientes sépticos no Brasil situam-se em 17,34 bilhões de reais, sendo que desses, 9,88 bilhões foram utilizados com o tratamento de pacientes que não sobreviveram à afecção. Portanto, a sepse possui grande significância clínica e implicações financeiras, atraindo grande interesse científico (Weycker et al., 2003).

Com relação a fisiopatologia da sepse, sabe-se que as respostas apresentadas pelo organismo durante o desenvolvimento desta síndrome são resultado de uma complexa interação entre microrganismos e hospedeiro. Essa interação se dá por meio de moléculas constitutivamente expressas na superfície dos patógenos e denominadas padrões moleculares associados à patógenos 
(PAMPs). Os PAMPs são reconhecidos por receptores expressos na superfície de neutrófilos, macrófagos e células dendríticas, coletivamente denominados, receptores de reconhecimento de padrões (PRRs), sendo que, os membros mais conhecidos desta família são os receptores Toll-like (TLRs) (Takeda et al., 2003). Neste sentido, foi demonstrado que camundongos deficientes para a expressão dos receptores TLR-2, TLR-4 ou TLR-9, quando submetidos a uma sepse letal, irão apresentar uma resposta mais branda quando comparados a camundongos wild type (WT) (Alves-Filho et al., 2006; Alves-Filho et al., 2009; Trevelin et al., 2012).

O reconhecimento do agente infeccioso pelos PRRs (Hotchkiss et al., 2003) leva a ativação do sistema imune, com consequente desenvolvimento de um quadro inflamatório que envolve a participação de mecanismos de defesa celular e humoral (Riedemann et al., 2003). Nesse contexto, as células endoteliais e epiteliais, além de macrófagos, neutrófilos e linfócitos, passam a produzir vários mediadores inflamatórios, dentre eles, fator de necrose tumoral$\alpha$ (TNF- $\alpha$ ), interleucina (IL)-6, IL-1 e IL-8. Simultaneamente, ocorre elevada produção de proteínas de fase aguda, como a proteína C reativa, além da ativação do sistema do complemento que leva à produção de C5a, molécula próinflamatória capaz de estimular a produção de mais citocinas e quimiocinas (Wagner et al., 2010). Nesse momento, também ocorre ativação da cascata de coagulação, que pode ocorrer por vários mecanismos, levando a um quadro de coagulopatia disseminada (Riedemann et al., 2003).

Os diversos mediadores produzidos em grande quantidade durante a fase aguda da sepse revelam um estado hiperativo do organismo. Este processo progressivo levará a ativação de células do sistema imune inato, principalmente 
de neutrófilos. Diante do excesso de estímulos pro-inflamatórios liberados durante a progressão de uma sepse grave, os neutrófilos serão ativados ainda na circulação sanguínea, perdendo a capacidade de migrar para o foco infeccioso. Nestes casos, os neutrófilos irão se acumular em diferentes tecidos passando a liberar enzimas granulares e espécies reativas de oxigênio (ROS), principalmente, peróxido de hidrogênio $\left(\mathrm{H}_{2} \mathrm{O}_{2}\right)$. Este processo irá promover lesão tecidual e aumento da permeabilidade vascular, levando a um extravasamento de plasma excessivo, contribuindo para falência múltipla de órgãos e morte dos pacientes sépticos (Riedemann et al., 2003; Souto et al., 2011; Sonego et al., 2016).

\subsection{Imunossupressão induzida pela sepse}

Durante a sepse, além de mediadores pró-inflamatórios, o organismo passa a produzir uma variedade de mediadores anti-inflamatórios, dentre eles, receptor solúvel para TNF, receptor solúvel de IL-1ra, inibidores da cascata do complemento, além de citocinas anti-inflamatórias como IL-4, IL-10, IL-13 e transforming growth factor (TGF- $\beta$ ) (Hotchkiss et al., 2003). A mudança para um perfil anti-inflamatório pode levar a um estado de imunossupressão que continua mesmo após a recuperação do quadro séptico, sendo caracterizado pela incapacidade em combater infecções primárias e predisposição em desenvolver uma infecção nosocomial secundária (Cohen, 2002; Hotchkiss et al., 2003; Hotchkiss et al., 2013a).

O quadro de imunossupressão é acompanhado de alterações funcionais das células do sistema imune (Wang et al., 2008). Nesse contexto, monócitos de pacientes sépticos apresentaram capacidade reduzida de montar uma resposta inflamatória, o que também foi demonstrado em modelos animais (Hotchkiss et 
al., 2013a). Essas células deixam de produzir mediadores inflamatórios como TNF e IL-12, passando a secretar mediadores anti-inflamatórios como IL-10 e IL1ra, além de apresentar reduzida expressão do complexo de histocompatibilidade principal II (MHC-II) em sua membrana, prejudicando assim a ativação de linfócitos T e a produção de citocinas inflamatórias (Wang et al., 2008). Já com relação aos neutrófilos, apesar de ainda serem responsivos, sendo encontrados ativados na circulação, eles perdem a capacidade de transmigrar para os tecidos, comprometendo a reposta do organismo contra os microrganismos invasores (Benjamim et al., 2000; Alves-Filho et al., 2006).

A função das células dendríticas também está comprometida em pacientes que sobreviveram à sepse, o que pode ser explicado pela morte excessiva dessas células por apoptose ou por deficiência na sua maturação. Além de uma redução numérica, as células dendríticas também apresentam redução na capacidade de iniciar uma resposta com padrão de citocinas Th1, levando a uma maior produção de citocinas com perfil Th2, o que significa redução da síntese de IL-12 e aumento da síntese de IL-10 (Wang et al., 2008).

Além de monócitos, neutrófilos e células dendríticas, a função dos linfócitos também está prejudicada durante a imunossupressão induzida após a sepse. Estudos com células de humanos e camundongos demonstraram que, essas células entram em um estado de hiporresponsividade e anergia (Cohen, 2002), além de intensa apoptose. (Hotchkiss et al., 2001). Por fim, as alterações induzidas na viabilidade dos linfócitos parecem ser induzidas por mediadores produzidos durante a resposta inflamatória iniciada durante a fase aguda da sepse, uma vez que, o mesmo não foi observado em doentes graves não sépticos (Wang et al., 2008). 
Apesar de representarem uma pequena fração da população total de linfócitos de classe $T$, as células Treg desempenham importante propriedade reguladora sobre a ativação celular (Shevach, 2009). Dentre várias funções, as Tregs secretam citocinas (IL-10, TGF- $\beta$ e IL-35), e vesículas contendo microRNAs que inibem a atividade de linfócitos $T$ efetores e células mielóides, além de competir com linfócitos T pela ligação à citocina IL-2, resultando em apoptose dessas células (Okoye et al., 2014). Quando ativadas, as Tregs podem induzir apoptose de células efetoras de maneira semelhante a células T CD8+ citotóxicas, além de interferir na atividade de outras células do sistema imune por meio de ligantes de membrana, como a galectina-1 e o Cytotoxic $T$ lymphocyte associated antigen 4 (CTLA-4). A galectina-1 pode interagir com receptores nas células $T$, resultando em paralisação do ciclo celular. Já a interação do CTLA-4 com ligantes expressos na superfície das DC, pode modular sua função de reconhecimento e apresentação de antígenos por um mecanismo dependente da expressão da IDO pelas dendríticas (Grohmann et al., 2002; Sharma et al., 2007; Shevach, 2009).

Ainda, já foi demonstrado que as Tregs apresentam importante papel na manutenção do quadro de imunossupressão induzida pela sepse (Wisnoski et al., 2007; Cavassani et al., 2010; Nascimento et al., 2010). Nesse sentido, sabese que existe um aumento na frequência das Tregs no baço de camundongos que sobreviveram à sepse grave, o que foi associado ao desenvolvimento da imunossupressão, uma vez que, camundongos que sobreviveram à sepse foram mais suscetíveis a infecção induzida pela injeção intranasal de Legionella pneumophila. Sendo que, a depleção das Tregs restaurou a capacidade do sistema imune de montar uma resposta antibacteriana eficiente (Nascimento et 
al., 2010). Além disso, camundongos que sobreviveram à sepse apresentaram menor capacidade de controlar o crescimento tumoral após desafio com células tumorais, demonstrando a incapacidade do sistema imune de montar uma resposta antitumoral eficiente (Cavassani et al., 2010; Mota et al., 2016). Por fim, em concordância com resultados encontrados em camundongos, um estudo que avaliou pacientes que morreram em decorrência das complicações desencadeadas pela sepse, apresentaram aumento na frequência das Tregs no baço, além de redução na função de algumas células do sistema imune (Boomer et al., 2011).

Resultados encontrados em nosso laboratório (ainda não publicados) demonstraram que o aumento persistente das Tregs na imunossupressão desenvolvida em animais que sobreviveram à sepse, está relacionado à fatores liberados por macrófagos M2. Existe um aumento na diferenciação deste subtipo de macrófagos durante o desenvolvimento da imunossupressão, o que ocorre na presença das citocinas IL-4, IL-13 e IL-33. Esse achado confere maior importância aos macrófagos M2 na fisiopatologia da doença e abre a perspectiva de estudos com o objetivo de esclarecer a relação entre macrófagos M2 e as Tregs, no contexto da sepse e suas consequências.

Nesse sentido, alguns trabalhos têm estabelecido um papel imunorregulador para a enzima indoleamina 2,3 dioxigenase (IDO), uma vez que, sua ação favoreceu a diferenciação das Tregs, promovendo um estado de tolerância imunológica. Assim, seria interessante investigar o envolvimento da IDO na diferenciação de macrófagos M2 e das Tregs observada em camundongos que sobrevivem a sepse 


\subsection{A enzima indoleamina 2,3 dioxigenase (IDO) no contexto da sepse}

A enzima indoleamina 2,3 dioxigenase (IDO) (EC 1.13.11.42) é constitutivamente expressa em diferentes células e tecidos como hepatócitos, células endoteliais, alguns subtipos de leucócitos e, principalmente, no pulmão e placenta (Shimizu et al., 1978; Taylor et al., 1991; Mezrich et al., 2010). Porém, em condições inflamatórias, como as encontradas durante a sepse, citocinas como IL-1, IL-2, TNF, interferons (IFN)- $\alpha, \beta$ e $\gamma$, bem como LPS e CpG induzem sua expressão em células apresentadoras de antígenos, como as células dendríticas, macrófagos e linfócitos B (Taylor et al., 1991; Puccetti, 2007).

Uma vez expressa, a IDO atua promovendo o metabolismo oxidativo do triptofano, o que pode levar a privação das células deste aminoácido essencial (Taylor et al., 1991). Assim, a redução na disponibilidade deste aminoácido no microambiente limita o crescimento de microrganismos e inibe a proliferação celular, sendo este, o primeiro mecanismo proposto, por meio do qual, a IDO poderia modular a atividade do sistema imune (Edinger et al., 2002; Katz et al., 2008). A ação enzimática da IDO sobre o triptofano, leva a formação da quinurenina, (Takikawa, 2005; Wirthgen et al., 2015), uma molécula que possui importantes propriedades imunomoduladoras (Mezrich et al., 2010; Nguyen et al., 2010). A quinurenina pode ser metabolizada por outras enzimas, dentre elas a kynurenine 3-monooxygenase (KMO), levando a formação de uma série de moléculas metabolicamente ativas e chamadas coletivamente de quinureninas (Diagrama 1). Aproximadamente $95 \%$ do triptofano absorvido na dieta é utilizada pela IDO para alimentar a via metabólica das quinureninas, sendo que, apenas $1 \%$ será utilizada para produção da serotonina que atuará principalmente no sistema nervoso central (Diagrama 1). 
É importante ressaltar que a IDO não é a única enzima capaz de promover a metabolização do triptofano em quinurenina. A enzima L-triptophano 2,3dioxigenase (TDO) (EC 1.13.1.12) é encontrada exclusivamente no fígado, apresenta menor afinidade pelo triptofano quando comparada a IDO, e atua principalmente na manutenção da concentração fisiológica do triptofano. Por outro lado, já foi demonstrado que a TDO também pode atuar modulando o sistema imune (Takikawa, 2005; Bessede et al., 2014; Wirthgen et al., 2015).

Experimentos realizados na década de 70 já apontavam a importância da IDO no contexto da sepse. Yoshida e colaboradores demonstraram que a injeção de LPS na cavidade peritoneal de ratos promoveu um aumento expressivo na atividade da IDO no pulmão dos animais. O que também ocorreu com menor intensidade em outros tecidos como baço, coração e rim. O aumento no pulmão apresentou um pico em $24 \mathrm{~h}$, voltando a valores basais no sexto dia, sugerindo que, com o fim dos estímulos inflamatórios, a atividade da enzima retornaria a valores basais. Com o passar dos anos, outros grupos demonstraram que durante a sepse, existe aumento da expressão da IDO em monócitos isolados do sangue periférico de humanos e camundongos, levando a um aumento da relação kinurenina/triptofano no plasma. Além disso, foi demonstrado que o aumento na razão quinurenina/triptofano pode ser correlacionado com a gravidade da sepse, sendo considerado um mau prognostico para o paciente (Huttunen et al., 2010; Ploder et al., 2010; Tattevin et al., 2010; Darcy et al., 2011; Wirthgen et al., 2015). 


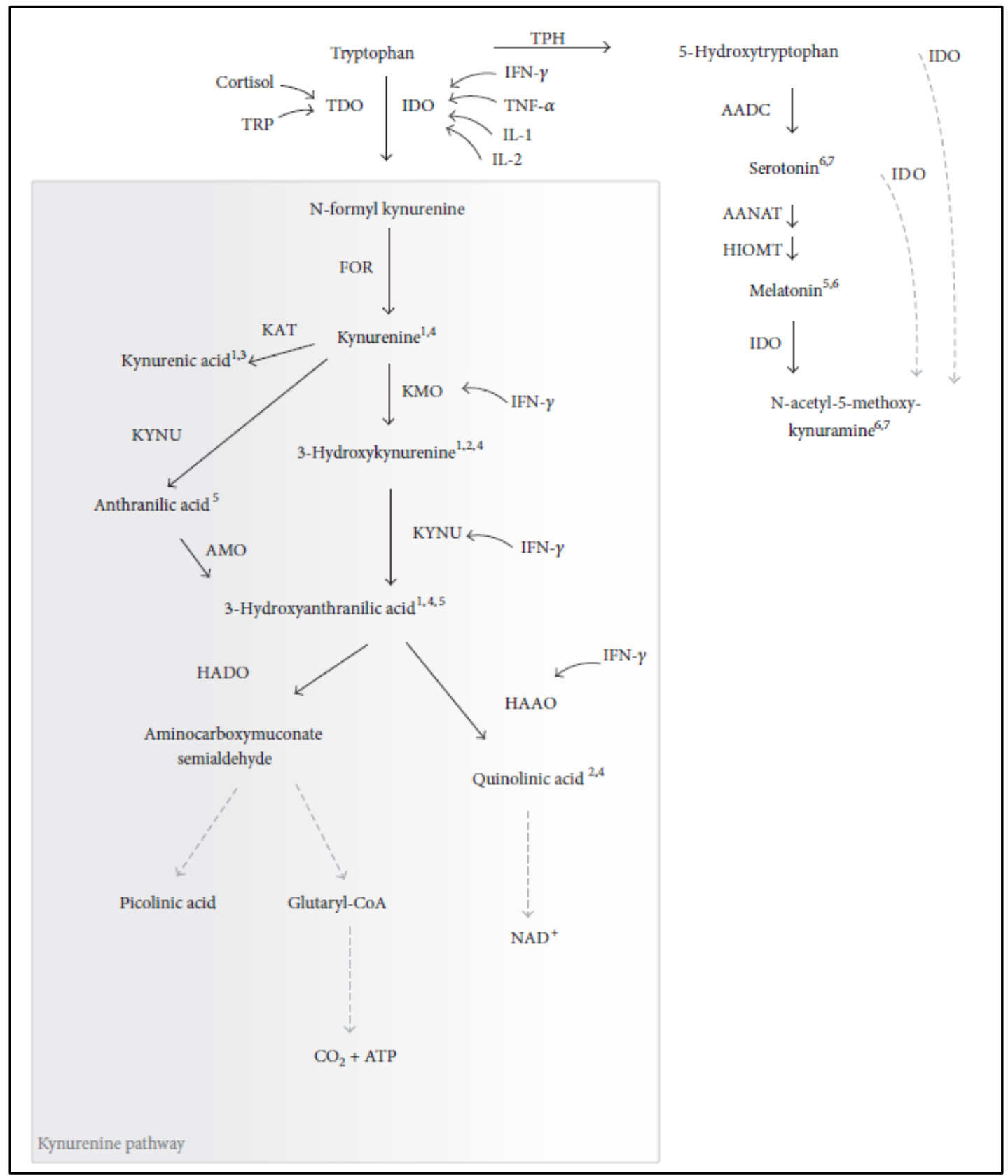

Diagrama 1: Esquema representativo dos metabolitos produzidos a partir da degradação do triptofano: Os números colocados a direita de cada molécula indicam as funções biológicas já descobertas ( 1 imunossupressiva; 2 neurotóxica; 3 neuroprotetora; 4 geração de radicais livres; 5 antioxidante; 6 funções hormonais; 7 modulação do comportamento). Enzimas: FOR=formamidase; IDO=Indoleamine 2,3-dioxygenase; TDO=tryptophan 2,3-dioxygenase; $\mathrm{TPH}=$ tryptophan hydroxylase; $\mathrm{KAT}=$ kynurenine aminotransferase; $\mathrm{KMO}=$ kynurenine 3 monooxygenase; KYNU=kynureninase; $\mathrm{HADO}=3$-hydroxyanthranilic acid dioxygenase; $\mathrm{HAAO}=3$-hydroxyanthranilic acid oxidase; $\quad \mathrm{AMO}=$ anthranilate 3-monooxygenase; $A A D C=$ aromatic $L$-amino acid decarboxylase; $A A N A T=N$-acetyltransferase; $H I O M T=$ hydroxy-Omethyltransferase. Linhas cheias representam que a etapa é catalisada em uma única etapa, linhas pontilhas indica a existência de outras etapas catalíticas. Adaptado de (Wirthgen et al., 2015). 


\subsection{A enzima indoleamina 2,3 dioxigenase (IDO) em um contexto de imunorregulação}

Diante dos dados apresentados até aqui, fica claro que, para um melhor entendimento da sepse e de suas consequências, vários fatores como idade, sexo, doenças previamente adquiridas, foco da infecção primária e tipo de microrganismo causador devem ser levados em consideração. Porém, apesar das inúmeras variáveis, observações feitas em humanos e em camundongos sugerem que o desenvolvimento da imunossupressão depende da intensidade da resposta inflamatória desenvolvida durante a fase aguda da sepse. Ainda, vários trabalhos vêm demonstrando o papel imunorregulador e tolerogênico da IDO em diferentes células do sistema imune, incluindo, a indução de um fenótipo regulador nas DC tolerogênicas e a diferenciação das Tregs. Assim, estudos avaliando o papel modulador da IDO durante a sepse e suas consequências seriam importantes.

A atividade enzimática da IDO possui duas consequências, o consumo do Triptofano e a produção de seu metabolito, a quinurenina. Foi demonstrado que, a redução na disponibilidade de aminoácidos no microambiente promovida pela IDO, é um fator limitante para o crescimento de microrganismos além de promover a inibição da proliferação celular (Taylor et al., 1991; Edinger et al., 2002). Além disso, a depleção de aminoácidos também pode modular o funcionamento do sistema imune indiretamente. Este processo ocorre por meio da ativação ou inibição de sensores intracelulares sensíveis a depleção de nutrientes.

Nesse sentido, foi demonstrado que a redução da concentração de aminoácidos no microambiente celular pode ativar uma quinase denominada 
serina/treonina quinase General Control Nonrepressed 2 (GCN2), levando a diferentes efeitos imunossupressores, dentre eles, a diferenciação e a ativação das Tregs (Fallarino et al., 2006; Sharma et al., 2007). Além disso, a ausência de aminoácidos pode inibir uma importante via imunorreguladora ativada pela molécula Mammalian Target of Rapamycin (mTOR), interferindo na função de células T efetoras e favorecendo a função das Tregs (Powell et al., 2012). Sendo assim, a ativação ou inibição de sensores intracelulares representam uma consequência indireta da ativação da IDO, uma vez que GCN2 e mTOR são sensíveis a mudanças na disponibilidade de aminoácidos no ambiente celular promovidas por ela.

A consequência direta da ação enzimática da IDO sobre o triptofano é a formação da quinurenina. Por sua vez, alguns trabalhos vêm demonstrando que a quinurenina desempenha importante papel na modulação do sistema imune através da ativação do aryl hydrocarbon (AhR). O AhR é encontrado no citoplasma celular, complexado a outras proteínas, podendo ser ativado por uma ampla variedade de moléculas. Após ativação, o complexo se dissocia e o AhR, juntamente com seu ligante, pode permanecer no citoplasma celular, o que é conhecido como via não genômica ou sofrer translocação para o núcleo, o que é conhecido como via genômica. Uma vez no núcleo, o complexo AhR-ligante pode interagir ou não com diferentes fatores de transcrição antes de se ligar ao DNA, promovendo a transcrição de uma ampla variedade de genes (Quintana et al., 2013).

Nesse sentido, foi demonstrado que a ativação de TLR pelo LPS está associado a expressão AhR em DC. Por sua vez, a ativação do AhR irá promover o aumento da expressão da IDO e da IL-10, levando ao desenvolvimento de um 
fenótipo tolerogênico nas DC-IDO+ (Nguyen et al., 2010). Também foi demonstrado que, o tratamento com TGF- $\beta$ promove a expressão do AhR em linfócitos. Sendo que, a ativação do AhR pela quinurenina está envolvido com a diferenciação das Tregs in vitro (Mezrich et al., 2010). Dessa forma, a ativação do AhR é importante para a expressão da IDO em células dendríticas levando a formação da quinurenina. Por outro lado, a quinurenina liberada pelas DC ao se ligar ao AhR expresso nos linfócitos T irá promover a geração de Tregs (Mezrich et al., 2010; Nguyen et al., 2010).

Também foi demonstrado que mediadores encontrados no microambiente tumoral podem induzir a expressão da IDO em DC presentes no linfonodo drenate. As $\mathrm{DC}^{-I D O^{+}}$foram associadas a ativação de Tregs já diferenciadas, bem como, com a diferenciação de linfócitos $T$ naive em novas Tregs. Este elegante mecanismo ilustra como as células tumorais conseguem utilizar a IDO como ferramenta para modular o sistema imune e promover sua expansão (Sharma et al., 2007).

Além da ativação do $A h R$, também foi demonstrado que as vias de sinalização ativadas pelas moléculas CTLA-4 e programmed death-1 (PD-1) são fundamentais para expressão da IDO em DC encontradas no baço. Experimentos in vivo e in vitro demonstraram que a indução da expressão da IDO, após ativação com CpG, não ocorre na ausência de linfócitos T ou após bloqueio farmacológico ou genético das vias mencionadas anteriormente, indicando que a expressão da IDO é modulada por uma complexa rede de sinalização, que depende do ligante, tipo celular e mesmo da condição patológica (Baban et al., 2005; Baban et al., 2011). 


\section{OBJETIVO}

\subsection{Objetivo geral}

Avaliar o papel da IDO no desenvolvimento da imunossupressão induzida pela sepse

\subsection{Objetivos específicos}

2.1.1. Padronização do modelo para avaliar o desenvolvimento da imunossupressão induzida pela sepse.

2.1.2. Determinar a cinética da expressão da IDO no pulmão e baço de camundongos no $1^{\circ}, 3^{\circ}, 7^{\circ}, 10^{\circ}$ e $15^{\circ}$ dia após a indução da sepse.

2.1.3. Determinação da atividade enzimática da IDO no baço e pulmão de camundongos no $1^{\circ}, 3^{\circ}, 7^{\circ}$ e $15^{\circ}$ dias após a sepse.

2.1.4. Avaliar o papel da quinurenina no agravamento da sepse.

2.1.5. Avaliar o papel da IDO no desenvolvimento da imunossupressão induzida pela sepse.

2.1.6. Avaliar o papel da IDO no desenvolvimento de Tregs, no baço, e de macrófagos M2, no lavado peritoneal, de camundongos 15 dias após a indução da sepse.

2.1.7. Avaliar as vias associadas à expressão da IDO em camundongos que sobreviveram à sepse.

2.1.8. Caracterizar a célula responsável pela expressão da IDO no baço de camundongos sobreviventes à sepse. 


\section{MATERIAIS E MÉTODOS}

\subsection{Preparo de soluções}

Solução tamponada fosfatada (PBS) - solução mãe 10X (pH 7,4)

Cloreto de sódio ---

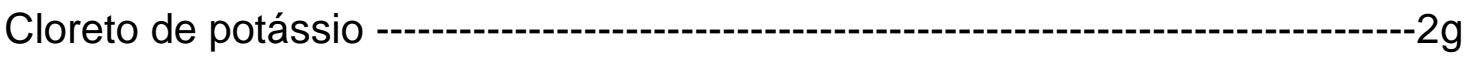

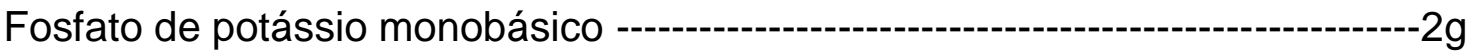

Fosfato de sódio dibásico heptahidratado ----------------------------16,86g

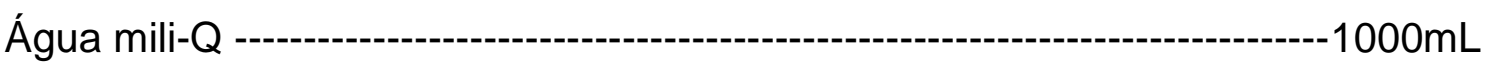

Meio de cultura RPMI (pH 7,4)

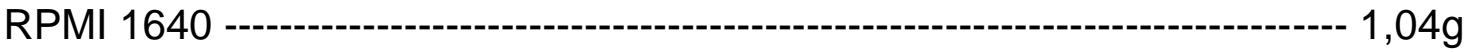

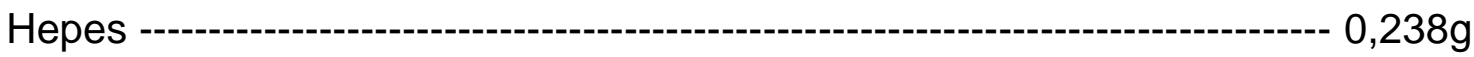

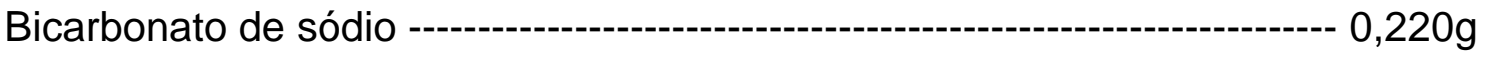

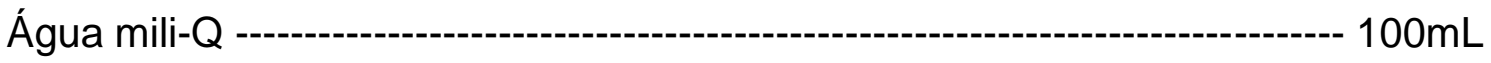

Tampão de Lise a base de Cloreto de amônio $(\mathrm{pH} 7,4)$

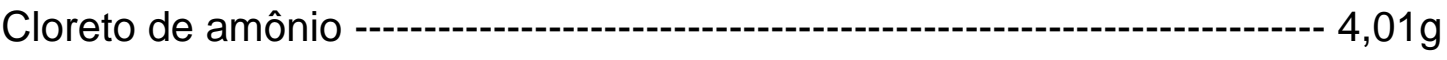

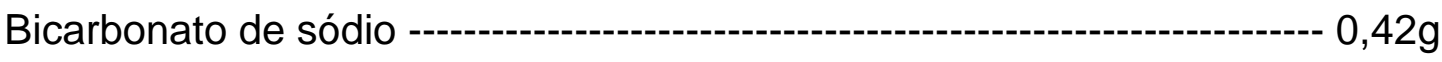

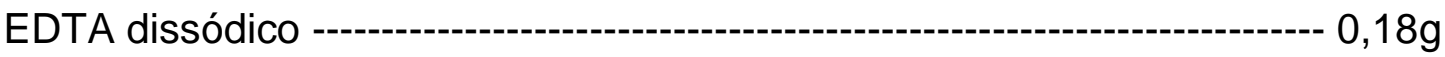

Água mili-Q -

Tampão de FACS

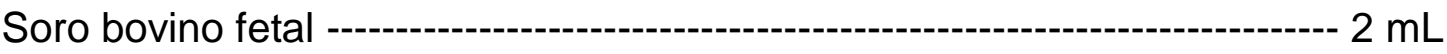

PBS 1X ---.-- 100 mL 
Tampão de fixação

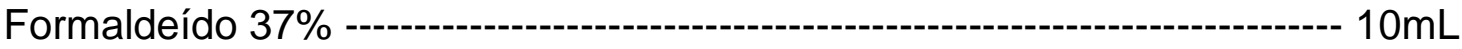

PBS 1X --

Anestésico a base de quetamina e xilazina

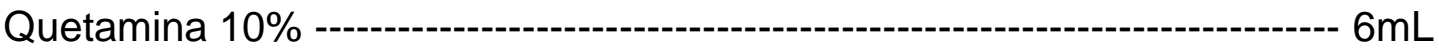

Xilazina 6 \% --- 3,6mL

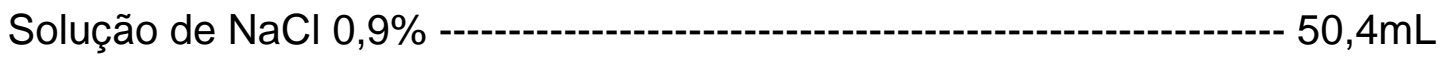

\subsection{Animais experimentais}

Foram utilizados camundongos isogênicos das linhagens C57BL/6 (wild type, WT) além de camundongos deficientes (KO) para IFN-y e AhR da mesma linhagem. Em todos os experimentos os camundongos eram machos, de 6 a 10 semanas pesando entre 18 e $25 \mathrm{~g}$.

Os camundongos WT foram provenientes do Biotério Central da USPRibeirão Preto. Os camundongos IFN-y KO foram provenientes do Biotério de Criação de Animais Especiais da FMRP-USP. Os camundongos AhR KO foram provenientes do Biotério de Criação de Animais Especiais da Universidade de Perugia, Itália. Os animais foram mantidos sob condições de temperatura (23 $25 \stackrel{\circ}{\circ}$ ), ciclos claro/escuro controlados de $12 \mathrm{~h}$ e com livre acesso à ração e água. Todos os procedimentos com animais foram conduzidos de acordo com as normas aprovadas pelo comitê de ética para animais de experimentação da FMRP-USP. 


\subsection{Protocolos experimentais}

\subsubsection{Determinação da taxa de sobrevida de camundongos submetidos a} uma sepse grave e tratados com antibiótico

Para isso, camundongos WT foram submetidos ao procedimento de CLP grave e tratados com antibiótico, conforme descrito no item 3.4. Para indução da sepse em camundongos deficientes para o AhR KO, foi utilizada agulha $22 \mathrm{G}$. O tratamento com antibiótico foi iniciado 6 h após a sepse e na sequência de 12 em $12 \mathrm{~h}$ até o segundo dia. Os camundongos foram mantidos sob condições de temperatura (23 - $\left.25^{\circ} \mathrm{C}\right)$, ciclos claro/escuro de $12 \mathrm{~h}$ e com livre acesso à ração e água. O número de camundongos mortos foi atualizado de 12 em 12 h e utilizado para construção do gráfico de sobrevida.

\subsubsection{Avaliação do papel da quinurenina no agravamento da sepse}

Para isso, camundongos WT foram submetidos ao procedimento de CLP moderada (utilizando agulha 22) $\mathrm{G}$ ou grave (utilizando agulha $18 \mathrm{G}$ ) e tratados com antibiótico, conforme descrito no item 3.4. Um grupo de camundongos submetidos a sepse moderada, foi tratado com quinurenina na dose de 200 $\mathrm{mg} / \mathrm{Kg}$, conforme esquema abaixo. A mortalidade foi acompanhada conforme item 3.3.1. Foram utilizados os grupos experimentais:

- WT CLP grave + sal - WT CLP moderada + sal -WT CLP moderada + Kyn 


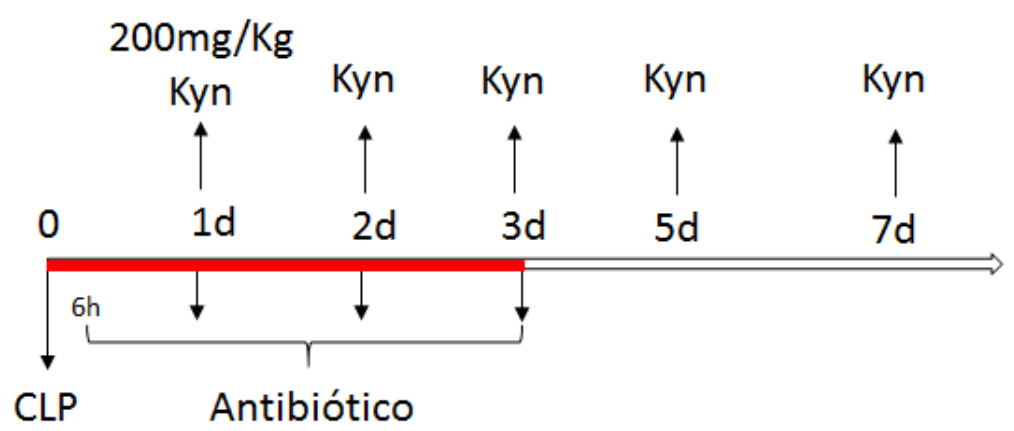

\subsubsection{Determinação da cinética de expressão proteica e da produção de citocinas}

Camundongos WT ou KO foram submetidos ao procedimento de CLP grave e tratados com antibiótico, conforme descrito no item 3.4. Nos dias 1, 3, 7, 10 e 15 após a CLP, os animais foram eutanasiados e pulmão e baço coletados para quantificação da expressão proteica da IDO, KMO e AhR, por meio da técnica de WB, descrita no item 3.8. O pulmão dos camundongos também foi utilizado para avaliar a produção das citocinas IL-4, IL-10, IL-13 e IL-33, por meio do ensaio imunoensimático ELISA, conforme descrito no item 3.6. Foram utilizados os grupos experimentais:

- WT ou KO naive

- WT ou KO CLP

\subsubsection{Avaliação do papel da IDO no desenvolvimento de macrófagos M2 e}

\section{Tregs}

Para isso, camundongos WT foram submetidos ao procedimento de CLP grave e tratados com antibiótico, conforme descrito no item 3.4. No $4^{\circ}$ dia após a CLP os animais foram tratados com um inibidor competitivo da enzima denominado 1-metil-DL-triptofano (DL-1MT). Estudos preliminares demostraram que esse composto apresenta meia vida de eliminação de $6 \mathrm{~h}$ em ratos, quando administrado pela via oral, sendo que, administração durante 28 dias não 
apresentou toxicidade (Jia et al., 2008). Para a realização do presente estudo camundongos foram tratados com DL-1MT na dose de $3 \mathrm{mg} /$ camundongo, de 12 em $12 \mathrm{~h}$, durante 10 dias, pela via intraperitoneal. No $15^{\circ}$ dia após a CLP, o número de macrófagos M2 foi avaliado no lavado peritoneal e o de Tregs no baço dos animais por meio da técnica de citometria de fluxo descrita no item 3.9. Foram utilizados os grupos experimentais:

- WT naive + veículo $\quad$ - WT CLP + veículo $\quad$ - WT CLP + DL-1MT

\subsubsection{Avaliação do papel da IDO no desenvolvimento da imunossupressão induzida pela sepse}

Para isso, camundongos WT foram submetidos ao procedimento de CLP grave e tratados com antibiótico, conforme descrito no item 3.4. No $4^{\circ}$ dia após a CLP os animais foram tratados com DL-1MT. Para a realização do presente trabalho, camundongos foram tratados durante 10 dias com DL-1MT, na dose de $3 \mathrm{mg} /$ camundongo, de $12 \mathrm{em} 12 \mathrm{~h}$, pela via intraperitoneal. No 15ํㅡ dia após a CLP, os camundongos foram desafiados com $5 \times 10^{4}$ células do Melanona B16F10 expressando luciferase, conforme descrito no item 3.5. Após o desafio, o crescimento tumoral foi avaliado diariamente, por meio de medida direta utilizando um paquímetro, ou no $6^{\circ}$ e $11^{\circ}$ dia após a inoculação, por meio da mensuração da bioluminescência, conforme descrito no item 3.5. No $11^{\circ}$ dia após desafio com células tumorais (dpd) o baço foi coletado para avaliação da frequência das células MDSC. No $14^{\circ} \mathrm{dpd}$ o linfonodo drenante da região tumoral foi coletado e utilizado para avaliação da frequência de células CD8+ produtoras de IFN-y. A frequência das células MDSC e CD8+ IFN-Y foi avaliada por meio da técnica de citometria de fluxo descrita no item 3.9. 


\subsubsection{Avaliação do papel do IFN - y na regulação da expressão proteica da IDO}

Camundongos WT ou deficientes para IFN - y foram submetidos ao procedimento de CLP grave e tratados com antibiótico, conforme descrito no item 3.4. Os camundongos foram eutanasiados para coleta do baço no $15^{\circ}$ dia após a CLP. Os tecidos coletados foram utilizados para a quantificação da expressão proteica da IDO por meio da técnica de WB ou para avaliação da frequência das Tregs, descritas nos itens 3.8. e 3.9. Foram utilizados os grupos experimentais:

- WT naive

- WT CLP

- KO naive

- KO CLP

\subsubsection{Avaliação do papel do AhR na regulação da expressão proteica da IDO}

Camundongos WT e deficientes para o AhR foram submetidos ao procedimento de CLP utilizando agulha $22 \mathrm{G}$. A primeira dose do antibiótico foi dada $6 \mathrm{~h}$ após a CLP e na sequência de $12 \mathrm{em} 12 \mathrm{~h}$ até $02^{\circ}$ dia. No $8^{\circ}$ dia após a CLP, os camundongos foram eutanasiados para coleta do baço. O baço total foi utilizado para avaliar a expressão proteica da IDO ou do AhR por meio da técnica de WB. Em um segundo experimento, $2,5 \times 10^{6}$ células do baço foram estimuladas com LPS $(0,5 \mu \mathrm{g} / \mathrm{ml})$ ou CPG $(2,5 \mu \mathrm{g} / \mathrm{ml})$ em placas de 48 wells a $37^{\circ} \mathrm{C}, 95 \%$ de $\mathrm{O} 2$ e $5 \%$ de $\mathrm{CO} 2$. As células foram recuperadas $24 \mathrm{~h}$ após o início da cultura e utilizadas para avaliação da expressão proteica da IDO e do AhR por meio da técnica de WB. Por fim, em alguns experimentos o linfonodo mesentérico foi coletado no $8^{\circ}$ dia após a CLP e utilizado para avaliação da 
frequência das Tregs descrita no item 3.9. Foram utilizados os grupos experimentais:

- WT naive

- WT CLP

$-\mathrm{KO}$ CLP

\subsection{Modelo experimental de imunossupressão induzida pela sepse}

Foi utilizado o modelo experimental de sepse grave induzida pela ligadura $\mathrm{e}$ perfuração do ceco (CLP), originalmente descrito por Baker et al. (1983), com modificações (Nascimento et al., 2010). Resumidamente, os animais foram anestesiados com quetamina $10 \%$ e xilazina $6 \%$ i.p. na dose de $10 \mu \mathrm{L} / \mathrm{g}$. É importante ressaltar que este procedimento está de acordo com os Princípios Éticos na Experimentação Animal, e foi aprovado pela Comissão de Ética em Experimentação Animal da Faculdade de Medicina de Ribeirão Preto ( $\mathrm{n}^{\circ}$ 10/2014). Em seguida, os camundongos sofreram laparotomia, o ceco foi exposto e ligado com um fio de algodão abaixo da válvula íleo-cecal, seguido de perfuração transversal com agulha $18 \mathrm{G}$ estéril. $\mathrm{O}$ ceco foi pressionado para a saída de fezes pela perfuração e recolocado no abdômen, sendo a incisão suturada. Logo após, os camundongos receberam injeção subcutânea de salina (1 ml) e foram mantidos sob aquecimento com auxílio de uma lâmpada incandescente até o término do efeito do anestésico. Os camundongos foram tratados com antibiótico ertapenem sódico i.p. na dose de $30 \mathrm{mg} / \mathrm{Kg}, 6 \mathrm{~h}$ após a cirurgia (dia 0) e posteriormente em intervalos de $12 \mathrm{~h}$ até o terceiro dia, com o objetivo de aumentar a sobrevida dos animais operados (Nascimento et al., 2010).

Os camundongos foram eutanasiados em diferentes dias após a CLP para a coleta de tecido e células. Em alguns experimentos, no 15ํํㅁ após a CLP, os 
camundongos foram desafiados com células do melanoma B16-F10, conforme descrito no item 3.3.5. Em estudos prévios realizados em nosso laboratório, foi demonstrado que, pelo menos em protocolos envolvendo o procedimento de CLP, não há diferença na resposta inflamatória e imune entre camundongos naive e falso operados (sham) (Nascimento et al., 2010). Sendo assim, no presente projeto serão utilizados como controle do procedimento de CLP somente camundongos naive.

\subsection{Desafio com células tumorais}

A linhagem de melanoma B16-F10 transfectadas com o gene da luciferase foi utilizada para avaliar o grau de imunossupressão em camundongos sobreviventes à sepse grave. As células do melanoma estavam armazenadas em nitrogênio líquido e para realização do experimento, foram expandidas em cultura contendo meio RPMI 1640, soro bovino fetal (10\%), glutamina (2 mM), anfotericina $B(250 \mu \mathrm{g} / \mathrm{mL})$ e penicilina + streptomicina $(100 \mu \mathrm{g} / \mathrm{mL})$. As células foram mantidas a $37^{\circ} \mathrm{C}, 95 \%$ de $\mathrm{O} 2$ e $5 \%$ de $\mathrm{CO} 2$ até que a confluência na garrafa de cultura fosse próxima de $50 \%$. No $15^{\circ}$ após a CLP, $5 \times 10^{4}$ células do melanoma foram inoculadas em um volume de $200 \mu \mathrm{L}$ de salina no flanco direito dos camundongos que sobreviveram à sepse ou animais naive.

O crescimento tumoral foi avaliado por meio de medida direta empregando um paquímetro ou pela mensuração da bioluminescência. Para realização da medida direta, o crescimento tumoral foi acompanhado até que fosse possível a utilização do paquímetro, o que aconteceu no $9^{\circ}$ dia após o desafio com as

células tumorais. A partir de então, foram realizadas medidas diárias até a eutanásia dos camundongos. Os valores obtidos foram utilizados para calcular 
o volume tumoral por meio da fórmula: $\pi x$ eixo maior $x$ eixo menor $x$ eixo menor/6 (Overwijk et al., 2001).

As células de melanoma utilizadas para realização do experimento expressam a enzima luciferase, o que permitiu a mensuração do volume tumoral pela medida da captação da bioluminescência emitida. Para isso, no $6^{\circ}$ ou no $11^{\circ}$ dia após o desafio com as células tumorais (dpd), os camundongos receberam injeção intraperitoneal de luciferina $(150 \mathrm{mg} / \mathrm{Kg})$ e a bioluminescência foi captada com auxílio do sistema IVIS Spectrum.

Em alguns experimentos no $11^{\circ}$ o baço foi coletado para avaliar a frequência das myeloid-derived suppressor cells (MDSC). No $14^{\circ} \mathrm{dpd}$, antes do período com maior taxa de crescimento tumoral, no qual é comum o aparecimento de necrose na região central da massa tumoral, o linfonodo drenante foi retirado para avaliação da frequência de células $\mathrm{CD}^{+}$produtoras de IFN- $\mathrm{y}$, por meio da técnica de citometria de fluxo, conforme descrito no item 3.9.

\subsection{Quantificação de citocinas}

A concentração das citocinas foi mensurada no pulmão por meio do ensaio imunoenzimático (ELISA), utilizando kits comerciais da R\&D e BD, conforme as recomendações dos fabricantes para cada kit. Para coleta das amostras, camundongos que sobreviveram à CLP foram anestesiados e perfundidos com $20 \mathrm{~mL}$ de salina. O lobo pulmonar inferior esquerdo foi coletado, imerso em 300 $\mu \mathrm{L}$ de solução PBS + EDTA $1 \mathrm{mM}$ e armazenado a $-70^{\circ} \mathrm{C}$. No dia da dosagem o pulmão foi macerado com auxílio de um homogeneizador de tecido (Polytron®, Polytrom PT 3100 , USA) e centrifugado a $1300 \times$ G durante 15 minutos a $4{ }^{\circ} \mathrm{C}$. Em seguida, o sobrenadante foi recuperado e utilizado para realização das 
análises seguindo as recomendações indicadas pelo fabricante (Alves-Filho et al., 2006) .

\subsection{Avaliação da expressão gênica da IDO do AhR e da KMO por real time- RT PCR}

Para os experimentos em que a expressão gênica da IDO e do AhR foram avaliadas, o baço dos camundongos foi coletado no $8^{\circ}$ dia após a CLP. As populações de células CD11 $\mathrm{c}^{+}$e CD11c- foram isoladas com auxílio de beads magnéticas (Miltenyi Biotec) e utilizadas para realização do ensaio. Para os experimentos em que a expressão gênica da $\mathrm{KMO}$ foi avaliada, camundongos foram submetidos à CLP grave e amostras do baço coletadas no $1^{\circ}, 3^{\circ}, 7^{\circ}, 10^{\circ}$ e $15^{\circ}$ após a CLP. Após a coleta, todas as mostram foram estocadas a $-70{ }^{\circ} \mathrm{C}$, em $250 \mu \mathrm{L}$ de reagente Trizol® (Ambion - Invitrogem Corporation, Van Allen Way, Carlsbad, USA). No dia da dosagem, as amostras de baço foram homogeneizadas com auxílio de um homogeneizador de tecidos (Homogeneizer Workcenter, IKA T 10 basic ultra-turrax) antes da extração do RNA total utilizando clorofórmio (Merck). A concentração do RNA foi determinada através da densidade ótica no comprimento de onda de $260 \mathrm{~nm}$, com auxílio do aparelho nanoVue plus GE®.

Para a transcrição do cDNA, foram utilizados $2 \mu \mathrm{g}$ de amostra de RNAm, 1 $\mu \mathrm{L}$ de Oligo DT $(0,5 \mu \mathrm{g} / \mu \mathrm{L}$ - Sigma) e água q.s.p $7 \mu \mathrm{L}$. Em seguida a solução foi levada a um termociclador (Eppendorf mastercycle gradiente), seguindo um protocolo de variação de temperatura padronizado.

Para realização da reação quantitativa do RT-PCR em tempo real foi utilizado o sistema ABI Prism 7500 Sequence Detection System, com o sistema de 
fluorescência SYBR-green ${ }^{\circledR}$ (Invitrogen, Carlsbad, USA). Os resultados encontrados foram normalizados pela expressão do GAPDH. As análises foram realizadas através do método comparativo de "cycle threshold" (CT). Foram utilizadas as sequências:

ido1 ( $\mathrm{F}=5$ '-TCT GCC TGT GCT GAT TGA - 3') e (R=5'- CTG TAA CCT GTG TCC TCT CA - 3');

AhR (F=5'- CCA CTG ACG GAT GAA GAA GGA - 3') e (R=5'- ATC TCG TAC AAC ACA GCC TCT C - 3');

KMO (F=5'-GCA CCT TCGC ATT GGC AT-3') e (R=5'TGT GCC CAT GAA AGC CAG-3');

Gapdh (F=5'-GCC TTC CGT GTT CCT ACC C-3') e (R=5'-CAG TGG GCC CTC AGA TGC-3').

\subsection{Avaliação da expressão proteica por Western Blotting}

Para isso, os camundongos foram submetidos à CLP grave e eutanasiados em dias predeterminados, conforme descrito no item 3.3.3. Amostras do baço e pulmão foram coletadas e imediatamente colocadas em nitrogênio líquido, sendo em seguida, armazenadas a - $70 \stackrel{\circ}{\circ}$. No dia do experimento as amostras foram processadas com homogeneizador de tecidos (Dremel 10.8 V Lithium-íon), em solução contendo tampão RIPA Buffer® (Sigma Aldrich) com inibidor de protease. Em seguida, as amostras foram utilizadas para dosagem de proteínas pelo método colorimétrico, empregando o reagente Bradford Reagent (Sigma Aldrich).

Volumes contendo quantidades específicas de proteína foram incubados com tampão de amostras na proporção de $1: 1$, a $95{ }^{\circ} \mathrm{C}$ durante $10 \mathrm{~min}$. Em 
seguida, amostras do homogeneizado foram separadas por eletroforese em gel acrilamida SDS-PAGE de 10\% (IDO e Ahr) ou 12\% (KMO) e transferidas para membranas de nitrocelulose. Após a transferência, as membranas foram incubadas a $4^{\circ} \mathrm{C}$ com tampão de bloqueio, contendo PBS e leite em diferentes concentrações $(p / v)$ além de Tween $20(0,1 \%)$. Em seguida, as membranas foram lavadas com PBS e Tween 20 (0,1\%) e incubadas em solução de PBS e Tween $20(0,1 \%)$ contendo anticorpo monoclonal para IDO, AhR e KMO (Santa Cruz Biotechnology, Inc; Cell Signaling Technology) ou (Abcam plc, Cambridge Science Park in Cambridge, UK). Em seguida, as membranas foram novamente lavadas, incubadas por $2 \mathrm{~h}$ com anticorpo secundário e novamente lavadas. Finalmente, as membranas foram reveladas com o kit de quimioluminescência (ECL, Amershan Pharmacia Biotech, Little Chalfont, U.K.), seguindo as recomendações do fabricante. Para o padrão de proteínas utilizado, o peso estimado para a enzima IDO é de $42 \mathrm{KDa}$, para $\mathrm{KMO}$ é de $58 \mathrm{KDa}$, para Ahr de $96 \mathrm{KDa}$.

\subsection{Citometria de fluxo}

Para análise das diferentes populações celulares foram utilizados o baço, linfonodo e células do lavado peritoneal. As marcações $\mathrm{F} 4 / \mathrm{F} 80^{+}$e receptor de manose $\left(\mathrm{MR}^{+}\right)$foram utilizadas para identificar a população celular de macrófagos M2 no lavado peritoneal. As marcações $\mathrm{CD}^{+}$e $\mathrm{Foxp}^{+}$foram utilizadas para identificação das Tregs no baço. As marcações CD8 ${ }^{+}$e IFN- $\gamma^{+}$ foram utilizadas para identificação de células $\mathrm{CD}^{+}$produtoras de IFN-ץ no linfonodo drenante tumoral. Por fim, para marcação das Myeloid-derived suppressor cells (MDSCs) do baço, foram utilizados os marcadores CD11 $\mathrm{b}^{+}$ 


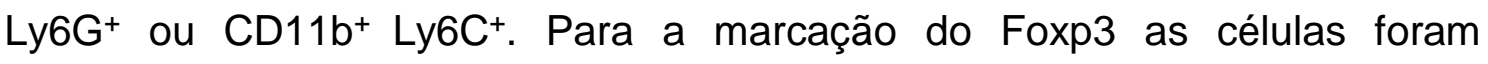
permeabilizadas utilizado um Kit específico (ebioscience). Para avaliar a produção de IFN- $\gamma$, células $\mathrm{CD}^{+}$foram coletadas do linfonodo drenante, estimuladas por $4 \mathrm{~h}$ com phorbol 12-myristate 13-acetate (PMA) e lonomicina, a $37^{\circ} \mathrm{C}, 95 \%$ de $\mathrm{O} 2$ e $5 \%$ de $\mathrm{CO} 2$. Em seguida, foi realizada permeabilização utilizando o mesmo Kit citado anteriormente. Após a marcação, todas as amostras foram analisadas por FACSCanto e os dados interpretados pelo software FCS Express V3.

\subsection{Quantificação dos níveis de quinurenina no soro}

Os experimentos para quantificação dos níveis de quinurenina no soro foram realizados em colaboração com a Professora Francesca Fallarino da Università Degli Studi Di Perugia. Para isso, camundongos C57BL/6 foram submetidos à CLP, conforme descrito no item 3.3.7 (moderada) ou 3.4 (grave). O soro foi coletado no $3^{\circ}$ dia após a cirurgia, congelado em nitrogênio líquido e posteriormente, armazenado à - $70{ }^{\circ} \mathrm{C}$ até o dia da realização da dosagem. No dia do teste, $100 \mu \mathrm{L}$ do soro foi diluído em volume igual de $30 \mathrm{mM}$ acetato de sódio ( $\mathrm{NaAc}$ ) pH 4.0, permanecendo a temperatura ambiente por 2 minutos. $\mathrm{Na}$ sequência, $50 \mu \mathrm{L}$ de ácido tricloroacético (TCA) a $30 \%$ foi adicionado e homogeneizado imediatamente. As amostras foram incubadas em gelo por 5 minutos e em seguida centrifugadas à $10000 \times$ G. O sobrenadante foi utilizado para realização da Cromatografia Líquida de Alta Eficiência (HPLC) (Liu et al., 2014). 


\subsection{Ensaio para avaliação da atividade enzimática da IDO}

Os experimentos para avaliação da atividade enzimática da IDO foram realizados no laboratório do Professor Andrew L. Mellor da Georgia Health Sciences University. Para isso, camundongos C57BL/6 foram submetidos à CLP, conforme descrito no item 3.4 . No $1^{\circ}, 7^{\circ}$ e $15^{\circ}$ dia após a cirurgia foi realizada a coleta do pulmão e do baço. Imediatamente após a coleta, os tecidos foram congelados em nitrogênio líquido e armazenados à $-70{ }^{\circ} \mathrm{C}$ até 0 dia da realização da dosagem. O ensaio da atividade enzimática foi realizado de acordo com Huang 2013 (Hoshi et al., 2010). Resumidamente, uma concentração de $100 \mathrm{mg} / \mathrm{mL}$ de tecido foi homogeneizada em solução contendo $100 \mathrm{mM}$ de tampão fosfato de potássio $\mathrm{pH}$ 6.5, $50 \mu \mathrm{M}$ de azul de metileno, $50 \mathrm{mM}$ ascorbato de sódio, $0.4 \mathrm{mM}$ L-triptofano e $20 \mu \mathrm{g}$ de catalase. A solução foi incubada por 2 horas a $37{ }^{\circ} \mathrm{C}$ a $550 \mathrm{rpm}$ usando um thermomixer. Ao final da incubação foi adicionado $25 \mu \mathrm{L}$ de ácido tricloroacético (TCA) 30\%, as amostras foram homogeneizadas e colocadas em gelo por 5 minutos. É importante ressaltar que, para obter o tempo $0,25 \mu \mathrm{L}$ de TCA $30 \%$ foi adicionado nas amostras sem o intervalo de incubação de $2 \mathrm{~h}$. Na sequência as amostras foram centrifugadas e o sobrenadante foi analisado por HPLC. A atividade enzimática foi expressa em $\mathrm{pmol} / \mathrm{hora} / \mathrm{mg}$ de tecido de acordo com a formula abaixo.

Atividade $=([K y n]$ após $2 \mathrm{~h}(\mathrm{em} \mu \mathrm{M})-[\mathrm{Kyn}]$ na $0 \mathrm{~h}) \times 2400 /(2 \mathrm{~h} \times$ concentração de tecido $)$

\subsection{Ensaio de Imunofluorescência}

Para isso, os camundongos foram submetidos à CLP, conforme descrito no item 3.4. No $15^{\circ}$ dia após a cirurgia os camundongos foram perfundidos com paraformaldeído (PFA) a $4 \%$. Em seguida, o baço foi coletado e mantido em 
tubo plástico contendo PFA (4\%) por 12 h. Após esse período, o tecido foi colocado em um tudo com sacarose a $30 \%$ por 48 h, incluído em gel TissueTek $^{\circledR}$ (Optimal Cutting Compound - OCT) e armazenadas a $-70{ }^{\circ} \mathrm{C}$. Para preparação das lâminas, fatias de $5 \mu \mathrm{m}$ de espessura foram cortadas com auxílio de um Criostato. Para marcação, os cortes foram fixados nas lâminas em uma câmara de vácuo ( $80 \mathrm{Kpa}$ ) em 2 ciclos de 5 minutos e um terceiro ciclo de 60 minutos, seguido de um banho de 10 minutos em metanol gelado $\left(-20^{\circ} \mathrm{C}\right) . \mathrm{Na}$ sequência, as lâminas foram lavadas com PBS em 2 ciclos de 5 minutos. A preparação foi incubada em uma solução de glicina $0,1 \mathrm{M}$ por 30 minutos, seguido de nova incubação em solução A [PBS + BSA (3\%) e Triton X 100 $(0,2 \%)]$ também por 30 minutos. Na sequência uma nova incubação de 30 minutos foi feita com a solução B (solução A diluída por um fator de diluição 2). Finalmente, o anticorpo primário foi diluído na solução B e adicionado sobre a preparação. O sistema foi colocado em geladeira durante $12 \mathrm{~h}$ (overnight), e o anticorpo lavado com PBS em 5 ciclos de 5 minutos.

O anticorpo secundário foi diluído em BSA (5\%) e adicionado sobre o sistema. Após um período de incubação de $1 \mathrm{~h}$ à temperatura ambiente, as lâminas foram lavadas com PBS em 5 ciclos de 5 minutos seguido de 1 ciclo de 5 minutos com água MilliQ. Por fim, a preparação foi selada com auxílio de lamínulas e um reagente específico contendo DAPI (Prolong®) ou não (Fluor save Reagent®). As imagens foram produzidas com auxílio de um microscópio confocal Leica TCS SP5. Foram utilizados os seguintes anticorpos para realização dos ensaios: CD45/B220 Alexa Fluor 488 (Cat \# 103225), CD11c Alexa Fluor 647 (Cat \# 117312), CD4 Brilliant Violet 421 (Cat \# 100443). Para 
marcação da enzima IDO foram utilizados o anticorpo primário anti-IDO 1 (sc365086) e o anticorpo secundário Alexa Fluor 594 (A21203).

\subsection{Ensaio de co-cultura}

Camundongos C57BL/6 WT foram submetidos à CLP grave, conforme descrito no item 3.4. No $8^{\circ}$ dia após a cirurgia, foi realizado um procedimento para facilitar a liberação das DC. Para isso, o baço foi mantido em incubação com solução de colagenase $100 \mathrm{U} / \mathrm{mL}$ diluída em RPMI incompleto. Na sequência, o baço foi colocado em solução de colagenase $400 \mathrm{U} / \mathrm{mL}$ e mantido em estufa a $37^{\circ} \mathrm{C}, 95 \%$ de $\mathrm{O} 2$ e $5 \%$ de $\mathrm{CO} 2$ durante 30 minutos. Após incubação, o tecido foi macerado e filtrado em peneira de $40 \mu \mathrm{m}$. Na sequência, as células foram centrifugadas ( $400 \mathrm{G}, 10 \mathrm{~min}, 4^{\circ} \mathrm{C}$ ), e recuperadas em RPMI completo. Após contagem, as células $\mathrm{CD}_{11 \mathrm{C}^{+}}$foram isoladas com auxílio de Beads magnéticas (Miltenyi Biotec), conforme orientação do fabricante. Frações de células $\mathrm{CD} 11 \mathrm{c}^{+}$provenientes do baço de camundongos WT e naive foram cultivadas com células CD4+ ${ }^{+}$CD25 provenientes do baço e linfonodos de camundongos naive. Para o ensaio, foi utilizada uma proporção de 1 célula apresentadora $\left(\mathrm{CD} 11 \mathrm{C}^{+}\right)$para 3 respondedoras $\left(\mathrm{CD} 4^{+}\right)$, em placa de 48 wells, com anti-CD3 e anti-CD28 e um volume final de $400 \mu \mathrm{L}$. As células foram mantidas em estufa a $37^{\circ} \mathrm{C}, 95 \%$ de $\mathrm{O} 2$ e $5 \%$ de $\mathrm{CO} 2$, durante 4 dias. Após incubação as células foram recuperadas e marcadas com anti-CD4, anti-FOXP3, conforme descrito no item 3.9. 


\subsection{Análise Estatística}

Nos casos de diferentes tratamentos ou grupos, o teste de análise de variância (ANOVA) foi utilizado para comparar as alterações entre eles. Em todos os casos, comparações individuais foram testadas com teste t de Bonferroni (comparações múltiplas) ou teste $\mathrm{t}$ de Student (comparações entre duas amostras) para amostras não pareadas. As razões de sobrevida foram expressas como porcentagem de animais vivos e a diferença entre elas obtida pelo teste Chi-Quadrado. Para todos os testes, foram considerados estatisticamente diferentes valores de $p<0,05$. 


\section{RESULTADOS}

\subsection{Avaliação do desenvolvimento da imunossupressão induzida após a} sepse

Estudos tem demonstrado que pacientes e camundongos, que sobrevivem a sepse, desenvolvem um quadro de imunossupressão evidenciado pela redução na capacidade de montar uma resposta imunológica eficiente contra infecções secundárias ou mesmo controlar o crescimento tumoral. Ainda, sabe-se que esta imunodisfunção está associada ao aumento do número e atividade das Treg. (Cavassani et al., 2010; Nascimento et al., 2010; Mota et al., 2016). Assim, o objetivo geral deste trabalho foi avaliar os mecanismos associados ao aumento na frequência das Tregs observado em camundongos que sobreviveram a uma sepse grave. É importante ressaltar que, existe uma relação direta entre a gravidade da sepse e o desenvolvimento de um quadro de imunossupressão (Hotchkiss et al., 2013a).

Assim, camundongos foram submetidos a uma sepse grave induzida pelo modelo de ligadura e perfuração do cécum (cecal ligation and puncture-CLP), conforme descrito em detalhes no item 3.4. Por se tratar de um modelo de sepse grave, $100 \%$ dos animais morrem em até 3 dias após a indução da CLP. Assim, para aumentar a taxa de sobrevida, os camundongos receberam reposição de fluido imediatamente após a CLP e antibioticoterapia a partir da sexta hora após a cirurgia, e de 12 em 12 h até o terceiro dia. A administração de suporte hídrico associado a antibioticoterapia promoveu uma taxa de sobrevida de aproximadamente $50 \%$. Os camundongos que sobreviveram foram utilizados para a realização deste trabalho (Figura $1 \mathbf{A}$ ). 
Já foi demonstrado que camundongos que sobrevivem à sepse desenvolvem um quadro de imunossupressão caracterizado pela redução na capacidade de montar uma resposta antitumoral eficiente (Cavassani et al., 2010; Mota et al., 2016). Assim, neste trabalho, foi utilizado como ferramenta a linhagem de células de melanoma B16-F10 expressando luciferase, com o objetivo de avaliar se os camundongos que sobreviveram à sepse desenvolveram imunossupressão. Resumidamente, 15 dias após a indução da sepse, camundongos foram desafiados com células tumorais, conforme descrito no item 3.5. No $11^{\circ}$ dia após o desafio com as células de Melanoma (dpd), o crescimento tumoral foi avaliado pela captação de bioluminescência com auxílio do sistema IVIS. Para isso, os animais foram tratados com luciferina, substrato para a enzima luciferase. Assim, quando maior a massa tumoral maior seria a quantidade de bioluminescência emitida. Os resultados demonstraram um maior crescimento tumoral nos camundongos que sobreviveram à sepse em relação aos camundongos naive (Figura $1 \mathrm{~B}$ ).

Além da bioluminescência, o volume tumoral foi avaliado diariamente a partir do $9^{\circ} \mathrm{dpd}$ com auxílio de um paquímetro. A análise dos resultados confirmou as observações realizadas com o auxílio do sistema IVIS, revelando um aumento no volume tumoral nos camundongos que sobreviveram à sepse (Figura 1 C). Assim, os resultados demonstram que camundongos que sobreviveram a sepse grave desenvolveram um quadro de imunossupressão. 


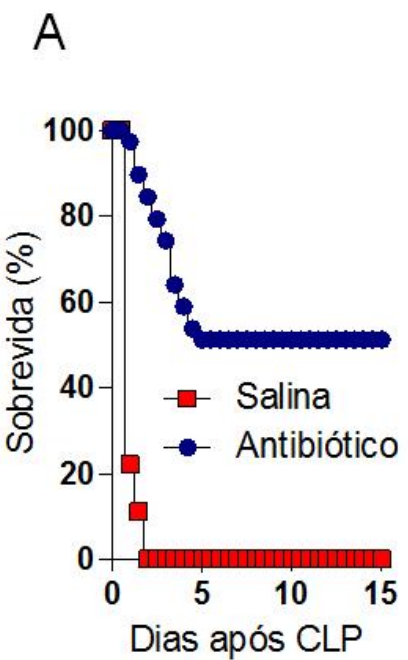

B

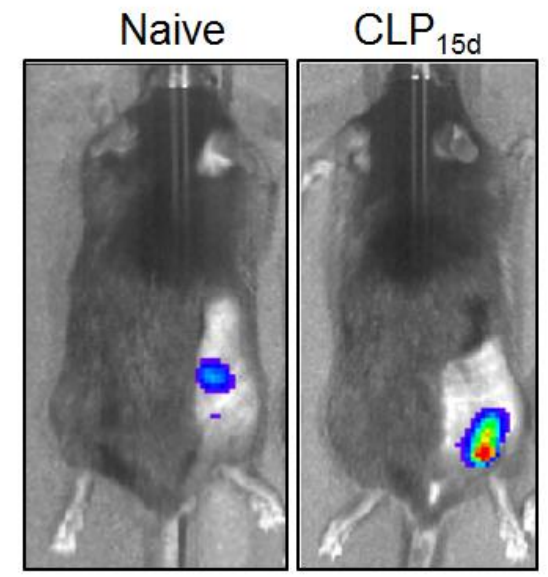

C

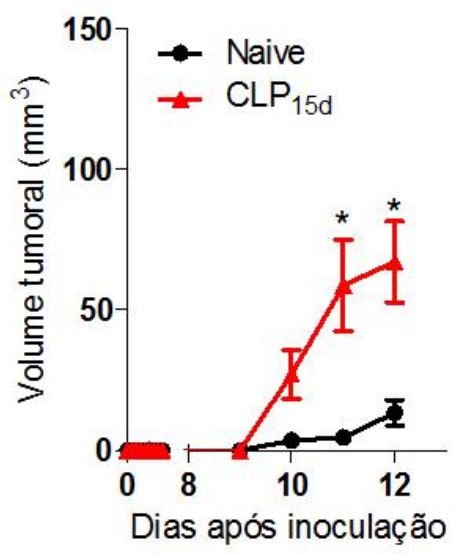

Figura 1: Avaliação do crescimento tumoral em camundongos sobreviventes à sepse. Camundongos C57BL/6 foram submetidos à CLP e tratados com antibiótico. No $15^{\circ}$ dia após CLP, os camundongos foram desafiados com a linhagem de melanoma B16-F10 expressando luciferase. O crescimento tumoral foi avaliado pela captação da bioluminescência, com auxílio do sistema IVIS Spectrum. O crescimento tumoral também foi avaliado por meio de medida direta do volume com auxílio de um paquímetro. (A) Porcentagem de sobrevida após indução de sepse letal em camundongos tratados com salina ou antibiótico Ertapenen Sódico (30 mg/Kg); n=22. (B) Bioluminescência emitida pelas células tumorais no $11^{\circ}$ dia após o desafio com as células tumorais (dpd). (C) Avaliação do crescimento tumoral, com auxílio de um paquímetro. A primeira medida foi realizada no $9^{\circ} \mathrm{dpd}$ e a última no $11^{\circ} \mathrm{dpd}$. Os resultados estão expressos como média \pm EPM do volume tumoral em $\mathrm{mm}^{3}$. ${ }^{*} p<0,05$ (ANOVA seguido de Bonferroni). $n=4-8$ por grupo.

Resultados já publicados demonstram que a quadro de imunossupressão induzida pela sepse está associado a expansão das Tregs (Cavassani et al., 2010; Nascimento et al., 2010). Ainda, sabe-se que, um dos mecanismos imunossupressores utilizado pelas Tregs é a produção da citocina antiinflamatória IL-10. Assim, foram realizados experimentos para avaliar a frequência das Tregs no baço 15 dias após a indução da sepse. Além disso, pulmão dos camundongos foi coleta em diferentes dias após a CLP e utilizado para quantificar a concentração de IL-10. Os resultados demonstraram que existe um aumento na frequência das Tregs no baço dos camundongos que sobreviveram á sepse em relação aos camundongos naive (Figura 2 A e B). 
Ainda, também foi encontrado um aumento progressivo na concentração da IL-

10 no pulmão dos camundongos que sobreviveram a sepse, o qual atingiu um pico no $15^{\circ}$ dia (Figura 2 C).

A

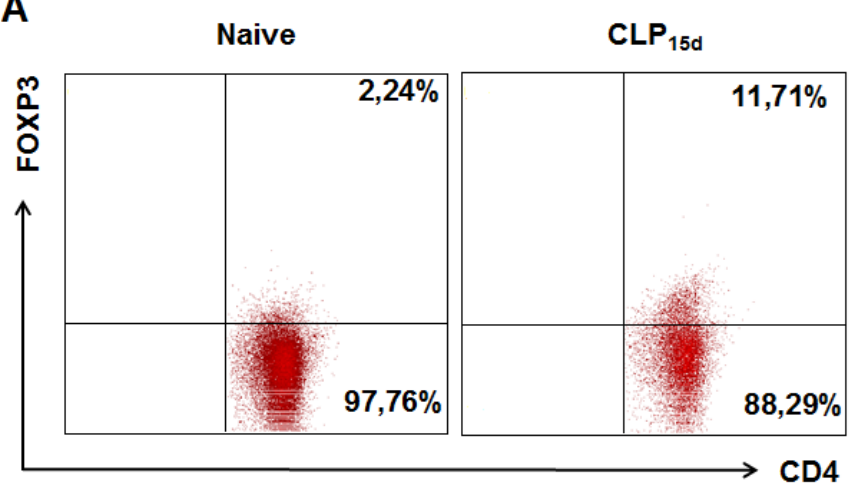

B

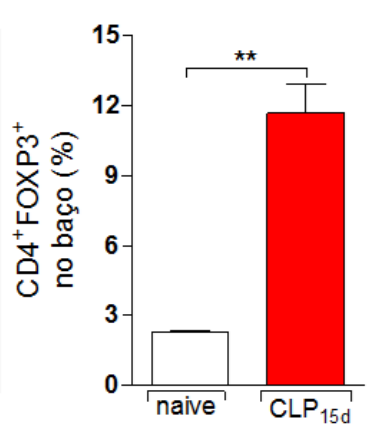

C

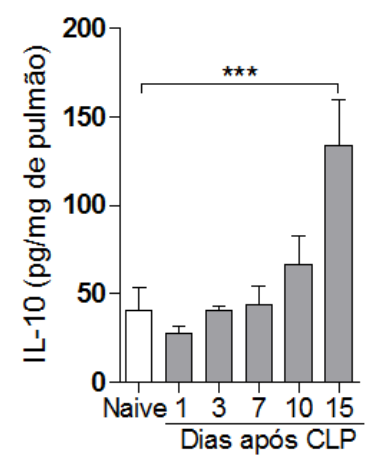

Figura 2: Avaliação da expansão das Tregs no baço de camundongos sobreviventes à sepse. Camundongos C57BL/6 WT foram submetidos à CLP e tratados com antibiótico. No $1^{\circ}$, $3^{\circ}, 7^{\circ}, 10^{\circ}$ e $15^{\circ}$ dias após a CLP o pulmão foi coletado para avaliar a concentração de IL-10 por ELISA. No $15^{\circ}$ dia após CLP, o baço foi coletado para avaliação da frequência das Tregs (células $\mathrm{CD}^{+}{ }^{+}$Foxp $^{+}$), pela técnica de citometria de fluxo. (A) Dot plot representativo da porcentagem das Tregs no baço. (B) gráfico de barras representativo do dot plot. Os resultados estão expressos como média \pm EPM em relação à mediana da intensidade de fluorescência; $n$ 4-6 por grupo. (C) Os resultados são expressos como média \pm EPM em pg/mg tecido; $n=4-5$ por grupo. ${ }^{*} p<0,05 ;{ }^{* * *} p<0,001$ (ANOVA seguido de Bonferroni). 


\subsection{Avaliação da expressão da IDO e da KMO em camundongos sobreviventes à sepse}

Sabe-se que existe um aumento na frequência das Tregs no baço de camundongos que sobrevivem à sepse. Também foi demonstrado que a IDO está associada a diferenciação das Tregs. Porém, não foi investigado se 0 aumento na frequência das Tregs observada em camundongos que sobreviveram à sepse está associado com a atividade enzimática da IDO. Assim, foram realizados experimentos para avaliar a expressão da IDO e da KMO, uma enzima associada a degradação da quinurenina, durante o desenvolvimento da imunossupressão induzida pela sepse (Diagrama 1). Para isso, o baço e pulmão de camundongos que sobreviveram à sepse foram utilizados para avaliar a expressão proteica da IDO nos dias 1, 3, 7, 10 e 15 após indução da sepse, por meio da técnica de WB. Os resultados demonstraram um aumento na expressão proteica da IDO no baço a partir do $7^{\circ}$ dia após a CLP, o qual se manteve até o 15 dia (Figura 3 A). Também foi observado um aumento da expressão proteica da enzima no pulmão a partir do $3^{\circ}$ dia após a CLP, o que se manteve até o $15^{\circ}$ dia (Figura 3 B).

Com o objetivo de confirmar os resultados apresentados anteriormente, o baço de camundongos submetidos à CLP foi coletado no $15^{\circ}$ após indução da sepse e utilizado para avaliar a expressão proteica da IDO por meio da técnica de imunofluorescência. Resumidamente, após a coleta, lâminas contendo cortes do tecido foram preparadas e coradas utilizando anticorpo específicos para IDO. Na sequência, as lâminas foram analisadas e imagens produzidas com auxílio de um microscópio confocal Leica TCS SP5, conforme descrito no item 3.12. Em linha com os resultados obtidos por meio da técnica de WB, foi identificado um 
pequeno número de células expressando a IDO no baço de camundongos naive (Figura 4 A). Por outro lado, no baço dos camundongos que sobreviveram a sepse foi notório o aumento no número de células expressando a enzima, validando assim nossos resultados anteriores, que demonstram um aumento na expressão da IDO por WB (Figura 3 A).

Em uma segunda série de experimentos, o baço e pulmão de camundongos foram coletados nos dias 1, 3, 7, 10 e 15 após a indução da sepse, para avaliar a expressão da enzima KMO. A análise do baço demonstrou uma redução em sua expressão gênica e proteica já no primeiro dia após a CLP (Figura 5 A e B), o que se manteve até o $15^{\circ}$ dia. Também foi verificado redução na expressão proteica da $\mathrm{KMO}$ no pulmão, o que ocorreu apenas no $15^{\circ}$ após a CLP (Figura 5 C). Em conjunto, nossos resultados suportam a hipótese da participação da IDO no desenvolvimento da imunossupressão induzida pela sepse. Ainda, o aumento na expressão proteica da IDO e a redução da expressão gênica e proteica da KMO sugerem um acúmulo de quinurenina nos tecidos, o que poderia favorecer a expansão das Tregs (Fallarino et al., 2006; Mezrich et al., 2010; Nguyen et al., 2010). 

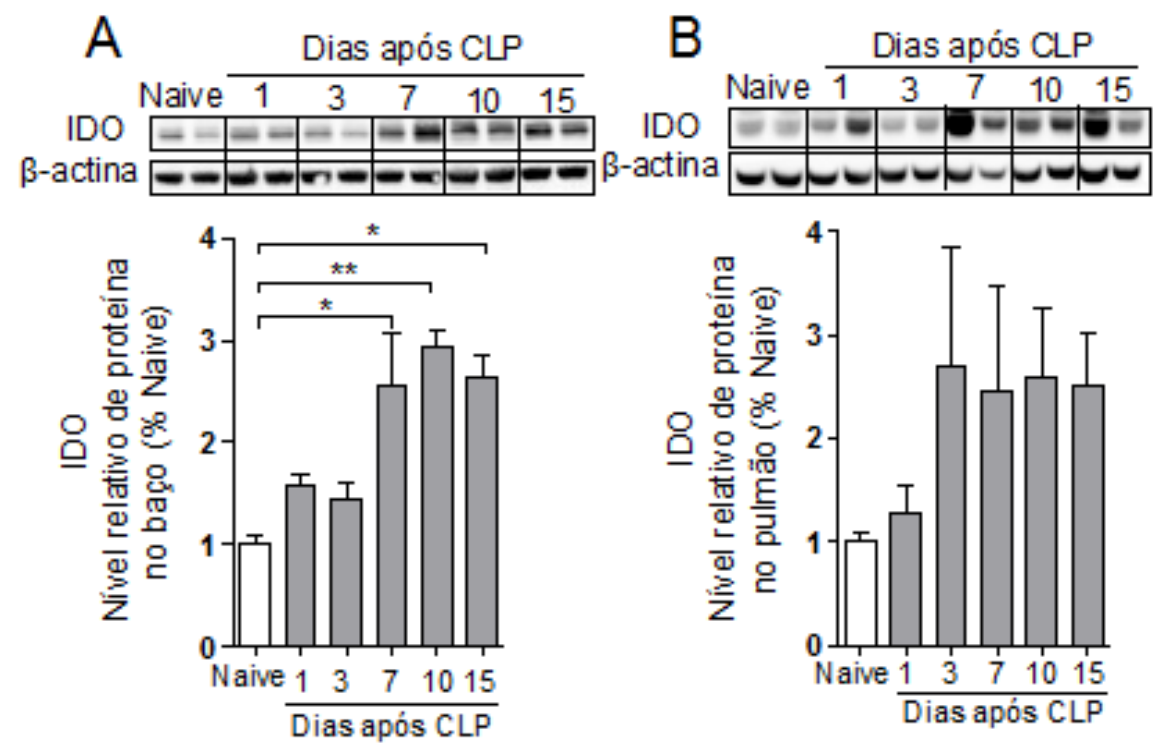

Figura 3: Avaliação da expressão proteica da IDO em camundongos sobreviventes à sepse. Camundongos C57BL/6 foram submetidos à CLP e tratados com antibiótico. No $1^{\circ}, 3^{\circ}$, $7^{\circ}, 10^{\circ}$ e $15^{\circ}$ dia após a cirurgia, (A) baço e (B) pulmão foram coletados para avaliação da expressão proteica da IDO por WB. Os resultados estão expressos como média \pm EPM em relação à expressão proteica da IDO nos camundongos naive. ${ }^{*} p<0,05 ;{ }^{* *} p<0,01$ (ANOVA seguido de Bonferroni), $n=4-5$ por grupo.

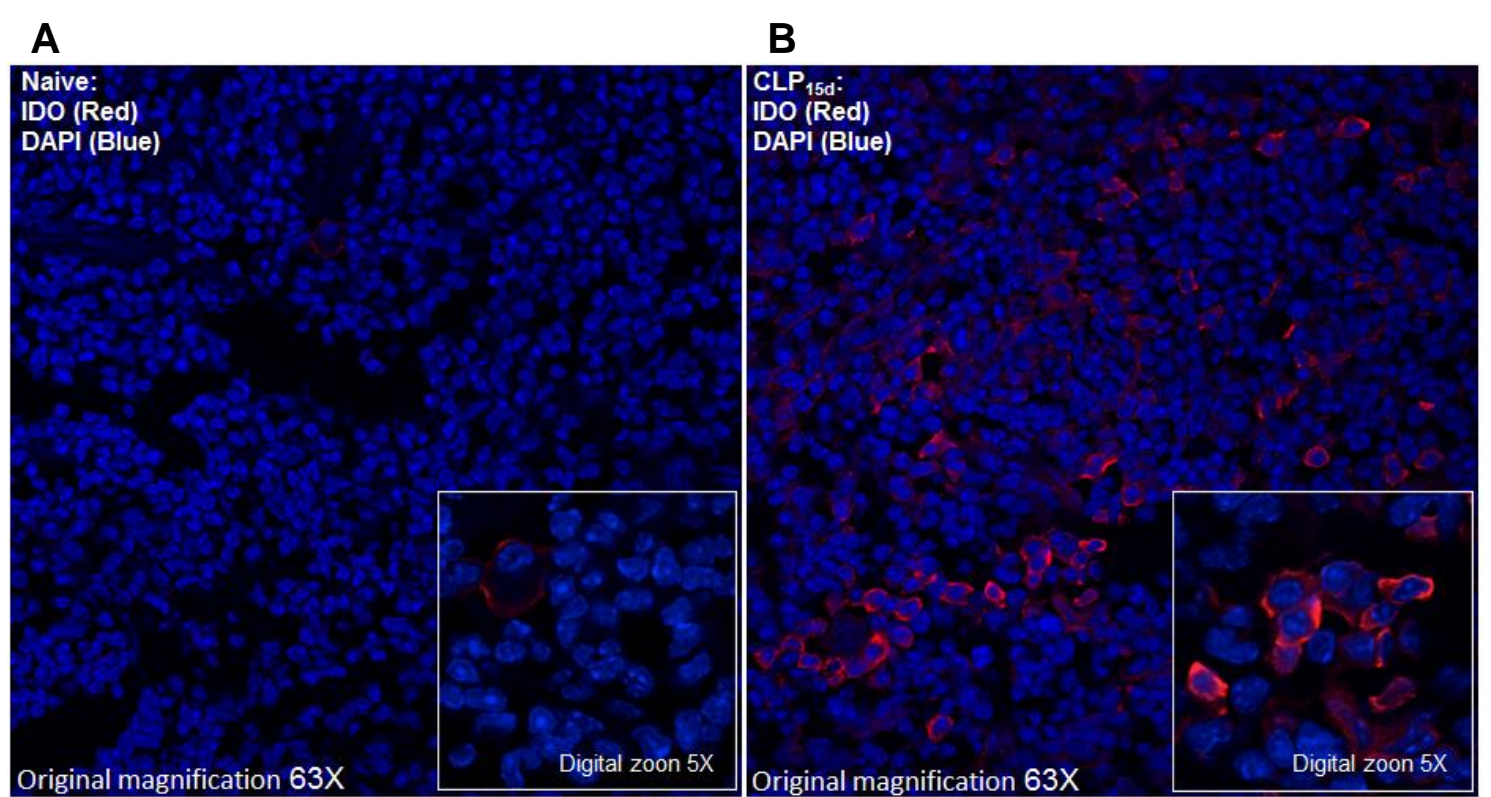

Figura 4: Avaliação da expressão da IDO em camundongos que sobreviveram à CLP. Para isso, camundongos C57BL/6 foram submetidos à CLP e tratados com antibiótico. No $15^{\circ}$ dia após a cirurgia os animais foram perfundidos, o baço coletado e fatiado em lâminas de vidro. $\mathrm{O}$ sistema foi corado seguindo protocolo previamente padronizado e as imagens produzidas com auxílio de um microscópio confocal. Foram utilizados os marcadores DAPI para núcleo (Azul) e anticorpo primário monoclonal anti-IDO 1, seguido de anticorpo secundário Alexa Flúor 594 (Vermelho). Para cada grupo, as imagens são representativas de dois animais distintos. 
A

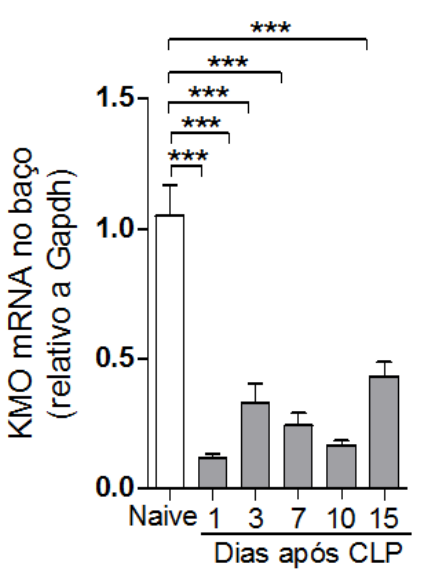

B
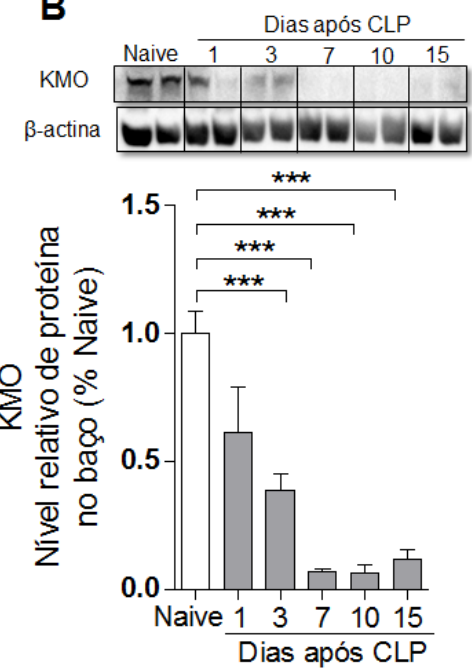

C
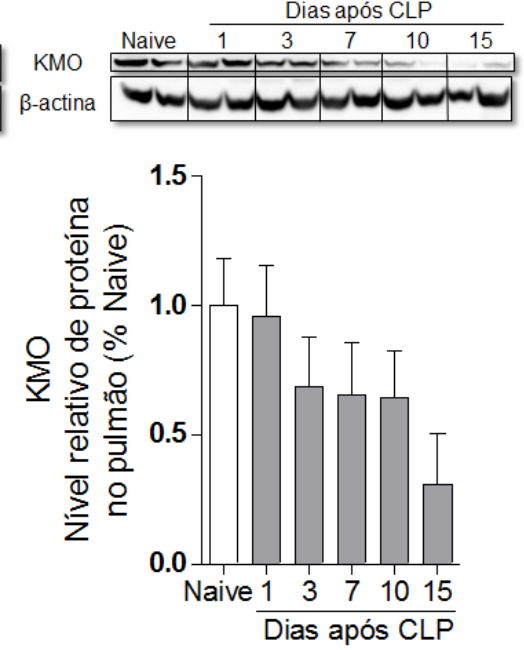

Figura 5: Avaliação da expressão gênica e proteica da KMO em camundongos sobreviventes à sepse. Camundongos C57BL/6 foram submetidos à CLP e tratados com antibiótico. No $1^{\circ}, 3^{\circ}, 7^{\circ}, 10^{\circ}$ e $15^{\circ}$ dia após a cirurgia, (A) expressão gênica no baço, (B) expressão proteica no baço e $(\mathbf{C})$ expressão proteica no pulmão. Para os experimentos de real time-RT PCR os resultados estão expressos como média \pm EPM em relação à expressão gênica do GAPDH. Para os experimentos de western blotting os resultados estão expressos como média \pm EPM em relação à expressão proteica da KMO nos camundongos naive. ${ }^{* * *} p<0,001$ (ANOVA seguido de Bonferroni), $n=3-10$ por grupo.

\subsection{Avaliação da razão quinurenina/triptofano e da atividade enzimática da IDO em camundongos sobreviventes à sepse}

Dados da literatura demonstram que ocorre um aumento da expressão proteica da enzima IDO em leucócitos circulantes e da razão quinurenina/triptofano no soro de pacientes sépticos, o que foi associado a um mau prognóstico da doença (Huttunen et al., 2010; Ploder et al., 2010; Tattevin et al., 2010; Darcy et al., 2011; Hotchkiss et al., 2013a). Assim, foram realizados experimentos para avaliar a razão quinurenina/triptofano no soro, para avaliar o papel da quinurenina no agravamento da sepse e para avaliação da atividade da IDO no pulmão e baço de camundongos, em diferentes dias após a CLP. 
Primeiramente, camundongos foram submetidos a uma sepse grave ou moderada. No $3^{\circ}$ dia após a indução da sepse o soro dos animais foi coletado e utilizado para avaliação da razão quinurenina/triptofano, por meio da técnica de HPLC, conforme descrito no item 3.10. A análise dos dados demonstrou que não existe aumento na relação quinurenina/triptofano no soro do camundongo submetido a uma sepse moderada em relação aos animais naive. Por outro lado, foi encontrado um aumento na relação quinurenina/triptofano no soro do camundongo submetido a uma sepse letal, quando comparado aos camundongos naive (Figura 6 A).

Para confirmar o papel prejudicial da quinurenina durante a fase aguda da sepse, camundongos foram submetidos a uma sepse moderada e tratados com salina ou quinurenina pela via oral. Um terceiro grupo de animais foi submetido a uma sepse grave e utilizado como controle. É importante ressaltar que, os três grupos foram tratados com antibiótico $6 \mathrm{~h}$ após indução da sepse e de 12 em 12 h até o terceiro dia, conforme descrito no item 3.3.2. A análise dos resultados demonstrou uma alta taxa de mortalidade no grupo de camundongos submetidos a uma sepse letal. Enquanto que, camundongos submetidos a uma sepse moderada, apresentaram uma baixa taxa de mortalidade, demonstrando que é possível modular a gravidade da sepse induzida pelo modelo de CLP. Por fim, em concordância com os resultados apresentados neste tópico, foi encontrado um aumento na mortalidade dos animais submetidos a uma sepse moderada tratados com quinurenina em ralação ao grupo submetido a uma sepse moderada e tratados com salina (Figura 6 B). Dessa forma, assim como em pacientes, os resultados demonstram que um aumento da relação 
quinurenina/triptofano é um mau prognóstico e um indicativo da gravidade da sepse.

Em outra bateria de experimentos, o pulmão e o baço de camundongos foi coletado nos dias 1,7 e 15 após a indução de uma sepse grave e utilizados para avalição da atividade enzimática da IDO, conforme descrito no item 3.11. A análise dos resultados demonstrou que existe um aumento da atividade da enzima no baço dos camundongos no $15^{\circ}$ após a indução da sepse (Figura 7 A), sendo que, não foi observado alteração na atividade da enzima no pulmão (Figura 7 B).
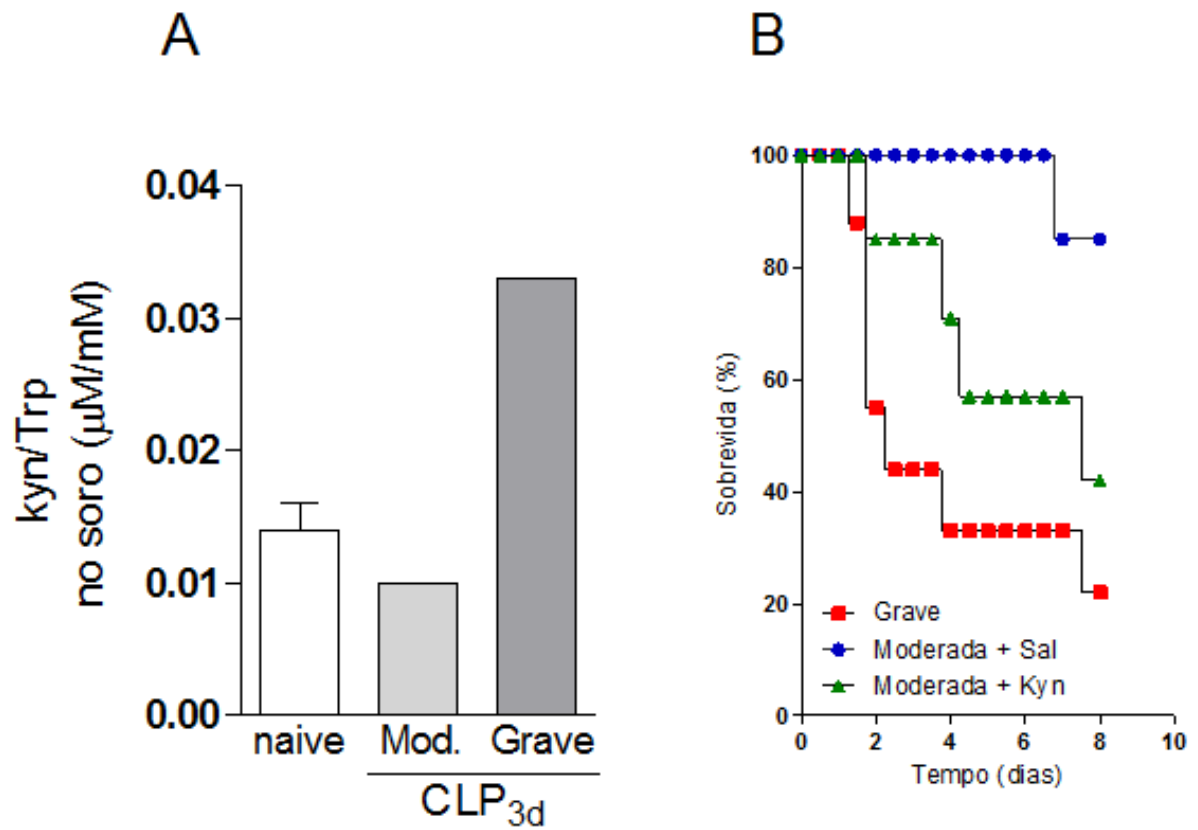

Figura 6: Avaliação da razão Kyn/Trp em camundongos sobreviventes à sepse. Camundongos C57BL/6 foram submetidos a uma CLP moderada ou grave e tratados com antibiótico. (A) No $3^{\circ}$ dia após a cirurgia o soro foi coletado para quantificação dos níveis de quinurenina e triptofano circulantes pela técnica de HPLC. Os resultados estão expressos como média $\pm \mathrm{EPM} \mathrm{em} \mu \mathrm{mol} / \mathrm{mM}$. (B) Camundongos foram submetidos a um sepse moderada $\mathrm{e}$ tratados pela via oral com salina ou quinurenina. Camundongos submetidos a uma sepse grave foram utilizados como controles. Todos os grupos receberam tratamento com Ertapenen Sódico $(30 \mathrm{mg} / \mathrm{Kg})(\mathrm{A}) \mathrm{n}=1-2$ e (B) $n=7-9$ por grupo. ${ }^{* * *} p<0,001$ (ANOVA seguido de Bonferroni). 
A

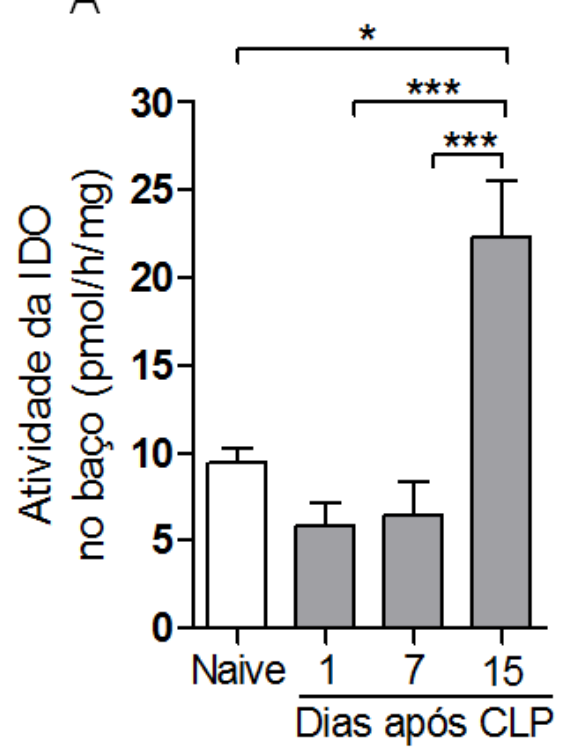

B

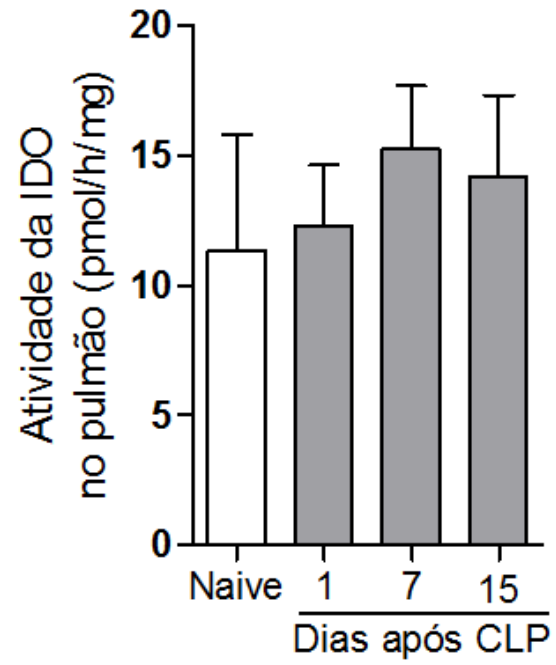

Figura 7: Avaliação da atividade enzimática da IDO em camundongos sobreviventes à sepse. Camundongos C57BL/6 foram submetidos à CLP e tratados com antibiótico. No $1^{\circ}, 3^{\circ}$, $7^{\circ}, 10^{\circ}$ e $15^{\circ}$ dia após a cirurgia, (A) Baço e (B) pulmão foram coletados. Os tecidos foram utilizados para avaliação da atividade enzimática da IDO pela técnica de HPLC. Os resultados estão expressos como média \pm EPM em pmol/h/mg de tecido. * $p<0,05 ;{ }^{* * *} p<0,001$ (ANOVA seguido de Bonferroni), $n=6-7$ por grupo.

\subsection{Avaliação do papel da IDO no desenvolvimento da imunossupressão induzida pela sepse}

Resultados apresentados neste trabalho sugerem a participação da IDO no desenvolvimento da imunossupressão induzida após a sepse. Assim, para avaliar a relação da IDO com o desenvolvimento da imunossupressão, camundongos que sobreviveram a sepse foram tratados com um inibidor da atividade enzimática da IDO durante 10 dias (Figura 8). Ainda, para avaliar o grau de imunossupressão, 15 dias após indução da sepse, os camundongos foram desafiados com células do melanoma B16-F10 expressando luciferase. $\mathrm{O}$ crescimento tumoral foi avaliado no $6^{\circ}$ dia após o desafio, pela captação de 
bioluminescência, ou por meio de medidas diárias do volume, com auxílio de um paquímetro (Figura 8).

A avaliação do volume tumoral pela captação da bioluminescência (Figura 8 B e C) ou pela medida direta com paquímetro (Figura 8 D), demonstrou um maior crescimento do melanoma nos camundongos submetidos à CLP e tratados com salina, quando comparados aos camundongos naive. Esse resultado, confirma que camundongos que sobrevivem à sepse desenvolvem um quadro de imunossupressão (Cavassani et al., 2010; Nascimento et al., 2010). Ainda, a análise dos dados demonstrou que o tratamento dos camundongos submetidos à CLP com inibidor da IDO foi efetivo em reduzir o crescimento tumoral apresentado pelos camundongos submetidos à CLP e tratados com salina (Figura 8). 
A
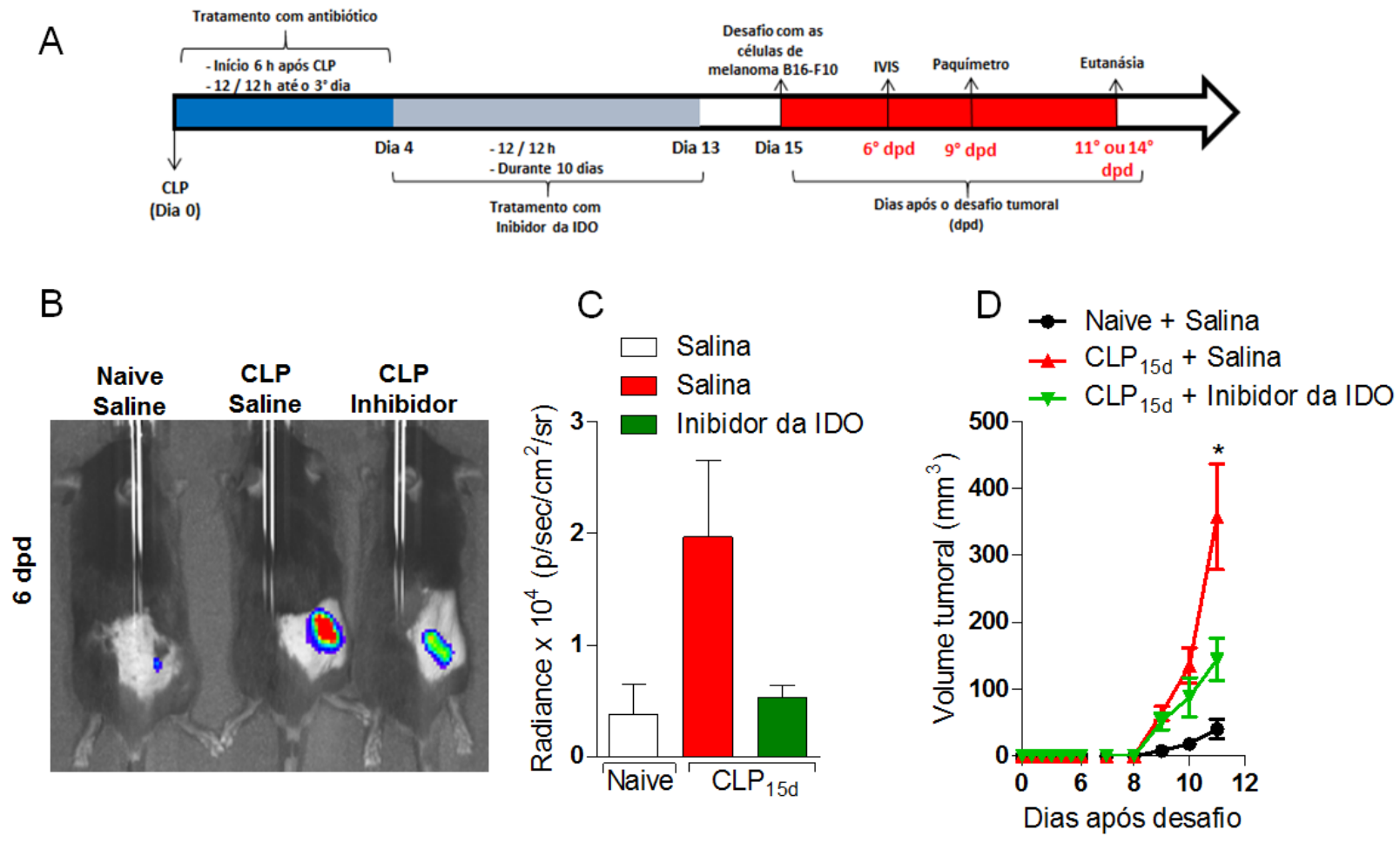

Figura 8: Quantificação do crescimento tumoral em camundongos sobreviventes à sepse. Camundongos C57BL/6 WT foram submetidos à CLP e tratados com antibiótico. No $4^{\circ}$ dia após a CLP foi iniciado o tratamento com um inibidor da IDO, denominado 1-metil-DL-triptofano (DL$1 \mathrm{MT}$ ), com duração de 10 dias. No $15^{\circ}$ dia após CLP, os camundongos foram desafiados com a linhagem de melanoma B16-F10 expressando luciferase. O crescimento tumoral foi avaliado pela captação da bioluminescência, com auxílio do sistema IVIS Spectrum. O crescimento tumoral também foi avaliado por meio de medida direta do volume com auxílio de um paquímetro. (A) Diagrama representativo dos procedimentos utilizados para realização do experimento. (B) Bioluminescência emitida pelas células tumorais no $6^{\circ}$ dia após o desafio com as células tumorais (dpd). (C) Quantificação da intensidade de bioluminescência emitida pelas células tumorais no $6^{\circ} \mathrm{dpd}$. Os resultados estão expressos como média \pm EPM em intensidade de radiância ( $\mathrm{p} / \mathrm{sec} / \mathrm{cm}^{2} / \mathrm{sr}$ ). (D) Avaliação do crescimento tumoral, com auxílio de um paquímetro. A primeira medida foi realizada no $9^{\circ} \mathrm{dpd}$ e a última no $11^{\circ} \mathrm{dpd}$. Os resultados estão expressos como média \pm EPM do volume tumoral em $\mathrm{mm}^{3}$. ${ }^{*} p<0,05$ (ANOVA seguido de Bonferroni). $n=5$ por grupo.

\subsection{Avaliação do papel da IDO na expansão de Tregs observada em}

\section{camundongos sobreviventes à sepse}

Os resultados apresentados anteriormente sugerem que o aumento na expressão proteica da IDO, observado no baço de camundongos que sobreviveram à sepse, está relacionado ao desenvolvimento do quadro de 
imunossupressão. Ainda, dados já publicados, demonstram que a quinurenina produzida pela IDO está associada com a diferenciação das Tregs. Assim, foram realizados experimentos para determinar se a atividade enzimática da IDO estaria relacionada com a expansão das Tregs, que ocorre durante 0 desenvolvimento da imunossupressão induzida pela sepse. Para isso, camundongos foram submetidos à CLP e tratados com o inibidor da IDO, DL1MT, conforme descrito no item 3.3.4 (Figura 9 A).

Em concordância com resultados apresentados neste trabalho, foi encontrado um aumento na frequência das Tregs no baço dos camundongos submetidos à sepse e tratado com salina. Por outro lado, foi observado uma redução na frequência das Tregs no baço dos animais submetidos à sepse e tratados com o inibidor da IDO (Figura 9 B e C). Assim, este resultado demonstra que a atividade enzimática da IDO está envolvida com o aumento na frequência das Tregs no baço de camundongos que sobrevivem à sepse. 
A

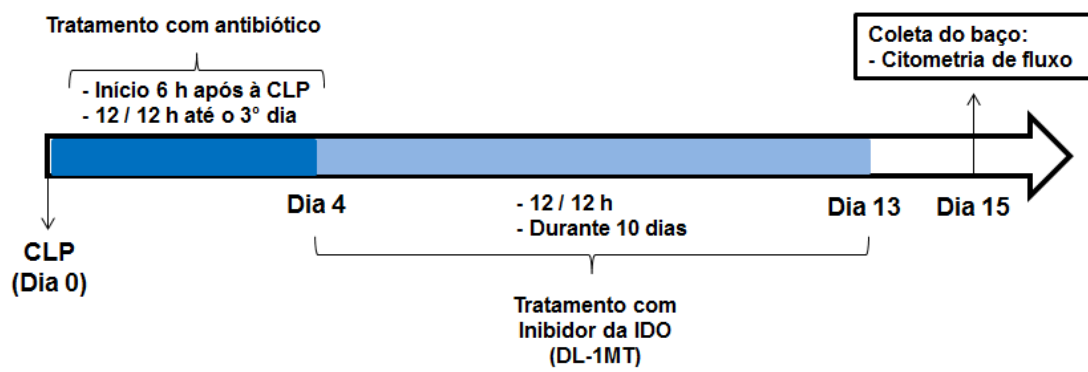

B

(DL-1MT)

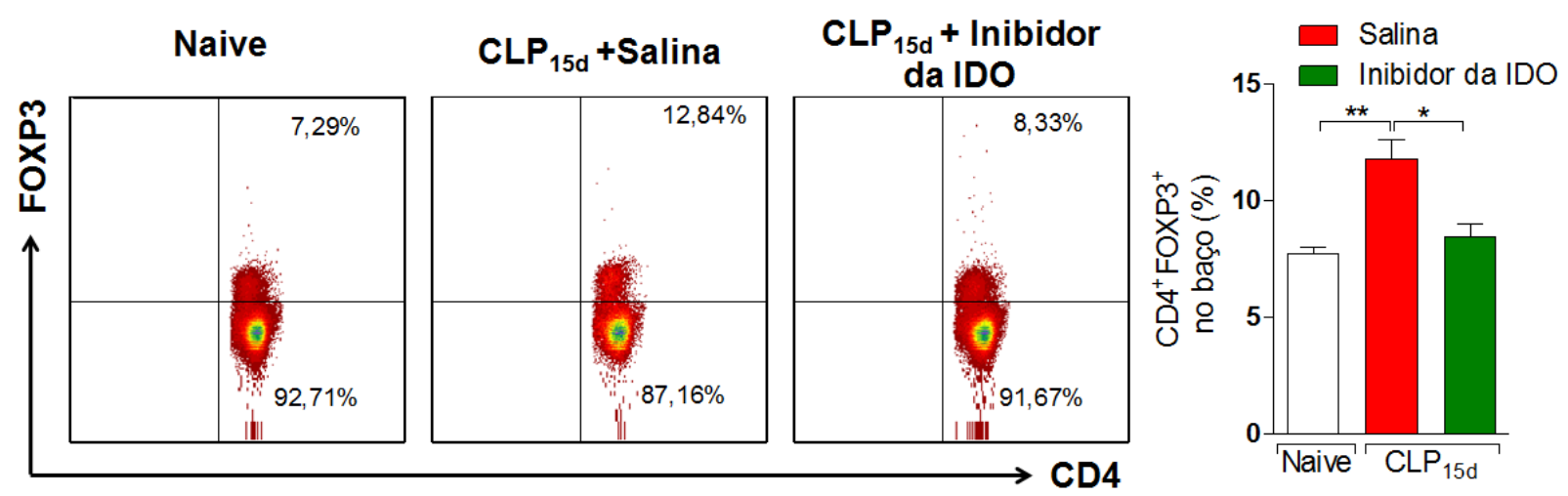

Figura 9: Avaliação do papel da IDO na expansão das Tregs observada em camundongos sobreviventes à sepse. (A) Camundongos $\mathrm{C} 57 \mathrm{BL} / 6$ foram submetidos à CLP e tratados com antibiótico. No $4^{\circ}$ dia após CLP, foi iniciado o tratamento com um inibidor da IDO, denominado 1-metil-DL-triptofano (DL-1MT), com duração de 10 dias. No $15^{\circ}$ dia após CLP, o baço foi coletado para avaliação da frequência das Tregs (células $\mathrm{CD} 4^{+} \mathrm{Foxp} 3^{+}$) pela técnica de citometria de fluxo. (B) Dot plot representativo da porcentagem das Tregs no baço. (C) gráfico de barras representativo do dot plot. Os resultados estão expressos como média \pm EPM em relação à mediana da intensidade de fluorescência. * $p<0,05 ;{ }^{* *} p<0,01$ (ANOVA seguido de Bonferroni), $n$ $=4-6$ por grupo .

\subsection{Avaliação dos mecanismos associados ao controle do crescimento tumoral após o tratamento com inibidor da IDO}

Os dados apresentados até aqui demonstram que a atividade enzimática da IDO está associada ao desenvolvimento da imunossupressão induzida pela sepse por promover a expansão das Tregs. Assim, o próximo objetivo deste trabalho foi avaliar quais mecanismos estariam relacionados à resposta antitumoral mais eficiente observada nos camundongos tratados com o inibidor da IDO. Para isso, o baço de camundongos foi coletado no $11^{\circ} \mathrm{dpd}$ para avalição 
da frequência das myeloid-derived suppressor cells (MDSC), uma população celular cuja diferenciação é induzida pelas células tumorais e que possuem propriedades supressoras sobre outras células do sistema imune. Além disso, no $14^{\circ} \mathrm{dpd}$ o linfonodo drenante da região tumoral foi coletado para avaliação da frequência de células $\mathrm{CD}^{+}$produtoras de IFN-Y, conforme descrito no item 3.5 (Figura 8 A).

A análise dos resultados demonstrou um aumento seletivo na população de células $\mathrm{CD} 11 \mathrm{~b}^{+} \mathrm{Ly}_{6 \mathrm{G}}{ }^{+}$nos camundongos submetidos à CLP e tratados com salina, quando comparados aos camundongos naive. Por outro lado, ocorreu redução na frequência das células $C D 11 b^{+} L y 6 G+$ em camundongos submetidos à CLP e tratados com inibidor da IDO, quando comparados a animais submetidos à CLP e tratados com salina (Figura $10 \mathrm{~A}$ ). Não foi observado aumento da frequência das células $C D 11 b^{+} L_{6} 6 C^{+}$nos camundongos submetidos à CLP em relação aos animais naive (Figura $10 \mathrm{~B}$ ). Por fim, os dados demonstraram um aumento na frequência de células $\mathrm{CD} 8^{+} \mathrm{IFN}-Y^{+}$no linfonodo dos camundongos tratados com DL-1MT (Figura 11). 


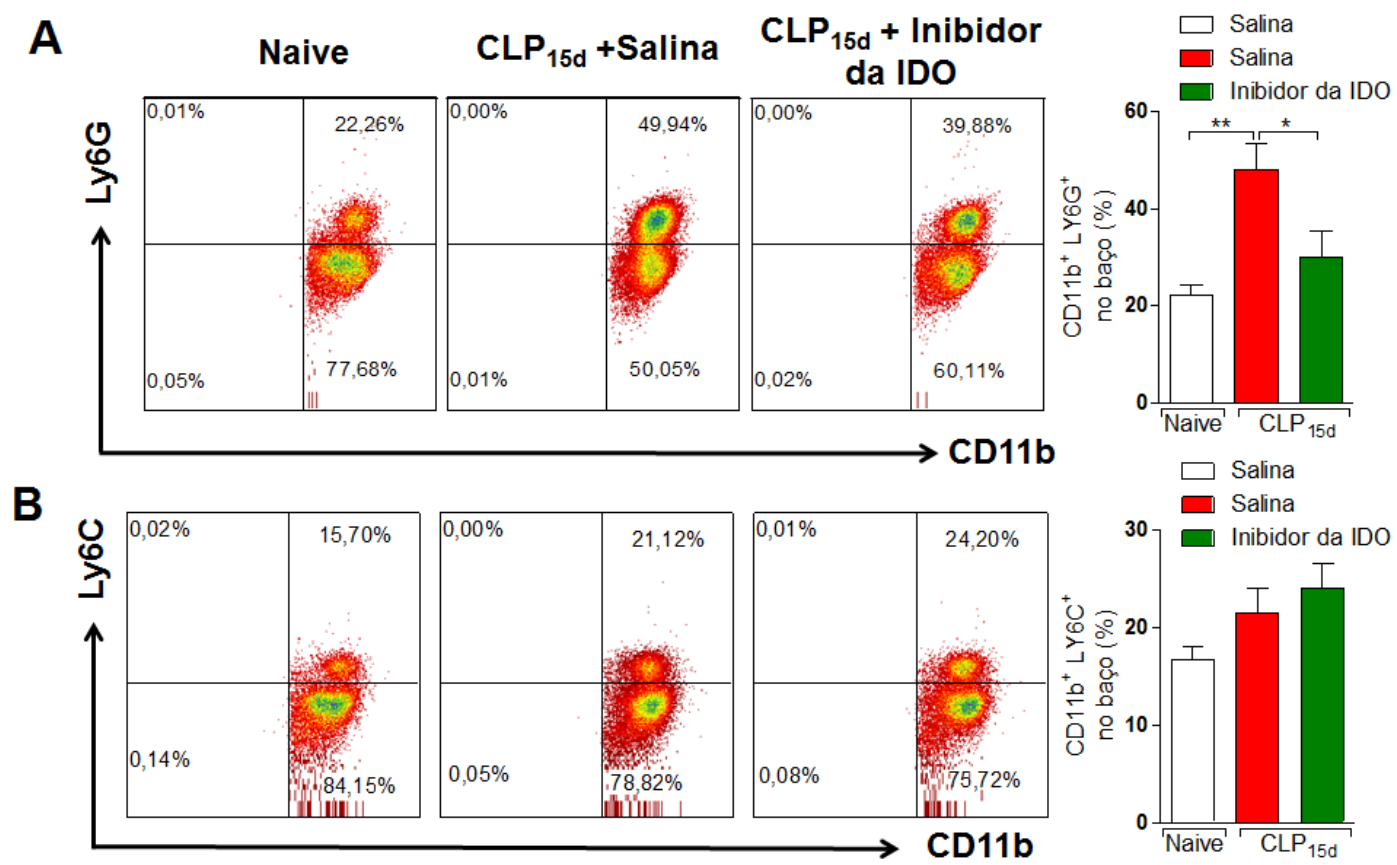

Figura 10: Avaliação da frequência das MDSCs no baço de camundongos sobreviventes à sepse 11 dias após o desafio tumoral. Camundongos C57BL/6 foram submetidos à CLP e tratados com antibiótico. No $4^{\circ}$ dia após a CLP foi iniciado o tratamento com um inibidor da IDO, denominado 1-metil-DL-triptofano (DL-1MT), durante 10 dias. No $15^{\circ}$ dia após a CLP, os camundongos foram desafiados com a linhagem de melanoma B16-F10 expressando luciferase. No $11^{\circ}$ dia após o desafio com as células tumorais ( $\mathrm{dpd}$ ) foi realizada a coleta do baço para avaliação da frequência de células MDSC. (A) Dot plot e gráfico de barras representativo da porcentagem de células CD11b+ Ly6G+. (B) Dot plot e gráfico de barras representativo da porcentagem de células $C D 11 b^{+} L_{6} 6 C^{+}$. Os resultados estão apresentados como mediana da intensidade de fluorescência. * $p<0,05$; ${ }^{* *} p<0,01$ (ANOVA seguido de Bonferroni). $n=5$ por grupo. 
A

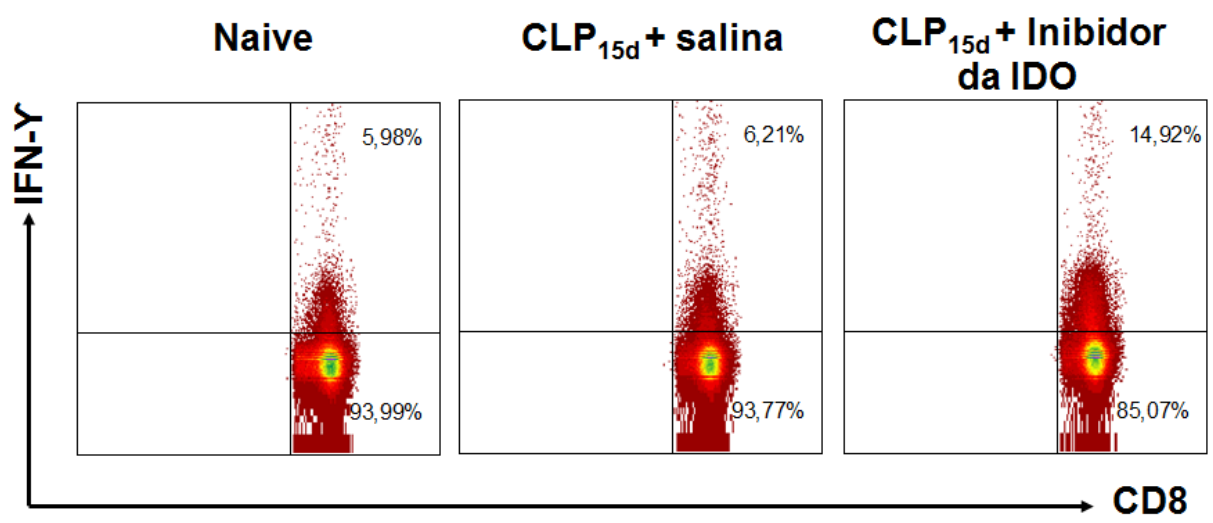

B

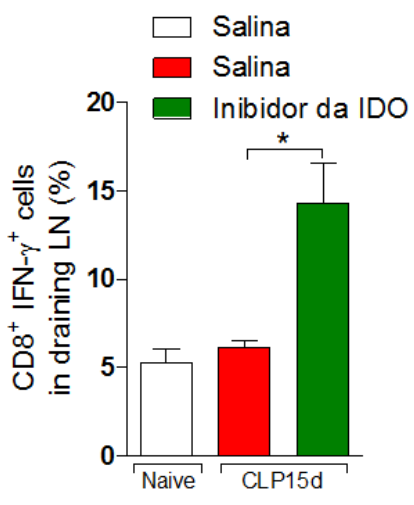

Figura 11: Avaliação da frequência de células $\mathrm{CD8}^{+}$IFN $-Y^{+}$no baço de camundongos sobreviventes à sepse 14 dias após o desafio tumoral. Camundongos C57BL/6 foram submetidos à CLP e tratados com antibiótico. No $4^{\circ}$ dia após a CLP, foi iniciado o tratamento com um inibidor da IDO, denominado 1-metil-DL-triptofano (DL-1MT), o que teve duração de 10 dias. No $15^{\circ}$ dia após a CLP, os camundongos foram desafiados com a linhagem de melanoma B16-F10 expressando luciferase. No $14^{\circ}$ após o desafio com as células tumorais (dpd) foi realizada a coleta do linfonodo drenate da região tumoral para avaliação da frequência de células CD8 ${ }^{+}$produtoras de INF-Y. (A) Dot plot representativo da porcentagem de $\mathrm{CD} 8^{+} \mathrm{INF}-\mathrm{Y}^{+}$. (B) Gráfico de barras representativo da porcentagem de células $\mathrm{CD} 8^{+} \mathrm{INF}-\mathrm{Y}^{+}$. Os resultados estão apresentados como mediana da intensidade de fluorescência. * $p<0,05$; (ANOVA seguido de Bonferroni). $n=3-4$ por grupo.

\subsection{Avaliação das vias associadas ao aumento da expressão proteica da IDO em camundongos sobreviventes à sepse}

Nossos dados demonstraram que a atividade enzimática da IDO está associada à expansão das Tregs e com o desenvolvimento da imunossupressão em camundongos que sobreviveram à sepse grave. Resultados encontrados em nosso laboratório demonstram que existe um aumento na diferenciação de macrófagos M2 em camundongos que sobrevivem à sepse, o que foi importante para a expansão das Tregs e para o desenvolvimento do quadro de imunossupressão que ocorrem após a sepse. Nesse sentido, foram realizados experimentos para determinar se a atividade enzimática da IDO estava associada com a diferenciação de macrófagos M2 observado após a sepse. 
Primeiramente, o pulmão de camundongos submetidos a uma sepse grave foi coletado para avaliação da produção das citocinas IL-4, IL-13 e IL-33, sabidamente importantes para a diferenciação dos macrófagos para um perfil M2. Em um segundo experimento, camundongos foram submetidos a sepse grave, e tratados com o inibidor da IDO durante 10 dias (Figura 12 D). No $15^{\circ}$ dia após a CLP, o lavado peritoneal foi coletado para avaliação da frequência de macrófagos $\mathrm{M} 2\left(\mathrm{~F} 4 / \mathrm{F} 80^{+} \mathrm{MR}^{+}\right)$.

A análise dos resultados demonstrou que existe um aumento progressivo na concentração das citocinas IL-4, IL-13 e IL-33, com pico no $15^{\circ}$ dia após a sepse (Figura 12 A, B e C). Também foi demonstrado que o tratamento com DL1MT não alterou a frequência de macrófagos M2 no lavado peritoneal dos camundongos submetidos à CLP (Figura 12 E e F). Dessa forma, nossos resultados indicam que a atividade enzimática da IDO não está envolvida com a diferenciação de macrófagos para um perfil M2 em animais que sobrevivem à sepse, sugerindo que, a expansão das Tregs induzida pela atividade enzimática da IDO não depende da diferenciação de macrófagos M2. 


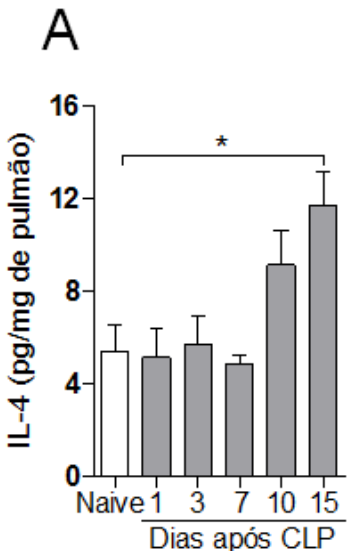

B

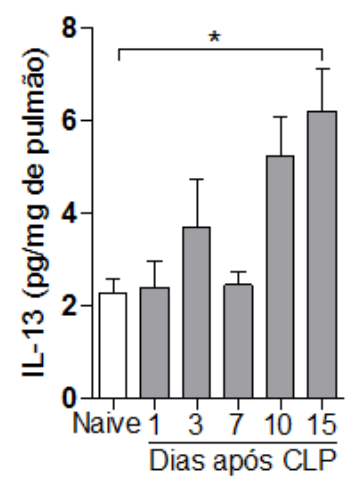

C

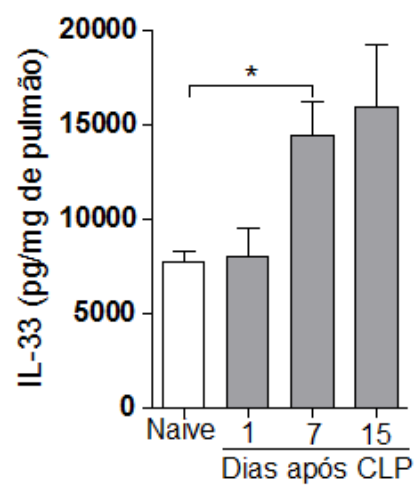

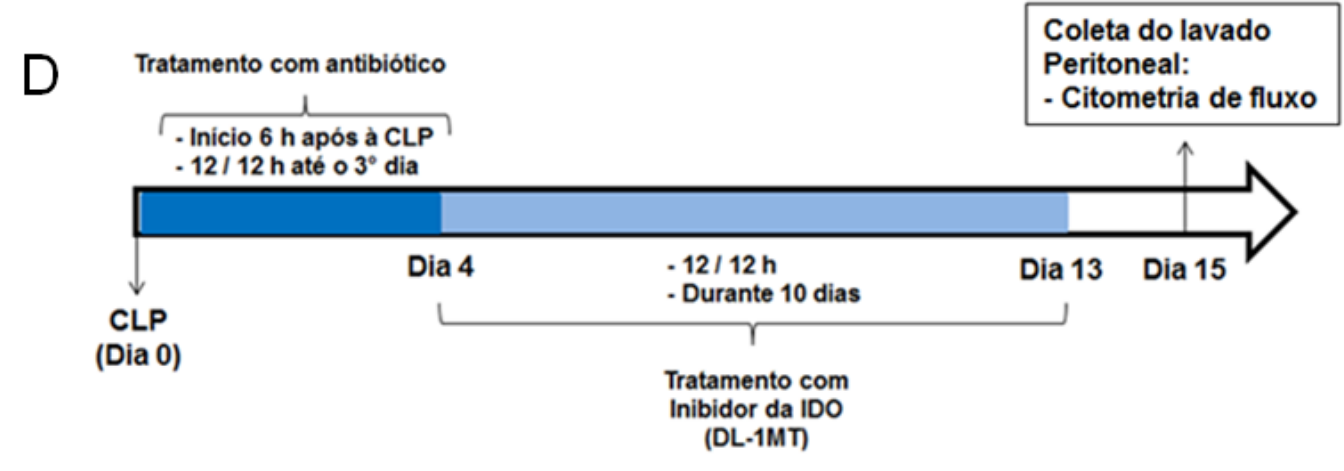

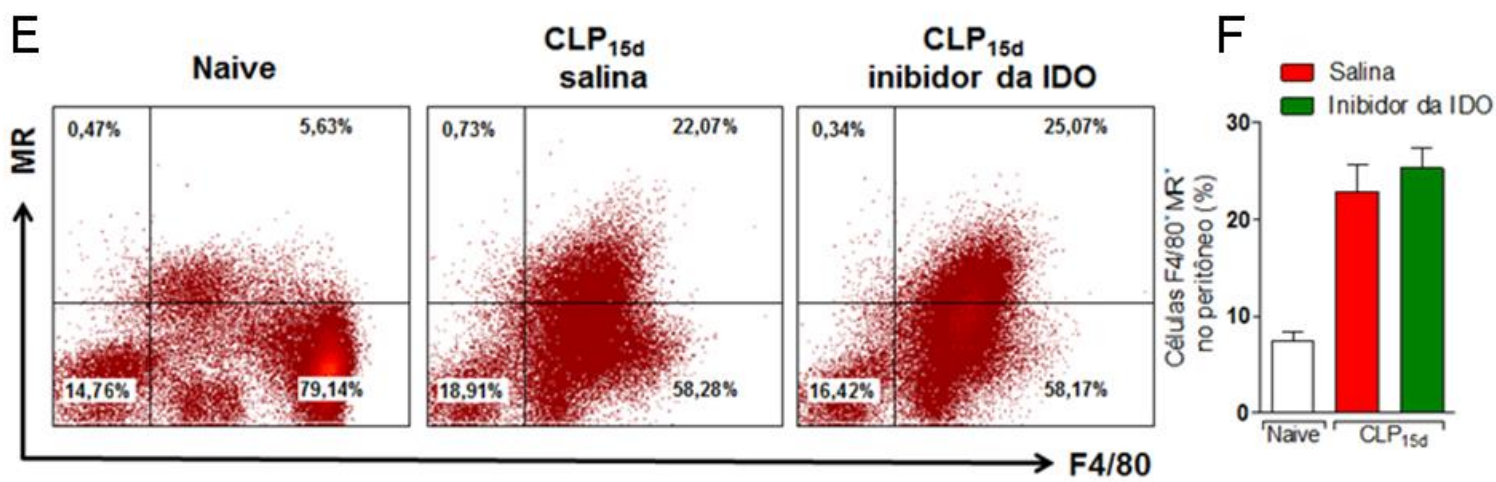

Figura 12: Avaliação do papel da IDO na diferenciação de macrófagos M2 observada em camundongos sobreviventes à sepse. (A-C) Camundongos C57BL/6 WT foram submetidos à CLP e tratados com antibiótico. No $1^{\circ}, 3^{\circ}, 7^{\circ}, 10^{\circ}$ e $15^{\circ}$ dia após a CLP o pulmão foi coletado para avaliar a concentração das citocinas IL-4, IL-13 e IL-33 por ELISA. Os resultados são expressos como média \pm EPM em pg/mg tecido; $n=4-6$ por grupo. (D) No $4^{\circ}$ dia após a CLP foi iniciado o tratamento com um inibidor da IDO denominado 1-metil-DL-triptofano (DL-1MT), durante 10 dias. No $15^{\circ}$ dia após a cirurgia, foi realizada a coleta do lavado. (E) Dot plot representativo da porcentagem de macrófagos $M 2$ (células $F 4 / 80^{+} M R^{+}$) no lavado peritoneal. (F) gráfico de barras representativo do dot plot. Os resultados estão expressos como média \pm EPM em relação à mediana da intensidade de fluorescência; $n=3-5$ por grupo. * $p<0,05$; (ANOVA seguido de Bonferroni. 
Dados encontrados na literatura demonstram que citocinas produzidas durante a inflamação como interferons (IFN)- $\alpha, \beta$ e $y$ além de componentes bacterianos como o LPS e CpG, são grandes indutores da expressão da IDO (Taylor et al., 1991; Puccetti, 2007; Pallotta et al., 2011; Fallarino et al., 2015). Assim, foram realizados experimentos com o objetivo de avaliar o papel do interferon $Y$ no desenvolvimento da imunossupressão induzida pela sepse.

Para isso, camundongos IFN- $\gamma$ foram submetidos à CLP, conforme descrito no item 3.4 . No $15^{\circ}$ dia após a cirurgia, o baço foi coletado para avaliação da frequência das Tregs. A análise dos resultados demonstrou que a falta da citocina IFN-y não reduziu a frequência das Tregs no baço dos camundongos no $15^{\circ}$ dias após a sepse (Figura 13). De fato, os camundongos IFN-ץ KO submetidos à CLP apresentaram maior frequência das Treg quando comparados aos camundongos WT submetidos à CLP. 
A

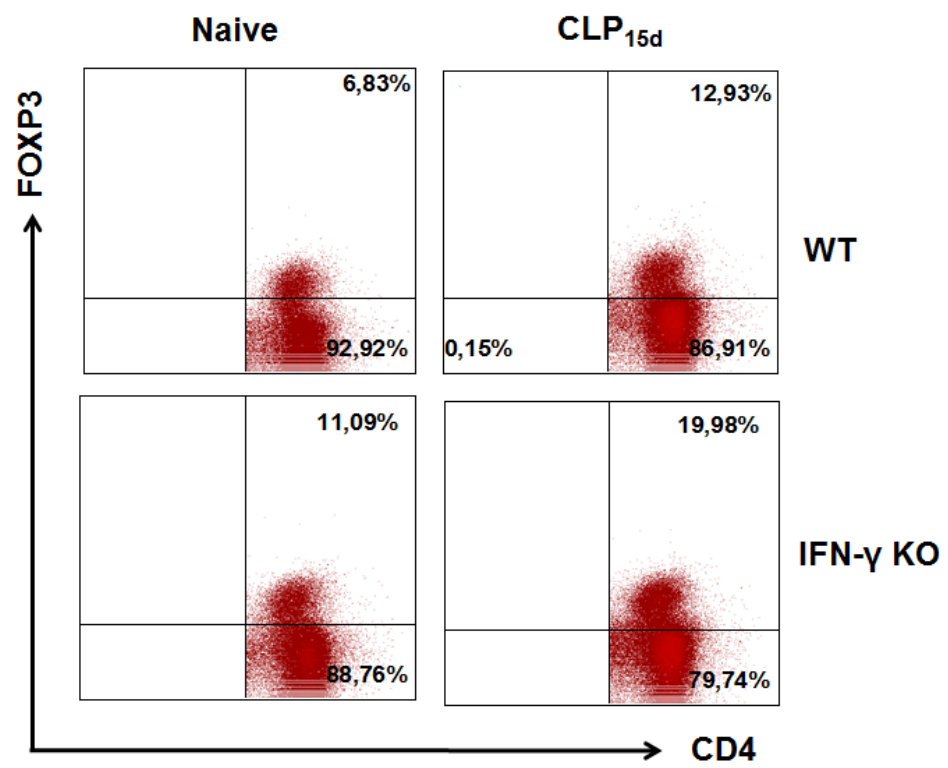

B

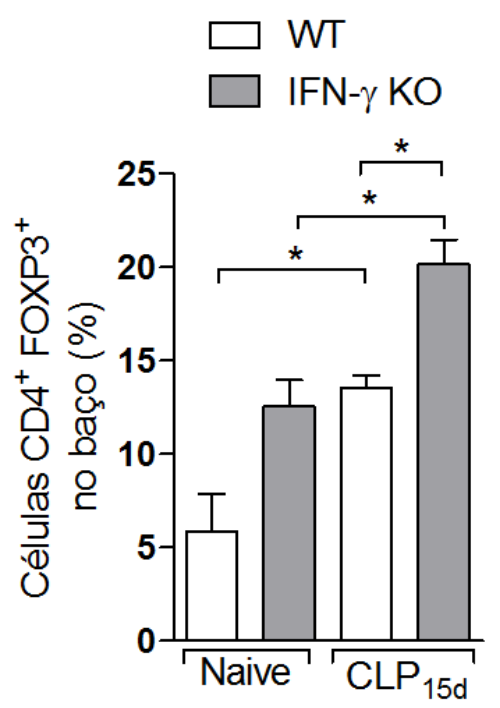

Figura 13: Avaliação do papel do IFN- $y$ na diferenciação das Tregs em camundongos sobreviventes à sepse. Camundongos C57BL6/ WT ou deficientes para a produção da citocina IFN-y foram submetidos à CLP e tratados com antibiótico. No $15^{\circ}$ dia após CLP, o baço foi coletado para avaliação da frequência das Tregs (células $\mathrm{CD}^{+}{ }^{+} \mathrm{Foxp} 3^{+}$) pela técnica de citometria de fluxo. (A) Dot plot representativo da porcentagem das Tregs no baço. (B) gráfico de barras representativo do dot plot. Os resultados estão expressos como média \pm EPM em relação à mediana da intensidade de fluorescência. ${ }^{* *} p<0,01 ;{ }^{* * *} p<0,001$ (ANOVA seguido de Bonferroni), $n=2-6$ por grupo.

Resultados ainda não publicados por nosso grupo demonstram que existe um aumento da expressão proteica do AhR durante a fase inicial da sepse grave. Também foi demonstrado que a ativação do AhR está associada ao aumento da expressão gênica da IDO (Quintana et al., 2013; Bessede et al., 2014). Outros trabalhados demonstraram que a quinurenina, o produto da ação enzimática da IDO sobre o triptofano, é capaz de ativar o AhR expresso em linfócitos, promovendo a diferenciação das Tregs (Mezrich et al., 2010; Nguyen et al., 2010; Quintana et al., 2013). Ainda, nossos resultados demonstram que no terceiro dia após a sepse existe um aumento na produção de quinurenina (Figura 5), o que promoveu o agravamento da sepse. Assim, foram realizados experimentos com 
o objetivo de avaliar se o AhR estaria envolvido com o aumento da expressão proteica da IDO observada em camundongos que sobreviveram à sepse.

Primeiramente, o baço de camundongos submetidos à CLP foi coletado nos dias 1, 3, 7, 10 e 15 após a indução da sepse e utilizado para quantificar a expressão proteica do AhR, por meio da técnica de WB. A análise dos resultados demonstrou um aumento na expressão do AhR já nos primeiros dias após à sepse. De fato, foi detectado um aumento no $1^{\circ}$ dia após a sepse com pico no $3^{\circ}$ dia (Figura 14). O aumento na expressão proteica do receptor durante a fase inicial da sepse foi seguido por uma queda no $10^{\circ}$ dia, retornando a um padrão basal de expressão no $15^{\circ}$ dia após a CLP.
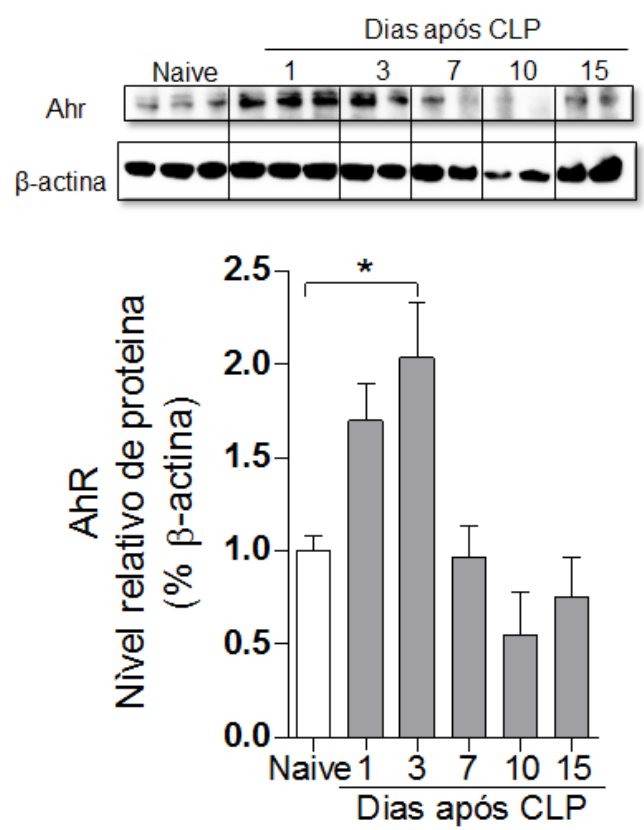

Figura 14: Avaliação da expressão proteica do AhR em camundongos sobreviventes à sepse. Camundongos C57BL/6 foram submetidos à CLP e tratados com antibiótico. No $1^{\circ}, 3^{\circ}$, $7^{\circ}, 10^{\circ}$ e $15^{\circ}$ dia após a cirurgia, o baço foi coletado para avaliação da expressão proteica do Ahr por WB. Os resultados estão expressos como média \pm EPM em relação à expressão proteica da $\beta$-actina. * $p<0,05$ (ANOVA seguido de Bonferroni), $n=4-5$ por grupo. 
Para um melhor entendimento do papel do AhR na indução da expressão proteica da IDO, foi realizada uma serie de experimentos utilizando camundongos WT e deficiente para este receptor. Já foi demonstrado que camundongos deficientes para o AhR são mais susceptíveis à sepse (Kimura et al., 2009). Assim, foram realizadas algumas mudanças no protocolo para indução de imunossupressão, uma vez que, a utilização do protocolo convencional poderia implicar na morte de todos os camundongos deficientes para o AhR mesmo após tratamento com antibiótico. Desta forma, a CLP foi realizada utilizando agulha com menor diâmetro em relação a utilizada no protocolo para indução da sepse grave convencional. Ainda, os camundongos foram tratados com a primeira dose de antibiótico $6 \mathrm{~h}$ após o procedimento cirúrgico e em seguida de 12 em 12 h até o segundo dia. Após a indução da sepse os camundongos foram acompanhados para registro da taxa de mortalidade. Em concordância com dados já publicados, a análise dos dados demonstrou uma sobrevida de aproximadamente $60 \%$ no grupo de camundongos deficientes para o $\mathrm{AhR}$, um pouco menor do que a encontrada para o grupo WT (Figura 15). 


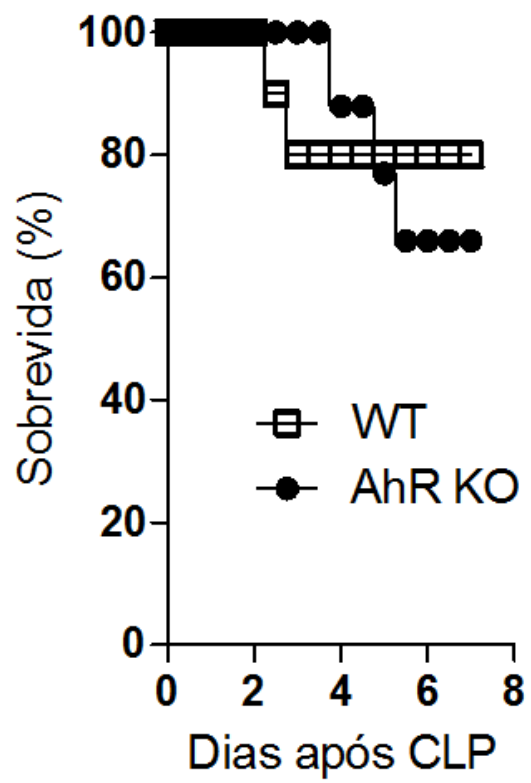

Figura 15: Avaliação da sobrevida em camundongos WT e deficientes para o AhR submetidos à sepse. Camundongos C57BL/6 WT ou deficientes para o AhR foram submetidos à CLP usando agulha $22 \mathrm{G}$ e tratados com antibiótico Ertapenen Sódico $(30 \mathrm{mg} / \mathrm{Kg})$, com a primeira dose $6 \mathrm{~h}$ após a sepse e na sequência de $12 \mathrm{em} 12 \mathrm{~h}$ até o segundo dia. A sobrevida foi avaliada de 12 em $12 \mathrm{~h}$ até o oitavo dia.

Resultados apresentados neste trabalho demostram que existe um aumento da expressão proteica da IDO no baço de camundongos que sobreviveram à sepse a partir do $7^{\circ}$ dia após a indução da sepse. Assim, em um segundo experimento, o baço de camundongos WT ou deficientes para o AhR foi coletado no $8^{\circ}$ dia após a indução da sepse e utilizado para avaliar a expressão proteica da IDO e do AhR, por meio da técnica de WB. Os dados demonstraram um aumento na expressão da IDO no baço dos camundongos WT submetidos à CLP, em relação aos camundongos naive (Figura 16). Por outro lado, não foi observado aumento na expressão proteica da IDO no baço dos camundongos deficientes para o AhR (Figura 16). 


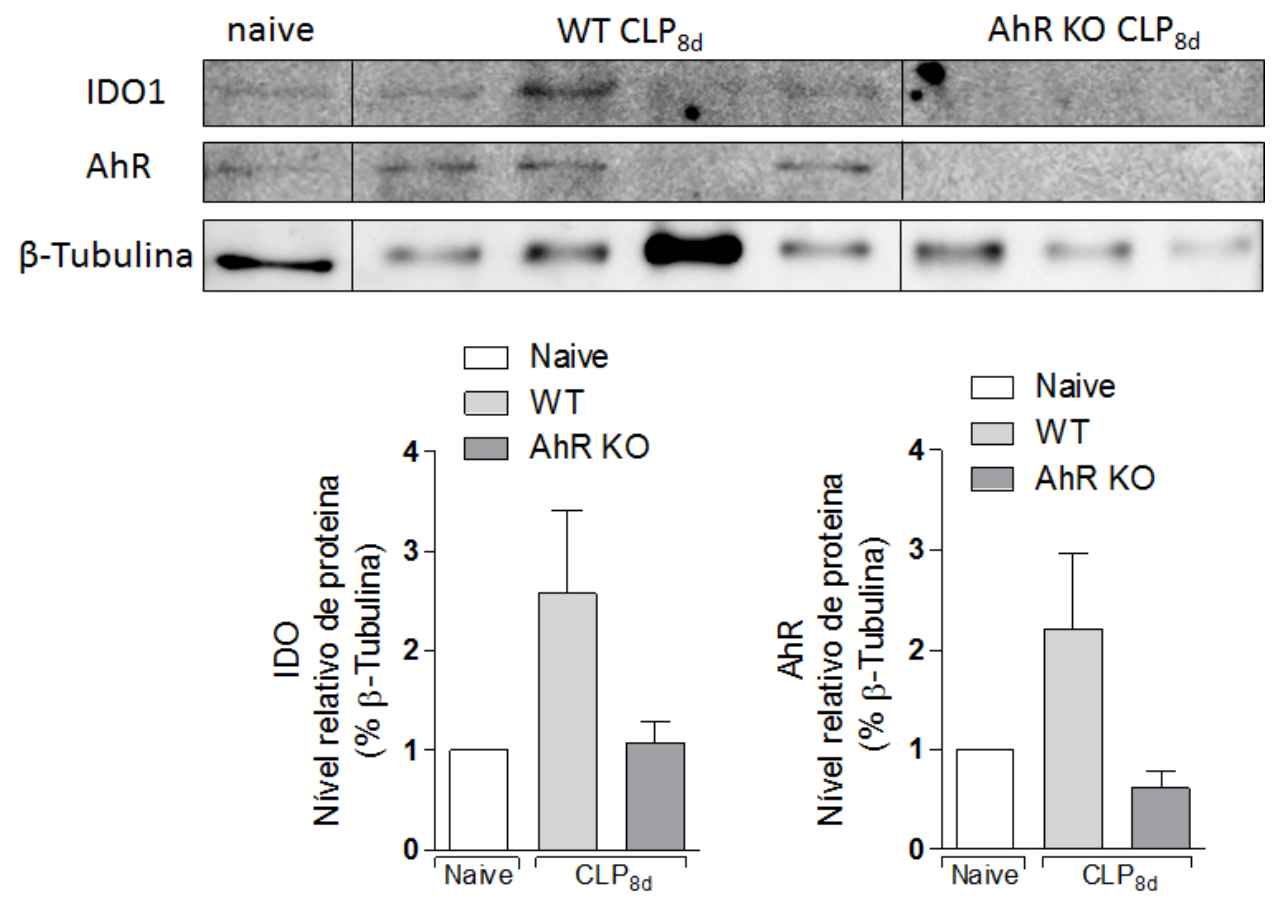

Figura 16: Papel do AhR na expressão proteica da IDO no baço de camundongos sobreviventes à sepse. Camundongos C57BL/6 WT ou deficientes para o AhR foram submetidos à CLP usando agulha $22 \mathrm{G}$ e tratados com antibiótico. No $8^{\circ}$ dia após a cirurgia, $\mathrm{O}$ baço foi coletado para avaliação da expressão proteica da IDO e do Ahr por meio da técnica de WB. Os resultados estão expressos como média \pm EPM em relação à expressão proteica da $\beta$ tubulina. $n=1-4$ por grupo.

Em um terceiro experimento, células recuperadas do baço dos camundongos que sobreviveram à sepse foram estimuladas com LPS ou CpG in vitro. Após $24 \mathrm{~h}$, as células foram recuperadas para avaliação da expressão proteica da IDO e do AhR. A análise dos resultados demonstrou que, existe uma maior expressão proteica da IDO nas células provenientes de animais pós-sepse tratadas com PBS, em relação aos animais naive. Esse resultado confirma a participação de mediadores produzidos durante a sepse na indução da expressão proteica da IDO (Figura 17 A). Como era de se esperar, a ativação das células proveniente de camundongos naive com LPS promoveu aumento na expressão da IDO (Fallarino et al., 2015). Por outro lado, não foi observado 
diferença na expressão proteica da IDO nas células provenientes de camundongos submetidos à sepse e reestimuladas com PBS ou LPS (Figura 17 A). Em relação ao estímulo com $\mathrm{CpG}$, foi observado aumento na expressão proteica da IDO nas células provenientes de camundongos naive. Por outro lado, não foi observado aumento da expressão da IDO nas células provenientes de animais que sobreviveram à sepse (Figura 17 A). Por fim, independente do estimulo utilizado, não foi observado aumento na expressão proteica da IDO em células provenientes de camundongos deficientes para o receptor $A h R$, o que suporta a hipótese da participação deste receptor na expressão da IDO, observada em camundongos que sobrevivem à sepse (Figura 17 A).

As mesmas amostras foram utilizadas para avaliar a expressão proteica do AhR. A análise dos dados demonstrou um aumento da expressão proteica deste receptor apenas nos grupos tratados com LPS (Figura 17 B). A coloração com Ponceau S dye demonstrou que a mesma quantidade de proteína foi aplicada no gel de poliacrilamida (Figura $17 \mathrm{C}$ ).

Nossos resultados demonstram que o aumento das Tregs observado em camundongos que sobrevivem à sepse depende da atividade enzimática da IDO. Também é importante ressaltar que os dados apresentados neste tópico sugerem que o AhR está envolvido com a expressão proteica da IDO induzida após a sepse. Assim, com o objetivo de confirmar nossos resultados, o linfonodo mesentério dos camundongos WT e deficientes para o AhR foi coletado para avaliação da frequência das Tregs. A análise dos resultados demonstrou um aumento na frequência das Tregs no linfonodo dos camundongos WT submetidos à sepse em relação aos camundongos naive. Por outro lado, não ocorreu aumento na frequência das Tregs no linfonodo dos camundongos 
deficientes para o AhR (Figura 18). Assim, os resultados suportam a hipótese da existência de uma via envolvendo AhR-IDO na expansão das Tregs e, consequente, desenvolvimento da imunossupressão induzida pela sepse.

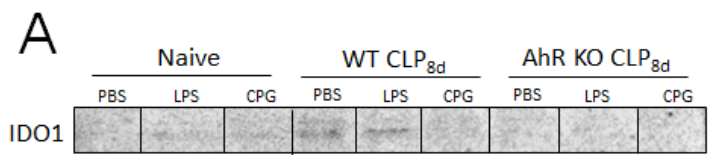

B AhR
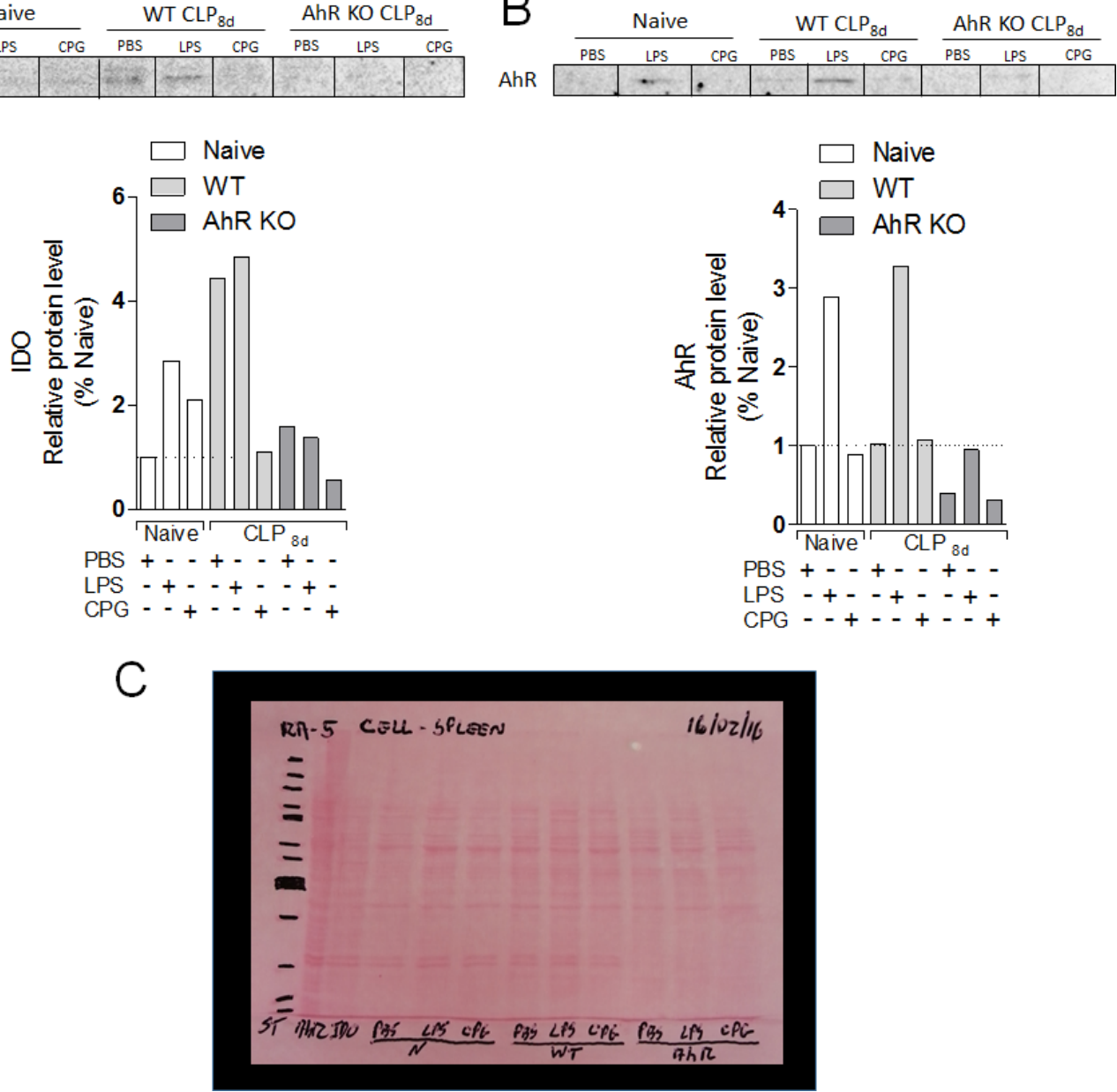

Figura 17: Papel do AhR na expressão proteica da IDO no baço de camundongos sobreviventes à sepse. Camundongos C57BL/6 WT ou deficientes para o AhR foram submetidos à CLP usando agulha $22 \mathrm{G}$ e tratados com antibiótico. No $8^{\circ}$ dia após a cirurgia,

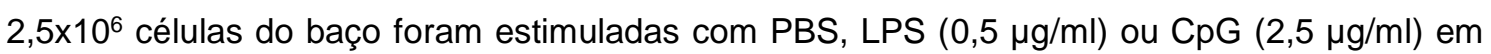
durante $24 \mathrm{~h}$. Após o intervalo da cultura as células foram coletadas e utilizadas para avaliação da expressão proteica da (A) IDO e do AhR (B) por meio da técnica de WB. Os resultados estão expressos em relação à expressão proteica da IDO ou do AhR encontrada nas células dos camundongos naive estimuladas com PBS. (C) Membrana de nitrocelulose corada com Ponceau $S$ dye para avaliação do processo de transferência de proteínas. Para camundongos naive foi utilizado um pool de células provenientes de 2 animais; para os camundongos que sobreviveram à sepse: WT um pool de 8 animais e deficientes para o AhR um pool de 6 animais. 
A

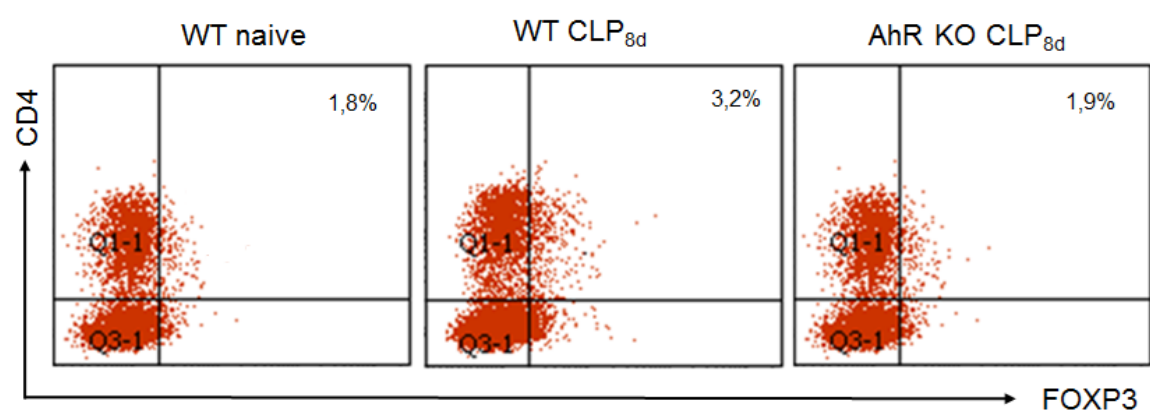

B

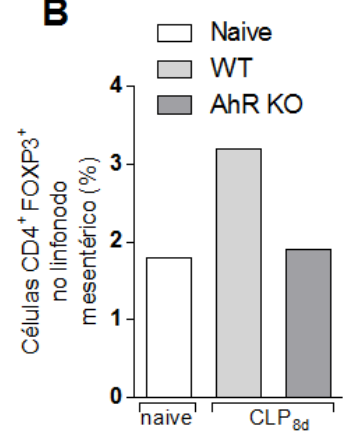

Figura 18: Avaliação do papel do AhR na expansão das Tregs observada em camundongos sobreviventes à sepse. Camundongos C57BL/6 WT ou deficientes para o AhR foram submetidos à CLP e tratados com antibiótico. No $8^{\circ}$ dia após CLP, o linfonodo mesentérico foi coletado e utilizado para avaliar a frequência das Tregs (células $\mathrm{CD}^{+}{ }^{+} \mathrm{FOXP}^{+}$) por meio da técnica de citometria de fluxo. (A) Dot plot representativo da porcentagem das Tregs no linfonodo mesentérico. (B) gráfico de barras representativo do dot plot. Os resultados estão expressos como média \pm EPM em relação à mediana da intensidade de fluorescência. $n=$ pool de células provenientes de 2 - 8 camundongos por grupo.

\subsection{Caracterização da célula responsável pela expressão da IDO no baço de camundongos sobreviventes à sepse}

Nossos resultados demonstraram que existe um aumento na expressão proteica da IDO no baço dos camundongos que sobreviveram à sepse. Assim, foram realizados alguns experimentos na tentativa de identificar qual ou quais subtipos celulares estariam expressando a enzima no contexto da imunossupressão induzida pela sepse. Dessa forma, além da marcação contra IDO, lâminas contendo cortes do baço foram preparadas e incubadas com anticorpos específicos contra a proteína B220, classicamente conhecida como marcador para linfócitos B. A análise das lâminas revelou algumas poucas

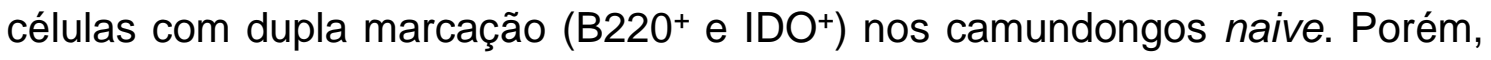
não foram observadas células com dupla marcação nos cortes provenientes de camundongos que sobreviveram á sepse, sugerindo que as células que expressam a IDO após a sepse não são linfócitos B (Figura 19 A e C). 
A

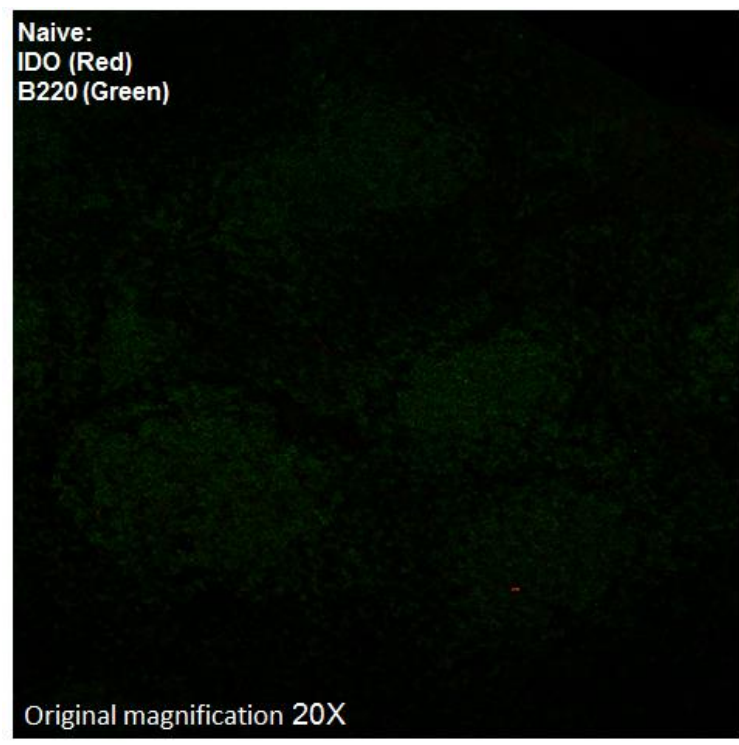

C

\section{Naive:}

IDO (Red)

B220 (Green)
B

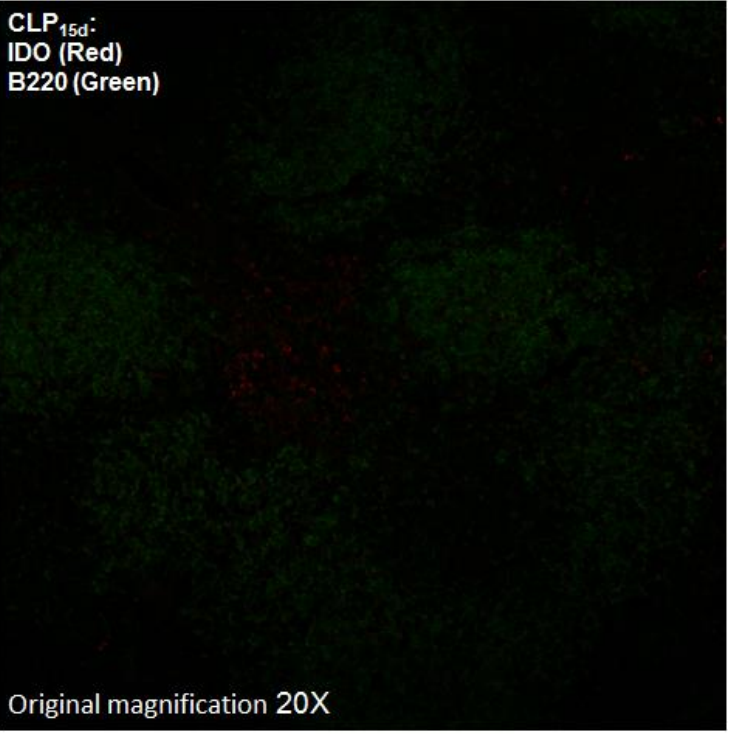

\section{D}

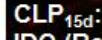

IDO (Red)

B220 (Green)

Original magnification $63 \mathrm{X}+$ digital zoon $5 \mathrm{X}$

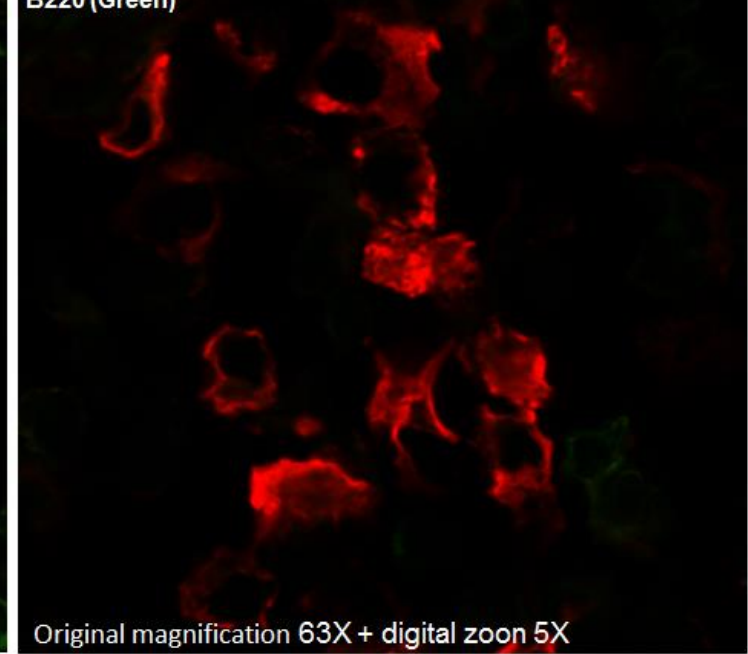

Figura 19: Identificação das células expressando IDO em camundongos que sobreviveram

à CLP. Para isso, camundongos C57BL/6 foram submetidos à CLP e tratados com antibiótico.

No $15^{\circ}$ dia após a cirurgia os animais foram perfundidos, o baço coletado e fatiado em lâminas de vidro. O sistema foi corado seguindo protocolo previamente padronizado e as imagens produzidas com auxílio de um microscópio confocal. Foram utilizados os anticorpos antiCD45/B220 Alexa Fluor 488 (verde) e anticorpo primário monoclonal anti-IDO 1, seguido de anticorpo secundário Alexa Flúor 594 (Vermelho). Para cada grupo, as imagens são representativas de dois animais distintos. 
Os resultados anteriores demonstraram que as células expressando a IDO estão localizadas fora da região que concentra os linfócitos B no baço. Assim, levando em consideração a organização celular no baço, foram realizados experimentos para avaliar se os linfócitos T CD4 ou as Células Dendríticas (DC) eram as responsáveis pela expressão da IDO. Primeiramente, foram realizados experimento com o objetivo de avaliar se as células expressando a IDO eram linfócitos T CD4. Para isso, além do anticorpo anti-IDO e anti-B220, as lâminas foram marcadas utilizando um anticorpo anti-CD4. A análise das lâminas demonstrou claramente que células $\mathrm{CD}^{+}$não são responsáveis pela expressão da IDO no baço de camundongos que sobreviveram à sepse, sugerindo que as células IDO+ não são linfócitos T CD4+ (Figura 20). 
A

B
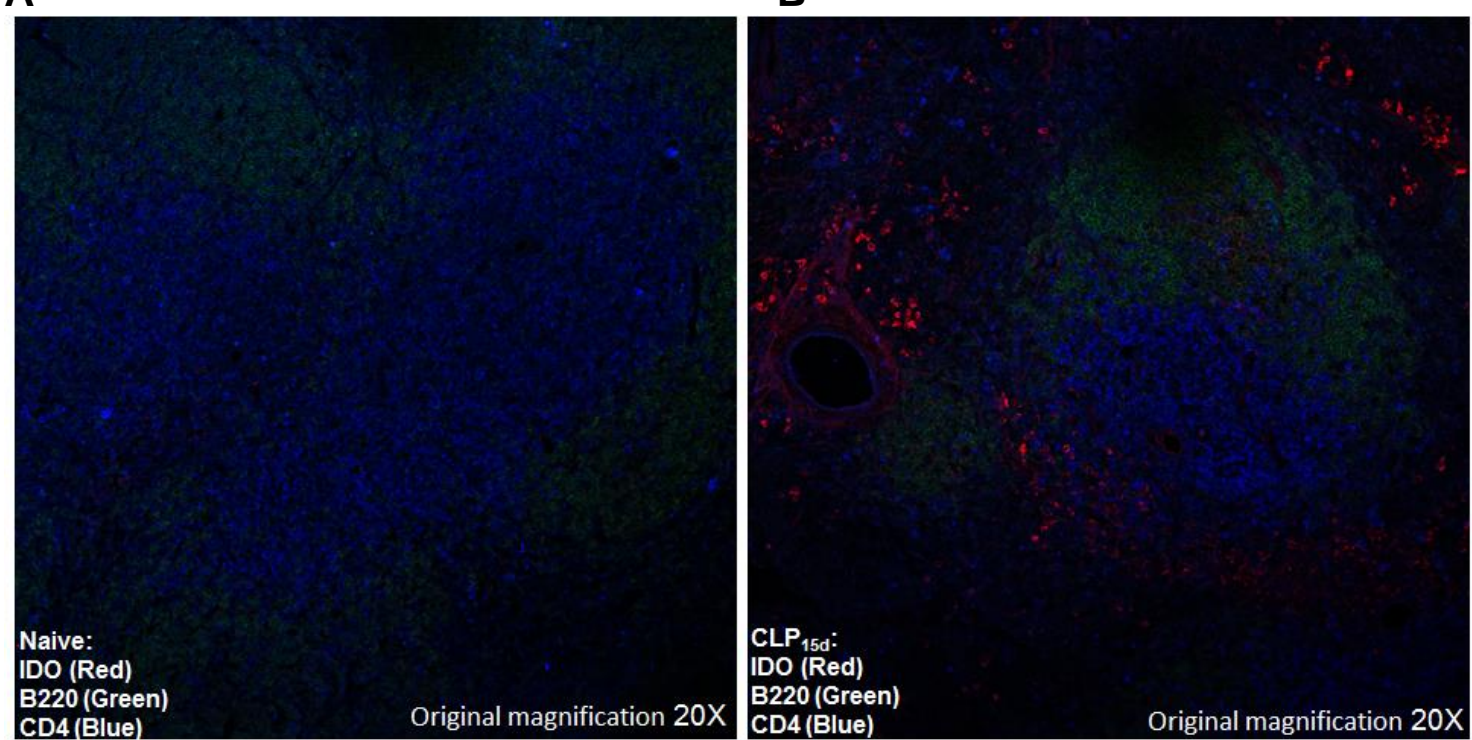

C

\section{Naive: \\ IDO (Red)}

$\mathrm{B} 220$ (Green)

CD4 (Blue)

D

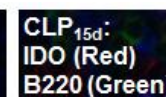

$\mathrm{B} 220$ (Green)

CD4 (Blue)

Original magnification $20 \mathrm{X}+$ digital zoon $5 \mathrm{X}$

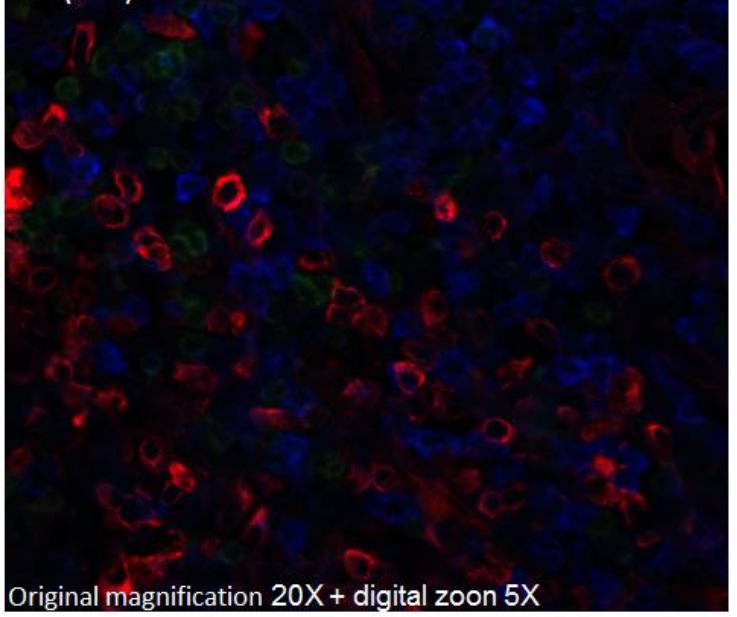

Figura 20: Identificação das células expressando IDO em camundongos que sobreviveram à CLP. Para isso, camundongos C57BL/6 foram submetidos à CLP e tratados com antibiótico. No $15^{\circ}$ dia após a cirurgia os animais foram perfundidos, o baço coletado e fatiado em lâminas de vidro. O sistema foi corado seguindo protocolo previamente padronizado e as imagens produzidas com auxílio de um microscópio confocal. Foram utilizados os anticorpos antiCD45/B220 Alexa Fluor 488 (verde), anti-CD4 Brilliant Violet 421 (azul) e anticorpo primário monoclonal anti-IDO 1, seguido de anticorpo secundário Alexa Flúor 594 (Vermelho). Para cada grupo, as imagens são representativas de dois animais distintos.

Por fim, foram realizados experimento para avaliar se DC estariam expressando IDO em camundongos que sobreviveram à sepse. Para isso, além do anticorpo anti-IDO, foram utilizados os anticorpos anti-B220 e anti-CD11C, um 
marcador expresso principalmente, porém não exclusivamente, pelas DC. Os resultados demonstram que existe co-localização entre a IDO e a proteína CD11c em camundongos que sobreviveram à sepse, sugerindo que as células responsáveis por expressar a IDO são DC (Figura 21).

A

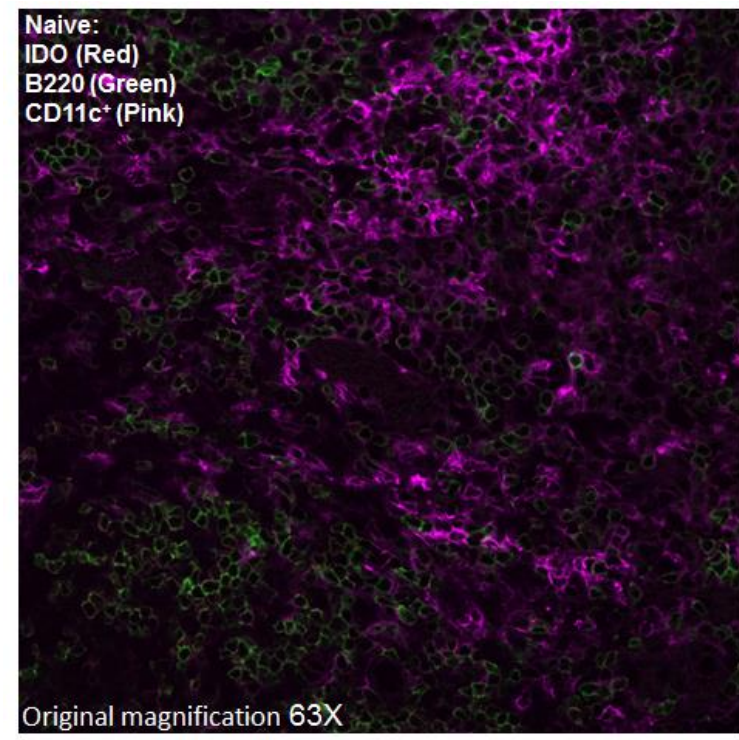

B

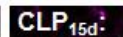

IDO (Red)

$\mathrm{B} 220$ (Green)

CD11c (Pink)

C

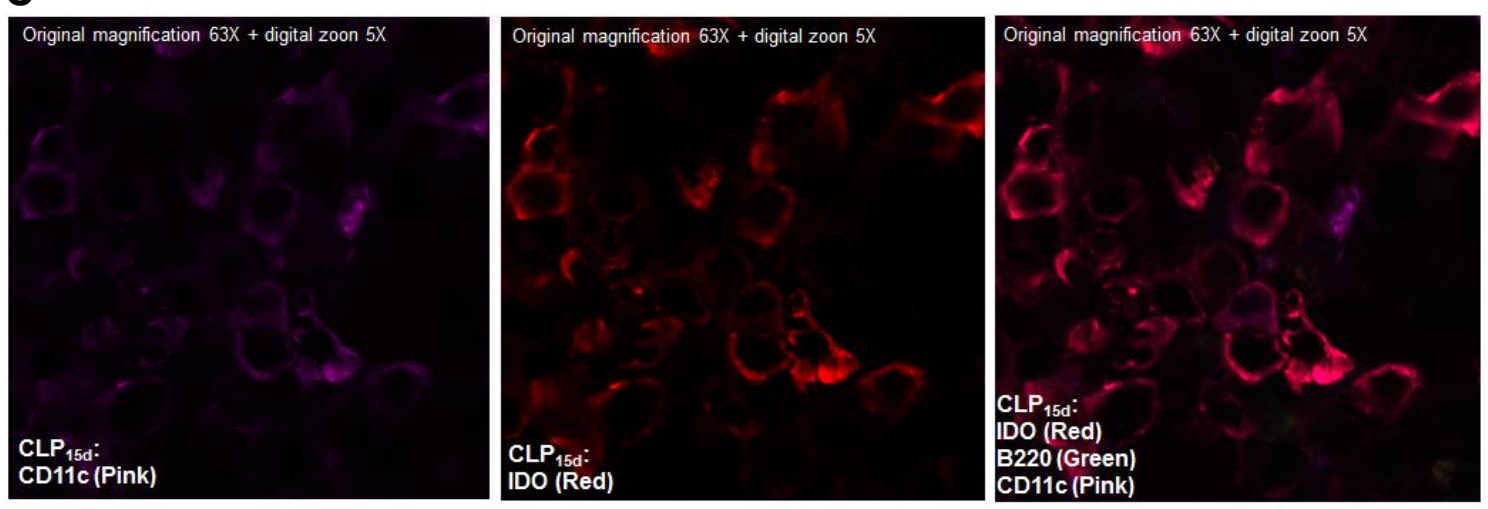

Figura 21: Identificação das células expressando IDO em camundongos que sobreviveram à CLP. Para isso, camundongos C57BL/6 foram submetidos à CLP e tratados com antibiótico. No $15^{\circ}$ dia após a cirurgia os animais foram perfundidos, o baço coletado e fatiado em lâminas de vidro. O sistema foi corado seguindo protocolo previamente padronizado e as imagens produzidas com auxílio de um microscópio confocal. Foram utilizados os anticorpos antiCD45/B220 Alexa Fluor 488 (verde), anti-CD11c Alexa flúor 647 (rosa) e anticorpo primário monoclonal anti-IDO 1, seguido de anticorpo secundário Alexa Flúor 594 (Vermelho). Para cada grupo, as imagens são representativas de dois animais distintos. 


\subsection{Avaliação da capacidade das células $\mathrm{CD}_{11 c^{+}}$provenientes de} camundongos que sobreviveram à sepse de induzir a diferenciação das Tregs

Até aqui, nossos resultados demonstraram que células CD11 $\mathrm{c}^{+}$presentes no baço de camundongos, passam a expressar a IDO após a sepse, por uma via que parece ser dependente da ativação do receptor AhR pela quinurenina.

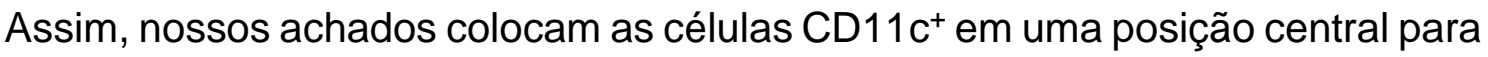
o desenvolvimento da imunossupressão. Dessa forma, foram realizados experimento com o objetivo de avaliar a capacidade das células CD11 ${ }^{+}$ originadas de camundongos que sobreviveram à sepse de induzir a diferenciação das Tregs.

Primeiramente, camundongos WT e deficientes para o AhR foram submetidos à sepse, conforme descrito no item 3.3.7. No $8^{\circ}$ dia após a CLP o baço foi coletado e células CD11 $\mathrm{c}^{+}$isoladas com auxílio de Beads Magnéticas. Por fim, as frações de células CD11c positivas e negativas foram utilizadas para avaliar a expressão gênica da IDO e do AhR, por meio da técnica de real timeRT PCR. Em concordância com resultados apresentados anteriormente, foi encontrado um aumento na expressão gênica da IDO na fração de células $\mathrm{CD}_{11 c^{+}}$em relação a fração negativa. Ainda, foi observada redução na expressão gênica da IDO na fração de células positivas provenientes do baço de camundongos deficientes para o AhR. Em linha com estas observações, foi encontrado um aumento da expressão gênica do AhR na fração de células CD11C (Figura 22). Dessa forma, a análise dos resultados suporta a hipótese de que a ativação do AhR é importante para expressão da IDO na fração de células $C D 11 \mathrm{C}^{+}$encontrada no baço de camundongos que sobrevivem à sepse. 
Um segundo experimento, foi realizado para avaliar a capacidade das células CD11c+ provenientes de animais que sobreviveram à sepse de induzir a diferenciação das Tregs. Para isso, células $\mathrm{CD}_{11 \mathrm{c}^{+}}$foram coletadas de camundongos WT naive ou no $8^{\circ}$ dia após a sepse e cultivadas com linfócitos $\mathrm{CD}^{+}{ }^{+} \mathrm{CD} 25^{-}$provenientes do baço de camundongos WT naive. Foi utilizada a proporção de 1 DC para 3 linfócitos. Quatro dias após o início da cultura as células foram recuperadas e utilizadas para avaliar a frequência das Tregs (células $\mathrm{CD}^{+}{ }^{+} \mathrm{FOXP3}^{+}$). A análise dos resultados demonstrou que as células $\mathrm{CD} 11 \mathrm{c}^{+}$provenientes de camundongos que sobreviveram à sepse possuem maior capacidade de induzir a diferenciação de linfócitos $T$ para um perfil regulador, quando comparadas as células $\mathrm{CD} 11 \mathrm{c}^{+}$provenientes de camundongos naive (Figura 23). 
A

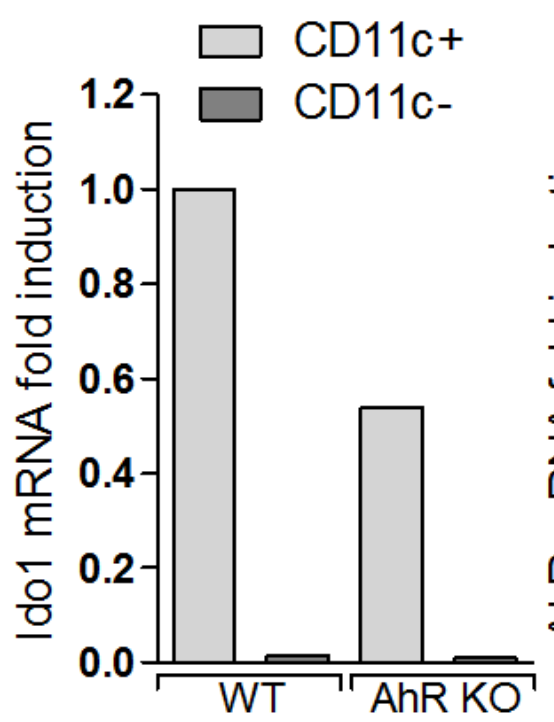

B

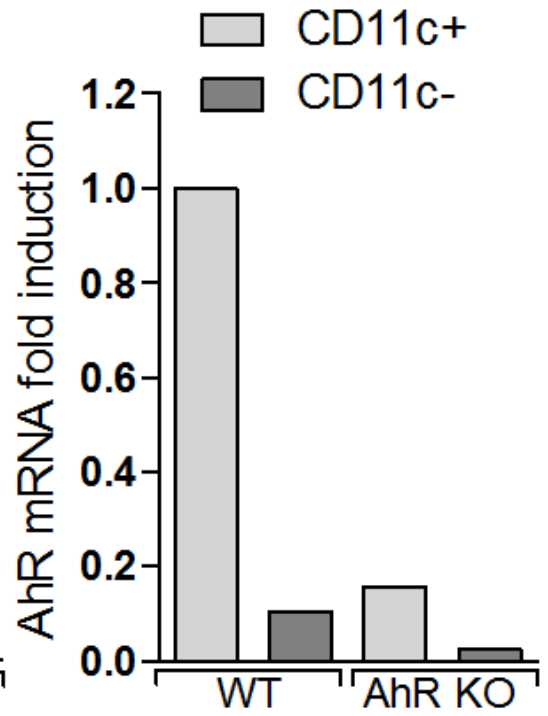

Figura 22: Avaliação da expressão gênica da IDO e do AhR em células CD11C+ provenientes do baço de camundongos que sobreviveram à sepse. Camundongos C57BL/6 WT ou deficientes para o AhR foram submetidos à CLP e tratados com antibiótico. No $8^{\circ}$ dia após a cirurgia, os animais foram eutanasiados e o baço utilizado para a separação de células CD11 C + com auxílio de magnetic beads. As frações contendo células positivas e negativas foram utilizadas para avaliar a expressão gênica da (A) IDO e do (B) AhR, por meio da técnica de real time-RT PCR. Os resultados estão expressos como média \pm EPM em relação à expressão gênica do GAPDH. Foi utilizado um pool de células provenientes de 8 camundongos WT e um pool de 6 camundongos deficientes para o AhR. 
A

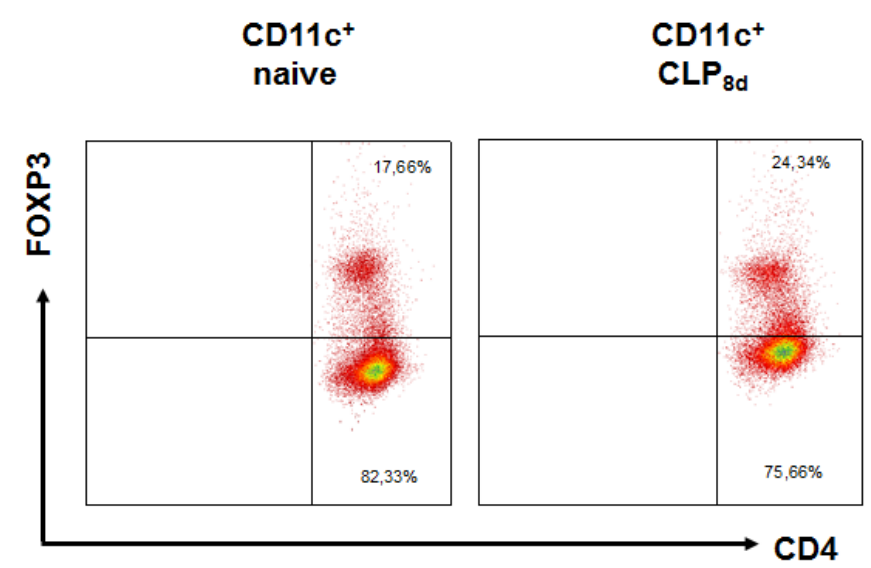

B

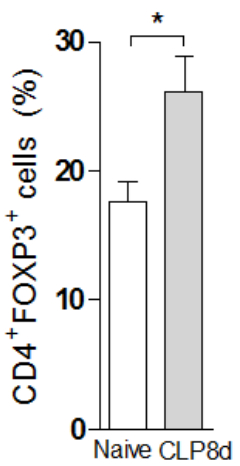

C

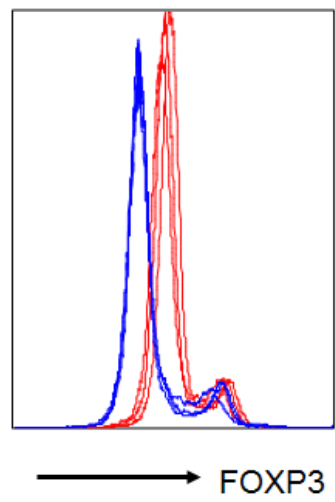

Figura 23: Avaliação da capacidade de células $\mathrm{CD}_{11 c^{+}}$provenientes do baço de camundongos que sobreviveram à sepse de induzir a diferenciação das Tregs. Camundongos C57BL/ 6 WT foram submetidos à CLP e tratados com antibiótico. No $8^{\circ}$ dia após a cirurgia, os animais foram eutanasiados e o baço utilizado para a separação de células CD11 $\mathrm{C}^{+}$ com auxílio de magnetic beads. Um grupo de camundongos naive foi utilizado para coleta de células $\mathrm{CD} 11 \mathrm{C}^{+}$além de células $\mathrm{CD} 4^{+} \mathrm{CD} 25^{-}$. As frações contendo células $\mathrm{CD} 11 \mathrm{C}^{+}$provenientes de camundongos que sobreviveram à sepse ou de camundongos naive foram cultivadas com células CD4+ CD25- com adição de anti-CD3, anti-CD28. Quatro dias após o início da cultura, as células foram recuperadas para avaliação da frequência das Tregs (células CD4+ CD25-). (A) Dot plot representativo da porcentagem das Tregs no baço. (B) histograma representativo do dot plot. (C) gráfico de barras representativo do dot plot. Os resultados estão expressos como média \pm EPM em relação à mediana da intensidade de fluorescência. * $p<0,05$; (ANOVA seguido de Bonferroni). $n=$ pool de células provenientes de 3 camundongos naive ou 3 camundongos submetidos à sepse. Cada pool foi pipetado em triplicata em placa de 48 wells. 


\section{DISCUSSÃO}

Estudos que acompanharam pacientes após a alta hospitalar, demonstraram que indivíduos que sobreviveram a um quadro de sepse, apresentaram maior taxa de mortalidade quando comparados aos pacientes originalmente internados por outros motivos. Estes dados suportam a hipótese de que a sepse grave está associada ao desenvolvimento de um quadro de imunossupressão caracterizado pela incapacidade do sistema imune em montar uma resposta protetora efetiva (Quartin et al., 1997; Weycker et al., 2003; Hotchkiss et al., 2013a). Apesar de avanços obtidos nas últimas décadas, os fatores associados ao desenvolvimento da imunossupressão induzida pela sepse ainda não foram completamente esclarecidos. Assim, um dos objetivos do nosso grupo de pesquisa é estudar os mecanismos associados ao desenvolvimento da imunossupressão induzida pela sepse.

Para a realização deste trabalho, foi utilizado o modelo experimental de CLP. Este é considerado o padrão ouro para o estudo da sepse polimicrobiana, uma vez que, mimetiza muitos dos sinais e sintomas observados na clínica (Dejager et al., 2011). Neste trabalho, camundongos foram submetidos a uma sepse grave, caracterizada por uma taxa de mortalidade de $100 \%$ ainda nas primeiras horas após a CLP. Para evitar a morte de todos dos camundongos, os animais submetidos a sepse foram tratados com antibiótico, o que proporcionou uma taxa de sobrevida de aproximadamente 50\%. É interessante ressaltar que, a porcentagem de sobrevida encontrada após o tratamento dos camundongos com antibiótico é semelhante a encontrada na clínica (Cohen et al., 2015), 
sugerindo que o modelo de CLP é uma boa ferramenta para o estudo da sepse e suas consequências.

Já foi demonstrado que camundongos que sobrevivem a uma sepse grave apresentam um comprometimento em controlar infeções secundárias e o crescimento tumoral (Cavassani et al., 2010; Nascimento et al., 2010; Mota et al., 2016). Resultados já publicados demonstram que pacientes que sobreviveram à sepse são mais susceptíveis a infecções secundárias por patógenos oportunistas, além disso, existem dados sugerindo que pacientes que sobreviveram à sepse apresentam uma maior probabilidade para o desenvolvimento de tumores (Hotchkiss et al., 2013a; Hotchkiss et al., 2013b). Dessa forma, para avaliar se os camundongos que sobrevivera à sepse, desenvolveram um quadro de imunossupressão, os animais foram desafiados com uma linhagem de melanoma murino. A análise dos resultados confirmou que existe um maior crescimento tumoral nos camundongos que sobreviveram á sepse em relação aos camundongos naive, sugerindo que, o sistema imune dos animais que sobreviveram à sepse apresenta uma menor capacidade de montar uma resposta antitumoral eficiente, evidenciando assim, o desenvolvimento de um estado de imunossupressão.

Já foi demonstrado que o desenvolvimento da imunossupressão que ocorre após a sepse depende do aumento na frequência das Tregs, (Cavassani et al., 2010; Nascimento et al., 2010). Também foi demonstrado que existe um aumento de Tregs no baço de humanos que morreram em decorrência de complicações induzidas pela sepse (Boomer et al., 2011). Dessa forma, para avaliar se o quadro de imunossupressão apresentado pelos camundongos que sobreviveram à sepse estava associado às Tregs, a frequência deste subtipo 
celular foi avaliada no baço de camundongos no $15^{\circ}$ dia após a indução da sepse.

Em conformidade com dados já publicados, foi encontrado um aumento na frequência das Tregs no baço dos camundongos que sobreviveram à sepse, em relação aos camundongos naive. Este resultado sugere que a incapacidade do sistema imune dos camundongos que sobreviveram à sepse em montar uma resposta antitumoral eficiente está relacionada com a expansão das Tregs. Além disso, foi observado um aumento crescente na concentração da citocina antiinflamatória IL-10 no pulmão dos camundongos submetidos à sepse. Sabe-se que, um dos mecanismos imunossupressores utilizados pelas Tregs é a produção desta citocina (Shevach, 2009). Assim, os resultados sugerem que as Tregs encontradas no organismo dos camundongos que sobreviveram à sepse estão produzindo IL-10, contribuindo para a redução da capacidade efetora do sistema imune, e consequentemente, para a instalação do quadro de imunossupressão.

Apesar dos avanços alcançados nos últimos anos, os mecanismos relacionados à expansão das Tregs induzida pela sepse, ainda não foram completamente esclarecidos. Nesse contexto, vários trabalhos vêm demonstrando que a enzima IDO possui propriedades imunomoduladoras (Munn et al., 2013). Uma vez expressa, a IDO atua promovendo o metabolismo oxidativo do triptofano, gerando como produto principal a quinurenina, (Taylor et al., 1991; Munn et al., 2013). Inúmeros trabalhos vêm demonstrando que a quinurenina está associada ao desenvolvimento das Tregs e de um estado tolerogênico em diferentes células do sistema imune (Fallarino et al., 2006; Mezrich et al., 2010; Nguyen et al., 2010; Bessede et al., 2014). Sabe-se que a 
quinurenina é substrato para uma enzima chamada Quinurenina 3monooxigenase (KMO), que juntamente com a IDO, alimentam uma extensa cascata de moléculas biologicamente ativas (Stone et al., 2002; Vecsei et al., 2013). Assim, apesar das evidencias demonstrando as propriedades tolerogênicas e imunossupressoras da IDO e de seu metabólito, ainda não existem trabalhos avaliando seu papel na expansão das Tregs que ocorre após a sepse greve.

Para avaliar o envolvimento da IDO no desenvolvimento da imunossupressão induzida pela sepse, foram realizados experimento para avaliar a expressão proteica desta enzima em diferentes momentos após a indução da sepse. Nossos resultados demonstraram que existe um aumento na expressão proteica da IDO no baço dos camundongos que sobreviveram à sepse a partir do $7^{\circ}$ dia após a CLP. Também foi observado um aumento da expressão proteica da IDO no pulmão a partir do $3^{\circ}$ dia após a CLP. Confirmando os resultados anteriores, também foi encontrado um aumento na expressão proteica da IDO por meio da técnica de imunofluorescencia. A análise dos dados demonstrou que existe uma população celular expressando a IDO no baço quinze dias após a indução da sepse.

Sabe-se que mediadores inflamatórios produzidos durante a sepse, como por exemplo, IL-1, IL-2, TNF, interferons (IFN)- $\alpha, \beta$ e $\gamma$, bem como, LPS e CpG podem induzir a expressão da IDO (Taylor et al., 1991; Puccetti, 2007). Apesar disso, não foi identificado aumento na expressão proteica da IDO no $1^{\circ}$ e $3^{\circ}$ dia após a CLP. Dados publicados recentemente demonstram que existe um aumento da expressão proteica da IDO no plasma, pulmão e fígado de porcos 3 e $6 \mathrm{~h}$ após desafio com LPS, intervalos não avaliados em nosso estudo. Por 
outro lado, os valores da expressão proteica da enzima retornaram a valores basais 24 h após o desafio com LPS (Wirthgen et al., 2014), o que suporta nossos dados, uma vez que, não encontramos um aumento na expressão proteica da IDO no primeiro dia após a sepse. Dessa forma, a análise dos dados apresentados neste trabalho, associados aos encontrados na literatura, permitem sugerir que existe um aumento passageiro da expressão proteica da IDO nas primeiras horas após a sepse, o qual retorna a um nível basal rapidamente. Ainda, nossos dados demonstram que existe um aumento tardio na expressão proteica da IDO no baço de camundongos que sobreviveram a sepse ativado por mecanismos ainda desconhecidos.

Especificamente em relação à enzima $\mathrm{KMO}$, nossos resultados demonstraram uma redução em sua expressão gênica e proteica no baço dos camundongos que sobreviveram à sepse, já nos primeiros dias após a CLP. Também foi verificado redução na expressão proteica da KMO no pulmão, o que ocorreu apenas no $15^{\circ}$ após a CLP. A análise dos dados apresentados até aqui, permite sugerir que o aumento na expressão proteica da IDO e a redução da expressão gênica e proteica da KMO possam levar ao acúmulo de quinurenina no baço e pulmão dos camundongos que sobreviveram á sepse. Além disso, já foi demonstrado que um dos efeitos imunomoduladores da IDO está associado a diferenciação das Tregs por meio da liberação da quinurenina (Fallarino et al., 2006; Mezrich et al., 2010; Nguyen et al., 2010). Assim, nossos resultados suportam a hipótese do envolvimento da IDO na expansão das Tregs observada em camundongos que sobreviveram a sepse, o que por sua vez, estaria associado ao desenvolvimento do quadro de imunossupressão. 
Dados encontrados na literatura demonstram que existe um aumento da expressão proteica da IDO em leucócitos circulantes e da razão quinurenina/triptofano no soro de pacientes sépticos, sendo que, o aumento dessa razão foi associado a um mau prognóstico da doença (Huttunen et al., 2010; Ploder et al., 2010; Tattevin et al., 2010; Darcy et al., 2011). Dessa forma, foram realizados experimentos para avaliar a razão quinurenina/triptofano no soro de camundongos submetidos a uma sepse moderada em relação a animais submetidos a uma sepse letal. Nossos resultados estão de acordo com dados publicados na literatura e demonstraram que existe um aumento na razão quinurenina/ triptofano apenas no soro de camundongos submetidos a uma sepse letal, sugerindo um papel prejudicial da quinurenina durante a sepse.

É importante destacar que, a quinurenina apresenta cinética de eliminação de primeira ordem. Ainda, camundongos desafiados com uma única dose de LPS, apresentaram um aumento de 3 vezes na concentração de quinurenina no soro e meia vida de eliminação de 4 h (Takikawa et al., 1986). Dessa forma, para comprovar o envolvimento da quinurenina no agravamento da sepse, camundongos foram submetidos a uma sepse moderada pelo modelo de CLP e tratados com quinurenina de 24 em 24 horas, durante 7 dias.

O resultado confirmou a participação da quinurenina no agravamento da sepse, uma vez que, camundongos submetidos a um sepse moderada e tratados com quinurenina apresentaram taxa de mortalidade semelhante àquela encontrada em camundongos submetidos a uma sepse grave, demonstram que, assim como em pacientes, um aumento da relação quinurenina/triptofano está associado ao agravamento da sepse. Ainda, diante da relação entre a gravidade da sepse e o desenvolvimento do quadro de imunossupressão (Hotchkiss et al., 
2013a), os resultados sugerem que a quinurenina produzida durante a fase aguda da sepse possa ser um fator associado com o desenvolvimento da imunossupressão induzida pela a sepse.

Neste momento, é importante pontuar que, não foi identificado aumento na expressão proteica da IDO no $3^{\circ}$ dias após a sepse, intervalo no qual, existe aumento na relação quinurenina/triptofano no soro de camundongos submetidos a uma sepse letal. Esta pode parecer uma contradição entre nossos resultados, porém, é necessário ressaltar que existem outras enzimas que também podem converter o triptofano em quinurenina. Um trabalho recente demonstrou que a principal responsável pelo aumento da razão quinurenina/triptofano no soro de camundongos desafiados com LPS é TDO2 (Bessede et al., 2014; Wirthgen et al., 2015), uma enzima expressa no fígado, que também pode promover a metabolização do triptofano em quinurenina. De fato, Bessede e colaboradores demonstraram que existe um aumento na razão quinurenina/triptofano em camundongos deficientes para a enzima IDO após desafio com LPS. Porém, esse aumento foi abolido quando os animais deficientes para a IDO, que receberam o desafio com LPS, foram tratados com um inibidor da enzima TDO 2. O mesmo trabalho demonstrou que, um segundo desafio com LPS promoveu um aumento na IDO, o que foi relacionado ao quadro de tolerância ao LPS (Bessede et al., 2014). Assim, nós acreditamos que durante a fase aguda da sepse, a principal enzima responsável por promover a metabolização do triptofano seja a TDO 2. Sendo que, a IDO teria um papel de destaque em uma etapa mais tardia (Bessede et al., 2014). Assim, seria interessante a realização de um estudo com o objetivo de avaliar o papel da TDO2 durante a fase aguda da sepse. 
Resultados interessantes foram encontrados nos experimentos realizados com o objetivo de avaliar atividade enzimática da IDO. Foi identificado que existe um aumento tardio na atividade da enzima apenas no baço de camundongos que sobreviveram à sepse. Esse dado é interessante e sugere que a quinurenina estaria atuando em dois momentos. Primeiramente, existe a produção da quinurenina, possivelmente, como resultado da ação enzimática da TDO 2 durante a fase aguda da sepse. $O$ primeiro aumento da razão quinurenina/triptofano, pode estar relacionado a gravidade da sepse, o que por sua vez, é um fator sabidamente associado ao desenvolvimento do quadro de imunossupressão (Hotchkiss et al., 2013a). Em um segundo momento, os dados sugerem a existência de um aumento da relação quinurenina/triptofano no microambiente do baço, importante órgão para ativação e diferenciação das Tregs.

Nosso próximo objetivo foi demonstrar o envolvimento da IDO no desenvolvimento da imunossupressão induzida pela sepse. Sabe-se que, camundongos que sobrevivem á sepse desenvolvem um quadro de imunossupressão caracterizada pela incapacidade de montar uma resposta antitumoral eficiente (Cavassani et al., 2010; Mota et al., 2016). Assim, para avaliar a existência de uma relação entre a IDO e o desenvolvimento da imunossupressão, camundongos que sobreviveram a sepse foram tratados durante 10 dias com o composto DL-1MT, um inibidor competitivo da IDO.

A avaliação do volume tumoral demonstrou um maior crescimento do melanoma nos camundongos submetidos à CLP e tratados com salina, quando comparados aos camundongos naive. Esse resultado está de acordo com dados encontrados na literatura, confirmando que modificações ocorridas durante a 
sepse promoveram o desenvolvimento de um microambiente favorável ao crescimento tumoral (Cavassani et al., 2010; Nascimento et al., 2010; Mota et al., 2016). Por outro lado, a análise dos dados demonstrou que, o tratamento dos camundongos com 0 inibidor da IDO durante 0 desenvolvimento da imunossupressão, foi efetivo em reduzir o crescimento tumoral em relação aos camundongos submetidos à CLP e tratados com salina. Este resultado é extremante interessante e confirma a relação entre a atividade enzimática da IDO e o desenvolvimento da imunossupressão induzida após a sepse.

Já foi demonstrado que a expansão das Tregs está relacionada com o desenvolvimento da imunossupressão induzida pela sepse (Cavassani et al., 2010; Nascimento et al., 2010). Outros grupos demonstraram que, tanto a depleção de triptofano como a produção de quinurenina promovidos pela IDO, estão envolvidos com a diferenciação das Tregs (Fallarino et al., 2006; Mezrich et al., 2010; Nguyen et al., 2010). Assim, foram realizados experimentos para avaliar se a redução do grau de imunossupressão observado em camundongos tratados com o inibidor da IDO, estaria relacionado com a redução na diferenciação das Tregs. A análise dos resultados demonstrou que existe um aumento na frequência das Tregs no baço dos camundongos submetidos à sepse e tratado com salina. Por outro lado, nós encontramos uma redução na frequência das Tregs no baço dos animais submetidos à sepse e tratados com o inibidor da IDO indicando que sua atividade enzimática está envolvida com a expansão das Tregs. É importante ressaltar que, a IDO é uma molécula versátil que além da função enzimática clássica, também pode atuar como fator de transcrição, em uma via associada com a manutenção de sua expressão (Pallotta et al., 2011; Bessede et al., 2014). Dessa forma, nossos resultados são 
interessantes e associam a atividade enzimática da IDO com a expansão das Tregs que ocorre após a sepse, porém seria importante investigar o papel não enzimático da IDO neste contexto.

Foi demonstrado que a inibição da atividade enzimática da IDO reduziu o grau de imunossupressão dos camundongos que sobreviveram à sepse por um mecanismo dependente da redução na frequência das Tregs no baço. Assim, os próximos passos no desenvolvimento deste trabalho foram dados na tentativa de entender quais mecanismos estariam relacionados à resposta antitumoral mais eficiente observada nos camundongos tratados com o inibidor da IDO.

Assim, foram realizados experimentos para avaliar a frequência de uma população celular denominada myeloid-derived suppressor cells (MDSC). As MDSC são originadas a partir de células mielóides imaturas da medula óssea (IMCs). Em animais naive, as IMCs são rapidamente diferenciadas em monócitos ou células dendríticas. Porém, em determinadas circunstâncias, como doenças infecciosas, câncer ou sepse a diferenciação das IMCs em células maduras é reduzida (Delano et al., 2007). Além disso, as IMCs passam a expressar altos níveis das enzimas arginase (ARG) e óxido nítrico sintase induzida (iNOS). Também passam a produzir altos níveis de espécies reativas de oxigênio, deixando de ser classificadas como IMCs, sendo classificadas como MDSCs (Gabrilovich et al., 2009). Assim, o termo myeloid-derived suppressor cells representa uma população heterogênea de células, sendo que, as mais conhecidas são a granulocítica $\left(C D 11 b^{+}\right.$Ly6G+ $)$e a monocítica $\left(C D 11 b^{+}\right.$Ly6C $\left.C^{+}\right)$ (Youn et al., 2008).

Funcionalmente, foi demonstrado que as MDSC são capazes de modular a produção de citocinas em macrófagos (Sinha et al., 2007), além de apresentar 
alta capacidade supressora sobre linfócitos $T$, por um mecanismo que depende principalmente da redução na disponibilidade do aminoácido arginase no microambiente celular (Rodriguez et al., 2002; Bronte et al., 2005). As MDSC foram observadas pela primeira vez em pacientes com Câncer (Gabrilovich et al., 2009), e vários estudos vem demonstrando que elas possuem um importante papel nos mecanismos de progressão e escape tumoral (Murdoch et al., 2008).

Nossos resultados demonstraram que existe um aumento seletivo na frequência das células $C D 11 b^{+} \mathrm{Ly}_{6 \mathrm{G}}+$ no baço dos camundongos submetidos à sepse e tratados com salina quando comparados aos camundongos naive. $O$ aumento seletivo na frequência das células $\mathrm{Ly}_{6 \mathrm{G}}{ }^{+}$permite especular que essa população seja mais sensível a ação de mediadores liberados direta ou indiretamente pelas células tumorais, quando comparadas às células Ly6C+ .

A inibição da atividade enzimática da IDO durante o desenvolvimento da imunossupressão promoveu redução na frequência das células $L y 6 G^{+}$no baço dos camundongos. É interessante ressaltar que, possivelmente, a redução na frequência das células $C D 11 b^{+} \mathrm{Ly}_{6 \mathrm{G}}+$, observada apenas em camundongos tratados com DL-1 MT, não esteja relacionada diretamente com a inibição da IDO e sim com o menor crescimento das células tumorais. Os camundongos tratados com inibidor da IDO apresentaram menor expansão de Tregs quando comparados aos camundongos tratados com salina. Assim, é possível sugerir que, um menor número de Tregs favoreceu o desenvolvimento de um microambiente menos favorável ao crescimento tumoral, o que poderia justificar a menor diferenciação das células $\mathrm{CD} 11 \mathrm{~b}^{+} \mathrm{Ly} 6 \mathrm{G}^{+}$induzida pelas células tumorais. 
Sabe-se que um dos mecanismos relacionados à ativação de uma resposta imune antitumoral efetiva, depende da produção de IFN-Y pelos linfócitos T CD8+ (Powell et al., 2004; Hadrup et al., 2013). Os resultados apresentados neste trabalho demonstram que animais submetidos à sepse e tratados com salina não apresentam aumento na frequência das células CD8+ produtoras de IFN-Y no linfonodo drenante da região tumoral, evidenciado que o sistema imune desses animais não foi capaz de montar uma resposta antitumoral eficiente. Por outro lado, os resultados demonstram um aumento na frequência de células $\mathrm{CD}^{+} \mathrm{IFN}-Y^{+}$no linfonodo dos camundongos tratados com DL-1 MT, sugerindo que o sistema imune desses animais foi mais competente em montar uma resposta antitumoral eficiente.

Nossos resultados permitem sugerir que, o aumento da expressão proteica da IDO no baço de camundongos que sobrevivem à sepse está associado ao desenvolvimento do quadro de imunossupressão, por um mecanismo que depende da diferenciação das Tregs. O tratamento com o inibidor da IDO reduziu a expansão das Tregs, melhorando a capacidade do sistema imune promover o controle do crescimento tumoral por um mecanismo dependente da redução da frequência de células MDSC (CD11b+ Ly6G+), e de um aumento na frequência de células CD8+ IFN-ץ.

Apesar das respostas encontradas durante o desenvolvimento deste trabalho, a análise dos resultados levantou uma importante questão. Qual ou quais mecanismos estariam envolvidos com o aumento da expressão proteica da IDO observada nos camundongos que sobreviveram à sepse?

Dados produzidos por nosso grupo demonstraram que existe um aumento na concentração das citocinas IL-4, IL-13 e IL-33 em camundongos que 
sobrevivem a uma sepse grave, o que foi associado a polarização de macrófagos para um perfil M2 e com a expansão das Tregs. Ainda, apesar dos resultados apresentados neste trabalho indicarem uma relação entre a IDO e a expansão das Tregs durante o desenvolvimento da imunossupressão, ainda não existem dados na literatura demonstrando o papel da IDO na diferenciação de macrófagos para um perfil M2. Dessa forma, foram realizados experimentos para avaliar a relação entre a atividade enzimática da IDO e a diferenciação de macrófagos M2 no contexto da imunossupressão induzida pela sepse.

Primeiramente, foram realizados experimentos que demonstraram um aumento progressivo na concentração das citocinas IL4, IL-13 e IL-33 no pulmão de camundongos que sobreviveram à sepse, o que foi relacionado com a maior frequência de macrófagos M2 na cavidade peritoneal dos animais. Porém, o tratamento de camundongos que sobreviveram à sepse com DL-1MT não alterou a frequência de macrófagos M2 no lavado peritoneal dos animais, demonstrando que a atividade enzimática da IDO não está envolvida com a diferenciação de macrófagos para um perfil M2 em animais que sobrevivem à sepse.

Dados publicados demonstram que os interferons (IFN)- $\alpha, \beta$ e y são potentes indutores da expressão da IDO (Taylor et al., 1991; Puccetti, 2007). Dessa forma, nossa hipótese seria que interferon produzido durante o intenso quadro inflamatório que caracteriza a sepse, estariam promovendo o aumento da expressão proteica da IDO e contribuindo para expansão das Treg e consequentemente com a instalação do quadro de imunossupressão. Assim, foram realizados experimentos com o objetivo de avaliar o papel do interferon $Y$ na expansão das Tregs induzida pela sepse. 
Nossos resultados demonstraram que a falta da citocina IFN- $\gamma$ não reduziu a frequência das Tregs no baço dos camundongos que sobreviveram à sepse. De fato, os camundongos IFN-y KO submetidos à CLP apresentaram maior frequência das Treg quando comparados aos camundongos WT submetidos à CLP. Este resultado sugere que a falta do IFN-Y não reduziu a expressão da IDO, uma vez que, os dados apresentados neste trabalho demonstram que sua atividade enzimática está envolvida com a diferenciação das Tregs observada durante o desenvolvimento da imunossupressão. É importante ressaltar que, nossos dados não descartam a participação dos interferons $\alpha$ e $\beta$ nesse processo.

Resultados ainda não publicados por nosso grupo demonstram que existe um aumento da expressão proteica do AhR durante a fase inicial da sepse. Também foi demonstrado por outros grupos que a ativação do receptor AhR está associada ao aumento da expressão gênica da IDO (Mezrich et al., 2010; Nguyen et al., 2010; Quintana et al., 2013). Por fim, dados apresentados neste trabalho demonstram que no terceiro dia após a sepse existe um aumento da concentração sérica de quinurenina, cuja atividade está associada a diferenciação das Tregs por meio da ativação do AhR (Mezrich et al., 2010). Assim, foi realizada uma bateria de experimentos com o objetivo de avaliar a participação do AhR na expressão da IDO em camundongos que sobreviveram á sepse.

Os resultados demonstram um aumento na expressão proteica do AhR já nos primeiros dias após à sepse, mesmo momento em que foi identificado um aumento da razão quinurenina/triptofano. Os dados suportam a hipótese de que a quinurenina produzida durante a fase aguda da sepse poderia ativar o receptor 
AhR, o que por sua vez, estaria associado ao aumento da expressão da IDO observado no baço de camundongos que sobreviventes à sepse.

Para um melhor entendimento do papel do AhR na indução da expressão proteica da IDO em camundongos que sobrevivem à sepse, foram realizados experimentos utilizando camundongos deficiente para este receptor. Em concordância com dados já publicados, camundongos deficientes para 0 receptor AhR foram mais susceptíveis à sepse quando comparados aos camundongos WT (Kimura et al., 2009). Ainda, os animais que sobreviveram a sepse foram utilizados para a realização de vários testes.

Primeiramente, o baço dos camundongos foi coletado para avaliar a expressão proteica da IDO e do AhR. Os resultados demonstraram um aumento na expressão da IDO no baço dos camundongos WT submetidos à CLP em relação aos camundongos naive. Por outro lado, não foi observado aumento na expressão proteica da IDO no baço dos camundongos deficientes para o AhR. É interessante ressaltar que, os camundongos deficientes para o AhR foram um pouco mais susceptíveis à sepse quando comparados aos animais WT. Assim, é possível sugerir que, se a ativação do AhR não estivesse envolvida com a expressão proteica da IDO, os animais deficientes para o Ahr deveriam apresentar um aumento na expressão proteica desta enzima com a mesma intensidade daquela observada nos camundongos WT. Este resultado é interessante e suporta a hipótese de que a quinurenina produzida durante a fase aguda da sepse poderia se ligar e ativar o $A h R$, o que seria importante para promover o aumento da expressão proteica da IDO nos camundongos que sobreviveram a sepse. 
É importante ressaltar que, como os camundongos deficientes para o AhR são mais susceptíveis a sepse, foi necessário realizar algumas adaptações no protocolo de CLP com o objetivo de modular a gravidade da sepse. Apesar disso, ainda foi observado aumento na expressão proteica da IDO no baço dos camundongos WT que foram submetidos ao protocolo adaptado. Dessa forma, apesar da redução na quantidade de fezes colocada na cavidade peritoneal dos camundongos, sugerindo uma redução na intensidade dos estímulos próinflamatórios, a gravidade da sepse foi suficiente para promover o aumento da expressão proteica da IDO no baço, reforçando a hipótese de que mediadores produzidos durante a resposta inflamatória induzida pela sepse estão envolvidos na indução da expressão proteica da IDO no pós-sepse.

Um segundo experimento foi realizado para avaliar a capacidade das células do baço de camundongos que sobreviveram à sepse em responder a um segundo estímulo bacteriano. Para isso, células provenientes do baço dos camundongos que sobreviveram a sepse foram coletadas e desafiadas com LPS ou $\mathrm{CpG}$ in vitro. Os resultados demonstraram que, quando apenas PBS foi adicionado a cultura, ocorreu uma maior expressão proteica da IDO nas células provenientes de animais pós-sepse em relação aos animais naive. Este dado confirma os resultados anteriores, demonstrando que, mediadores produzidos durante a sepse são responsáveis por induzir a expressão proteica da enzima.

Como era de se esperar, a ativação das células proveniente de camundongos naive com LPS promoveu aumento na expressão da IDO (Fallarino et al., 2015). Por outro lado, não foi observada diferença na expressão proteica da enzima entre as células recuperadas de camundongos que sobreviveram à sepse tratadas com PBS e LPS. Este resultado permite, pelo 
menos, duas interpretações. Primeiro, é possível que as células atingiram sua capacidade máxima de resposta e não serão capazes de aumentar a expressão proteica da IDO frente a um novo estímulo. A segunda explicação é mais complexa e se relaciona a um fenômeno clinicamente relevante conhecido como endotoxin tolerance ou tolerância induzida pelo LPS. Foi demonstrado que algumas células do sistema imune, previamente ativadas com LPS, perdem a capacidade de montar uma resposta pro-inflamatório eficiente frente a um segundo estímulo com LPS (Biswas et al., 2009). Assim, é possível que as células provenientes de animais que sobreviveram à sepse foram sensibilizadas durante a fase aguda da sepse, o que explicaria a incapacidade destas células em aumentar a expressão proteica da IDO após o segundo desafio com LPS. Os mecanismos associados ao desenvolvimento da tolerância ao LPS são complexos, sendo que, já foi demonstrado que a IDO participa desse processo (Bessede et al., 2014). Porém, apesar dos avanços, ainda são necessários estudos para uma melhor compreensão da possível relação entre a tolerância ao LPS e da imunossupressão induzida pela sepse (Biswas et al., 2009; Bessede et al., 2014).

O resultado obtido no grupo de células desafiadas com $\mathrm{CpG}$, corrobora a hipótese da existência de alguma forma de tolerização durante a sepse. Foi observada uma maior expressão proteica da IDO no grupo de células provenientes de camundongos naive e tratados com GpG em relação ao grupo de células provenientes de animais que sobreviveram a sepse também tratados com CpG. Por fim, independente do estimulo utilizado, não foi observado aumento na expressão proteica da IDO em células provenientes de camundongos deficientes para o receptor $A h R$, o que suporta a hipótese da 
participação deste receptor na expressão da IDO observada em camundongos que sobrevivem à sepse.

As mesmas amostras foram utilizadas para avaliar a expressão proteica do AhR. A análise dos dados demonstrou um aumento da expressão proteica deste receptor apenas nos grupos tratados com LPS. Este resultado está de acordo com dados já publicados, os quais demonstram a capacidade do LPS em induzir a expressão do AhR (Nguyen et al., 2010). Ainda, demonstra que a ativação sofrida pelas células durante a sepse não aboliu a capacidade das células de expressar o AhR após secunda estimulação com LPS.

Os resultados apresentados neste trabalho demonstram uma relação entre a atividade enzimática da IDO e a expressão das Tregs observada em camundongos que sobreviveram a uma sepse grave. Também foi demonstrado uma possível relação entre o receptor AhR e a expressão proteica da IDO nos camundongos que sobrevivem à sepse. Dessa forma, o linfonodo mesentérico de camundongos WT e deficientes para o receptor AhR que sobreviveram à sepse, foi coletado para avaliar a frequência das Tregs. A análise dos resultados demonstrou um aumento na frequência das Tregs no linfonodo dos camundongos WT submetidos à sepse em relação aos camundongos naive. Por outro lado, não ocorreu aumento na frequência das Tregs no linfonodo dos camundongos deficientes para o $\mathrm{AhR}$, corroborando a relação existente entre AhR-IDO na expansão das Tregs que ocorre na imunossupressão induzida pela sepse.

O próximo objetivo deste trabalho foi identificar qual ou quais subtipos celulares estariam expressando a IDO no contexto da imunossupressão induzida pela sepse. Para isso, uma bateria de experimentos foi realizada utilizando a 
técnica de imunofluorescência. Sabe-se que, linfócitos B podem expressar IDO sob determinadas circunstâncias (Munn et al., 2013). Assim, foi utilizado anticorpo contra a proteína B220, classicamente conhecida como marcador desta população celular. A análise das lâminas revelou algumas poucas células com dupla marcação $\left(\mathrm{B}^{2} 20^{+}\right.$e IDO+) apenas nos camundongos naive. Porém, nossos dados demonstram que em camundongos que sobrevivem á sepse, as células que expressam a IDO estão localizadas principalmente fora da região que concentra os linfócitos B no baço. Assim, é possível concluir que a sepse não é um estímulo que ative a expressão da IDO em linfócitos B ou mesmo em outra população celular que expresse este marcador.

Levando em consideração a organização celular no baço, sabe que, as principais populações encontradas fora da região que concentra os linfócitos $B$ são os linfócitos T CD4 e as Células Dendríticas (DC). Assim, primeiramente foram realizados experimento com o objetivo de avaliar se as células expressando a IDO no baço dos camundongos que sobreviveram à sepse eram linfócitos T CD4. Nossos resultados demonstraram claramente que não existe expressão da IDO em células $\mathrm{CD}^{+}$, sugerindo que as células IDO+ não são linfócitos $\mathrm{T} \mathrm{CD}^{+}$. Este dado é interessante e está de acordo com resultados encontrados na literatura, uma vez que, não foram encontrados trabalhos demonstrando a expressão proteica da IDO em linfócitos T.

Por fim, foram realizados experimento para avaliar se células $C D 11 \mathrm{c}^{+}$ estariam expressando IDO em camundongos que sobreviveram à sepse. Os resultados demonstraram que existe co-localização das proteínas IDO e CD11C no baço de camundongos que sobreviveram à sepse, sugerindo que as células responsáveis por expressar a IDO são DC. De fato, nossos resultados estão de 
acordo com dados encontrados na literatura, os quais demonstram a existência de sub-populações de células dendríticas CD11 ${ }^{+}$que passam a expressar a IDO após ativação com ligantes de TLR, como por exemplo, a molécula CpG, um ligante do TLR-9, ou LPS, um ligante de TLR-4 (Mellor et al., 2005; Sharma et al., 2007; Volpi et al., 2013; Fallarino et al., 2015). Ainda, foi demonstrado que

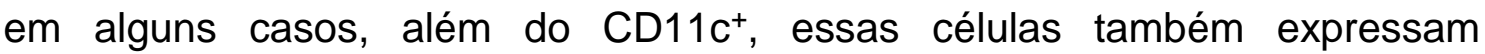
marcadores classicamente encontrados em linfócitos B, como por exemplo, B220 e CD19 (Munn et al., 2004; Mellor et al., 2005; Johnson et al., 2010). É importante ressaltar que, as células $C D 11 c^{+}$que expressando B220 não são linfócitos $B$, uma vez que, camundongos com comprometimento na maturação dos linfócitos B conservaram a população de células $\mathrm{CD} 11 \mathrm{c}^{+}$expressando $\mathrm{o}$ marcador B220 com propriedades supressoras no baço (Johnson et al., 2010).

Nossos resultados sugerem que, pelo menos no contexto da imunossupressão induzida pela sepse, existem células $C D 11 C^{+} I D O^{+}$que não expressam o marcador B220. Dessa forma, foram realizados mais experimento para uma melhor caracterização fenotípica e funcional das células CD11C ${ }^{+}$ capazes de expressar a IDO após à sepse. Para isso, frações contendo as populações CD11c positivas e negativas, originadas do baço de camundongos que sobreviveram à sepse, foram separadas para avaliar a expressão gênica da IDO e do AhR. Em concordância com resultados apresentados anteriormente, foi encontrado um aumento na expressão gênica da IDO na fração de células

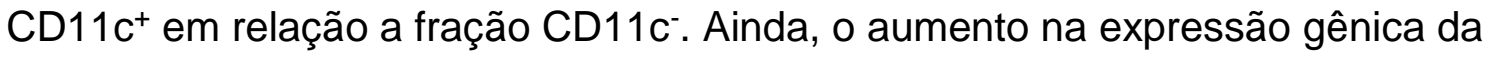
IDO foi dependente do AhR, uma vez que, foi observada redução na expressão gênica da IDO na fração de células positivas, provenientes de camundongos deficientes para este receptor. 
Em linha com os dados apresentados neste trabalho, foi encontrado um aumento da expressão gênica do $A h R$ na fração de células $C D 11 C^{+}$. Este resultado suporta nossa hipótese de que a ativação do AhR é importante para a expressão da IDO em camundongos que sobreviveram à sepse. É importante ressaltar que, resultados anteriores demonstraram um aumento na expressão proteica do AhR no baço de camundongos no terceiro dia após a CLP. Para a realização dos experimentos nos quais as células CD11c foram isoladas do baço, os animais foram eutanasiados no $8^{\circ}$ dia após a sepse, momento em que não foi observado aumento na expressão proteica do AhR nas amostras de baço total. Assim, é possível que, durante a fase aguda da sepse outras células estejam expressando o AhR e por isso foi possível detectar sua expressão proteica no baço total. No $8^{\circ}$ dia após a CLP, é possível que exista uma manutenção da expressão do AhR apenas na população de células $C D 11 c^{+}$, dificultando a detecção proteica do AhR por limitações na sensibilidade da técnica. Assim, seria importante isolara as células $\mathrm{CD}_{11 \mathrm{c}^{+}}$do baço de camundongos que sobreviveram à sepse para avaliação da expressão proteica do AhR.

Já foi demonstrado que células $\mathrm{CD} 11 \mathrm{c}^{+}$que expressam a IDO podem interferir no funcionamento do sistema imune por meio da indução de anergia em linfócitos T, ativação e diferenciação de Tregs, aumento do crescimento tumoral, dentre outros efeitos (Munn et al., 2004; Baban et al., 2005; Sharma et al., 2007; Johnson et al., 2010; Bessede et al., 2014). Nossos resultados demonstraram que células $C D 11 \mathrm{c}^{+}$presentes no baço de camundongos que sobreviveram à sepse passam a expressar a IDO, sendo que, a inibição de sua atividade enzimática promoveu redução na expansão das Tregs e do quadro de 
imunossupressão induzido pela sepse. Assim, nossos achados colocam as células $\mathrm{CD}_{11 \mathrm{C}^{+}}$em uma posição central para o desenvolvimento da imunossupressão, sugerindo que elas poderiam induzir um fenótipo regulador em linfócitos $T$ naive. Assim, o próximo passo deste trabalho foi avaliar a capacidade das células $\mathrm{CD}_{11 \mathrm{C}^{+}}$, provenientes de camundongos que sobreviveram à sepse, induzirem a diferenciação das Tregs a partir de linfócitos T naive

Nossos dados demonstraram que células $\mathrm{CD}_{11 \mathrm{C}^{+}}$provenientes de camundongos que sobreviveram à sepse possuem maior capacidade de induzir a diferenciação de linfócitos T para um perfil regulador, quando comparadas as células $\mathrm{CD}_{11 \mathrm{C}^{+}}$provenientes de animais naive. Sabe-se que, a diferenciação das Tregs é dependente da presença de citocina TGF- $\beta$ (Fu et al., 2004), porém para a realização do experimento de co-cultura apresentado neste trabalho, TGF- $\beta$ exógeno não foi adicionado ao meio de cultura. Assim, seria interessante comparar se existe diferença na produção desta citocina pelas células CD11 $\mathrm{c}^{+}$ oriundas dos camundongos naive ou dos animais que sobreviveram à sepse.

Outro ponto importante está relacionado a produção de quinurenina. Já foi demonstrado que a quinurenina potencializa a diferenciação das Tregs induzida pelo TGF- $\beta$ (Mezrich et al., 2010; Nguyen et al., 2010). Nossos resultados demonstram que as células $\mathrm{CD} 11 \mathrm{c}^{+}$provenientes de camundongos que sobrevivem à sepse estão expressando uma grande quantidade de IDO. Assim, é possível que exista uma maior concentração de quinurenina no meio de cultura que contém as células $\mathrm{CD}_{11 \mathrm{c}^{+}}$proveniente de camundongos que sobreviveram à sepse. Para confirma se a quinurenina produzida das células $\mathrm{CD}_{11 \mathrm{C}^{+}} \mathrm{IDO}^{+}$está envolvida na diferenciação das Tregs observada em 
camundongos que sobrevivem à sepse, seria importante quantificar a produção de quinurenina no sobrenadante das culturas, além de realizar experimento utilizando células $\mathrm{CD} 11 \mathrm{c}^{+}$tratadas com inibidor da IDO ou provenientes de camundongos deficientes para a IDO e linfócitos $T$ naive provenientes de camundongos deficientes para o AhR.

Ainda, outros grupos demonstraram que células $\mathrm{CD} 11 \mathrm{c}^{+}$provenientes do baço de camundongos deficientes para o AhR, apresentam um comprometimento na expressão da IDO e na produção de IL-10. Esse resultado é interessante e suportam nossos dados que indicam que existe uma relação entre AhR e expressão da IDO após a sepse. Além disso, os dados sugerem que a IL-10 poderia participar da indução da IDO nas células $\mathrm{CD} 11 \mathrm{C}^{+}$após ativação do AhR (Nguyen et al., 2010). 


\section{CONCLUSÃO}

Nossos achados sugerem que a ativação do $A h R$ pela quinurenina produzida durante a fase aguda da sepse grave, está associada ao aumento da expressão proteica da IDO em células $\mathrm{CD} 11 \mathrm{c}^{+}$no baço dos camundongos que sobreviventes. Além disso, os resultados demonstram que o aumento da expressão proteica da IDO é um dos mecanismos associados à expansão das Tregs, uma vez que, células $\mathrm{CD}_{11 \mathrm{c}^{+}}$isoladas de camundongos que sobreviveram à sepse foram capazes de induzir uma maior diferenciação de Tregs a partir de linfócitos T CD25- quando comparadas a células CD11 ${ }^{+}$, originadas de camundongos naive. Ainda, o tratamento de camundongos com um inibidor da atividade enzimática da IDO promoveu a redução da expansão das Tregs, no baço de camundongos que sobreviveram à sepse, confirmando a importância de sua atividade enzimática para a expansão das Tregs que ocorre na imunossupressão induzida pela sepse. Por fim, os resultados confirmam a participação da IDO no desenvolvimento da imunossupressão induzida pela sepse, uma vez que, foi identificado uma redução no crescimento tumoral em camundongos desafiados com células do melanoma B16-F10 e tratados com inibidor da IDO em relação animais tratados com salina. 


\section{MECANISMO PROPOSTO}

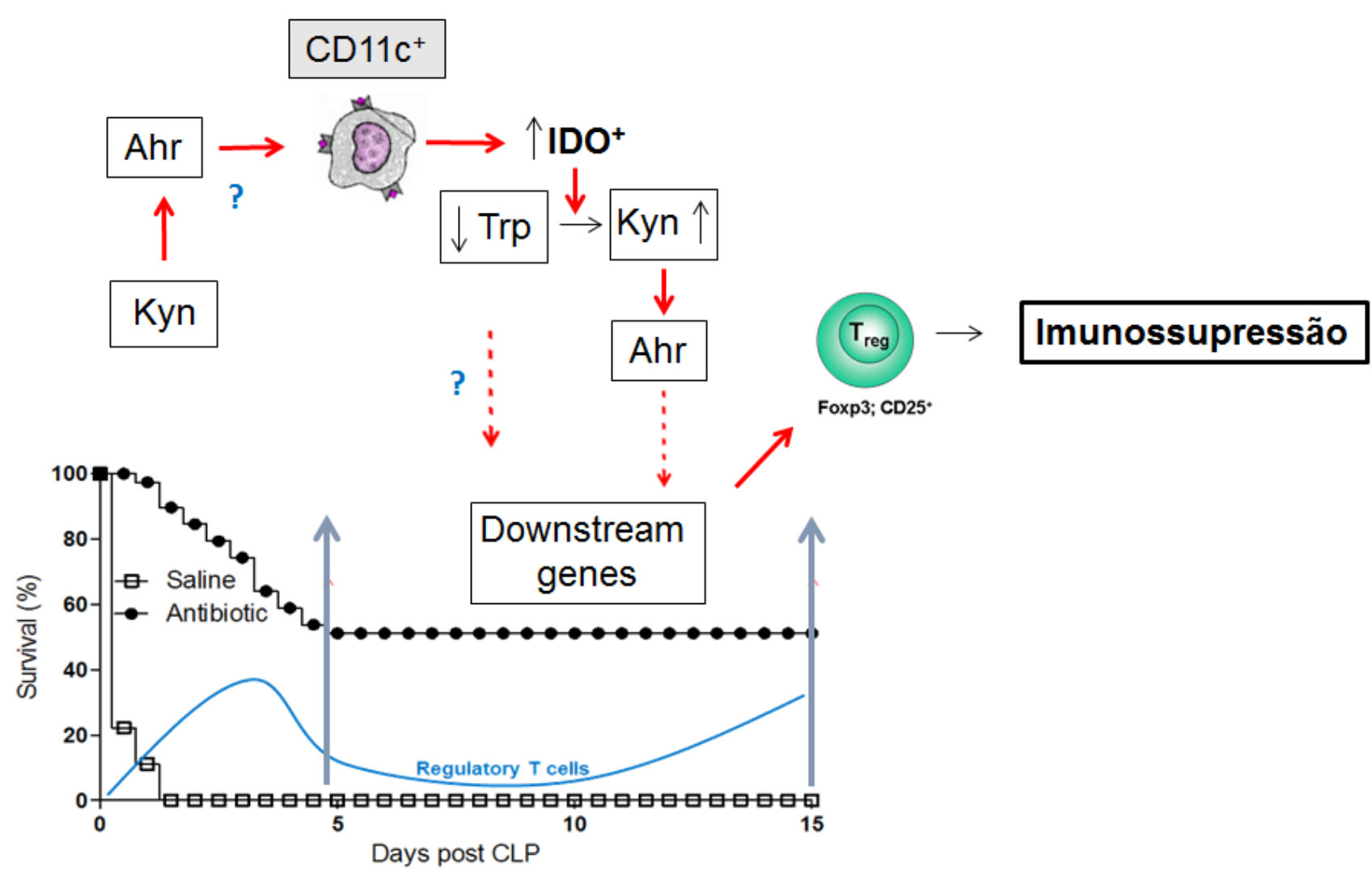

Diagrama 2: Mecanismo proposto após realização deste trabalho

\section{PERSPECTIVAS}

Nas últimas décadas, milhões de dólares foram investidos em pesquisas e estudos clínicos com o objetivo de entender os mecanismos associados ao desenvolvimento da sepse e suas consequências. Porém, apesar dos esforços, ainda não foi identificado um marcador clássico para doença ou mesmo um tratamento eficaz. Ainda, não existem respostas claras capazes de explicar porque em alguns casos a sepse pode promover o desenvolvimento da imunossupressão. Nesse sentido, o objetivo deste trabalho foi entender os mecanismos associados com o desenvolvimento da imunossupressão induzida pela sepse. 
O conjunto de dados apresentados aqui sugerem que a ativação do AhR durante a fase aguda da sepse grave está envolvida com o aumento da expressão tardia da IDO, o que por sua vez, foi importante para 0 desenvolvimento da imunossupressão. Assim, é possível especular que, em um futuro próximo, antagonistas do AhR possam ser utilizados para o tratamento de pacientes diagnosticados com sepse, com o objetivo de reduzir ou mesmo abolir o desenvolvimento do quadro de imunossupressão induzida pela sepse. Também é possível especular que, o grau de expressão do AhR em células $\mathrm{CD} 11 \mathrm{c}^{+}$recuperadas do sangue periférico de pacientes, durante a fase aguda da sepse, possa ser utilizado como prognóstico do desenvolvimento da imunossupressão. Outro possível avanço está relacionado ao uso de inibidores da IDO, que poderão ser utilizados paro o tratamento de pacientes que desenvolveram o quadro de imunossupressão induzida pela sepse.

Em suma, o conhecimento produzido durante o desenvolvimento do presente trabalho, contribuiu para uma melhor compreensão das bases fisiopatológicas da imunossupressão induzida pela sepse. Além disso, os resultados colocam o AhR e a IDO como possíveis alvos farmacológicos que poderão ser utilizados para o desenvolvimento de drogas utilizadas para 0 tratamento da imunossupressão induzida pela sepse. É importante ressaltar que atualmente não existem disponíveis no mercado fármacos para o tratamento eficaz da sepse ou mesmo, de suas consequências. 


\section{REFERÊNCIAS}

Alves-Filho JC, de Freitas A, Russo M, Cunha FQ (2006). Toll-like receptor 4 signaling leads to neutrophil migration impairment in polymicrobial sepsis. Crit Care Med 34(2): 461-470.

Alves-Filho JC, Freitas A, Souto FO, Spiller F, Paula-Neto H, Silva JS, et al. (2009). Regulation of chemokine receptor by Toll-like receptor 2 is critical to neutrophil migration and resistance to polymicrobial sepsis. Proc Natl Acad Sci U S A 106(10): 4018-4023.

Angus DC, Wax RS (2001). Epidemiology of sepsis: an update. Crit Care Med 29(7 Suppl): S109-116.

Baban B, Chandler PR, Johnson BA, 3rd, Huang L, Li M, Sharpe ML, et al. (2011). Physiologic control of IDO competence in splenic dendritic cells. Journal of immunology 187(5): 2329-2335.

Baban B, Hansen AM, Chandler PR, Manlapat A, Bingaman A, Kahler DJ, et al. (2005). A minor population of splenic dendritic cells expressing CD19 mediates IDO-dependent T cell suppression via type I IFN signaling following B7 ligation. Int Immunol 17(7): 909-919.

Benjamim CF, Ferreira SH, Cunha FQ (2000). Role of nitric oxide in the failure of neutrophil migration in sepsis. J Infect Dis 182(1): 214-223.

Bessede A, Gargaro M, Pallotta MT, Matino D, Servillo G, Brunacci C, et al. (2014). Aryl hydrocarbon receptor control of a disease tolerance defence pathway. Nature 511(7508): 184-190.

Biswas SK, Lopez-Collazo E (2009). Endotoxin tolerance: new mechanisms, molecules and clinical significance. Trends Immunol 30(10): 475-487.

Boomer JS, To K, Chang KC, Takasu O, Osborne DF, Walton AH, et al. (2011). Immunosuppression in patients who die of sepsis and multiple organ failure. JAMA 306(23): 2594-2605.

Bronte V, Zanovello P (2005). Regulation of immune responses by L-arginine metabolism. Nature reviews. Immunology 5(8): 641-654.

Cavassani KA, Carson WFt, Moreira AP, Wen H, Schaller MA, Ishii M, et al. (2010). The post sepsis-induced expansion and enhanced function of regulatory T cells create an environment to potentiate tumor growth. Blood 115(22): 44034411.

Cohen J (2002). The immunopathogenesis of sepsis. Nature 420(6917): 885891.

Cohen J, Vincent JL, Adhikari NK, Machado FR, Angus DC, Calandra T, et al. (2015). Sepsis: a roadmap for future research. Lancet Infect Dis 15(5): 581-614. 
Darcy CJ, Davis JS, Woodberry T, McNeil YR, Stephens DP, Yeo TW, et al. (2011). An observational cohort study of the kynurenine to tryptophan ratio in sepsis: association with impaired immune and microvascular function. PLoS One 6(6): e21185.

Dejager L, Pinheiro I, Dejonckheere E, Libert C (2011). Cecal ligation and puncture: the gold standard model for polymicrobial sepsis? Trends in microbiology 19(4): 198-208.

Delano MJ, Scumpia PO, Weinstein JS, Coco D, Nagaraj S, Kelly-Scumpia KM, et al. (2007). MyD88-dependent expansion of an immature GR-1(+)CD11b(+) population induces $T$ cell suppression and Th2 polarization in sepsis. The Journal of experimental medicine 204(6): 1463-1474.

Edinger AL, Thompson CB (2002). Antigen-presenting cells control $\mathrm{T}$ cell proliferation by regulating amino acid availability. Proc Natl Acad Sci U SA 99(3): 1107-1109.

Fallarino F, Grohmann U, You S, McGrath BC, Cavener DR, Vacca C, et al. (2006). The combined effects of tryptophan starvation and tryptophan catabolites down-regulate $T$ cell receptor zeta-chain and induce a regulatory phenotype in naive T cells. J Immunol 176(11): 6752-6761.

Fallarino F, Pallotta MT, Matino D, Gargaro M, Orabona C, Vacca C, et al. (2015). LPS-conditioned dendritic cells confer endotoxin tolerance contingent on tryptophan catabolism. Immunobiology 220(2): 315-321.

Fu S, Zhang N, Yopp AC, Chen D, Mao M, Chen D, et al. (2004). TGF-beta induces Foxp3 + T-regulatory cells from CD4 + CD25 - precursors. American journal of transplantation : official journal of the American Society of Transplantation and the American Society of Transplant Surgeons 4(10): 16141627.

Gabrilovich DI, Nagaraj S (2009). Myeloid-derived suppressor cells as regulators of the immune system. Nature reviews. Immunology 9(3): 162-174.

Grohmann U, Orabona C, Fallarino F, Vacca C, Calcinaro F, Falorni A, et al. (2002). CTLA-4-Ig regulates tryptophan catabolism in vivo. Nat Immuno/ 3(11): 1097-1101.

Hadrup S, Donia M, Thor Straten P (2013). Effector CD4 and CD8 T cells and their role in the tumor microenvironment. Cancer microenvironment : official journal of the International Cancer Microenvironment Society 6(2): 123-133.

Hoshi M, Saito K, Hara A, Taguchi A, Ohtaki H, Tanaka R, et al. (2010). The absence of IDO upregulates type I IFN production, resulting in suppression of viral replication in the retrovirus-infected mouse. J Immunol 185(6): 3305-3312.

Hotchkiss RS, Karl IE (2003). The pathophysiology and treatment of sepsis. $N$ Engl J Med 348(2): 138-150. 
Hotchkiss RS, Monneret G, Payen D (2013a). Immunosuppression in sepsis: a novel understanding of the disorder and a new therapeutic approach. Lancet Infect Dis 13(3): 260-268.

Hotchkiss RS, Monneret G, Payen D (2013b). Sepsis-induced immunosuppression: from cellular dysfunctions to immunotherapy. Nat Rev Immunol 13(12): 862-874.

Hotchkiss RS, Tinsley KW, Swanson PE, Schmieg RE, Jr., Hui JJ, Chang KC, et al. (2001). Sepsis-induced apoptosis causes progressive profound depletion of $B$ and CD4+ T lymphocytes in humans. J Immunol 166(11): 6952-6963.

Huttunen R, Syrjanen J, Aittoniemi J, Oja SS, Raitala A, Laine J, et al. (2010). High activity of indoleamine 2,3 dioxygenase enzyme predicts disease severity and case fatality in bacteremic patients. Shock 33(2): 149-154.

Jia L, Schweikart K, Tomaszewski J, Page JG, Noker PE, Buhrow SA, et al. (2008). Toxicology and pharmacokinetics of 1-methyl-d-tryptophan: absence of toxicity due to saturating absorption. Food and chemical toxicology : an international journal published for the British Industrial Biological Research Association 46(1): 203-211.

Johnson BA, 3rd, Kahler DJ, Baban B, Chandler PR, Kang B, Shimoda M, et al. (2010). B-lymphoid cells with attributes of dendritic cells regulate $T$ cells via indoleamine 2,3-dioxygenase. Proceedings of the National Academy of Sciences of the United States of America 107(23): 10644-10648.

Katz JB, Muller AJ, Prendergast GC (2008). Indoleamine 2,3-dioxygenase in Tcell tolerance and tumoral immune escape. Immunol Rev 222: 206-221.

Kimura A, Naka T, Nakahama T, Chinen I, Masuda K, Nohara K, et al. (2009). Aryl hydrocarbon receptor in combination with Stat1 regulates LPS-induced inflammatory responses. J Exp Med 206(9): 2027-2035.

Liu H, Huang L, Bradley J, Liu K, Bardhan K, Ron D, et al. (2014). GCN2dependent metabolic stress is essential for endotoxemic cytokine induction and pathology. Mol Cell Biol 34(3): 428-438.

Mellor AL, Baban B, Chandler PR, Manlapat A, Kahler DJ, Munn DH (2005). Cutting edge: $\mathrm{CpG}$ oligonucleotides induce splenic CD19+ dendritic cells to acquire potent indoleamine 2,3-dioxygenase-dependent $T$ cell regulatory functions via IFN Type 1 signaling. Journal of immunology 175(9): 5601-5605.

Mezrich JD, Fechner JH, Zhang X, Johnson BP, Burlingham WJ, Bradfield CA (2010). An interaction between kynurenine and the aryl hydrocarbon receptor can generate regulatory T cells. J Immunol 185(6): 3190-3198.

Mota JM, Leite CA, Souza LE, Melo PH, Nascimento DC, de-Deus-Wagatsuma VM, et al. (2016). Post-Sepsis State Induces Tumor-Associated Macrophage 
Accumulation through CXCR4/CXCL12 and Favors Tumor Progression in Mice. Cancer immunology research 4(4): 312-322.

Munn DH, Mellor AL (2013). Indoleamine 2,3 dioxygenase and metabolic control of immune responses. Trends Immuno/ 34(3): 137-143.

Munn DH, Sharma MD, Hou D, Baban B, Lee JR, Antonia SJ, et al. (2004). Expression of indoleamine 2,3-dioxygenase by plasmacytoid dendritic cells in tumor-draining lymph nodes. The Journal of clinical investigation 114(2): 280290.

Murdoch C, Muthana M, Coffelt SB, Lewis CE (2008). The role of myeloid cells in the promotion of tumour angiogenesis. Nat Rev Cancer 8(8): 618-631.

Nascimento DC, Alves-Filho JC, Sonego F, Fukada SY, Pereira MS, Benjamim $C$, et al. (2010). Role of regulatory T cells in long-term immune dysfunction associated with severe sepsis. Crit Care Med 38(8): 1718-1725.

Nguyen NT, Kimura A, Nakahama T, Chinen I, Masuda K, Nohara K, et al. (2010). Aryl hydrocarbon receptor negatively regulates dendritic cell immunogenicity via a kynurenine-dependent mechanism. Proc Natl Acad Sci U S A 107(46): 1996119966.

Okoye IS, Coomes SM, Pelly VS, Czieso S, Papayannopoulos V, Tolmachova T, et al. (2014). MicroRNA-containing T-regulatory-cell-derived exosomes suppress pathogenic T helper 1 cells. Immunity 41(1): 89-103.

Overwijk WW, Restifo NP (2001). B16 as a Mouse Model for Human Melanoma. In. Current Protocols in Immunology, edn: John Wiley \& Sons, Inc. p^pp.

Pallotta MT, Orabona C, Volpi C, Vacca C, Belladonna ML, Bianchi R, et al. (2011). Indoleamine 2,3-dioxygenase is a signaling protein in long-term tolerance by dendritic cells. Nat Immunol 12(9): 870-878.

Ploder M, Spittler A, Kurz K, Neurauter G, Pelinka LE, Roth E, et al. (2010). Accelerated tryptophan degradation predicts poor survival in trauma and sepsis patients. International journal of tryptophan research : IJTR 3: 61-67.

Powell DJ, Jr., Rosenberg SA (2004). Phenotypic and functional maturation of tumor antigen-reactive CD8+ T lymphocytes in patients undergoing multiple course peptide vaccination. $J$ Immunother 27(1): 36-47.

Powell JD, Pollizzi KN, Heikamp EB, Horton MR (2012). Regulation of immune responses by mTOR. Annu Rev Immunol 30: 39-68.

Puccetti P (2007). On watching the watchers: IDO and type I/II IFN. Eur J Immunol 37(4): 876-879. 
Quartin AA, Schein RM, Kett DH, Peduzzi PN (1997). Magnitude and duration of the effect of sepsis on survival. Department of Veterans Affairs Systemic Sepsis Cooperative Studies Group. JAMA 277(13): 1058-1063.

Quintana FJ, Sherr DH (2013). Aryl hydrocarbon receptor control of adaptive immunity. Pharmacol Rev 65(4): 1148-1161.

Riedemann NC, Guo RF, Ward PA (2003). Novel strategies for the treatment of sepsis. Nat Med 9(5): 517-524.

Rodriguez PC, Zea AH, Culotta KS, Zabaleta J, Ochoa JB, Ochoa AC (2002). Regulation of $\mathrm{T}$ cell receptor CD3zeta chain expression by L-arginine. The Journal of biological chemistry 277(24): 21123-21129.

Sharma MD, Baban B, Chandler P, Hou DY, Singh N, Yagita H, et al. (2007). Plasmacytoid dendritic cells from mouse tumor-draining lymph nodes directly activate mature Tregs via indoleamine 2,3-dioxygenase. J Clin Invest 117(9): 2570-2582.

Shevach EM (2009). Mechanisms of foxp3+ $T$ regulatory cell-mediated suppression. Immunity 30(5): 636-645.

Shimizu T, Nomiyama S, Hirata F, Hayaishi O (1978). Indoleamine 2,3dioxygenase. Purification and some properties. J Biol Chem 253(13): 4700-4706.

Silva E, Pedro Mde A, Sogayar AC, Mohovic T, Silva CL, Janiszewski M, et al. (2004). Brazilian Sepsis Epidemiological Study (BASES study). Crit Care 8(4): R251-260.

Singer M, Deutschman CS, Seymour CW, Shankar-Hari M, Annane D, Bauer M, et al. (2016). The Third International Consensus Definitions for Sepsis and Septic Shock (Sepsis-3). JAMA 315(8): 801-810.

Sinha P, Clements VK, Bunt SK, Albelda SM, Ostrand-Rosenberg S (2007). Cross-talk between myeloid-derived suppressor cells and macrophages subverts tumor immunity toward a type 2 response. Journal of immunology 179(2): 977983.

Sonego F, Castanheira FV, Ferreira RG, Kanashiro A, Leite CA, Nascimento DC, et al. (2016). Paradoxical Roles of the Neutrophil in Sepsis: Protective and Deleterious. Frontiers in immunology 7: 155.

Souto FO, Alves-Filho JC, Turato WM, Auxiliadora-Martins M, Basile-Filho A, Cunha FQ (2011). Essential role of CCR2 in neutrophil tissue infiltration and multiple organ dysfunction in sepsis. Am J Respir Crit Care Med 183(2): 234-242.

Stone TW, Darlington LG (2002). Endogenous kynurenines as targets for drug discovery and development. Nat Rev Drug Discov 1(8): 609-620. 
Takeda K, Kaisho T, Akira S (2003). Toll-like receptors. Annu Rev Immunol 21: 335-376.

Takikawa $O$ (2005). Biochemical and medical aspects of the indoleamine 2,3dioxygenase-initiated L-tryptophan metabolism. Biochem Biophys Res Commun 338(1): 12-19.

Takikawa O, Yoshida R, Kido R, Hayaishi O (1986). Tryptophan degradation in mice initiated by indoleamine 2,3-dioxygenase. J Biol Chem 261 (8): 3648-3653.

Tattevin P, Monnier D, Tribut O, Dulong J, Bescher N, Mourcin F, et al. (2010). Enhanced indoleamine 2,3-dioxygenase activity in patients with severe sepsis and septic shock. J Infect Dis 201(6): 956-966.

Taylor MW, Feng GS (1991). Relationship between interferon-gamma, indoleamine 2,3-dioxygenase, and tryptophan catabolism. FASEB J 5(11): 25162522.

Trevelin SC, Alves-Filho JC, Sonego F, Turato W, Nascimento DC, Souto FO, et al. (2012). Toll-like receptor 9 activation in neutrophils impairs chemotaxis and reduces sepsis outcome. Crit Care Med 40(9): 2631-2637.

Vecsei L, Szalardy L, Fulop F, Toldi J (2013). Kynurenines in the CNS: recent advances and new questions. Nat Rev Drug Discov 12(1): 64-82.

Victor VM, Rocha M, De la Fuente M (2004). Immune cells: free radicals and antioxidants in sepsis. Int Immunopharmacol 4(3): 327-347.

Volpi C, Fallarino F, Pallotta MT, Bianchi R, Vacca C, Belladonna ML, et al. (2013). High doses of CpG oligodeoxynucleotides stimulate a tolerogenic TLR9TRIF pathway. Nature communications 4: 1852.

Wagner E, Frank MM (2010). Therapeutic potential of complement modulation. Nat Rev Drug Discov 9(1): 43-56.

Wang TS, Deng JC (2008). Molecular and cellular aspects of sepsis-induced immunosuppression. J Mol Med (Berl) 86(5): 495-506.

Weycker D, Akhras KS, Edelsberg J, Angus DC, Oster G (2003). Long-term mortality and medical care charges in patients with severe sepsis. Crit Care Med 31(9): 2316-2323.

Wirthgen E, Hoeflich A (2015). Endotoxin-Induced Tryptophan Degradation along the Kynurenine Pathway: The Role of Indolamine 2,3-Dioxygenase and Aryl Hydrocarbon Receptor-Mediated Immunosuppressive Effects in Endotoxin Tolerance and Cancer and Its Implications for Immunoparalysis. Journal of amino acids 2015: 973548. 
Wirthgen E, Tuchscherer M, Otten W, Domanska G, Wollenhaupt K, Tuchscherer A, et al. (2014). Activation of indoleamine 2,3-dioxygenase by LPS in a porcine model. Innate immunity 20(1): 30-39.

Wisnoski N, Chung CS, Chen Y, Huang X, Ayala A (2007). The contribution of CD4+ CD25+ T-regulatory-cells to immune suppression in sepsis. Shock 27(3): 251-257.

Youn JI, Nagaraj S, Collazo M, Gabrilovich DI (2008). Subsets of myeloid-derived suppressor cells in tumor-bearing mice. Journal of immunology 181(8): 57915802. 
10. ANEXOS 


\section{OPEN ACCESS}

Edited by:

Mariagrazia Uguccioni, Institute for Research in Biomedicine, Switzerland

Reviewed by: Daniele Souza,

Universidade Federal de

Minas Gerais, Brazil

Marco A. Cassatella,

University of Verona, Italy

${ }^{*}$ Correspondence:

Fernando Queiróz Cunha

fdqcunha@fmrp.usp.br

tPresent address:

Fabiane Sônego,

Imagopole, Institut Pasteur,

Paris, France

Specialty section:

This article was submitted

to Inflammation,

a section of the journal

Frontiers in Immunology

Received: 19 February 2016

Accepted: 11 April 2016

Published: 26 April 2016

Citation:

Sônego F, Castanheira FVS,

Ferreira RG, Kanashiro A,

Leite CAVG, Nascimento DC, Colón DF, Borges VF, Alves-Filho JC and Cunha FQ (2016) Paradoxical Roles of the Neutrophil in Sepsis:

Protective and Deleterious.

Front. Immunol. 7:155. doi: 10.3389/fimmu.2016.00155

\section{Paradoxical Roles of the Neutrophil in Sepsis: Protective and Deleterious}

\author{
Fabiane Sônego ${ }^{1 \dagger}$, Fernanda Vargas e Silva Castanheira ${ }^{1}$, Raphael Gomes Ferreira' ${ }^{1}$, \\ Alexandre Kanashiro ${ }^{1}$, Caio Abner Vitorino Gonçalves Leite ${ }^{1}$, Daniele Carvalho Nascimento ${ }^{1}$, \\ David Fernando Colón ${ }^{2}$, Vanessa de Fátima Borges ${ }^{1}$, José Carlos Alves-Filho ${ }^{1}$ and \\ Fernando Queiróz Cunha ${ }^{1 \star}$
}

\begin{abstract}
'Departamento de Farmacologia, Faculdade de Medicina de Ribeirão Preto, Universidade de São Paulo, Ribeirão Preto, Brazil, ${ }^{2}$ Departamento de Bioquímica e Imunologia, Faculdade de Medicina de Ribeirão Preto, Universidade de São Paulo, Ribeirão Preto, Brazil
\end{abstract}

Sepsis, an overwhelming inflammatory response syndrome secondary to infection, is one of the costliest and deadliest medical conditions worldwide. Neutrophils are classically considered to be essential players in the host defense against invading pathogens. However, several investigations have shown that impairment of neutrophil migration to the site of infection, also referred to as neutrophil paralysis, occurs during severe sepsis, resulting in an inability of the host to contain and eliminate the infection. On the other hand, the neutrophil antibacterial arsenal contributes to tissue damage and the development of organ dysfunction during sepsis. In this review, we provide an overview of the main events in which neutrophils play a beneficial or deleterious role in the outcome of sepsis.

Keywords: sepsis, neutrophil migration, organ dysfunction, toll-like receptors, chemotactic receptors

\section{INTRODUCTION}

Sepsis represents a challenging health care and economical problem worldwide with lingering aftereffects (1). The incidence of sepsis has increased over the last decades (2). In terms of diagnosis, sepsis is a systemic response to infection, with increasing severity recognized as severe sepsis or septic shock. Severe sepsis is defined as sepsis in the presence of organ dysfunction and septic shock as the presence of hypotension unresponsive to vasoconstrictors (3). Intensive preclinical studies performed in the last decades have contributed greatly to the understanding the pathophysiology of sepsis, though it is not yet fully understood. Neutrophils are important players in the outcome of sepsis. Therefore, we will review the involvement of neutrophils in the pathophysiology of sepsis in this work.

\section{CONTROL OF INFECTIONS BY NEUTROPHILS}

Neutrophils are leukocytes with multi-lobed nuclei that form in the bone marrow and are released in their mature form to the blood. Neutrophils have a short life span and do not show proliferative properties $(4,5)$.

Classically recognized as phagocytic cells, neutrophils are associated with the innate immune response. These cells are recruited to the site of the infection in response to chemotactic mediators, where they play antimicrobial roles $(5,6)$. 
The presence of neutrophils at the site of infection has been demonstrated to be essential for controlling the bacterial and fungal burden and avoiding the systemic spread of the infection (7). Indeed, depletion of neutrophils in mice infected with Staphylococcus aureus markedly reduced the clearance of the bacteria and also survival (8). Similarly, depletion of neutrophils in mice infected with Candida albicans induced dissemination of the fungus and led to a higher mortality rate. Likewise, neutropenic patients are more susceptible to bacterial and fungal infections (9-11).

Neutrophils induce killing of pathogens via phagocytosis, degranulation, or even the release of intracellular components such as DNA, histones, and lytic proteins, which form neutrophil extracellular traps (NETs) $(12,13)$. Nitric oxide (NO), a mediator produced by the enzyme inducible nitric oxide synthase (iNOS), is one crucial mediator of the microbicidal activity of neutrophils. Deletion of $i N O S$ induces a high mortality rate due to impaired control of the infection, despite the presence of neutrophils in the locale of the infection (14).

Additionally, neutrophils are equipped with receptors that recognize pathogen-associated molecular patterns or damageassociated molecular patterns, initiating signaling cascades and leading to the production of inflammatory mediators to establish an appropriate response against the pathogen. This results in amplification of the inflammatory process, including emigration of the new waves of neutrophils to the site of infection (15).

Chemokines are a family of small cytokines that are divided into small subfamilies based on variations of a conserved cysteine motif and play an important role in neutrophil recruitment (16). Most chemokines belong to the CC and CXC chemokine subfamilies (17), which exhibit two juxtaposed cysteine residues or one amino acid between the first two cysteine residues, respectively (18). Under physiological conditions, lymphocytes, monocytes, and macrophages express CC receptors (CCR) and respond to $\mathrm{CC}$ chemokines, whereas neutrophils express $\mathrm{CXC}$ receptors (CXCR)1 (IL-8R in humans) and CXCR2 and respond to CXC chemokines (19).

\section{NEUTROPHIL MIGRATION IS IMPAIRED DURING SEVERE SEPSIS}

As mentioned above, the control of an infection depends on the efficient migration of neutrophils to the site of infection as well as appropriate microbicidal activity (20). Our group and others have demonstrated that mice subjected to severe sepsis show inadequate migration of neutrophils to the site of infection, despite the high levels of chemokines at the site. The insufficient number of neutrophils recruited to the site of infection does not control the infection locally, contributing to the systemic spread of the pathogen. As consequence, a marked systemic inflammatory response is established, which is associated with high mortality rates (21).

Among the mechanisms leading to the failure of neutrophil migration, it has been shown that CXCR2 is internalized in circulating neutrophils from mice or patients with severe sepsis (22-24). Accordingly, neutrophils isolated from septic patients show reduced migration toward chemotactic mediators ex vivo, which is associated with patient survival: survivors show higher neutrophil migration compared with non-survivors (25).

In recent years, several studies have described the mechanisms underlying CXCR2 internalization in circulating neutrophils during sepsis, resulting in failure of migration to the infectious focus (Figure 1) (24, 26-29). It has been reported that chemokine receptors belong to the $\mathrm{G}$ protein-coupled receptors (GPCRs), and their expression is precisely regulated (30). Prolonged or repeated exposure to agonists induces desensitization and

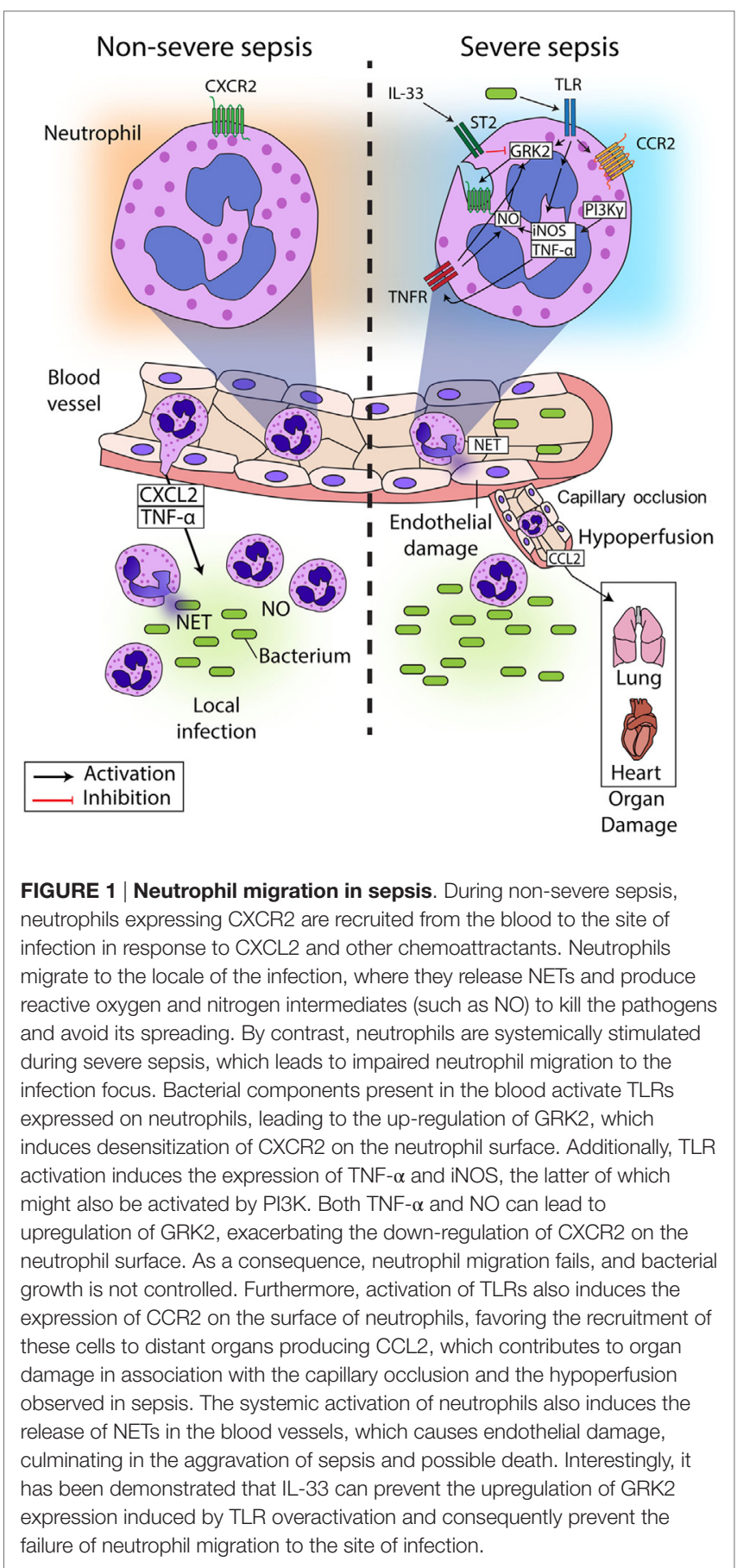


internalization of GPCRs in a process dependent on the activation of GPCR kinases (GRKs) (31). GRKs phosphorylate the intracellular domains of the activated GPCR, leading to the recruitment of arrestin, which decouples the $G$ protein from the receptor and trigger its internalization (32). Our group and others have demonstrated that ligands of Toll-like receptor (TLR)2, TLR4, and TLR9 (lipoteichoic acid (LTA), lipopolysaccharide (LPS), and CpG-oligodeoxynucleotide, respectively) induce GRK2 upregulation in circulating neutrophils, which in turn, leads to CXCR2 internalization $(26,29,33-35)$. Indeed, pretreatment of neutrophils with a GRK2 inhibitor prevented the effect of TLR4 and TLR9 activation on CXCR2 internalization $(33,34)$. Corroborating these data, tlr2-, 4-, and 9-deficient mice show an increase in CXCR2 expression on circulating neutrophils, compared with WT mice subjected to severe sepsis $(26,34,36)$. Additionally, IL-33, a member of the IL-1 family that binds to the heterodimeric receptor complex ST2, has been shown to prevent the up-regulation of GRK2 mediated by TLR signaling. IL-33 treatment improved the recruitment of neutrophils to the site of infection in mice and prevented LPS-induced chemotaxis reduction in human neutrophils $(33,37)$.

It is noteworthy that in contrast to the harmful TLR overactivation in circulating neutrophils, adequate activation of TLRs in migrated neutrophils is crucial for establishing the local immune response. Indeed, tlr4-mutant mice fail to control a low-dose infection with the Gram-negative bacterium Salmonella typhimurium (36). Moreover, myd88-deficient mice are highly susceptible to polymicrobial sepsis because the lack of the adaptor protein involved in most of TLR signaling prevents the establishment of the local inflammatory response. In contrast to the TLRs, the pattern recognition receptors Nod-like receptors 1 and 2 are not involved in neutrophil migration to the site of infection or in the establishment of the inflammatory response locale in mice subjected to CLP-induced polymicrobial sepsis (38).

Further investigation of how TLRs modulate the expression of CXCR2 on the neutrophil surface suggested the involvement of tumor necrosis factor (TNF)- $\alpha$ and NO. Neutrophils isolated from tnf receptor-deficient mice activated with LPS do not show internalization of CXCR2 or impaired chemotaxis to CXCL2. Additionally, neutrophils treated with TNF- $\alpha$ exhibit reduced chemotaxis toward CXCL2 (27). Moreover, NO confers a similar effect in LPS- or IL-8-stimulated neutrophils. Indeed, inhibition of iNOS reduces the effect of the LPS or IL- 8 on the internalization of CXCR2 and the chemotactic activity of CXCR2 agonists $(24,29)$. NO triggers the activation of soluble guanylate cyclases (GCs) as well as cyclic-GMP formation and protein kinase $\mathrm{G}$ (PKG) phosphorylation (39). As expected, inhibition of sGC or PKG had the same effect as iNOS inhibition after LPS stimulation of neutrophils. Interestingly, inhibition of sGC and PKG during experimental sepsis protected mice from death, and this effect was associated with reduced expression of GRK2 in neutrophils, increased expression of CXCR2 and, consequently, increased neutrophil migration to the infectious focus compared with non-treated animals (29).

Based on these observations, we could suggest that TNF- $\alpha$ production and/or release in neutrophils is important to the effect of TLRs on the CXCR2 expression on these cells. In addition, both TLR- and TNF-dependent pathways upregulate inducible NO synthase, which could in turn induce GRK2 expression, leading to reduced CXCR2 expression on the neutrophil surface (40).

In addition to TNF- $\alpha$ and iNOS, it has been demonstrated that phosphoinositide-3 kinase gamma (PI3K $\gamma$ ) plays an important role in this process (28). Interestingly, PI3K may be involved in the dimerization of iNOS, an essential process for the activity of this enzyme (41). GRK2 upregulation and CXCR2 internalization were shown to be inhibited in $\mathrm{PI} 3 \mathrm{~K}^{-/-}$neutrophils incubated

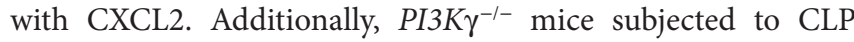
present reduced GRK2 expression and increased CXCR2 expression on the neutrophil surface, resulting in higher survival rates (28). Altogether, these data provide substantial evidence of the links between all pathways discussed above and highlight new potential targets for sepsis treatment.

In contrast to the deleterious role of the pathways described above, there are also mediators that protect the organism against sepsis. One example is hydrogen sulfide $\left(\mathrm{H}_{2} \mathrm{~S}\right)$, a gas produced by the organism that is synthesized from L-cysteine, mainly via the cystathionine b-synthase and cystathionine g-lyase (CSE) enzymes (42). It has been demonstrated that CSE activity is increased during sepsis, and inhibition of CSE reduces CLP-induced leukocyte-endothelial interactions in mesenteric venules, decreases neutrophil migration to the site of infectious, and consequently decreases the survival rate of animals subjected to non-severe sepsis (43). In contrast, treatment of mice subjected to severe sepsis with an $\mathrm{H}_{2} \mathrm{~S}$ donor has the opposite effect, resulting in increased CXCR2 expression on circulating neutrophils, increased neutrophil migration to the infection focus, and improvement survival (43). Thus, $\mathrm{H}_{2} \mathrm{~S}$ donors could be considered for use in sepsis treatment.

Additionally, neutrophil migration events during sepsis have been demonstrated to be regulated by several other mediators, such as lectin-like oxidized low-density lipoprotein receptor (LOX)-1, peroxynitrite, and the acute-phase alpha-1 acid protein, which contribute to the failure of neutrophil migration to the site of infection (44-46). Conversely, the cytokine IL-17 has been shown to be crucial for recruiting neutrophils to the site of infection during sepsis (47). In contrast, the role of the peroxisome proliferator-activated receptor in neutrophil migration during sepsis remains to be confirmed, as both protective and deleterious role have been described $(48,49)$. The effects of these mediators on the neutrophil migration have been reviewed elsewhere $(20,50,51)$ and will not be further addressed here.

\section{NEUTROPHIL-INDUCED ORGAN DAMAGE}

In addition to the host-protective role of neutrophils in sepsis via the killing of microorganisms, these cells have been described as exhibiting deleterious functions (6). During sepsis, it has been shown that the systemic inflammatory response leads to the activation of circulating neutrophils sequestered in capillary beds, occluding the lumen, and inducing tissue ischemia. Additionally, neutrophils can migrate to vital organs and release lytic factors and pro-inflammatory cytokines, contributing to organ damage and subsequent multiple organ dysfunction $(52,53)$. Chemokines 
and chemokine receptors are also involved in the process of neutrophil infiltration into vital organs during sepsis. In contrast to the observation that CXCR2 is internalized in circulating neutrophils during severe sepsis (24), this receptor has been implicated in neutrophil infiltration into the lungs, due to the release of CXC chemokines in this organ during sepsis $(54,55)$. This apparent contradiction could be explained by the differences in the severity of sepsis induced in each study.

Furthermore, our group and others have demonstrated that CCR receptors, which are not expressed on neutrophils under physiological conditions, are induced in this cell type in various inflammatory processes (56-60). It was demonstrated that CCR2 is induced on the neutrophil surface in mice and patients with sepsis in a TLR2- or TLR4-dependent manner. Importantly, CCR2 does not mediate neutrophil recruitment to the site of infection, but it does mediate neutrophil infiltration in vital organs, such as the lungs, kidneys, and heart. Blockage of CCR2 decreases organ damage and death in animals subjected to severe CLP. Moreover, CCR2 expression is positively correlated with the severity of the disease, as measured using the Sepsis-related Organ Failure Assessment (SOFA) score. Accordingly, human neutrophils isolated from non-surviving septic patients express more CCR2 than neutrophils from surviving patients (59).

Another important feature of neutrophils is the formation of NETs, a network of chromatin fibers associated with granules of antimicrobial peptides and enzymes such as myeloperoxidase, elastase, and cathepsin G, which immobilize and kill invading microorganisms to prevent their spreading (61). The role of NETs in the control of bacterial spreading in sepsis is controversial. Similar bacterial loads were observed in animals lacking an important enzyme (peptidylarginine deiminase 4) for NET formation and in animals treated with rhDNAse compared with control mice $(62,63)$. However, our group and others $(64,65)$ have observed an important role of NETs in the control of bacterial spreading during sepsis.

In addition to the role of the NETs in bacterial control during infection, excessive formation of NETs has been observed in many pathological conditions, which is related to organ damage (66). Activated endothelial cells induce the formation of NETs by neutrophils in vitro $(67,68)$. Moreover, in an LPS-induced endotoxic shock model, NETs have adhered and activated the vascular endothelium (69). Additionally, the interaction between neutrophils and activated platelets during sepsis induces NET formation, which contributes to endothelial cell damage and organ injuries (70). Moreover, it has been reported that histones and myeloperoxidase could be responsible for NET-induced endothelial dysfunction, and histones can also interact with TLR2 and TLR4 to induce cytokine production via MyD88 signaling, contributing to the systemic inflammatory response observed in sepsis $(68,71-74)$.

Surprisingly, the survival rate was not found to differ between rhDNAse-treated and non-treated mice after CLP (65). Further investigations revealed that this lack of a difference was due to the deleterious role of NETs in organ damage, as discussed above. Thus, when antibiotic therapy and rhDNAse treatment or inhibition of the enzyme peptidylarginine deiminase 4 were used in combination to control a bacterial infection, a marked increase in the survival rate of the animals was observed, which was associated with decreased organ damage $(63,65)$. In addition, pretreatment with rh-DNAse in animals challenged with LPS decreased the organ damage and increased the survival rate during endotoxemia (65).

The observations from mouse models confirm the human ones. Notably, autopsy examinations of tissues from septic patients with multiple organ dysfunction syndrome indicate the presence of neutrophils sequestered into the kidneys and lungs (75). Furthermore, severity of acute respiratory distress syndrome in septic patients is proportional to the intensity of the inflammatory infiltrate and proteolytic enzymes in the bronchoalveolar lavage (76).

During sepsis, organ failure is associated with hypoperfusion and tissue hypoxia, both of which are attributed to hypotension and occlusion of neutrophils in the microcirculation $(77,78)$. The cytokines secreted by neutrophils attached to a vessel wall can also cause endothelial dysfunction, establishing a thrombogenic profile and favoring intravascular coagulation (79). Additionally, neutrophil products can also induce increased NO production by various cell types, which can contribute to lowering blood pressure (80) and favors the generation of peroxynitrite, a potent oxidant agent. In the heart, peroxynitrite can cause changes in the structure and function of proteins that may be related to sepsis-associated myocardial failure (81). Thus, the adhesion of neutrophil to the endothelium and their sequestration to the heart may have multiple deleterious cardiovascular effects.

\section{CONCLUSION AND PERSPECTIVES}

It is clear that sepsis continues to represent a challenge for basic and clinical researchers. Despite the massive amount of basic and clinical results related to this syndrome that has been published in the literature in the last several decades, there has been an absence of effective new treatments. The high mortality associated with sepsis together with its increased incidence, points to the importance of re-evaluation of the literature as well as the new translational studies addressing the disease. Together, these approaches will help to identify new effective targets for the development of new therapies. In this context, the present review described the dual roles of neutrophils in the evolution of sepsis. These cells are key players in the innate immune response in the early phase of sepsis and their recruitment to sites of infection is crucial for controlling microorganism growth. Aggravation of sepsis is associated with failure of neutrophil migration to the site of infection. The molecular mechanism involved in this phenomenon was described, and several potential targets for the development of new therapies were identified. By contrast, neutrophils can be harmful and induce secondary organ damage during infection. Neutrophil recruitment to organs far from the site of infection is mediated by the expression of CCR2 under septic conditions. The mechanism involved in the harmful effect of the neutrophils was also described in this review, noting potential targets for the development of new therapies. In this context, new therapies targeting the harmful activity of neutrophils, such as blocking 
NET formation or CCR2 activity, might be more helpful than targeting the general inflammatory response.

\section{AUTHOR CONTRIBUTIONS}

FS, FC, AK, CL, RF, DN, DC, VB, JA-F, and FC wrote and approved the text. CL draws the figure.

\section{REFERENCES}

1. Horeczko T, Green JP, PanacekEA. Epidemiology of the Systemic Inflammatory Response Syndrome (SIRS) in the emergency department. West J Emerg Med (2014) 15:329-36. doi:10.5811/westjem.2013.9.18064

2. Kumar G, Kumar N, Taneja A, Kaleekal T, Tarima S, McGinley E, et al. Nationwide trends of severe sepsis in the 21st century (2000-2007). Chest (2011) 140:1223-31. doi:10.1378/chest.11-0352

3. Bone RC, Sibbald WJ, Sprung CL. The ACCP-SCCM consensus conference on sepsis and organ failure. Chest (1992) 101:1481-3. doi:10.1378/ chest.101.6.1481

4. Galli SJ, Borregaard N, Wynn TA. Phenotypic and functional plasticity of cells of innate immunity: macrophages, mast cells and neutrophils. Nat Immunol (2011) 12:1035-44. doi:10.1038/ni.2109

5. Kolaczkowska E, Kubes P. Neutrophil recruitment and function in health and inflammation. Nat Rev Immunol (2013) 13:159-75. doi:10.1038/nri3399

6. Mantovani A, Cassatella MA, Costantini C, Jaillon S. Neutrophils in the activation and regulation of innate and adaptive immunity. Nat Rev Immunol (2011) 11:519-31. doi:10.1038/nri3024

7. Ermert D, Zychlinsky A, Urban C. Fungal and bacterial killing by neutrophils. Methods Mol Biol (2009) 470:293-312. doi:10.1007/978-1-59745-204-5_21

8. Robertson CM, Perrone EE, McConnell KW, Dunne WM, Boody B, Brahmbhatt $\mathrm{T}$, et al. Neutrophil depletion causes a fatal defect in murine pulmonary Staphylococcus aureus clearance. J Surg Res (2008) 150:278-85. doi:10.1016/j.jss.2008.02.009

9. Bouma G, Ancliff PJ, Thrasher AJ, Burns SO. Recent advances in the understanding of genetic defects of neutrophil number and function. Br J Haematol (2010) 151:312-26. doi:10.1111/j.1365-2141.2010.08361.x

10. Brown GD, Denning DW, Gow NA, Levitz SM, Netea MG, White TC. Hidden killers: human fungal infections. Sci Transl Med (2012) 4:165rv113. doi:10.1126/scitranslmed.3004404

11. Swamydas M, Gao JL, Break TJ, Johnson MD, Jaeger M, Rodriguez CA, et al. CXCR1-mediated neutrophil degranulation and fungal killing promote Candida clearance and host survival. Sci Transl Med (2016) 8:322ra310. doi:10.1126/scitranslmed.aac7718

12. Nathan C. Neutrophils and immunity: challenges and opportunities. Nat Rev Immunol (2006) 6:173-82. doi:10.1038/nri1785

13. Bardoel BW, Kenny EF, Sollberger G, Zychlinsky A. The balancing act of neutrophils. Cell Host Microbe (2014) 15:526-36. doi:10.1016/j.chom.2014.04.011

14. Benjamim CF, Silva JS, Fortes ZB, Oliveira MA, Ferreira SH, Cunha FQ. Inhibition of leukocyte rolling by nitric oxide during sepsis leads to reduced migration of active microbicidal neutrophils. Infect Immun (2002) 70:3602-10. doi:10.1128/IAI.70.7.3602-3610.2002

15. Bianchi ME. DAMPs, PAMPs and alarmins: all we need to know about danger. J Leukoc Biol (2007) 81:1-5. doi:10.1189/jlb.0306164

16. Luster $\mathrm{AD}$. Chemokines - chemotactic cytokines that mediate inflammation. N Engl J Med (1998) 338:436-45. doi:10.1056/nejm199802123380706

17. Graham GJ. D6 and the atypical chemokine receptor family: novel regulators of immune and inflammatory processes. Eur J Immunol (2009) 39:342-51. doi:10.1002/eji.200838858

18. Rollins BJ. Chemokines. Blood (1997) 90:909-28.

19. Mantovani A, Bonecchi R, Locati M. Tuning inflammation and immunity by chemokine sequestration: decoys and more. Nat Rev Immunol (2006) 6:907-18. doi:10.1038/nri1964

20. Sonego F, Alves-Filho JC, Cunha FQ. Targeting neutrophils in sepsis. Expert Rev Clin Immunol (2014) 10:1019-28. doi:10.1586/1744666X.2014.922876

\section{FUNDING}

This work was supported by São Paulo Research Foundation (FAPESP), grant \#2008/11593-4 and \#2011/19670-0, CNPq (Conselho Nacional de Desenvolvimento Científico e Tecnológico) and European Community's Seventh Framework Programme [FP7-2007-2013] under grant agreement $\mathrm{n}^{\circ}$ HEALTH-F4-2011-281608 (TIMER).

21. Alves-Filho JC, de Freitas A, Spiller F, Souto FO, Cunha FQ. The role of neutrophils in severe sepsis. Shock (2008) 30(Suppl 1):3-9. doi:10.1097/ SHK.0b013e3181818466

22. Chishti AD, Shenton BK, Kirby JA, Baudouin SV. Neutrophil chemotaxis and receptor expression in clinical septic shock. Intensive Care Med (2004) 30:605-11. doi:10.1007/s00134-004-2175-y

23. Arraes SM, Freitas MS, da Silva SV, de Paula Neto HA, Alves-Filho JC, Auxiliadora Martins M, et al. Impaired neutrophil chemotaxis in sepsis associates with GRK expression and inhibition of actin assembly and tyrosine phosphorylation. Blood (2006) 108:2906-13. doi:10.1182/blood-2006-05-024638

24. Rios-Santos F, Alves-Filho JC, Souto FO, Spiller F, Freitas A, Lotufo CM, et al. Down-regulation of CXCR2 on neutrophils in severe sepsis is mediated by inducible nitric oxide synthase-derived nitric oxide. Am J Respir Crit Care Med (2007) 175:490-7. doi:10.1164/rccm.200601-103OC

25. Tavares-Murta BM, Zaparoli M, Ferreira RB, Silva-Vergara ML, Oliveira $\mathrm{CH}$, Murta EF, et al. Failure of neutrophil chemotactic function in septic patients. Crit Care Med (2002) 30:1056-61. doi:10.1097/ 00003246-200205000-00017

26. Alves-Filho JC, Freitas A, Souto FO, Spiller F, Paula-Neto H, Silva JS, et al. Regulation of chemokine receptor by Toll-like receptor 2 is critical to neutrophil migration and resistance to polymicrobial sepsis. Proc Natl Acad Sci U S A (2009) 106:4018-23. doi:10.1073/pnas.0900196106

27. Secher T, Vasseur V, Poisson DM, Mitchell JA, Cunha FQ, Alves-Filho JC, et al. Crucial role of TNF receptors 1 and 2 in the control of polymicrobial sepsis. J Immunol (2009) 182:7855-64. doi:10.4049/jimmunol.0804008

28. Martin EL, Souza DG, Fagundes CT, Amaral FA, Assenzio B, Puntorieri V, et al. Phosphoinositide-3 kinase gamma activity contributes to sepsis and organ damage by altering neutrophil recruitment. Am J Respir Crit Care Med (2010) 182:762-73. doi:10.1164/rccm.201001-0088OC

29. Paula-Neto HA, Alves-Filho JC, Souto FO, Spiller F, Amendola RS, Freitas A, et al. Inhibition of guanylyl cyclase restores neutrophil migration and maintains bactericidal activity increasing survival in sepsis. Shock (2011) 35:17-27. doi:10.1097/SHK.0b013e3181e37ea8

30. Murdoch C, Finn A. Chemokine receptors and their role in inflammation and infectious diseases. Blood (2000) 95:3032-43.

31. Moore CA, Milano SK, Benovic JL. Regulation of receptor trafficking by GRKs and arrestins. Annu Rev Physiol (2007) 69:451-82. doi:10.1146/annurev. physiol.69.022405.154712

32. Lefkowitz RJ, Shenoy SK. Transduction of receptor signals by beta-arrestins. Science (2005) 308:512-7. doi:10.1126/science.1109237

33. Alves-Filho JC, Sonego F, Souto FO, Freitas A, Verri WA Jr, AuxiliadoraMartins M, et al. Interleukin-33 attenuates sepsis by enhancing neutrophil influx to the site of infection. Nat Med (2010) 16:708-12. doi:10.1038/nm.2156

34. Trevelin SC, Alves-Filho JC, Sonego F, Turato W, Nascimento DC, Souto FO, et al. Toll-like receptor 9 activation in neutrophils impairs chemotaxis and reduces sepsis outcome. Crit Care Med (2012) 40:2631-7. doi:10.1097/ CCM.0b013e318258fb70

35. Lee SK, Kim SD, Kook M, Lee HY, Ghim J, Choi Y, et al. Phospholipase D2 drives mortality in sepsis by inhibiting neutrophil extracellular trap formation and down-regulating CXCR2. J Exp Med (2015) 212:1381-90. doi:10.1084/ jem.20141813

36. Alves-Filho JC, de Freitas A, Russo M, Cunha FQ. Toll-like receptor 4 signaling leads to neutrophil migration impairment in polymicrobial sepsis ${ }^{*}$. Crit Care Med (2006) 34:461-70. doi:10.1097/01.ccm.0000198527.71819.e1

37. Le HT, Tran VG, Kim W, Kim J, Cho HR, Kwon B. IL-33 priming regulates multiple steps of the neutrophil-mediated anti-Candida albicans response 
by modulating TLR and dectin-1 signals. JImmunol (2012) 189:287-95. doi:10.4049/jimmunol.1103564

38. Sonego F, Castanheira FV, Czaikoski PG, Kanashiro A, Souto FO, Franca RO, et al. MyD88-, but not Nod1- and/or Nod2-deficient mice, show increased susceptibility to polymicrobial sepsis due to impaired local inflammatory response. PLoS One (2014) 9:e103734. doi:10.1371/journal.pone.0103734

39. Dal-Secco D, Freitas A, Abreu MA, Garlet TP, Rossi MA, Ferreira SH, et al. Reduction of ICAM-1 expression by carbon monoxide via soluble guanylate cyclase activation accounts for modulation of neutrophil migration. Naunyn Schmiedebergs Arch Pharmacol (2010) 381:483-93. doi:10.1007/ s00210-010-0500-2

40. Cunha FQ, Assreuy J, Moss DW, Rees D, Leal LM, Moncada S, et al. Differential induction of nitric oxide synthase in various organs of the mouse during endotoxaemia: role of TNF-alpha and IL-1-beta. Immunology (1994) 81:211-5.

41. Sakai K, Suzuki H, Oda H, Akaike T, Azuma Y, Murakami T, et al. Phosphoinositide 3-kinase in nitric oxide synthesis in macrophage: critical dimerization of inducible nitric-oxide synthase. J Biol Chem (2006) 281:17736-42. doi:10.1074/jbc.M601896200

42. Szabo C. Hydrogen sulphide and its therapeutic potential. Nat Rev Drug Discov (2007) 6:917-35. doi:10.1038/nrd2425

43. Spiller F, Orrico MI, Nascimento DC, Czaikoski PG, Souto FO, Alves-Filho JC, et al. Hydrogen sulfide improves neutrophil migration and survival in sepsis via K+ATP channel activation. Am J Respir Crit Care Med (2010) 182:360-8. doi:10.1164/rccm.200907-1145OC

44. Mestriner FL, Spiller F, Laure HJ, Souto FO, Tavares-Murta BM, Rosa JC, et al. Acute-phase protein alpha-1-acid glycoprotein mediates neutrophil migration failure in sepsis by a nitric oxide-dependent mechanism. Proc Natl Acad Sci U S A (2007) 104:19595-600. doi:10.1073/pnas.0709681104

45. Torres-Duenas D, Celes MR, Freitas A, Alves-Filho JC, Spiller F, Dal-Secco D, et al. Peroxynitrite mediates the failure of neutrophil migration in severe polymicrobial sepsis in mice. Br J Pharmacol (2007) 152:341-52. doi:10.1038/ sj.bjp.0707393

46. Wu Z, Sawamura T, Kurdowska AK, Ji HL, Idell S, Fu J. LOX-1 deletion improves neutrophil responses, enhances bacterial clearance, and reduces lung injury in a murine polymicrobial sepsis model. Infect Immun (2011) 79:2865-70. doi:10.1128/IAI.01317-10

47. Freitas A, Alves-Filho JC, Victoni T, Secher T, Lemos HP, Sonego F, et al. IL-17 receptor signaling is required to control polymicrobial sepsis. J Immunol (2009) 182:7846-54. doi:10.4049/jimmunol.0803039

48. Reddy RC, Narala VR, Keshamouni VG, Milam JE, Newstead MW, Standiford TJ. Sepsis-induced inhibition of neutrophil chemotaxis is mediated by activation of peroxisome proliferator-activated receptor-\{gamma\}. Blood (2008) 112:4250-8. doi:10.1182/blood-2007-12-128967

49. Ferreira AE, Sisti F, Sonego F, Wang S, Filgueiras LR, Brandt S, et al. PPAR-gamma/IL-10 axis inhibits MyD88 expression and ameliorates murine polymicrobial sepsis. J Immunol (2014) 192:2357-65. doi:10.4049/ jimmunol.1302375

50. Alves-Filho JC, Spiller F, Cunha FQ. Neutrophil paralysis in sepsis. Shock (2010) 34(Suppl 1):15-21. doi:10.1097/SHK.0b013e3181e7e61b

51. Kovach MA, Standiford TJ. The function of neutrophils in sepsis. Curr Opin Infect Dis (2012) 25:321-7. doi:10.1097/QCO.0b013e3283528c9b

52. Hoesel LM, Neff TA, Neff SB, Younger JG, Olle EW, Gao H, et al. Harmful and protective roles of neutrophils in sepsis. Shock (2005) 24:40-7. doi:10.1097/01. shk.0000170353.80318.d5

53. Brown KA, Brain SD, Pearson JD, Edgeworth JD, Lewis SM, Treacher DF. Neutrophils in development of multiple organ failure in sepsis. Lancet (2006) 368:157-69. doi:10.1016/s0140-6736(06)69005-3

54. Zhang S, Rahman M, Qi Z, Thorlacius H. Simvastatin antagonizes CD40L secretion, CXC chemokine formation, and pulmonary infiltration of neutrophils in abdominal sepsis. J Leukoc Biol (2011) 89:735-42. doi:10.1189/ jlb.0510279

55. Hwaiz R, Rahman M, Syk I, Zhang E, Thorlacius H. Rac1-dependent secretion of platelet-derived CCL5 regulates neutrophil recruitment via activation of alveolar macrophages in septic lung injury. J Leukoc Biol (2015) 97:975-84. doi:10.1189/jlb.4A1214-603R

56. Johnston B, Burns AR, Suematsu M, Issekutz TB, Woodman RC, Kubes P. Chronic inflammation upregulates chemokine receptors and induces neutrophil migration to monocyte chemoattractant protein-1. J Clin Invest (1999) 103:1269-76. doi:10.1172/JCI5208
57. Speyer CL, Gao H, Rancilio NJ, Neff TA, Huffnagle GB, Sarma JV, et al. Novel chemokine responsiveness and mobilization of neutrophils during sepsis. Am J Pathol (2004) 165:2187-96. doi:10.1016/S0002-9440(10)63268-3

58. Hartl D, Krauss-Etschmann S, Koller B, Hordijk PL, Kuijpers TW, Hoffmann F, et al. Infiltrated neutrophils acquire novel chemokine receptor expression and chemokine responsiveness in chronic inflammatory lung diseases. J Immunol (2008) 181:8053-67. doi:10.4049/jimmunol.181.11.8053

59. Souto FO, Alves-Filho JC, Turato WM, Auxiliadora-Martins M, Basile - Filho A, Cunha FQ. Essential role of CCR2 in neutrophil tissue infiltration and multiple organ dysfunction in sepsis. Am J Respir Crit Care Med (2011) 183:234-42. doi:10.1164/rccm.201003-0416OC

60. Talbot J, Bianchini FJ, Nascimento DC, Oliveira RD, Souto FO, Pinto LG, et al. CCR2 expression in neutrophils plays a critical role in their migration into the joints in rheumatoid arthritis. Arthritis Rheumatol (2015) 67:1751-9. doi:10.1002/art.39117

61. Brinkmann V, Reichard U, Goosmann C, Fauler B, Uhlemann Y, Weiss DS, et al. Neutrophil extracellular traps kill bacteria. Science (2004) 303:1532-5. doi:10.1126/science. 1092385

62. Luo L, Zhang S, Wang Y, Rahman M, Syk I, Zhang E, et al. Proinflammatory role of neutrophil extracellular traps in abdominal sepsis. Am J Physiol Lung Cell Mol Physiol (2014) 307:L586-96. doi:10.1152/ajplung.00365.2013

63. Martinod K, Fuchs TA, Zitomersky NL, Wong SL, Demers M, Gallant M, et al. PAD4-deficiency does not affect bacteremia in polymicrobial sepsis and ameliorates endotoxemic shock. Blood (2015) 125:1948-56. doi:10.1182/ blood-2014-07-587709

64. McDonald B, Urrutia R, Yipp BG, Jenne CN, Kubes P. Intravascular neutrophil extracellular traps capture bacteria from the bloodstream during sepsis. Cell Host Microbe (2012) 12:324-33. doi:10.1016/j.chom.2012.06.011

65. Czaikoski PG, Mota JM, Nascimento DC, Sonego F, Castanheira FV, Melo PH, et al. Neutrophil extracellular traps induce organ damage during experimental and clinical sepsis. PLoS One (2016) 11:e0148142. doi:10.1371/journal. pone. 0148142

66. Liu FC, Chuang YH, Tsai YF, Yu HP. Role of neutrophil extracellular traps following injury. Shock (2014) 41:491-8. doi:10.1097/shk. 0000000000000146

67. Gupta AK, Joshi MB, Philippova M, Erne P, Hasler P, Hahn S, et al. Activated endothelial cells induce neutrophil extracellular traps and are susceptible to NETosis-mediated cell death. FEBS Lett (2010) 584:3193-7. doi:10.1016/j. febslet.2010.06.006

68. Gao X, Hao S, Yan H, Ding W, Li K, Li J. Neutrophil extracellular traps contribute to the intestine damage in endotoxemic rats. J Surg Res (2015) 195:211-8. doi:10.1016/j.jss.2014.12.019

69. Tanaka K, Koike Y, Shimura T, Okigami M, Ide S, Toiyama Y, et al. In vivo characterization of neutrophil extracellular traps in various organs of a murine sepsis model. PLoS One (2014) 9:e111888. doi:10.1371/journal. pone. 0111888

70. Clark SR, Ma AC, Tavener SA, McDonald B, Goodarzi Z, Kelly MM, et al. Platelet TLR4 activates neutrophil extracellular traps to ensnare bacteria in septic blood. Nat Med (2007) 13:463-9. doi:10.1038/nm1565

71. Scheibner KA, Lutz MA, Boodoo S, Fenton MJ, Powell JD, Horton MR. Hyaluronan fragments act as an endogenous danger signal by engaging TLR2. J Immunol (2006) 177:1272-81. doi:10.4049/jimmunol.177.2.1272

72. Xu J, Zhang X, Pelayo R, Monestier M, Ammollo CT, Semeraro F, et al. Extracellular histones are major mediators of death in sepsis. Nat Med (2009) 15:1318-21. doi:10.1038/nm.2053

73. Allam R, Scherbaum CR, Darisipudi MN, Mulay SR, Hagele H, Lichtnekert J, et al. Histones from dying renal cells aggravate kidney injury via TLR2 and TLR4. JAm Soc Nephrol (2012) 23:1375-88. doi:10.1681/ asn. 2011111077

74. Saffarzadeh M, Juenemann C, Queisser MA, Lochnit G, Barreto G, Galuska SP, et al. Neutrophil extracellular traps directly induce epithelial and endothelial cell death: a predominant role of histones. PLoS One (2012) 7:e32366. doi:10.1371/journal.pone.0032366

75. Brealey D, Singer M. Multi-organ dysfunction in the critically ill: effects on different organs. JR Coll Physicians Lond (2000) 34:428-31. doi:10.7861/ jroycollphys.34-5-428

76. Windsor AC, Mullen PG, Fowler AA, Sugerman HJ. Role of the neutrophil in adult respiratory distress syndrome. Br J Surg (1993) 80:10-7. doi:10.1002/ bjs. 1800800106 
77. Astiz ME, DeGent GE, Lin RY, Rackow EC. Microvascular function and rheologic changes in hyperdynamic sepsis. Crit Care Med (1995) 23:265-71. doi:10.1097/00003246-199502000-00011

78. Fink MP, Evans TW. Mechanisms of organ dysfunction in critical illness: report from a Round Table Conference held in Brussels. Intensive Care Med (2002) 28:369-75. doi:10.1007/s00134-001-1205-2

79. Aird WC. The role of the endothelium in severe sepsis and multiple organ dysfunction syndrome. Blood (2003) 101:3765-77. doi:10.1182/ blood-2002-06-1887

80. Rees DD, Monkhouse JE, Cambridge D, Moncada S. Nitric oxide and the haemodynamic profile of endotoxin shock in the conscious mouse. Br J Pharmacol (1998) 124:540-6. doi:10.1038/sj.bjp.0701815

81. Kooy NW, Lewis SJ, Royall JA, Ye YZ, Kelly DR, Beckman JS. Extensive tyrosine nitration in human myocardial inflammation: evidence for the presence of peroxynitrite. Crit Care Med (1997) 25:812-9. doi:10.1097/00003246199705000-00017

Conflict of Interest Statement: The authors declare the absence of any commercial or financial relationships that could be construed as a potential conflict of interest.

Copyright (C) 2016 Sônego, Castanheira, Ferreira, Kanashiro, Leite, Nascimento, Colón, Borges, Alves-Filho and Cunha. This is an open-access article distributed under the terms of the Creative Commons Attribution License (CC BY). The use, distribution or reproduction in other forums is permitted, provided the original author(s) or licensor are credited and that the original publication in this journal is cited, in accordance with accepted academic practice. No use, distribution or reproduction is permitted which does not comply with these terms. 

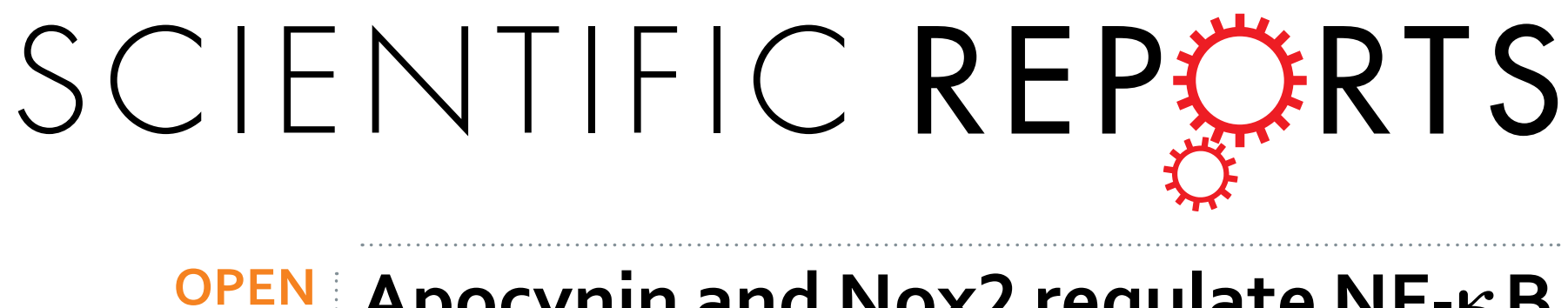

\section{Apocynin and Nox2 regulate NF- $\kappa B$ by modifying thioredoxin-1 redox- state}

Received: 17 May 2016

Accepted: 16 September 2016

Published: 04 October 2016
Silvia Cellone Trevelin ${ }^{1,2,3}$, Célio Xavier dos Santos ${ }^{3}$, Raphael Gomes Ferreira ${ }^{1}$, Larissa de Sá Lima ${ }^{2}$, Rangel Leal Silva ${ }^{1}$, Cristoforo Scavone ${ }^{2}$, Rui Curi ${ }^{4}$, José Carlos Alves-Filho ${ }^{1}$, Thiago Mattar Cunha ${ }^{1}$, Pérsio Roxo-Júnior ${ }^{5}$, Maria-Célia Cervi ${ }^{5}$, Francisco Rafael Martins Laurindo ${ }^{6}$, John Stephen Hothersall ${ }^{1}$, Andrew M. Cobb ${ }^{3}$, Min Zhang ${ }^{3}$, Aleksandar Ivetic ${ }^{3}$, Ajay M. Shah ${ }^{3}$, Lucia Rossetti Lopes ${ }^{2, *}$ \& Fernando Queiroz Cunha ${ }^{1, *}$

The reactive-oxygen-species-(ROS)-generating-enzyme Nox 2 is essential for leukocyte anti-microbial activity. However its role in cellular redox homeostasis and, consequently, in modulating intracellular signaling pathways remains unclear. Herein, we show Nox2 activation favors thioredoxin-1 (TRX-1)/ p40phox interaction, which leads to exclusion of TRX-1 from the nucleus. In contrast, the genetic deficiency of Nox2 or its pharmacological inhibition with apocynin (APO) results in reductive stress after lipopolysaccharide-(LPS)-cell stimulation, which causes nuclear accumulation of TRX-1 and enhanced transcription of inflammatory mediators through nuclear-factor-(NF)- $\kappa B$. The NF- $\kappa B$ overactivation is prevented by TRX-1 oxidation using inhibitors of thioredoxin reductase-1 (TrXR-1). The Nox2/TRX-1/ $\mathrm{NF}-\kappa B$ intracellular signaling pathway is involved in the pathophysiology of chronic granulomatous disease (CGD) and sepsis. In fact, TrxR-1 inhibition prevents nuclear accumulation of TRX-1 and LPSstimulated hyperproduction of tumor-necrosis-factor-(TNF)- $\alpha$ by monocytes and neutrophils purified from blood of CGD patients, who have deficient Nox2 activity. TrxR-1 inhibitors, either lanthanum chloride $\left(\mathrm{LaCl}_{3}\right)$ or auranofin (AUR), also increase survival rates of mice undergoing cecal-ligation-andpuncture-(CLP). Therefore, our results identify a hitherto unrecognized Nox2-mediated intracellular signaling pathway that contributes to hyperinflammation in CGD and in septic patients. Additionally, we suggest that TrxR-1 inhibitors could be potential drugs to treat patients with sepsis, particularly in those with CGD.

Reactive oxygen species (ROS) generated by Nox2 play a vital role in the killing of phagocytized microorganisms. Actually, patients with deficient Nox2 activity due to mutations in oxidase subunits suffer from chronic granulomatous disease (CGD), a condition in which there is increased susceptibility to bacterial and fungal infections ${ }^{1}$. In addition to the key role of Nox 2 in the control of infection, there is evidence that Nox 2 could limit inflammatory response. For instance, Nox2-deficient mice have higher neutrophil recruitment in a model of thioglycollate-induced peritonitis ${ }^{2}$ or $\beta$-glucan ear injection ${ }^{3}$ and increased release of inflammatory mediators in a model of intraperitoneal zymosan challenge ${ }^{4}$. Acute lung injury was also aggravated in mice deficient in $\mathrm{p} 47$ phagocyte oxidase (p47phox), a Nox 2 subunit ${ }^{5}$. Corroborating the animal models, monocytes from CGD patients exhibit increased lipopolysaccharide-(LPS)-stimulated production of several pro-inflammatory cytokines, such as CCL2, CXCL2, TNF- $\alpha$ and interleukine-[IL]-1 $\beta^{6}$. Furthermore, CGD patients develop aseptic granulomas in several organs, but the underlying molecular mechanism is poorly understood ${ }^{1}$.

\footnotetext{
${ }^{1}$ Department of Pharmacology, Ribeirao Preto Medical School, University of Sao Paulo, Ribeirão Preto, Brazil. ${ }^{2}$ Department of Pharmacology, Institute of Biomedical Sciences, University of Sao Paulo, São Paulo, Brazil. ' ${ }^{3}$ ing's College London, British Heart Foundation Centre, Cardiovascular Division, London, United Kingdom. ${ }^{4}$ Department of Biophysics and Physiology, Institute of Biomedical Sciences, University of Sao Paulo, São Paulo, Brazil. ${ }^{5}$ Department of Pediatrics, Ribeirao Preto Medical School, University of Sao Paulo, Ribeirão Preto, Brazil. ${ }^{6}$ Heart Institute, School of Medicine, University of Sao Paulo, São Paulo, Brazil. *These authors contributed equally to this work. Correspondence and requests for materials should be addressed to L.R.L. (email: llopes@usp.br) or F.Q.C. (email: fdqcunha@fmrp.usp.br)
} 
Nox2 activation involves the assembly of a multi-subunit complex in which cytosolic p47phox, p40phox and p67phox subunits translocate to a membrane-bound heterodimer comprising the Nox2 catalytic subunit (also known as gp91phox) and a 22 phox subunit. The activated enzyme catalyzes electron transfer from nicotinamide adenine dinucleotide phosphate hydrogenated (NADPH) to molecular oxygen, thereby generating superoxide and subsequently other ROS ${ }^{7}$.

Enzymatically derived oligophenols from the peroxidase-catalysed oxidation of apocynin (APO) can be effective inhibitors of Nox $2^{8}$. A previous study demonstrated that APO-trimmer, generate by myeloperoxidase from phagocytes, oxidizes the cysteine residue 196 (Cys196) of p47phox, which impairs its assembly with p22phox ${ }^{9}$.

Although there are no inhibitors of Nox2 directly targeting p40phox, it is a key subunit for Nox 2 activation. Neutrophils deficient of p40phox have $85 \%$ reduced ROS generation induced by $S$. aureus and IgG-latex beads. In fact, after the cell stimulation, p40phox and p47phox together interact with p67phox and scaffold this subunit on the cell membrane (through phox homology domain $[\mathrm{PX}]$ ) close to gp91phox ${ }^{10}$. In addition to the regulatory role of p40phox in Nox2 activation, this subunit was also identified as a thioredoxin-1 (TRX-1) binding protein in a yeast two-hybrid-system screen ${ }^{11}$. However, the consequences of this interaction in intracellular signaling pathways have not being investigated.

TRX-1 is a $12 \mathrm{KDa}$-protein responsible for cell redox homeostasis. It contains an active disulfide/dithiol within the conserved sequence Cys-Gly-Pro-Cys, which allows TRX-1 to operate as a reducing system in association with the selenoprotein thioredoxin reductase-1 (TrxR-1) and NADPH ${ }^{12}$. Inside the nucleus, TRX-1 in its reduced state has the ability to potentiate the binding of transcription factors to DNA ${ }^{12}$.

Nuclear factor-(NF)- $\kappa$ B is one of the systems regulated by TRX-1 ${ }^{13}$. The NF- $\kappa B$ subunits p50 and p65 are normally sequestered in the cytoplasm through their tight association with I $\kappa$ B- $\alpha$ protein. After stimuli, for instance the activation of the toll-like-receptor 4 (TLR4) by LPS, I $\mathrm{B}-\alpha$ phosphorylation leads to its proteasomal-degradation and allows the NF- $\kappa$ B subunits to translocate to the nucleus. In the nucleus, p50 and p65 undergo several post-translational modifications, including the reduction of cysteine residues by TRX-1, which leads to their binding to DNA and transcription of several proteins, such as inflammatory mediators and TLRs $^{12-14}$

In this study, we investigated the interaction between TRX-1 and p40phox after Nox 2 activation, and evaluated how changes in TRX-1 redox state induced by Nox 2 or APO treatment regulate NF- $\kappa$ B in the settings of CGD and sepsis.

\section{Results}

The activated Nox 2 complex associates with TRX-1 through p40phox. To assess the relationship between Nox 2 and TRX-1, the intracellular localization of these proteins was firstly evaluated in leukocytes by using confocal microscopy. LPS stimuli induced the colocalization of gp91phox (Nox2) and TRX-1 outside the nucleus both in RAW 264.7 cells and mouse peritoneal macrophages (Fig. 1A and Supplementary Fig. 1A). Since p40phox and p67phox associate with gp91phox in a protein complex ${ }^{7}$, RAW264.7 cell lysates were subjected to sucrose gradient centrifugation to generate sequential fractions containing TRX-1 and these Nox 2 subunits. TRX-1 was recovered predominantly in gels containing fractions 9 and higher (Supplementary Fig. 1B), which were then analyzed for the presence of $\mathrm{p} 40 \mathrm{phox}$, gp91phox (the mouse fully glycosylated form runs with an apparent molecular weight of $58 \mathrm{KDa}$ ) and p67phox. Under baseline conditions, there was a modest overlap between TRX-1 and Nox2 subunits whereas lysates of LPS-stimulated cells showed a substantial proportion of TRX-1, gp91phox, p40phox and p67phox recovered in the same sucrose gradient fractions, consistent with the notion that protein association mainly occurs when Nox2 is activated (Fig. 1B). As controls, albumin and cytochrome c, which have comparable molecular weights to gp91phox and TRX-1 respectively, were found in distinctly separate fractions (Supplementary Fig. 1C). When cell lysates were treated with N-ethylmaleimide (NEM, the thiol alkylating agent that blocks all cysteine residues of proteins ${ }^{15}$ ), Nox2 (gp91phox) and TRX-1 were no longer recovered in the same fractions (Supplementary Fig. 1D), indicating a redox dependent interaction. In order to identify which Nox2 subunit directly interacts with TRX-1 after LPS stimuli, immunoprecipitation assays were performed in RAW cells lysates. Anti-TRX-1 antibody failed to recover gp91phox (Fig. 1C) and neither TRX-1 was recovered in anti-myc immunoprecipitates of HEK293T cells transfected with Nox2-(gp91phox)-myc and native TRX-1 (Supplementary Fig. 1E). However, p40phox was co-immunoprecipitated with TRX-1 in RAW264.7 cell lysates (Fig. 1C). Furthermore, native TRX-1 could be co-precipitated with p40phox in anti-green-fluorescent-protein-(GFP) immunoprecipitates of HEK293T cells transfected with p40phox-GFP (Fig. 1D). Reinforcing the results obtained from sucrose gradient fractionation of NEM-incubated samples, a TRX-1 mutant in that serine residues replaced Cys32 and Cys35 did not interact with p40phox (Fig. 1D). These combined results suggest that thiol redox-regulation of active cysteine residues of TRX-1 by Nox 2 is essential for its interaction with p40phox.

The localization of TRX-1 in cells lacking functional Nox2 was next analyzed. APO was used as an inhibitor of Nox2 in RAW264.7 cells. In fact, APO significantly impaired the colocalization of p47phox and Nox2 (gp91phox) after LPS-stimulation, and almost abolished the ROS generation stimulated by opsonized zymosan (Supplementary Fig. 2A,B). The colocalization of Nox2 (gp91phox) and TRX-1 was not observed in LPS-stimulated RAW264.7 cells treated with APO and macrophages from Nox2 ${ }^{-/ y}$ mice (chromosome X-linked genetic deficiency of Nox2), and instead there was a nuclear accumulation of TRX-1 (Fig. 1E and Supplementary Fig. 1F). Moreover, the addition of $\mathrm{H}_{2} \mathrm{O}_{2}$ was sufficient to prevent this last response in macrophages from Nox $2^{- \text {y }}$ mice (Fig. 1E).

Therefore, after LPS stimulation, TRX-1 interacts with the activated Nox 2 complex through p40phox, thereby preventing its nuclear accumulation.

APO modifies the TRX-1 redox-state and increases NF- $\kappa$ B binding to DNA through Nox 2 inhi-

bition. Mammalian TRX-1 has three non-active cysteine residues (Cys62, Cys69, and Cys73) in addition to 
A

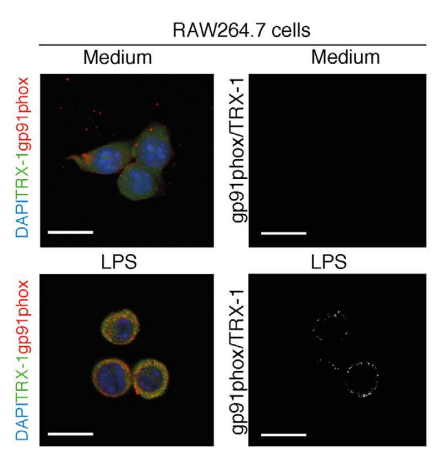

$\mathrm{E}$

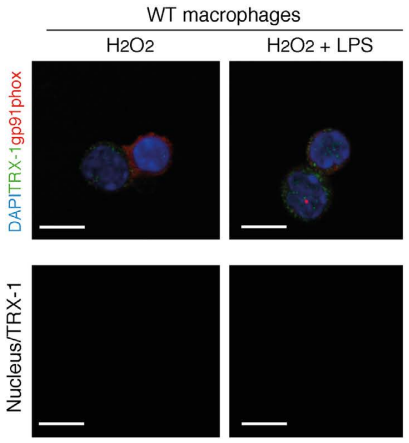

B

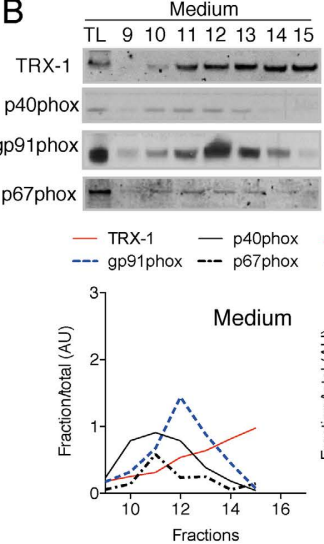

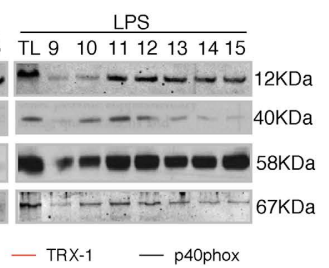

--- gp91phox --- p40phox

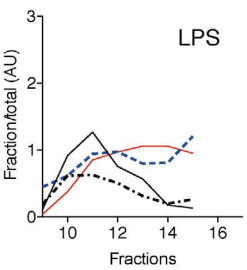

C

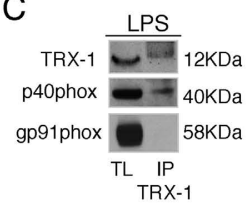

$\mathrm{D}$

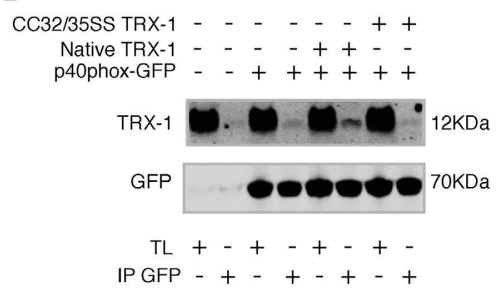

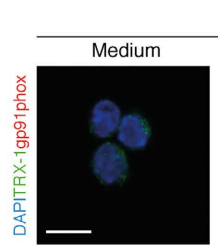

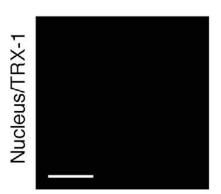

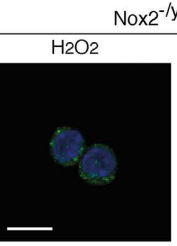

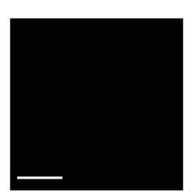

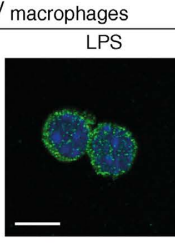

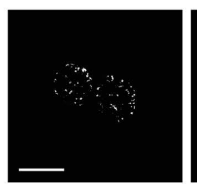

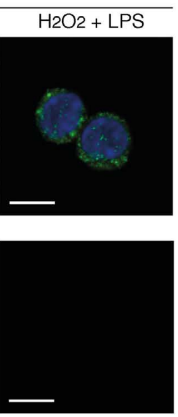

Figure 1. Nox2 activation facilitates thioredoxin-1 (TRX-1) and p40phox interaction and prevents nuclear accumulation of TRX-1. (A) TRX-1 (green) and Nox2/gp91phox (red) in RAW264.7 cells stimulated with LPS (10 ng/ml, 30 minutes). Nuclear material was stained with DAPI (blue). Images were obtained by confocal microscopy (63X objective; 5X magnification) and represent three independent experiments realized in triplet. Colocalization is highligted in white/black image. Scale bars, $7.5 \mu \mathrm{m}$. (B) Sucrose gradient cell fractionation and densitometry. Immunoblots (IB) were performed for TRX-1, p40phox, gp91phox and p67phox in fractions 9 to 15. AU: arbitrary units. (C) Immunoprecipitation (IP) was performed with anti-TRX-1 antibody (Ab) in total cell lysates and IB for p40phox, gp91phox and TRX-1. (D) HEK293T cells were transfected with p40phox-GFP and either native TRX-1 or mutated CC32/35SS TRX-1. IP was performed with anti-GFP Ab and IB for GFP and TRX-1. Blots represent three independent experiments. TL: total cell lysate. (E) Macrophages harvested from WT and Nox $2^{-/ y}$ mice were stimulated with LPS. Some cells were treated with hydrogen peroxide $\left(\mathrm{H}_{2} \mathrm{O}_{2}\right.$, $10 \mu \mathrm{M})$. Scale bars, $7.5 \mu \mathrm{m}$. The results are expressed as the means of fluorescence intensity (MFI) \pm standard error of the mean (SEM) obtained by analyzing 15 nucleus-TRX-1 colocalizations (white) per group. Black continuous and dashed lines respectively indicate the average values obtained by analysing WT and Nox $2^{-/ y}$ cells in medium only. Full-lengh blots are showed in Supplementary Figs 10 and 11 . ${ }^{\star} P<0.05$ as compared to WT cells incubated with LPS; ${ }^{\dagger} P<0.05$ as compared to Nox $2^{-/ y}$ cells incubated with LPS.

two redox-active cysteine residues (Cys32-Cys35). Therefore, mouse TRX-1 can assume several oxidation states that are poorly visualized in a redox immunoblotting analysis, whereas TRX-1 in a fully reduced state is clearly resolved $^{16,17}$. After alkylation (blocking) of thiols with iodoacetic acid and then analysis on native polyacrylamide gels, lysates of RAW264.7 cells pre-treated with APO and stimulated with LPS showed significantly higher levels of reduced TRX-1 as compared to lysates of cells incubated with LPS only (Fig. 2A). Lysates from DTT(dithiothreitol, reducing agent)-treated cells were used as positive controls for reduced TRX-15. There was no difference in total TRX-1 protein levels evaluated by conventional immunoblotting methods (Fig. 2B).

Because TRX-1 redox-state was modified by APO treatment and this reductase is recognized as an important modulator of cell redox homeostasis ${ }^{18}$, we reasoned that Nox 2 inhibition or its genetic deficiency would result in a more reduced intracellular environment and hence higher levels of free thiol groups. Iodoacetamide conjugated to isothiocyanate fluorescein (IAM-FITC) was used as an alkylating agent that interacts with free thiol groups ${ }^{15}$. Cells incubated with DTT and 5,5'-dithiobis-2-nitrobenzoic acid (DTNB, oxidizing agent) were used as controls. LPS-stimulated RAW264.7 cells treated with APO showed a substantial increase in IAM-FITC fluorescence as assessed by confocal microscopy and flow cytometry (Fig. 2C and Supplementary Fig. 3A). Similar results were observed in macrophages from Nox $2^{-/ y}$ mice stimulated with LPS (Supplementary Fig. 3B). Of note, APO plus LPS-treated Nox $2^{-/ y}$ macrophages showed IAM-FITC staining comparable to that presented by LPS-treated Nox $2^{-/ y}$ cells (Supplementary Fig. 3B), indicating that APO per se does not change cellular redox state independently of Nox2 inhibition. Consistent with the IAM-FITC assay, reduced glutathione (GSH) levels were 
A

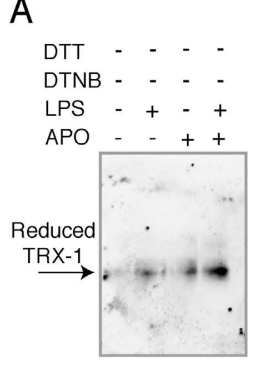

D

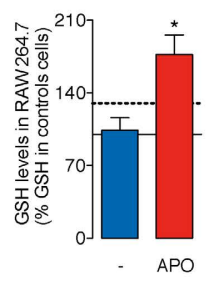

B
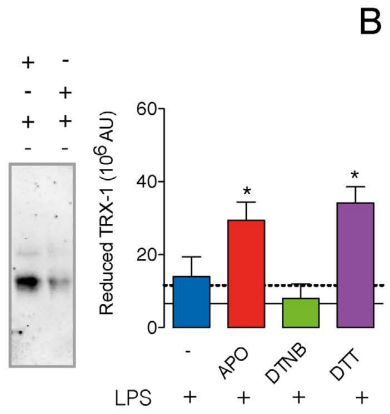

$\mathrm{E}$

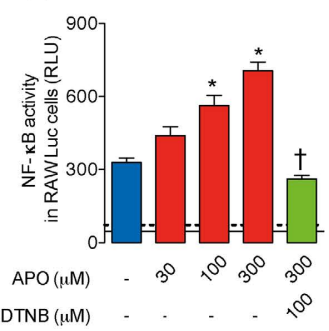

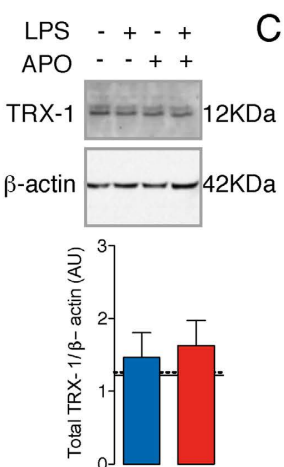

APO

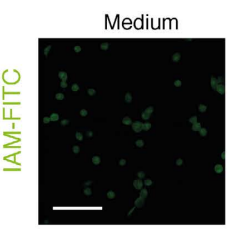

LPS
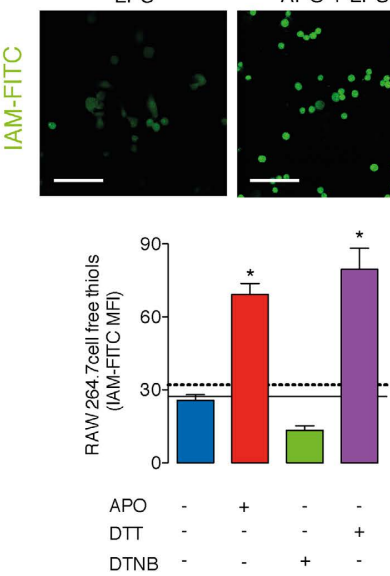

DTNB

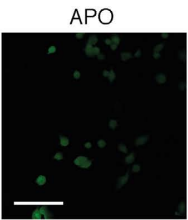

$\mathrm{APO}+\mathrm{LPS}$

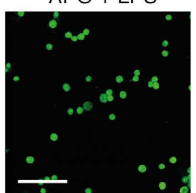

DTT

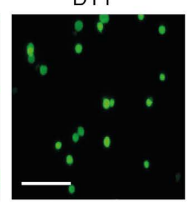

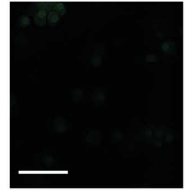

Figure 2. Inhibition of Nox 2 by APO results in TRX-1 reduction and in a reductive stress after LPS stimuli. RAW264.7 cells were incubated with APO $(300 \mu \mathrm{M}$, one hour) and stimulated with LPS ( $10 \mathrm{ng} / \mathrm{ml}, 30$ minutes). Some cells were incubated with 5,5'-dithiobis-2-nitrobenzoic acid (DTNB, $100 \mu \mathrm{M}$ ) or dithiothreitol (DTT, $300 \mu \mathrm{M})$. Immunoblotting was performed under native $(\mathbf{A})$ or reducing condition $(\mathbf{B})$. Densitometry of three independent experiments. The results are expressed as the means \pm SEM. AU: arbitrary units. (C) Levels of free thiols were determined by using IAM-FITC (green). The results are expressed as the means of fluorescence intensity (MFI) \pm SEM obtained by analyzing 15-20 cells/group. Scale bars, $50 \mu \mathrm{m}$. (D) Levels of reduced glutathione (GSH) in total cell lysates. (E) RAW264.7-Luc cells were incubated with APO and then stimulated with LPS (10 ng/ml, four hours). Some cells were incubated with DTNB 30 minutes before the addition of APO. RLU: relative lumen units. Black continuous and dashed lines respectively indicate the average values obtained by analysing cells incubated in medium or after APO-treatment only. The results are expressed as the means \pm SEM ( $n=6$ /group, samples incubated with LPS; $n=3$ /group, samples without LPS). Full-lengh blots of the (B) are showed in Supplementary Fig. 12A. ${ }^{\star} P<0.05$ as compared to cells incubated with LPS; ${ }^{\dagger} P<0.05$ as compared to LPS-stimulated cells pre-incubated with APO.

increased in the LPS-stimulated RAW264.7 cells pre-treated with APO as compared to cells under LPS stimuli only (Fig. 2D).

Disturbances in NF- $\kappa B$ activation were further investigated as consequences of the lack of cell redox homeostasis. In fact, LPS-induced NF- $\kappa$ B activity was inhibited by DTNB oxidizing agent and enhanced by DTT reducing agent in a luciferase reporter assay using RAW264.7-Luc cells (Supplementary Fig. 3C), which is in accordance with a previous study ${ }^{19}$. Similarly to the DTT effect on NF- $\kappa B$, the reductive stress ${ }^{20}$ resulting from APO-treatment potentiated LPS-induced NF- $\kappa B$ activation in a concentration-dependent manner (Fig. 2E). Moreover, the effect of the highest concentration of APO was prevented by cellular oxidation with DTNB (Fig. 2E). Importantly, none of the agents employed in this study affected cell viability (Supplementary Fig. 3D).

To further define the molecular mechanism through which inhibition of Nox2 enhances NF- $\kappa B$ activation, I $\kappa$ B- $\alpha$ degradation and the nuclear translocation of the p65 NF- $\kappa$ B subunit in LPS-stimulated RAW264.7 cells were monitored. Treatment with APO had no significant effect on I $\mathrm{B}-\alpha$ degradation or $\mathrm{p} 65$ translocation (Fig. 3A,B), suggesting that Nox2 is not acting upstream of these steps. However, NF- $\kappa B$ binding to DNA was enhanced by APO in LPS-stimulated cells, as assessed by an electrophoretic mobility shift assay (EMSA) under non-reducing conditions (i.e. in the absence of DTT). When EMSA was performed under reducing conditions, NF- $\kappa B$ binding to DNA was enhanced independently of Nox2 inhibition (Fig. 3C). A specific non-radioactive probe was used as a control in the EMSA assay; and anti-p65 and anti-p50 NF- $\kappa \mathrm{B}$ antibodies favored the super-shift in nuclear extracts of LPS-stimulated cells (Supplementary Fig. 4). In line with an over activation of NF- $\kappa$ B after Nox2 inhibition, LPS-stimulated RAW264.7 cells pre-incubated with APO had increased TLR4 expression and higher TNF- $\alpha$ production than cells in LPS only. These two responses were prevented by DTNB and mimicked those of DTT (Fig. 3D,E). Corroborating our results obtained with leukocytes treated with APO, neutrophils and macrophages purified from Nox $2^{-/ y}$ mice had higher transcription of inflammatory molecules (TNF- $\alpha$, TLR4) induced by LPS as compared to cells of WT mice (Supplementary Fig. 5A-D). Also consistent with our data, the LPS-induced TLR4 expression in leukocytes from Nox $2^{-/ y}$ mice was prevented by incubation

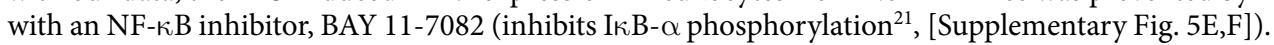

Since thioredoxin reductase-1 (TrxR-1) is the enzyme responsible for reduction of TRX-1 in the cytoplasm ${ }^{22,23}$, we further investigated whether TrxR-1 inhibition, and the consequent redox shift of TRX-1 from its reduced to oxidized state, could prevent the APO-induced NF- $\kappa$ B over activation. In fact, LPS-stimulated RAW264.7-Luc 
A

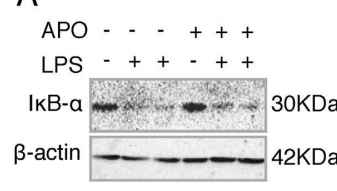

C Reducing Non- reducing

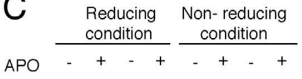

APO +++
LPS - + + + + + ++

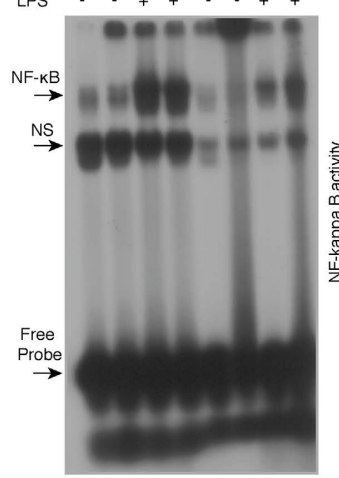

B
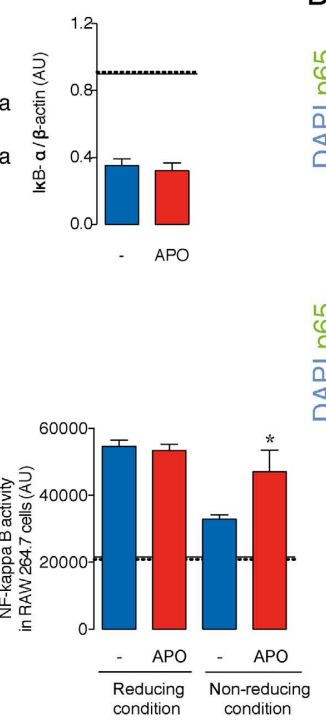

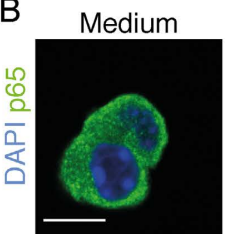

APO

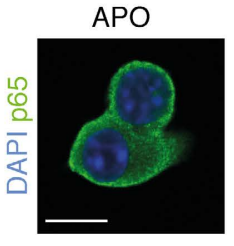

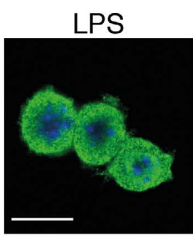

APO+ LPS

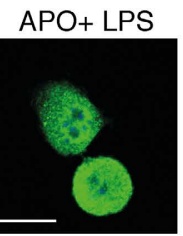

Medium

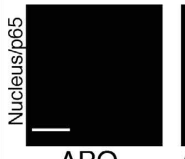

APO
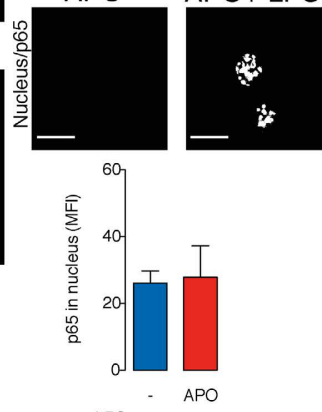

$+$

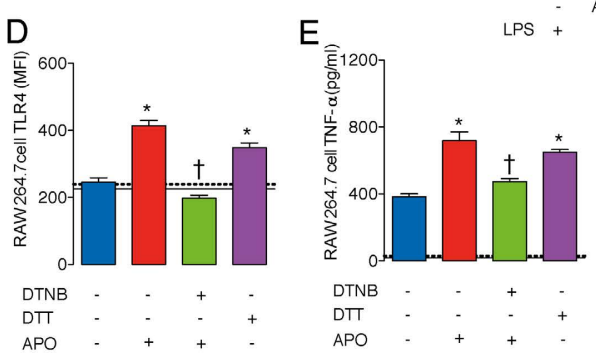

Figure 3. Inhibition of Nox 2 by APO increases LPS-mediated NF- $\kappa$ B binding to DNA. RAW264.7 cells were incubated with APO ( $300 \mu \mathrm{M}$, one hour) and then stimulated with LPS (10 ng/ml, 30 minutes). (A) Degradation of I $\kappa$ B- $\alpha, 15$ minutes after LPS. Densitometry of three independent experiments. AU: arbitrary units. (B) Translocation of p65 (green) to nucleus (blue), 30 minutes after LPS. Images were acquired by confocal microscopy (63X objective; $5 \mathrm{X}$ magnification). Scale bars, $7.5 \mu \mathrm{m}$. The results are expressed as the means of fluorescence intensity (MIF) \pm SEM obtained by analysing 15 nucleus-TRX-1 colocalizations (white) per group. (C) Eletromobility shift assay (EMSA) under reducing (plus DTT, $1 \mathrm{mM}$ ) or non-reducing conditions. NS: non-specific. (D) TLR4 expression by flow cytometry, 12 hours after LPS. (E) TNF- $\alpha$ levels in culture supernatants (ELISA), 12 hours after LPS. The results are expressed as the means \pm SEM ( $n=6$ /group, samples incubated with LPS; $n=3$ /group, samples without LPS). Black continuous and dashed lines respectively indicate the average values obtained by analysing cells incubated in medium or after APO-treatment only. Full-lengh blots of the (A) are showed in Supplementary Fig. 12B. ${ }^{\star} P<0.05$ as compared to cells incubated with LPS; ${ }^{\dagger} P<0.05$ as compared to LPS-stimulated cells pre- incubated with APO.

cells treated with APO and pre-incubated with auranofin (AUR, which blocks the selenocysteine 496 of TrxR-122) or lanthanum chloride $\left(\mathrm{LaCl}_{3}\right.$, which inhibits the NADPH interaction site of TrxR-1 $\left.{ }^{23}\right)$, showed a markedly lower NF- $\kappa$ B activation than cells treated with APO alone (Fig. 4A,B). Moreover, lysates from APO plus LPS-treated cells showed higher TRX-1-mediated reductase activity than lysates from cells in LPS only, which was prevented by $\mathrm{LaCl}_{3}$ (Fig. 4C). This latter result confirmed the APO induction of the reductive stress after LPS incubation through augmentation of reduced TRX-1 levels, as well as the ability of $\mathrm{LaCl}_{3}$ to prevent this altered cellular redox-status.

Ebselen is an organoselenium compound previously associated with inhibition of Nox 2 by preventing the assembly of p47phox and p22phox ${ }^{24}$. However, this drug is also able to competitively antagonize TrxR-1 or even directly oxidizes TRX-125. At lower concentrations $(0.1$ to $1 \mu \mathrm{M})$, ebselen increased NF- $\kappa$ B activation, similar to APO, which could be associated with inhibition of Nox2 (Fig. 4D). In contrast, at higher concentrations (10 to $30 \mu \mathrm{M})$, ebselen did not change or inhibit NF- $\kappa$ B activation, corresponding to antagonism of TrxR-1 and/or oxidation of TRX-1 (Fig. 4D). Importantly, ebselen at $30 \mu \mathrm{M}$ decreased TRX-1-mediated reductase activity of RAW264.7 cells with or without LPS stimuli (Supplementary Fig. 6).

TrxR-1 inhibition prevents the aberrant TNF- $\alpha$ production by LPS-stimulated leukocytes from CGD patients. The relevance of the Nox2/TRX-1/NF- $\kappa$ B intracellular signaling pathway was investigated in humans using leukocytes from healthy controls (HC) and patients with CGD (Supplementary Table S1). LPS-stimulated neutrophils and monocytes from CGD patients showed a substantially higher thiol reduced state than those isolated from HC (Fig. 5A and Supplementary Fig. 7). As in murine cells, LPS stimulation induced the colocalization of Nox 2 and TRX-1 in neutrophils of HC, whilst there was a nuclear accumulation of TRX-1 in cells of CGD patients (Fig. 5B). The higher levels of TRX-1 in the nucleus were in line with an enhanced LPS-stimulated production of TNF- $\alpha$ by cells from CGD patients as compared to those from HC (Fig. 5C,D). Furthermore, treatment of neutrophils of CGD individuals with $\mathrm{LaCl}_{3}$ (TrxR-1 inhibitor) prevented the nuclear 
A

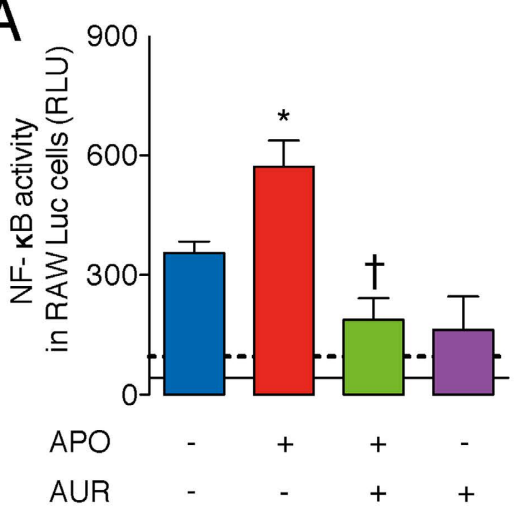

C

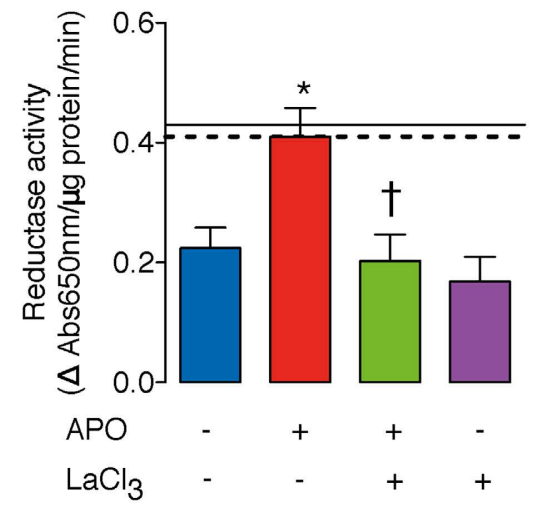

B

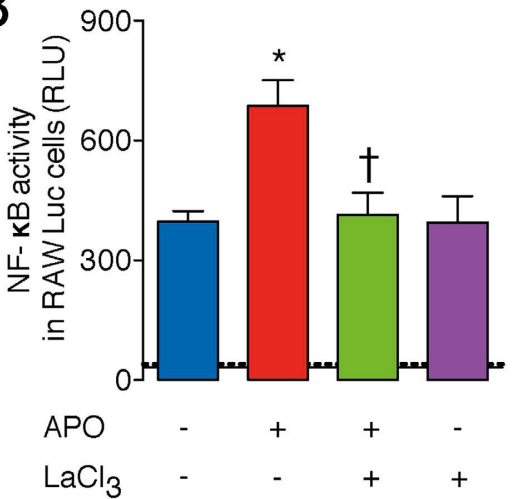

Figure 4. TrxR-1 inhibition prevents the LPS-mediated NF- $\kappa$ B over activation induced by APO. RAW264.7-Luc cells were incubated with APO $(300 \mu \mathrm{M}$, one hour) and then stimulated with LPS $(10 \mathrm{ng} / \mathrm{ml}$, four hours). (A,B) Cells incubated with the TrxR-1 inhibitors, auranofin (AUR, $1 \mu \mathrm{M}-[\mathrm{A}]$ ) or lanthanum chloride $\left(\mathrm{LaCl}_{3}, 1 \mu \mathrm{M}\right.$ - [B]), for 30 minutes before APO. RLU: relative lumen units. (C) Reductase activity of cell lysates 30 minutes after LPS. (D) Cells were incubated with ebselen one hour before LPS. The results are expressed as the means \pm SEM ( $n=6$ /group, samples incubated with LPS; $n=3$ /group, samples without LPS). Black continuous and dashed lines indicate the average values obtained by analysing cells incubated in medium or APO-treatment (or ebselen-treatment $30 \mu \mathrm{M}$ in (D), respectively. ${ }^{\star} P<0.05$ as compared to cells incubated with LPS; ${ }^{\dagger} P<0.05$ as compared to LPS-stimulated cells pre- incubated with APO.

accumulation of TRX-1, and, as a consequence, decreased the LPS-stimulated production of TNF- $\alpha$ (Fig. 5B,D). $\mathrm{LaCl}_{3}$ also prevented the aberrant TNF- $\alpha$ production by monocytes from CGD subjects (Fig. $5 \mathrm{C}$ ).

Altogether these results demonstrate that, after LPS stimuli, a deficient Nox 2 activity results in increased levels of reduced TRX-1 into the nucleus leading to a NF- $\kappa$ B over activation.

Nox2 limits the severity of sepsis through TRX-1/NF- $\kappa$ B signaling pathway. Sepsis is the major cause of mortality in critically ill patients. During sepsis, invading pathogens trigger a systemic inflammatory response syndrome (SIRS), which requires the activation of NF- $\kappa B$ by microbial products, such as LPS ${ }^{26-28}$. It was reasoned that the Nox2/TRX-1/NF- $\kappa B$ intracellular signaling pathway triggered by LPS is implicated in sepsis pathophysiology. ROS-production was evaluated in blood and peritoneal leukocytes from mice deficient in Nox2 $\left(\operatorname{Nox} 2^{-/ y}\right)$ and those wild type (WT) treated with APO. All these mice were submitted to a mouse cecal ligation and puncture (CLP) model of sepsis. Sepsis induced an increased ROS-generation by leukocytes systemically and at the site of infection, which was severely impaired in both Nox $2^{-/ y}$ mice and APO-treated mice (Supplementary Fig. 8A,B). APO treatment or the genetic deficiency of Nox2 increased bacterial load in blood (Fig. 6A) and reduced survival rates after CLP in comparison with WT septic mice (Fig. 6B). The fact that either Nox2 deficient or APO- treated mice presented similar number of leukocytes/neutrophils into the infectious foci (Supplementary Fig. 8C,D), as compared to control mice, reinforces that the increased bacterial load is a consequence of an impaired leukocyte microbicidal ability (Supplementary Fig. 8E). Interestingly, both Nox $2^{-/ y}$ and APO-treated mice submitted to CLP had higher numbers of neutrophils trapped in the lungs as compared to controls (Fig. 6D), which is a hallmark of an overwhelmed SIRS ${ }^{28}$. Next, the role of Nox2 was determined when the mice were under antibiotic therapy (analogous to the clinical management of sepsis ${ }^{26}$ ). Mice received a microbicidal antibiotic (ATB, ertapenem sodium, $30 \mathrm{mg} / \mathrm{kg}$ ), six hours after CLP and 12 hourly thereafter. Although antibiotic treatment reduced bacteremia in APO-treated mice to a level comparable to that in control mice (Fig. 6A), survival rates remained significantly lower in mice with deficient Nox2 activity (Fig. 6C). Consistent with an 
A

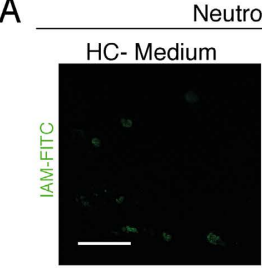

CGD- Medium
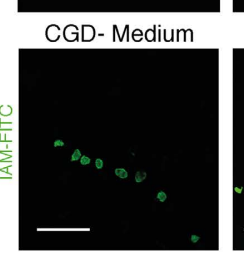

C

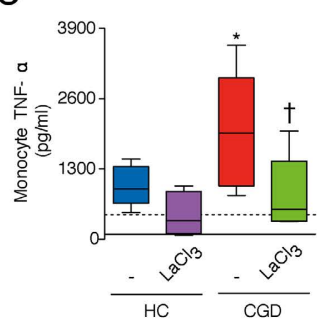

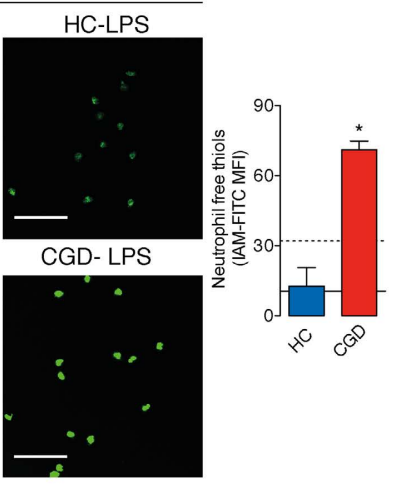

D

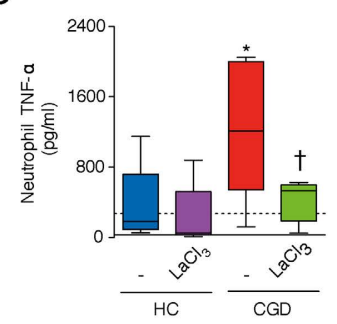

B
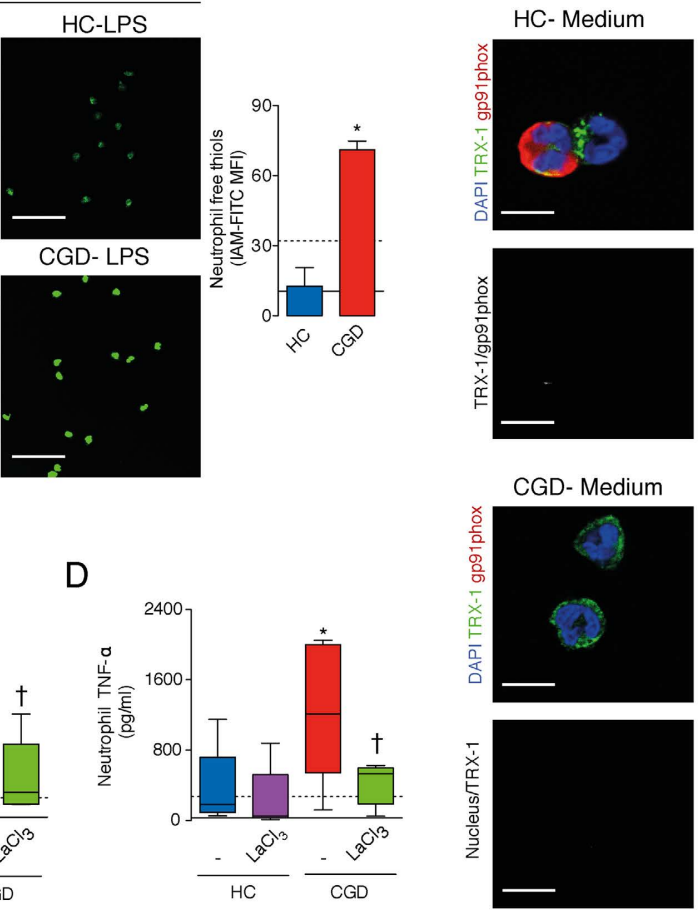
Neutrophils

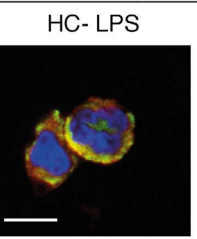
$\mathrm{HC}-\mathrm{LPS}+\mathrm{LaCl}_{3}$
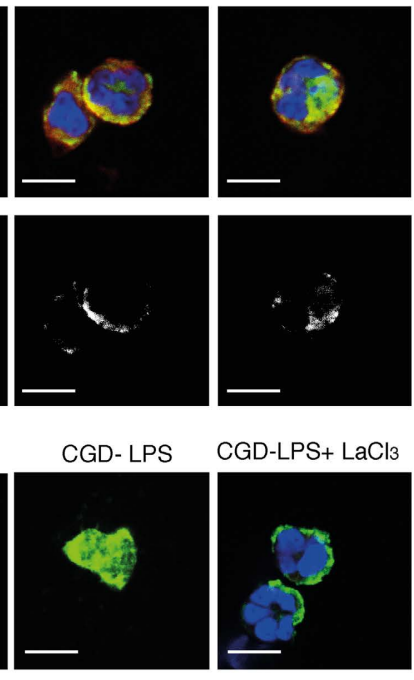

CGD-LPS+ $\mathrm{LaCl}_{3}$
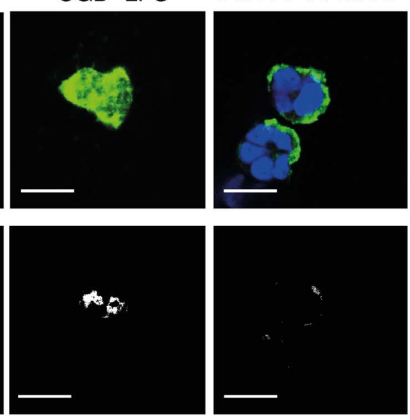

Figure 5. TrxR-1 inhibition prevents aberrant TNF- $\alpha$ production by leukocytes from chronic granulomatous disease patients (CGD) stimulated with LPS. (A-C) Neutrophils from healthy controls $(\mathrm{HC}, \mathrm{n}=5)$ or CGD patients $(\mathrm{n}=5)$ were stimulated with LPS $(10 \mathrm{ng} / \mathrm{ml})$. (A) Staining with IAM-FITC (green), 30 minutes after LPS. Images were obtained by confocal microscopy (63X objective). Scale bars, $50 \mu \mathrm{m}$. The results are expressed as the means fluorescence intensity (MIF) \pm SEM obtained by analyzing 15 cells/subject. (B) Colocalization (white) of TRX-1 (green) and Nox2 (gp91phox, red) in HC cells and nuclear accumulation of TRX-1 (white) in cells of CGD cells, 30 minutes after LPS. Nuclear material was stained with DAPI (blue). Images were obtained by confocal microscopy (63X objective; $5 \mathrm{X}$ magnification). Scale bars, $7.5 \mu \mathrm{m}$. (C,D) TNF- $\alpha$ levels in cultures supernatant (ELISA), 12 hours after LPS. Some cells were treated with lanthanum chloride $\left(\mathrm{LaCl}_{3}, 1 \mu \mathrm{M}\right) 30$ minutes before LPS. Box plots show median, interquartile range, sample minimum and maximum. Black continuous and dashed lines indicate the average values obtained by analysing, respectively, $\mathrm{HC}$ and CGD cells in medium only. ${ }^{\star} P<0.05$ as compared to HC cells stimulated with LPS; ${ }^{\dagger} P<0.05$ as compared to CGD cells stimulated with LPS.

increased SIRS independent of bacterial killing but related to an over activation of NF- $\kappa \mathrm{B}$, APO-treated mice under antibiotic therapy had aggravated neutrophil trapping in the lungs, and increased plasma levels of TNF- $\alpha$, IL-6 (Fig. 6D-F), aspartate aminotransferase (AST) and blood urea nitrogen (i.e. markers of renal dysfunction and liver injury, respectively- Supplementary Fig. 9A,B). In the setting of sepsis undergoing antibiotic therapy, the inhibition of TrxR-1 by either $\mathrm{LaCl}_{3}$ or AUR significantly increased the survival rates of APO-treated mice (Fig. 6G,H). Moreover, both TrxR-1 inhibitors increased the survival rates of WT mice submitted to CLP, even in the absence of antibiotic therapy (Fig. 6I). This strongly implies the Nox2/TRX-1/NF- $\kappa$ B signaling pathway in the pathophysiology of sepsis.

Overall, our results revealed a novel Nox2/TRX-1/NF- $\mathrm{B}$ intracellular signaling pathway (Fig. 7) which contributes to better understanding of the hyperinflammation in CGD patients and also suggests TRX-1 as a novel therapeutic target in sepsis.

\section{Discussion}

It is well established that neutrophil Nox2 is critical for the killing of phagocytized pathogens and its deficiency is associated with increased susceptibility of CGD patients to sepsis and other kinds of infections ${ }^{1}$. Indeed, neutrophils from Nox $2^{-/ y}$ or WT pre-incubated with APO showed a significant deficiency in killing, which might be associated to high bacterial load in blood found in Nox $2^{-/ y}$ and APO-treated mice submitted to CLP. Nevertheless, even after antibiotic treatment and effective control of infection, deficient Nox2 activity resulted in increased systemic inflammatory response and multi-organ dysfunction. Actually, the Nox 2 anti-inflammatory effects were extensively demonstrated in murine models ${ }^{2-5}$ and in CGD patients ${ }^{1,6}$, however the precise intracellular mechanisms mediated by Nox2 have not being elucidated previously. In this study, a Nox2/TRX-1/NF- $\mathrm{B}$ signaling pathway implicated in sepsis and CGD induced-hyperinflammation was identified (Fig. 7).

Although the interaction between the Nox 2 subunit p40phox and TRX-1 was previously established ${ }^{11}$, the real consequences of this association in cell redox homeostasis and intracellular signaling have been neglected. Herein, TRX-1/p40phox interaction was observed preferentially after Nox2 assembly. In fact, p40phox is phosphorylated 
A
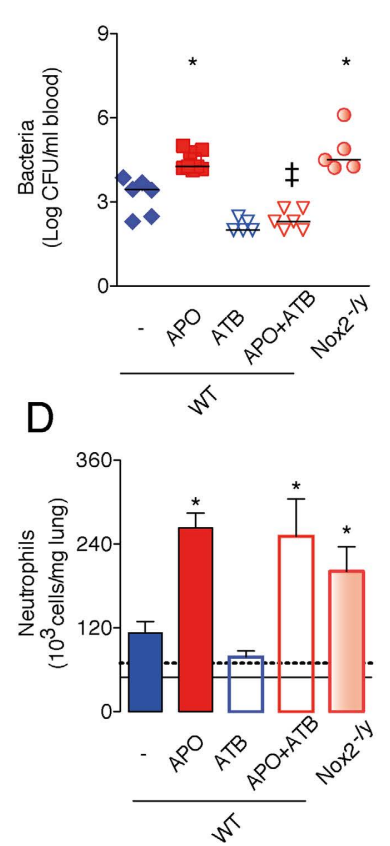

G

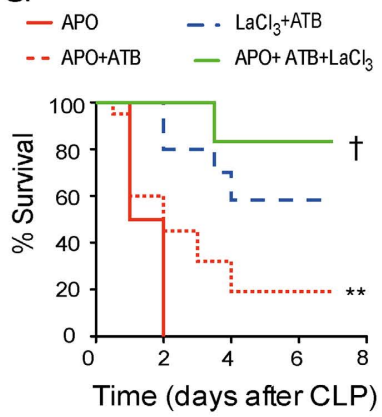

B

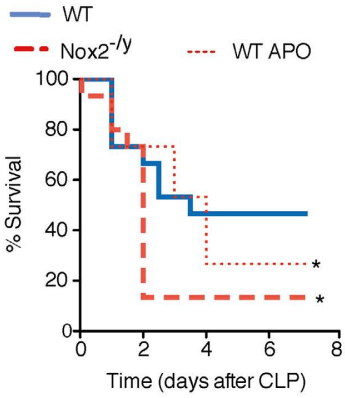

E

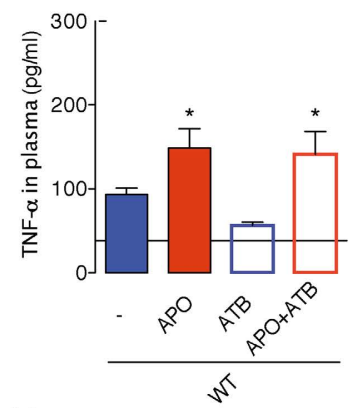

$\mathrm{H}$
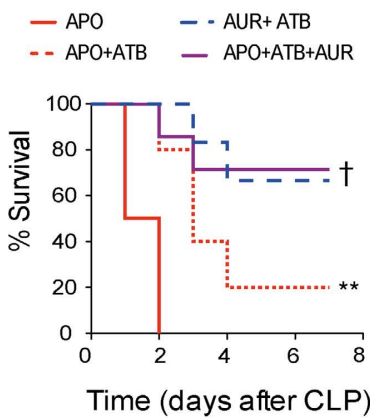

C

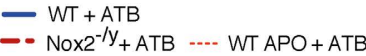

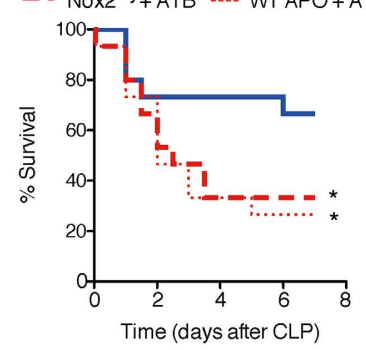

$\mathrm{F}$

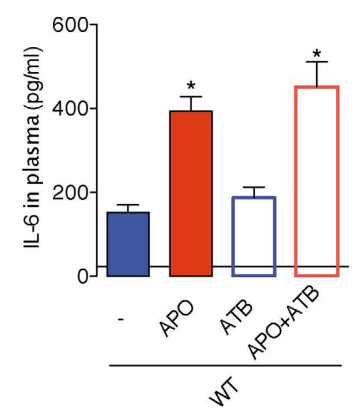

I

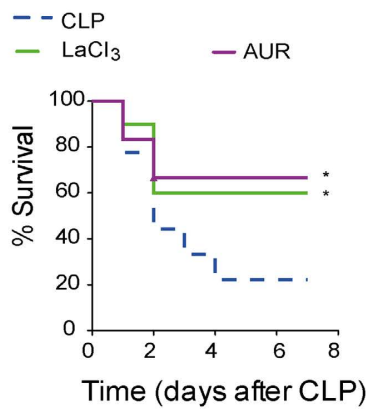

Figure 6. TrxR-1 inhibition enhances sepsis survival of mice treated with APO. Wild type (WT) mice subcutaneously treated with APO $\left(200 \mathrm{mg} / \mathrm{kg}, 30\right.$ minutes before surgery) and Nox $2^{-/ y}$ mice were submitted to cecal ligation and puncture (CLP). Some mice were intraperitonously treated with antibiotic (ATB, ertapenem sodium, $30 \mathrm{mg} / \mathrm{kg}$ ), six hours after surgery and 12 hourly thereafter. (A) Bacterial load in blood, 12 hours after CLP. The graph represents the individual logarithmic values of CFU around median ( $\mathrm{n}=5-7 /$ group). (B,C) Survival rates $(\mathrm{n}=15$ /group). (D-F) Number of neutrophils trapped in lungs, levels of TNF- $\alpha$ and IL-6 in plasma, six hours after ATB treatment and 12 hours after CLP. The results are expressed as the means \pm SEM $(\mathrm{n}=5-7 /$ group$)$. Black continuous and dashed lines in bar graphs indicate the average values obtained by analysing WT and Nox $2^{-/ y}$ sham-operated mice, respectively. (G-I) Mice were treated with $\mathrm{LaCl}_{3}(10 \mathrm{mg} / \mathrm{kg}$, subcutaneously), which was administered six hours after surgery and 12 hourly thereafter; or mice were treated with auranofin (AUR, $2 \mathrm{mg} / \mathrm{kg}$, subcutaneously), which was administered six hours after surgery and 24 hourly thereafter. Survival rates $\left(n=7-10\right.$ /group; $n=7, A U R$ and/or APO treated mice; $n=10, \mathrm{LaCL}_{3}$ and or APO treated mice). ${ }^{\star} P<0.05$ as compared to WT-CLP mice; ${ }^{\dagger} P<0.05$ as compared to APO-CLP mice under antibiotic therapy; ${ }^{\ddagger} P<0.05$ as compared to APO-CLP mice without ATB treatment; ${ }^{\star *} P<0.05$ as compared to $\mathrm{LaCl}_{3}$-CLP or AUR -CLP mice, both under antibiotic therapy.

downstream of TLR4 activation by LPS, which allows its assembly with p67phox and Nox $2^{10}$. It was also verified that TRX-1/p40phox interaction depends on the cysteine residues 32 and 35, that encompass the active redox site of TRX-1. In fact, ROS produced by Nox 2 followed by LPS stimuli directly modified TRX-1 redox state, which regulated cell redox status. On the other hand, cells with deficient Nox 2 activity stimulated with LPS had a reductive stress (increased levels of GSH and other free thiol group ${ }^{20}$ ) and increased levels of TRX-1 in the nucleus.

$\mathrm{NF}-\kappa \mathrm{B}$ is a major transcription factor involved in the synthesis of inflammation-related molecules ${ }^{14}$ and therefore it is a likely target for Nox2-dependent anti-inflammatory effects. We found that the mechanism of increased NF- $\kappa$ B activity in a Nox2-deficient setting was due to a TRX-1 induction of a reductive stress, which was prevented by the oxidizing agent (DTNB). These results are consistent with previous findings that NF- $\kappa B$ binding to DNA is modulated by oxidation/reduction ${ }^{19}$ and that $\mathrm{p} 47$ phox-deficient mice have enhanced NF- $\kappa \mathrm{B}$ binding to DNA in lung extracts after intraperitoneal LPS-treatment ${ }^{5}$. Importantly, the higher levels of reduced 

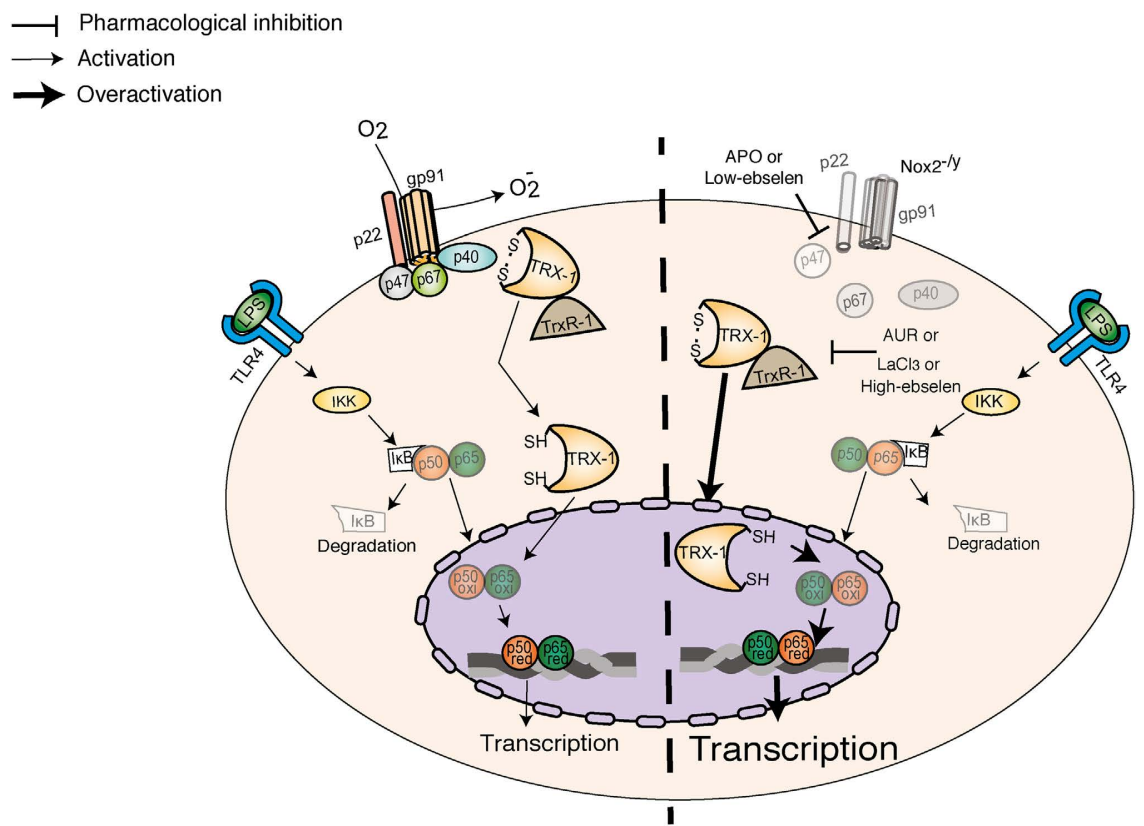

Figure 7. Nox2 regulates NF- $\kappa B$ activation by modifying TRX-1 redox-state. Schematic representation. Left panel: Nox 2 assembly favors TRX-1 interaction with p40phox. Oxidized TRX-1 is excluded from the nucleus by $\mathrm{p} 40$ phox until its reduction by thioredoxin reductase-1 (TrxR-1). The TRX-1 reduction allows its nuclear localization, where it facilitates NF- $\kappa B$ binding to DNA. Right panel: the genetic deficiency (Nox $2^{-/ y}$ ) or pharmacological inhibition of Nox2 (with apocynin, APO; or low-concentration-ebselen) results in reduction of TRX-1 and its nuclear accumulation. In the nucleus, reduced TRX-1 potentiates NF- $\kappa$ B binding to DNA, and consequently, enhances the transcription of inflammatory mediators. TrxR-1 inhibitors, such as lanthanum chloride $\left(\mathrm{LaCl}_{3}\right)$, auranofin (AUR) or high-concentration-ebselen prevent overactivation of NF- $\kappa \mathrm{B}$.

TRX-1 inducing a reductive stress may not only directly modulate NF- $\kappa B$ activity but also alter the redox state of other cysteine-containing proteins, such as ref. 1, which also enhances NF- $\kappa \mathrm{B} / \mathrm{DNA}$ binding $^{5}$. Furthermore, oxidation of TRX-1 (through LPS-induced Nox2 activity or treatment with $\mathrm{H}_{2} \mathrm{O}_{2}$ or with TrxR-1 inhibitors) excluded TRX-1 from the nucleus, which was attributed to an increased binding with p40phox. The TRX-1/ p40phox/Nox2-dependent mechanism is consistent with the emerging theme of Nox-dependent redox signaling, in which oxidase regulatory subunits (e.g. p40phox and p47phox) act as scaffolds that colocalize the activated Nox 2 complex with redox-sensitive signaling targets within a cellular microdomain ${ }^{29}$. The involvement of reduced TRX-1 in NF- $\kappa$ B over activation induced by Nox 2 deficiency was corroborated by results with $\mathrm{LaCl}_{3}$, AUR and high-concentration-ebselen that shifted the redox equilibrium of TRX-1 towards its oxidized state by inhibiting TrxR-1. Indeed, either $\mathrm{LaCl}_{3}$ or AUR prevented NF- $\kappa \mathrm{B}$ over activation in APO-treated RAW264.7 cells. Furthermore, $\mathrm{LaCl}_{3}$ inhibited the exaggerated LPS-induced TNF- $\alpha$ synthesis observed in monocytes and neutrophils of human CGD patients and it also increased the survival rates of APO-treated mice submitted to CLP, providing clear evidence for the in vivo efficacy of targeting the Nox2/TRX-1/NF- $\kappa$ B pathway.

ROS-produced by Nox 2 controlled inflammation and infection in early sepsis. Therefore, Nox 2 is protective. Accordingly, a previous study evaluating septic patients concluded that the severity of the disease was inversely correlated with ROS production by circulating neutrophils ${ }^{30}$. Likewise, a recent meta-analysis involving 2,768 patients observed that the antioxidant, $\mathrm{N}$-acetyl cysteine, did not improve sepsis outcome but was rather associated with cardiovascular instability ${ }^{31}$. Although, we have previously verified that either apocynin treatment or Nox2 deficiency reduces inflammation of the central nervous system, five days after CLP ${ }^{32}$, the beneficial role of Nox2 during sepsis in early phases of the disease cannot be neglected. In the present study we verified the total mortality rates of APO-treated or Nox $2^{-1-}$ mice were higher as compared to WT mice. In fact, the higher systemic inflammation in early phases of sepsis is essential to determine long-term survival ${ }^{26}$. We have also verified APO-treated or Nox $2^{-1-}$ mice present a higher inflammatory response as compared to WT, 12 hours post-CLP, which resulted in higher multi-organ dysfunction and death. Additionally, the transcription of TLR4 and TNF- $\alpha$ was upregulated in neutrophils and peritoneal macrophages under Nox2-deficient conditions, which may explain the increased neutrophil sequestration in the lungs of APO-treated and Nox $2^{-/ y}$ mice subjected to CLP ${ }^{28}$.

Recently, some studies have shown an association between Nox2 deficiency and an altered $\mathrm{Ca}^{2+}$ influx $^{33-35}$. In this regard, $\mathrm{LaCl}_{3}$, in addition to its role inhibiting TrxR-1, is also able to block $\mathrm{Ca}^{2+}$ channels ${ }^{23}$ and to impair the binding of LPS to monocytes ${ }^{36}$. Since, it was verified that $\mathrm{LaCl}_{3}$ increased survival rates of APO-treated mice submitted to CLP, we cannot exclude the additional protective effect of in vivo $\mathrm{Ca}^{2+}$ blockade in endothelial cells or platelets, which could prevent vascular dysfunction in sepsis. Nevertheless, the potential of $\mathrm{LaCl}_{3}$ to prevent the reductive stress in the setting of deficient Nox2 activity was confirmed through analyses of results obtained from TRX-1-reductase activity assay and the capacity of $\mathrm{LaCl}_{3}$ to exclude TRX-1 from the nucleus of CGD neutrophils treated with LPS. These effects of $\mathrm{LaCl}_{3}$ were independent of LPS cell binding or the altered $\mathrm{Ca}^{2+}$ influx. Moreover, 
the ability of $\mathrm{LaCl}_{3}$ in preventing the APO-induced NF- $\kappa$ B over activation and the CLP-induced mortality were similar to those observed with auranofin (AUR), which is a gold standard TrxR-1 inhibitor devoid of $\mathrm{Ca}^{2+}$ related effects $^{22}$.

It was previously demonstrated that intermediates of APO oxidation are able to scavenge the GSH${ }^{37}$. Therefore, these APO-derived compounds could prevent the reductive stress resultant from the failure of Nox 2 activation in the cells under LPS stimulation. However, this last hypothesis was not observed in the present study. Actually, APO-treatment did not prevent the reductive stress (enhanced IAM-FITC staining) of Nox2 deficient macrophages stimulated with LPS. Thus, our results regarding NF- $\kappa$ B over activation after APO-treatment are dependent on Nox2 inhibition and are not due to a direct effect of APO-intermediates on cellular redox status.

Altogether, the current results identify a hitherto unrecognized Nox2-regulated TRX-1 pathway that promotes the control of NF- $\mathrm{KB}$-dependent transcription of inflammatory mediators (Fig. 7). These findings may be especially relevant in CGD patients, and allow us to suggest TrxR-1 inhibitors as novels therapeutic approaches to target hyperinflammation. Furthermore, we have verified that TrxR-1 inhibitors, either $\mathrm{LaCl}_{3}$ or AUR, increase sepsis survival. Therefore, they could also be potential drugs to treat septic patients in future.

\section{Methods}

Animals. Experiments were performed in six-week-old adult male mice of the C57BL/ 6 strain. Nox $2^{-/ y}$ mice were obtained from Jackson Laboratories and bred locally. CLP and sham procedures were performed under intraperitoneal ketamine/xylazine anesthesia as previously described ${ }^{38}$. Animal care, handling and surgical procedures were in accordance with The Ethical Principle in Animal Research adopted by Brazilian College of Animal Experimentation (COBEA). All studies using animals were approved by The Ethical Commission of Ethics in Animal Research (CETEA) of Ribeirao Preto Medical School, University of Sao Paulo, Ribeirão Preto, São Paulo State, Brazil (protocols no 032/2011 and 062/2013).

Leukocyte purification. Mouse neutrophils were purified from bone marrow (BM) as described previously $^{38}$. Peritoneal macrophages were harvested by instilling $1.5 \mathrm{ml}$ PBS containing $1 \mathrm{mM}$ EDTA into the abdomen and subsequent adherence on acrylic culture plates. Human neutrophils and monocytes were isolated by a standard four-layer Percoll gradient method (45, 54, 63 and 75\%). Erythrocytes were depleted in $\mathrm{NH}_{4} \mathrm{Cl}$ buffer $(0.14 \mathrm{M})$.

Bacterial counts. Peritoneal exudate and blood were collected under sterile conditions, plated on Muller-Hinton agar dishes (Difco Laboratories, USA), and incubated at $37^{\circ} \mathrm{C}$. Colony forming units (CFU) were recorded after 18 hours.

Immunofluorescence. Cells were fixed with $4 \%$ paraformaldehyde and permeabilized with $0.2 \%$ Triton-X. Primary antibodies (Abs) were used at 1:100 to 1:200 dilution. Nucleus were stained with 4,6-diamidino-2-phenylindole (DAPI). To determine the levels of thiol free groups, paraformaldehyde-fixed cells were incubated with $0.75 \mathrm{mM}$ 6-iodoacetamide fluorescein (IAM-FITC, Sigma Aldrich, St. Louis, MO) for 30 minutes. DTT (reducing agent) or DTNB (oxidizing agent) were used as controls. Images were acquired by confocal microscopy (TCS SP5 II, Leica Microsystems). Fluorescencense intensity was quantified by using Image J software (Image Processing and Analysis in Java, Mac OS X 10.8 application, Wayne Rasband, National Institutes of Healthy, USA). The colocalization analysis was performed using the plugin Colocalization highligter available in the same software.

NF- $\kappa$ B activity. Experiments were performed in a RAW264.7 cell line containing an NF- $\kappa$ B promoterluciferase construct (pNF- $\mathrm{B}$-Luc). Luciferase activities in cell lysates were determined by using the Luciferase 1000 assay system (Promega) in a luminometer (GloMax 20/20 Single tube luminometer, Promega).

Immunoblotting, sucrose gradient and immunoprecipitation. Immunoblotting was performed using a standard protocol. The redox state of TRX-1 was determined in native gels without additon of 2 - $\beta$-mercaptoethanol in samples, as described previously ${ }^{17}$. Thiol groups in cell lysates were firstly alkylated with iodoacetic acid $(50 \mathrm{mM})$ in a $6 \mathrm{M}$ guanidine- $\mathrm{HCl}$ buffer with $0.5 \%$ Triton $\mathrm{X}-100$. For sucrose gradient separation, cell lysates were laid on the top of a four-layer sucrose gradient (10, 20, 40 and 60\%). Samples were centrifuged at $35,000 \mathrm{~g}$ for 18 hours and fractions were submitted to polyacrilamide gel electrophoresis (SDS-PAGE). A mix of proteins from $12-200 \mathrm{kDa}$ (Gel filtration molecular weight markers, Sigma-Aldrich) was used as control in sucrose grandient centrifugation, with the separated proteins stained with Coomassie Blue. For immunoprecipitation analyses, cell lysates were incubated with anti-TRX-1, protein A/G and agarose immunoprecipitation reagent (Santa Cruz), green fluorescent protein-(GFP)-Trap A (Chromo Tek GmbH, Munich, Germany) or antimyc immunoprecipitation kit (Sigma-Aldrich, St. Louis, USA) as appropriate. Protein band densitometry was quantified by using Image J software.

Reductase activity. The insulin reduction assay was used to estimate TRX-1 mediated reductase activity ${ }^{16}$. The precipitation of the insulin $\beta$-chain was initiated by adding $1 \mathrm{mM}$ DTT in a $100 \mu \mathrm{M}$ sodium phosphate buffer ( $\mathrm{pH}$ 6.5) containing $2 \mathrm{mM}$ ethylenediamine-tetraacetic-acid (EDTA) and insulin (Lanthus ${ }^{\circledR}$, insulin glargine rDNA origen- final concentration of $1 \mathrm{U} / \mathrm{ml}$ ) to cell lysates. The analysis was followed at $650 \mathrm{~nm}$ in a microplate reader coupled to a spectrophotometer (SpectraMax M5, Molecular Devices, Sunnyvale, CA, USA) and corrected by total protein levels determined with Bradford reagent (Sigma-Aldrich).

EMSA. EMSA was performed as described previously ${ }^{39}$. NF- $\kappa B$ double-stranded consensus oligonucleotide (5'-AGTTGAGGGGACTTTCCCAGGC-3') was end-labeled with $\gamma-{ }^{32} \mathrm{P}$-ATP and unincorporated nucleotides 
removed by using a Sephadex G-25 spin column. Purified ${ }^{32} \mathrm{P}$-labeled probe was incubated with $5 \mu \mathrm{g}$ nuclear extract in a buffered solution $(50 \mathrm{mM} \mathrm{NaCl}, 0.2 \mathrm{mM}$ EDTA, $4 \%$ glycerol, $10 \mathrm{mM}$ Tris- $\mathrm{HCl}$ ) containing $0.05 \mu \mathrm{g}$ poly $(\mathrm{dI}-\mathrm{dC})$ for 30 minutes at room temperature. DNA-protein complexes were separated through a $6 \%$ non-denaturing polyacrylamide gel. Gels were analyzed by autoradiography. For competition experiments, NF- $\kappa B$ unlabeled double-stranded consensus oligonucleotide was included in two-fold molar excess over the amount of ${ }^{32} \mathrm{P}-\mathrm{NF}-\kappa \mathrm{B}$ probe. Anti-p65 or anti-p50 were added in some nuclear extracts before electrophoresis.

CGD patients. Peripheral blood samples were collected from five patients with CGD (Supplementary Table S1) and five healthy individuals (controls) with a written informed consent. Studies using human samples were conducted in accordance with The Ethics Committee on Human Research adopted by The Brazilian Ministry of Healthy and were approved by The Ethical guidelines of Clinics Hospital of Ribeirao Preto Medical School, University of Sao Paulo, Ribeirão Preto, São Paulo State, Brazil (protocol no. 325.272).

Other assays. Cytokine/chemokine levels were quantified by using enzymatic-linked immunosorbent assay (ELISA) with antibodies from R\&D Systems. Lung myeloperoxidase activity was measured as an index of neutrophil sequestration ${ }^{40}$. Plasma concentrations of aspartate-aminotransferase (AST) and urea were measured by using commercial kits (Labtest, Brazil; Bioclin, Brazil). Reduced glutathione (GSH) assays were performed using the GSH-Glo assay kit (Promega) as described by the manufacturer. Cell viability was determined by using ApoScreen ${ }^{\mathrm{TM}}$ Annexin V apoptosis Kit (Southern Biotecnology, USA) according to the manufacturer's instructions.

Statistics. Analyses were performed using SAS software v9.0 (SAS Institute Inc., USA). The log-rank (Mantel-Cox) test was used to evaluate the survival rates. The Mann-Whitney test was used to assess variables with two experimental groups and the Kruskal-Wallis test followed by Dunn's post-hoc correction was used for analyses involving more than two groups.

For more details regarding methods, please see Supplementary Information available online.

\section{References}

1. Dinauer, M. C. \& Orkin, S. H. Chronic granulomatous disease. Annu Rev Med. 43, 117-124 (1992).

2. Pollock, J. D. et al. Mouse model of X-linked chronic granulomatous disease, an inherited defect in phagocyte superoxide production. Nat Genet. 9, 202-209 (1995).

3. Deffert, C. et al. Hyperinflammation of chronic granulomatous disease is abolished by Nox 2 reconstitution in macrophages and dendritic cells. J Pathol. 228, 341-350 (2012).

4. Whitmore, L. C. et al. NOX2 protects against prolonged inflammation, lung injury, and mortality following systemic insults. J Innate Immun. 5, 565-580 (2013).

5. Han, W. et al. NADPH oxidase limits lipopolysaccharide-induced lung inflammation and injury in mice through reductionoxidation regulation of NF-kappaB activity. J Immunol. 190, 4786-4794 (2013).

6. Brown, K. L. et al. ROS-deficient monocytes have aberrant gene expression that correlates with inflammatory disorders of chronic granulomatous disease. Clin Immunol. 129, 90-102 (2008).

7. El-Benna, J., Dang, P. M. \& Gougerot-Pocidalo, M. A. Priming of the neutrophil NADPH oxidase activation: role of p47phox phosphorylation and NOX2 mobilization to the plasma membrane. Semin Immunopathol. 30, 279-289 (2008).

8. Ximenes, V. F., Kanegae, M. P., Rissato, S. R. \& Galhiane, M. S. The oxidation of apocynin catalyzed by myeloperoxidase: Proposal for NADPH oxidase inhibition. Arch. Biochem. Biophys. 457, 134-141 (2007).

9. Mora-Pale, M., Kwon, S. J., Linhardt, R. J. \& Dordick, J. S. Trimer hydroxylated quinone derived from apocynin targets cysteine residues of p47phox preventing the activation of human vascular NADPH oxidase. Free Radic Biol Med. 52, 962-969 (2012).

10. Ellson, C. et al. PtdIns3P binding to the PX domain of $\mathrm{p} 40$ phox is a physiological signal in NADPH oxidase activation. EMBO J. 25, 4468-4478 (2006).

11. Nishiyama, A. et al. Demonstration of the interaction of thioredoxin with p40phox, a phagocyte oxidase component, using a yeast two-hybrid system. Immunol Lett. 68, 155-159 (1999).

12. Lu, J. \& Holmgren, A. The thioredoxin antioxidante system. Free Radic Biol Med. 66, 75-87 (2014).

13. Matthews, J. R. et al. Thioredoxin regulates the DNA binding activity of NF-kappa B by reduction of a disulphide bond involving cysteine 62. Nucleic Acids Res. 20, 3821-3830 (1992).

14. Kawai, T. \& Akira, S. Signaling to NF- $\kappa B$ by Toll-like receptors. Trends Mol Med. 13, 460-469 (2007).

15. Hansen, R. E. \& Winther, J. R. An introduction to methods for analyzing thiols and disulfides: Reactions, reagents, and practical considerations. Anal Biochem. 394, 147-158 (2009).

16. Du, Y. et al. Thioredoxin-1 is inactivated due to oxidation induced by peroxiredoxin under oxidative stress and reactivated by the glutaredoxin system. J. Biol. Chem. 288, 32241-32247 (2013).

17. Go, Y. M. \& Jones, D. P. Thioredoxin redox western analysis. In: Curr Protoc Toxicol. (ed. Maines, M. H.). Ch. 17, unit 17.12 (John Wiley and Sons, 2009).

18. Bjornstedt, M., Kumar, S. \& Holmgren, A. Selenite and selenodiglutathione. Reactions with thioredoxin systems. Methods Enzymol. 252, 209-219 (1995).

19. Toledano, M. B. \& Leonard, W. J. Modulation of transcription factor NF-kappa B binding activity by oxidation-reduction in vitro. Proc Natl Acad Sci USA 88, 4328-4332 (1991).

20. Narasimhan, M. \& Rajasekaran, N. Reductive potential- A savior turns stressor in protein aggregation cardiomyopathy. Biochimica et Biophysica Acta. 1852, 53-60 (2015)

21. Lee, S. J. et al. The IKK-neutralizing compound Bay11 kills supereffector CD8 T cells by altering caspase-dependent activationinduced cell death. J Leukoc Biol. 85, 175-185 (2009).

22. Becker, K., Gromer, S., Schiremer, R. H. \& Muller, S. Thioredoxin reductase as a pathophysiological fator and drug target. Eur J Biochem. 267, 6118-6125 (2000).

23. Citta, A. et al. Inhibition of thioredoxin reductase by lanthanum chloride. J Inorg Biochem. 117, 18-24 (2012).

24. Smith, S. M. et al. Ebselen and congeners inhibit NADPH oxidase 2-dependent superoxide generation by interrupting the binding of regulatory subunits. Chemistry \& Biology. 19, 752-763 (2012).

25. Zhao, R., Masayasu, H. \& Holmgren, A. Ebselen: a substrate for human thioredoxin reductase strongly stimulating its hydroperoxide reductase activity and a superfast thioredoxin oxidant. Proceedings of the National Academy of Sciences of the United States of America. 99, 8579-8584 (2002).

26. Angus, D. C. \& Van Der Poll, T. Severe sepsis and septic shock. N Engl J Med. 369, 840-851 (2013).

27. Böhrer, H. et al. Role of NFkB in the mortality of sepsis. J Clin Invest 100, 972-985 (1997). 
28. Souto, F. O. et al. Essential role of CCR2 in neutrophil tissue infiltration and multiple organ dysfunction in sepsis. Am J Respir Crit Care Med. 183, 234-242 (2011).

29. Oakley, F. D., Abbott, D., Li, Q. \& Engelhardt, J. F. Signaling components of redox active endosomes: the redoxosomes. Antioxid Redox Signal. 11, 1313-1333 (2009).

30. Martins, P. S. et al. Expression of cell surface receptors and oxidative metabolism modulation in the clinical continuum of sepsis. Crit Care. 12, R25 (2008).

31. Szakmany, T., Hauser, B. \& Radermacher, P. N-Acetylcysteine for sepsis and systemic inflammatory response in adults. Cochrane Database Syst Rev. 9, CD006616 (2012).

32. Hernandes, M. S. et al. The role of Nox2-derived ROS in the development of cognitive impairment after sepsis. J Neuroinflammation. 27, 11-36 (2014).

33. Weissmann, N. et al. Activation of TRPC6 channels is essential for lung ischaemia-reperfusion induced oedema in mice. Nature communications. 3, 1-10 (2012).

34. Gandhirajan, R. K. et al. Blockade of NOX2 and STIM1 signaling limits lipopolysaccharide-induced vascular inflammation. The Journal of clinical investigation. 123, 887-902 (2013).

35. Kim, K. et al. Nox2 is critical for heterotypic neutrophil-platelet interactions during vascular inflammation. Blood. 126, 1952-1964 (2015).

36. Wang, Y. et al. Lanthanum inhibited the binding of LPS with monocyte and CD14 expression upregulation. Cell \& Molecular Immunology. 1, 392-394 (2004).

37. Kanegae, M. P. P., Fonseca, L. M., Brunetti, I. L., Silva, S. O. \& Ximenes, V. F. The reactivity of ortho-methoxy-substitutes catechol radicals with sulfhydryl groups: Contribution for the comprehension of the mechanism of inhibiton of NADPH oxidase by apocynin. Biochemical Pharmacology. 74, 457-464 (2007).

38. Alves-Filho, J. C. et al. Regulation of chemokine receptor by Toll-like receptor 2 is critical to neutrophil migration and resistance to polymicrobial sepsis. Proc Natl Acad Sci USA 106, 4018-4023 (2009).

39. Hernandes, M. S. et al. Eye enucleation activates the transcription nuclear factor kappa-B in the rat superior colliculus. Neurosci Lett. 521, 104-108 (2012).

40. Moreno, S. E. et al. Systemic administration of interleukin-2 inhibits inflammatory neutrophil migration: role of nitric oxide. $\mathrm{Br} \mathrm{J}$ Pharmacol. 148, 1060-1066 (2006).

\section{Acknowledgements}

We thank Giuliana Bertozi, Sidney Verissimo, Ana Katia dos Santos, Sergio Rosa, Ieda Regina dos Santos, Denise Ferraz, Adilson Alves, Xiaohong Zhang, Elizabete Rosa Milani and Diva Amabile for technical assistance; and Paula Barbim, Fabricio Oliveira Souto, Fabiane Sônego, Matteo Beretta, Rafael França and Alison Brewer for discussions concerning methods. Dario Zamboni provided the RAW264.7 cell line bearing pNF- $\kappa B-L u c$. We thank Caio Abner for helping Silvia C. Trevelin in drawing the scheme in Figure 7. We acknowledge financial support from Sao Paulo Research Foundation (FAPESP), Conselho Nacional de Pesquisa e Desenvolvimento Tecnológico (CNPq), Coordenação de Aperfeiçoamento de Pessoal de Nível Superior (CAPES), the European Society of Cardiology (ESC), and the British Heart Foundation (BHF), and the Department of Health via a National Institute for Health Research (NIHR) Biomedical Research Centre award to Guy's \& St Thomas' NHS Foundation Trust in partnership with King's College London and King's College Hospital NHS Foundation Trust. This work was also supported by grants from the European Union Seventh Framework Programme [FP7-20072013] under grant agreement no HEALTH-F4-2011-281608 (TIMER), from FAPESP under grant agreements no 2009/54764-6 (Projeto Temático), 2011/19670-0 (Projeto Temático), 2013/03520-5 (LRL grant), 2013/ 07937-8 (Redoxoma), 2013/08216-2 (Center for Research in Inflammatory Disease), 2011/03293-3 and 2012/24677-7 (S.C.T fellowship) and from the University of Sao Paulo NAP-DIN under grant agreement no 11.1.21625.01.

\section{Author Contributions}

S.C.T., L.R.L., A.M.S. and F.Q.C. conceived the study, participated in experimental design, interpreted the data and drafted the manuscript. S.C.T., R.G.F., M.Z., R.L.S., A.C. and L.L. carried out experimental assays. C.S., R.C., F.R.M.L., J.C.A.F., T.M.C., A.C., C.X.S., P.R.J. and A.I. participated in experimental design. P.R.J. and M.C.C. carried out patients' inclusion. A.I., R.C., F.M.R.L., A.C., C.X.S., J.C.A.F., J.S.H. and T.M.C. contributed to data interpretation. J.S.H. contributed for drafting the manuscript. All authors read the manuscript and approved submission in its present form.

\section{Additional Information \\ Supplementary information accompanies this paper at http://www.nature.com/srep}

Competing financial interests: The authors declare no competing financial interests.

How to cite this article: Trevelin, S. C. et al. Apocynin and Nox2 regulate NF- $\kappa$ B by modifying thioredoxin-1 redox-state. Sci. Rep. 6, 34581; doi: 10.1038/srep34581 (2016).

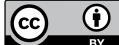

This work is licensed under a Creative Commons Attribution 4.0 International License. The images or other third party material in this article are included in the article's Creative Commons license, unless indicated otherwise in the credit line; if the material is not included under the Creative Commons license, users will need to obtain permission from the license holder to reproduce the material. To view a copy of this license, visit http://creativecommons.org/licenses/by/4.0/

(C) The Author(s) 2016 


\section{Galectin-3 impair neutrophil migration in severe polymicrobial sepsis}

Raphael G. Ferreira1, Daniele C.B. Nascimento ${ }^{1}$, Alexandre Kanashiroㄹ, Paulo Henrique de Melo1,2, Douglas da Silva Prado1, Vanessa de Fátima Borges ${ }^{1}$, Lilian Rodrigues Cataldi ${ }^{3}$, Marcelo Dias Baruffi ${ }^{3}$, Fernando de Queiróz Cunha ${ }^{1,2}$, José Carlos Alves-Filho',

${ }^{1}$ Pharmacology Department (Ribeirão Preto Medical School, University of São Paulo);

²Basic and Applied Immunology Program (Ribeirão Preto Medical School, University of São Paulo);

${ }^{3}$ Department of Clinical Analysis, Toxicological and Bromatological (School of Pharmaceutical Sciences of Ribeirão Preto, University of São Paulo).

Corresponding Author:

José Carlos Alves-Filho, Ph.D.

Department of Pharmacology, Ribeirão Preto Medical School

University of São Paulo

Av. Bandeirantes 3900

14049-900 Ribeirão Preto, SP, Brazil

E-mail: jcafilho@usp.br

Phone: $55-16-3315-3287$ 


\begin{abstract}
Sepsis is an overwhelming systemic inflammation resulting from an uncontrolled host reaction to infection that causes extensive tissue damage, organs dysfunction and eventually death. Growing body of evidence indicate that host endogenous molecules released in response to tissue damage may worsen the outcomes of sepsis. Here we show that galectin-3, a molecule that display several immune modulatory activities, plays a major role in the sepsis progression. We demonstrated that septic shock patients showed higher levels of galectin-3 than patients with sepsis or healthy controls. Moreover, we found a positive correlation between blood serum galectin-3 concentration and severity of sepsis. In line, mice underwent lethal polymicrobial sepsis, presented higher blood serum galectin-3 concentration than naïve counterparts. Mice deficient in Galectin-3 (Gal-3 KO) were more resistant to lethal sepsis and showed reduced bacterial load in infectious focus, blood, and lung. Consequently, gal-3 KO mice presented a reduction in damage markers in different tissues. We found increased galectin-3 bound in blood neutrophils surface after CLP. Moreover, there was higher neutrophils number in peritoneal cavity of mice underwent lethal sepsis. Finally, lacks of galectin-3 improve leukocyte rolling and adhesion to mesenteric venules, implying that Galectin-3 released during sepsis impair neutrophils migration to infectious focus. Our data suggests that targeting galectin-3 may be a potentially effective treatment for septic patients
\end{abstract}

Key words: sepsis, galectin-3, neutrophil. 


\section{Introduction}

Sepsis is an overwhelming systemic inflammation resulting from an uncontrolled host reaction to infection that causes extensive tissue damage, organs dysfunction and eventually death (Cohen et al., 2015). Despite extensive research in this field, the current treatments for septic patients are antibiotics and supportive care (Deutschman et al., 2014). A major hallmark of sepsis is the overwhelming systemic inflammation that is triggered by bacterial products (Alves-Filho et al., 2006; Alves-Filho et al., 2009). However, there is now growing body of evidence that host endogenous molecules released in response to tissue damage, called alarmins, also contribute to the overt inflammatory response during sepsis. Therefore, the identification of alarmins and their pathophysiological actions may provide a new target for the development of therapeutic agents able to improve sepsis outcome.

Galectin-3 (Gal-3) is a member of the galectin family widely expressed in mammalian tissues that display several immune modulatory activities (Rabinovich et al., 2009). Gal-3 can be released either passively from dead cells or through active secretion in response to inflammatory stimuli (Henderson et al., 2009). Increased concentration of Gal-3 was detected in the blood of septic patients, which were associated with more severity and poor prognosis for sepsis (ten Oever et al., 2013). However, the exact functions of Gal-3 in sepsis have not been clear investigated. In the present study, using the wellestablished cecal ligation and puncture (CLP) model of sepsis, we investigated the role of Gal-3 on sepsis outcome. 


\section{Materials and methods}

\subsection{Animals}

For this study, we used eight-week-old male C57BL/6 WT (Wild Type) mice or Galectin-3 gene-deficient (Gal-3 KO) mice, weighing 20 to $25 \mathrm{~g}$. WT mice were housed in the Department of Pharmacology of the Ribeirão Preto Medical School at the University of São Paulo. Gal-3 KO mice were housed in the Department of Clinical Analysis, Toxicological and Bromatological of the School of Pharmaceutical Sciences of Ribeirão Preto at the University of São Paulo. All mice were breed in temperature-controlled rooms $\left(22-\mathrm{C}^{\circ} 25-\mathrm{C}^{\circ}\right)$, with access to water and food ad libitum. We performed all experiments in accordance with the guidelines of the Animal Welfare Committee of the Ribeirão Preto Medical School, University of São Paulo, Brazil, protocol number 098/2012.

\subsection{Sepsis model}

Lethal sepsis was induced using the cecal ligation and puncture (CLP) model as previously described by Hubbard et al. (2005). In brief, mice were anesthetized with ketamine $(100 \mathrm{mg} / \mathrm{kg})$ and xylazine $(10 \mathrm{mg} / \mathrm{kg})$ diluted in phosphatebuffered saline (PBS) by the intraperitoneal administration. After midline laparotomy, cecum was exposed and ligated at the level of ileocecal valve without causing intestinal obstruction. In sequence, a puncture was made through the cecum using an 18 gauge needle to induce a severe sepsis (SCLP). After surgical process, mice received a subcutaneous injection of saline 
$(1 \mathrm{ml})$ and were placed in a heated place until complete recovery from anesthesia.

\subsection{Survival rates}

Survival rate of mice was determined every $12 \mathrm{~h}$ thereafter up to day 7 after CLP induction.

\subsection{Determination of neutrophil influx into the peritoneal cavity}

We performed the neutrophil influx experiment as described previously (AlvesFilho et al., 2006). In brief, mice underwent CLP were anesthetized with ketamine $(100 \mathrm{mg} / \mathrm{kg})$ and xylazine $(10 \mathrm{mg} / \mathrm{kg})$ diluted in phosphate-buffered saline (PBS), $6 \mathrm{~h}$ after surgery. Immediately, $2 \mathrm{ml}$ of Ethylenediaminetetraacetic acid (EDTA) solution (0.04\%) was injected into peritoneal cavity and peritoneal fluids collected. A Coulter AcT Diff analyzer (Beckman Coulter) was used to perform total cells counts. Differential cell counts were performed on Cytospin slides stained with Panótico Rápido LB dye (Laborclin, Brazil). The results were expressed as the mean number of neutrophils \pm SEM per cavity.

\subsection{Determination of leukocyte rolling and adhesion}

We performed Intravital Microscopy of Leukocytes to Assess Rolling and Adhesion to the mesenteric vessels as described previously (Alves-Filho et al., 2009). In brief, septic mice were anesthetized with ketamine (100 mg/kg) and xylazine $(10 \mathrm{mg} / \mathrm{kg})$ diluted in phosphate-buffered saline (PBS) by subcutaneous injection. The animals were maintained on a thermostatically controlled board at $37^{\circ} \mathrm{C}$ and the mesenteric tissue was withdrawn for 
microscopic examination. Images were recorded on a video recorder with a long distance objective (x 20). Mesenteric vessels selected for study corresponded to postcapillary venules, with average diameter of $11 \mu \mathrm{m}$. Rolling leukocytes were defined as those white blood cells that moved at a lower velocity than erythrocytes in the same stream during 5-min intervals. Adherent leukocytes were considered as those white blood cells that remained stationary to the venular endothelium at least for 60 seconds of observation and were expressed as the number per $100 \mu \mathrm{m}^{2}$ of venule. All analyses were performed $3 \mathrm{hrs}$ after CLP.

\subsection{Determination of bacterial counts in the peritoneal exudate, blood and} lung

Determination of bacterial count was performed as previously described (Nascimento et al., 2010; Freitas et al., 2011). In brief, mice underwent lethal sepsis were anesthetized with ketamine $(100 \mathrm{mg} / \mathrm{kg})$ and xylazine $(10 \mathrm{mg} / \mathrm{kg})$ diluted in phosphate-buffered saline (PBS) $6 \mathrm{~h}, 12 \mathrm{~h}$ and $24 \mathrm{~h}$ after surgery. Serially diluted peritoneal washing exudate, blood and lung homogenate samples were harvested and $10 \mu$ plated on Muller-Hinton agar dishes (Difco Laboratories). The samples were incubated at $37^{\circ} \mathrm{C}$ for $24 \mathrm{~h}$ and bacterial load determined as colony-forming units per milliliter (CFU/ml).

\subsection{Multiple organ dysfunction measurement}

Biochemical parameters were measured as markers of multiple organ injury or dysfunction in the serum of septic mice as previously described (Freitas et al., 2011). In brief, mice underwent lethal sepsis were anesthetized with ketamine 
(100 mg/kg) and xylazine (10 mg/kg) diluted in phosphate-buffered saline (PBS) by the intraperitoneal administration. Blood serum was collected $6 \mathrm{~h}$ after CLP and cardiac lesion was assessed by increased CK-MB concentration. Moreover, $24 \mathrm{~h}$ after CLP liver and Kidney injury were assessed by increased concentration of alanine aminotransferase $(\mathrm{ALT})$ and Blood urea nitrogen (BUN), respectively. Measurement of biochemical parameters was done using a commercial kit from Labtest (Brazil), according to the manufacture's instructions. The data are presented as units per liter for CK-MB, as units per milliliter for ALT and milligrams per deciliter for BUN.

\subsection{Determination of lung tissue myeloperoxidase activity}

Myeloperoxidase activity test is a quantitative measurement of neutrophil sequestration in lung used as markers of lung injury in systemic inflammatory diseases. In brief, mice underwent lethal sepsis were killed in a CO2 chamber 6 $\mathrm{h}$ after surgery. Lung homogenate was assayed as previously described (AlvesFilho et al., 2010).

\subsection{Galectin-3 levels determination}

We assessed galectin-3 concentration in blood serum of human or mice. Peripheral blood of septic patients was collected immediately after sepsis diagnosis. Peripheral blood of mice was collect $6 \mathrm{~h}$ after lethal sepsis induction. Measurements of galectin-3 was done by enzyme-linked immunosorbent assay (ELISA) using a kit from R\&D Systems according to the manufacturer's instructions. 


\subsection{Patients}

For evaluate the role of galectin-3 in the progression of sepsis we enrolled eleven adult patients admitted to the Emergency Department of the Ribeirão Preto Medical School between October 2014 and January 2015. Patients were classified as having sepsis or septic shock, according to the new recommendation defined by The Third International Consensus Definitions for Sepsis and Septic Shock (Abraham, 2016; Shankar-Hari et al., 2016). Moreover, eight healthy volunteers were also included in the study (Supplementary table 1-2). All patients enrolled fulfilled the criteria defined by the 2001 International Sepsis Definitions Conference (Levy et al., 2003). Peripheral blood samples were collected from all patients immediately after sepsis diagnosis. Informed written consent from all participants was obtained. The study was approved by the Human Subjects Institutional Committee of the Ribeirão Preto Medical School, Brazil (Licence number: 30459114.6.0000.5440).

\subsection{Statistical analysis}

Bacterial load are presented as the median of $\log \mathrm{CFU} / \mathrm{ml}$ and data analyzed with student's t test. The survival rate is expressed as the percentage (\%) of live mice and the Chi-square test was used to determine differences between groups. For the other experiments, the data are reported as the means \pm SEM. The differences between responses were evaluated by one-way ANOVA followed by Bonferroni's multiple comparison tests. The number of animals used 
in each experiment is described in figure legend. $\mathrm{P}<0.05$ was considered statistically significant.

\section{Results}

\subsection{Galectin-3 concentration in blood is elevated in septic shock patients} In order to evaluate whether galectin-3 plays a role in the outcome of sepsis, we firstly evaluated the concentration of galectin-3 in blood serum of patients admitted to the Emergency Department of the School of Medicine of Ribeirão Preto with sepsis or septic shock. We found higher galectin-3 concentration in blood serum of patient with septic shock in relation to healthy donors or patients with sepsis. Moreover, there was not difference in galectin-3 levels between patients with sepsis and healthy donor. To confirm the relation between severity of sepsis and galectin-3 levels, we used a bedside clinical score test termed Sequential [Sepsis-related] Organ Failure Assessment (SOFA). Since, a high SOFA score is correlated with organ dysfunction and death. We found a significant correlation between blood serum galectin-3 level and severity of sepsis. These data support the hypothesis that galectin-3 is associated with poor prognostic during sepsis.

\subsection{Galectin-3 deficiency improves polymicrobial sepsis survival}

The results obtained using samples from septic patients prompt us to deeply investigate the role of galectin-3 during sepsis. We used the cecal ligation and puncture (CLP) procedure, which is considered one of the most clinically relevant model of sepsis (Dejager et al., 2011). First, wild type (WT) mice were subjected to lethal sepsis by CLP and serum was collected $6 \mathrm{~h}$ after for 
evaluate galecti-3 level. As we found in septic shock patients, there is an increase in galectin-3 level in serum of septic mice compared with naïve (Figure 2 A). To confirm the deleterious role of galectein-3 in sepsis, survival rate of WT or Galectin-3 knockout (Gal-3 KO) mice underwent lethal sepsis was monitored. As shown in Figure 2 B, at day 3 after CLP, $100 \%$ of WT mice were dead compared with almost $30 \%$ of survival in Gal-3 KO mice. This protection was sustained throughout the observation period.

\subsection{Galectin-3 deficient mice showed improved bacterial clearance}

In order to understand how galectin-3 affects sepsis outcome, we evaluated the ability of Gal-3 KO mice to control the bacterial infection during CLP. For this purpose, we determined the bacterial load in the peritoneal exudate and in blood 6, 12 and $24 \mathrm{~h}$ after lethal sepsis induction. As shown in Figure $3 \mathrm{~A}$ and B, Gal-3 KO mice subjected to CLP had a marked reduction in bacterial loads in peritoneal exudate and in blood compared with WT mice. To address the bacterial dissemination to distant organs, we evaluated the bacterial load in lung of mice $6 \mathrm{~h}$ after lethal sepsis induction. Gal-3 KO mice subjected to CLP showed a marked reduction in bacterial load in lungs compared with WT mice (Figure $3 \mathrm{C}$ ). Taken together, these data indicate that galectin-3 worsens the control of bacterial growth in mice undergoing lethal sepsis.

\subsection{Galecitn-3 is associated with sepsis-induced organ dysfunction development}

To better characterize the detrimental role of galectin-3 in the outcome of sepsis, we next evaluated the myeloperoxidase activity in lung tissue, an assay 
employed to determine neutrophil accumulation in vital organs. As shown in Figure 4 A, Gal-3 KO mice showed a significant decrease in lung myeloperoxidase activity when compared with WT mice. Subsequently, we investigated the multiple organ dysfunctions in septic mice by measuring serum levels of creatine kinase-MB (CK-MB), a marker of heart muscle damage; blood-urea-nitrogen (BUN), a marker of renal dysfunction; and alanine aminotransferase (ALT), which is a marker of liver damage. Consistent with the increased survival, Gal-3 KO mice showed a significant reduction in serum levels of all biochemical indicators of organ injury and dysfunction when compared to WT mice (Figure 4 B-D). Taken together, our data suggest that higher galectin-3 levels is associated with organ dysfunction observed during the course of sepsis.

\subsection{Galectin-3 deficiency prevents impairment of neutrophil migration in lethal polymicrobial sepsis}

Neutrophils migration to specific infectious sites is essential to bacterial spread control. There is data showing that galectin-3 may bind to neutrophil membrane and inhibit its spontaneous migration and the chemotaxis towards classical chemoattractants like complement C5a, ATP or chemokine (C-X-C motif) ligand 1 (CXCL1), also called KC, a functional homologue of human IL-8 (Baseras et al., 2012). Since we found increased levels of galectin-3 in the serum of septic shock patients and mice underwent lethal sepsis (Figure 1 A and Figure 2 A), we analyzed the levels of galectin-3 on neutrophils surface. We found higher levels of galectin-3 bound on membrane of neutrophils recovered from septic mice in relation to neutrophil recovered from naïve mice (Figure $5 \mathrm{~A}$ and $\mathrm{B}$ ). To 
check the relevance of increased binding of galectin-3 on neutrophils membrane, we evaluated the number of this leukocyte in the peritoneal cavity of WT or Gal-3 KO mice underwent lethal sepsis. As shown in Figure 5 C, Gal-3 KO mice showed 3-fold higher number of neutrophils in the peritoneal cavity than WT mice $6 \mathrm{~h}$ after CLP. These data support the hypothesis that galectin-3 can impair neutrophils migration to infection focus during sepsis. Inflammatory chemokines are produced in high concentrations during infection and determine neutrophils migration through concentration gradients (Kolaczkowska et al., 2013). Thus, we evaluate the level of KC, in infectious focus $6 \mathrm{~h}$ after CLP. There was not difference in KC levels in peritoneal exudate recovered from WT and Gal-3 KO mice (Figure $5 \mathrm{D}$ ). This data suggest that other factors must explain the high neutrophils number found in galectin-3 peritoneal cavity after sepsis induction. Other important step in the control of neutrophil migration to infectious focus is the rolling and adhesion process. Thus, we used Intravital Microscopy Imaging Approaches to visualize leukocyte rolling and adhesion to the mesenteric vessels of WT or Gal-3 KO mice $3 \mathrm{~h}$ after CLP. As shown in Figure $5 \mathrm{E}$ and F, Gal-3 KO mice leukocytes exhibited an enhanced rolling and adhesion capacity in comparison with WT mice underwent CLP. Taken together, these data suggest that Gal-3 impair neutrophils rolling and adhesion to the mesenteric vessels, what explain the reduced number of these cells found in the peritoneal cavity of WT mice.

\section{Discussion}

Data presented here show an increase in galectin-3 production in serum of human with septic shock and mice underwent lethal sepsis. This result is in 
agreement with the data showed by Ten Oever, 2013, where high galectin-3 level was detected in circulation of patients with infections but not in patients with non-infectious diseases. Moreover, we found that high galectin-3 level correlated with sepsis severity in humans suggesting that galectin-3 might be used as a biomarker of sepsis. Biomarkers can be useful for identifying or exclude sepsis, identifying patients who can benefit from specific therapies or/and assessing the response to therapy (Pierrakos et al., 2010). Moreover, the early diagnosis and stratification of the severity of sepsis is very important, once starting treatment as soon as possible, increases the chances for patient recovery (Pierrakos et al., 2010; Cohen et al., 2015).

Lately, the participation of galectin-3 in inflammation and host defense mechanisms has been recognized, but some contradictory results have been presented. Gal-3 KO mice are more susceptible to endotoxemic shock due to increase of cytokines and NO production. However, these mice are more resistant to Salmonella infection ( $\mathrm{Li}$ et al., 2008). Our data showed that the absence of galectin-3 protected mice from severe polymicrobial sepsis induced by lethal CLP surgery, considered the most relevant experimental sepsis model for clinical studies (Hubbard et al., 2005; Dejager et al., 2011).

Sepsis may be originate from a localized infection. Furthermore, severe cases often result from a bacterial infection that spread through the bloodstream. In this sense, experiments were conducted in order to evaluate bacteria spread in WT or Gal-3 KO mice after CLP. We found that Gal-3 KO mice showed reduced bacterial load in the infectious focus, blood and lung. There is evidences that 
some galectins may recognize and kill bacteria directly (Stowell et al., 2010). These data demonstrate that bacterial control during sepsis does not depend of a direct action of galectin-3 on bacteria surface and suggest that other player is important to control bacteria spread during sepsis.

During severe sepsis neutrophils are systemically stimulated. This process will favor the recruitment of neutrophil to distant organs leading to release of its intracellular toxics components corroborating to endothelial injury, capillary occlusion and consequently to hypoperfusion. Moreover, these processes are associated with organ damage culminating in the aggravation of sepsis and in many cases leading to death (Souto et al., 2011; Sonego et al., 2016). Here, we found that Gal-3 KO mice presented reduced lung myeloperoxidase activity, an indirect mark of lung neutrophils accumulation, which is considered a sign of tissue damage (Souto et al., 2011). In line with this data, Gal-3 KO mice also presented reduction in markers of heart, kidney and liver damage. These results explain the higher mortality found in WT mice and support a deleterious role of galectin-3 during sepsis.

Neutrophil are the main cellular component of the innate immune system providing the first line of defense against microorganisms in sepsis (Alves-Filho et al., 2010). These cells are recruited and activated into the infectious focus, phagocytizing microorganisms and releasing toxic mediators, including reactive oxygen species (Kolaczkowska et al., 2013). The presence of neutrophils at the site of infection has been demonstrated to be essential for controlling the bacterial avoiding the systemic spread of the infection (Ermert et al., 2009). 
Indeed, depletion of neutrophils in mice infected with Staphylococcus aureus markedly reduced the clearance of the bacteria and survival (Robertson et al., 2008). Similarly, depletion of neutrophils in mice infected with Candida albicans induced dissemination of the fungus and led to a higher mortality rate. Likewise, neutropenic patients are more susceptible to bacterial and fungal infections (Bouma et al., 2010; Brown et al., 2012; Swamydas et al., 2016).

Published data showing that galectin-3 may bind to neutrophils membrane and inhibits spontaneous migration and the chemotaxis towards classical chemoattractants (Baseras et al., 2012). In agreement with these data, we found increased galectin-3 concentration in blood serum of septic shock patients and mice underwent lethal sepsis. Moreover, our data demonstrated that Gal-3 KO mice were less susceptible to bacteremia than WT counterparts due an efficient neutrophil recruitment toward the site of infection. The higher number of neutrophils was not dependent of chemokine production, once we did not find difference in $\mathrm{KC}$ levels in the infectious focus.

A crucial step that regulates neutrophil recruitment from vessels to infectious focus is the rolling and adhesion process (Kolaczkowska et al., 2013). Our results demonstrate for the first time that complete lacks of galectin-3 improve leukocyte rolling and adhesion to mesenteric venules after lethal sepsis induction. Currently, there is not data about the role of galectin-3 in the failure of neutrophil migration to the infectious site during sepsis (Alves-Filho et al., 2010). Is important mention that the mechanisms by which galectin-3 reduces 
leukocyte rolling and adhesion in this lethal sepsis conditions is still under investigation (Baseras et al., 2012).

In summary, our results demonstrated that galectin-3 absence prevented the failure of neutrophil migration and, consequently, bacterial spreading, which has been associated with multiple organ dysfunction syndrome and death. Moreover, galectin-3 is an endogenous molecule that contributes to the severity of sepsis. In this sense, previous studies already suggested that it may be used as a marker on severe sepsis (ten Oever et al., 2013). We here propose that galectin-3 may be also used as a potential target to the sepsis treatment.

\section{Acknowledgements}

This work was supported by FAPESP project grant (2012/11312-0) and CNPq project grant (142070/2012-2).

\section{References}

Abraham E (2016). New Definitions for Sepsis and Septic Shock: Continuing Evolution but With Much Still to Be Done. JAMA 315(8): 757-759.

Alves-Filho JC, de Freitas A, Russo M, Cunha FQ (2006). Toll-like receptor 4 signaling leads to neutrophil migration impairment in polymicrobial sepsis. Crit Care Med 34(2): 461-470.

Alves-Filho JC, Freitas A, Souto FO, Spiller F, Paula-Neto H, Silva JS, et al. (2009). Regulation of chemokine receptor by Toll-like receptor 2 is critical to neutrophil migration and resistance to polymicrobial sepsis. Proc Natl Acad Sci U S A 106(10): 4018-4023.

Alves-Filho JC, Sonego F, Souto FO, Freitas A, Verri WA, Jr., Auxiliadora-Martins M, et al. (2010). Interleukin-33 attenuates sepsis by enhancing neutrophil influx to the site of infection. Nat Med 16(6): 708-712.

Baseras B, Gaida MM, Kahle N, Schuppel AK, Kathrey D, Prior B, et al. (2012). Galectin-3 inhibits the chemotaxis of human polymorphonuclear neutrophils in vitro. Immunobiology 217(1): 83-90. 
Bouma G, Ancliff PJ, Thrasher AJ, Burns SO (2010). Recent advances in the understanding of genetic defects of neutrophil number and function. Br J Haematol 151(4): 312-326.

Brown GD, Denning DW, Gow NA, Levitz SM, Netea MG, White TC (2012). Hidden killers: human fungal infections. Science translational medicine 4(165): 165 rv113.

Cohen J, Vincent JL, Adhikari NK, Machado FR, Angus DC, Calandra T, et al. (2015). Sepsis: a roadmap for future research. Lancet Infect Dis 15(5): 581-614.

Dejager L, Pinheiro I, Dejonckheere E, Libert C (2011). Cecal ligation and puncture: the gold standard model for polymicrobial sepsis? Trends in microbiology 19(4): 198-208.

Deutschman CS, Tracey KJ (2014). Sepsis: current dogma and new perspectives. Immunity 40(4): 463-475.

Ermert D, Zychlinsky A, Urban C (2009). Fungal and bacterial killing by neutrophils. Methods in molecular biology 470: 293-312.

Freitas A, Alves-Filho JC, Trevelin SC, Spiller F, Suavinha MM, Nascimento DC, et al. (2011). Divergent role of heme oxygenase inhibition in the pathogenesis of sepsis. Shock 35(6): 550559.

Henderson NC, Sethi T (2009). The regulation of inflammation by galectin-3. Immunol Rev 230(1): 160-171.

Hubbard WJ, Choudhry M, Schwacha MG, Kerby JD, Rue LW, 3rd, Bland KI, et al. (2005). Cecal ligation and puncture. Shock 24 Suppl 1: 52-57.

Kolaczkowska E, Kubes P (2013). Neutrophil recruitment and function in health and inflammation. Nat Rev Immunol 13(3): 159-175.

Levy MM, Fink MP, Marshall JC, Abraham E, Angus D, Cook D, et al. (2003). 2001 SCCM/ESICM/ACCP/ATS/SIS International Sepsis Definitions Conference. Crit Care Med 31(4): $1250-1256$.

Li Y, Komai-Koma M, Gilchrist DS, Hsu DK, Liu FT, Springall T, et al. (2008). Galectin-3 is a negative regulator of lipopolysaccharide-mediated inflammation. J Immunol 181(4): 27812789.

Nascimento DC, Alves-Filho JC, Sonego F, Fukada SY, Pereira MS, Benjamim C, et al. (2010). Role of regulatory $T$ cells in long-term immune dysfunction associated with severe sepsis. Crit Care Med 38(8): 1718-1725. 
Pierrakos C, Vincent JL (2010). Sepsis biomarkers: a review. Crit Care 14(1): R15.

Rabinovich GA, Toscano MA (2009). Turning 'sweet' on immunity: galectin-glycan interactions in immune tolerance and inflammation. Nat Rev Immunol 9(5): 338-352.

Robertson CM, Perrone EE, McConnell KW, Dunne WM, Boody B, Brahmbhatt T, et al. (2008). Neutrophil depletion causes a fatal defect in murine pulmonary Staphylococcus aureus clearance. J Surg Res 150(2): 278-285.

Shankar-Hari M, Phillips GS, Levy ML, Seymour CW, Liu VX, Deutschman CS, et al. (2016). Developing a New Definition and Assessing New Clinical Criteria for Septic Shock: For the Third International Consensus Definitions for Sepsis and Septic Shock (Sepsis-3). JAMA 315(8): 775787.

Sonego F, Castanheira FV, Ferreira RG, Kanashiro A, Leite CA, Nascimento DC, et al. (2016). Paradoxical Roles of the Neutrophil in Sepsis: Protective and Deleterious. Frontiers in immunology 7: 155.

Souto FO, Alves-Filho JC, Turato WM, Auxiliadora-Martins M, Basile-Filho A, Cunha FQ (2011). Essential role of CCR2 in neutrophil tissue infiltration and multiple organ dysfunction in sepsis. Am J Respir Crit Care Med 183(2): 234-242.

Stowell SR, Arthur CM, Dias-Baruffi M, Rodrigues LC, Gourdine JP, Heimburg-Molinaro J, et al. (2010). Innate immune lectins kill bacteria expressing blood group antigen. Nat Med 16(3): 295-301.

Swamydas M, Gao JL, Break TJ, Johnson MD, Jaeger M, Rodriguez CA, et al. (2016). CXCR1mediated neutrophil degranulation and fungal killing promote Candida clearance and host survival. Science translational medicine 8(322): 322ra310.

ten Oever J, Giamarellos-Bourboulis EJ, van de Veerdonk FL, Stelma FF, Simon A, Janssen M, et al. (2013). Circulating galectin-3 in infections and non-infectious inflammatory diseases. European journal of clinical microbiology \& infectious diseases : official publication of the European Society of Clinical Microbiology 32(12): 1605-1610. 


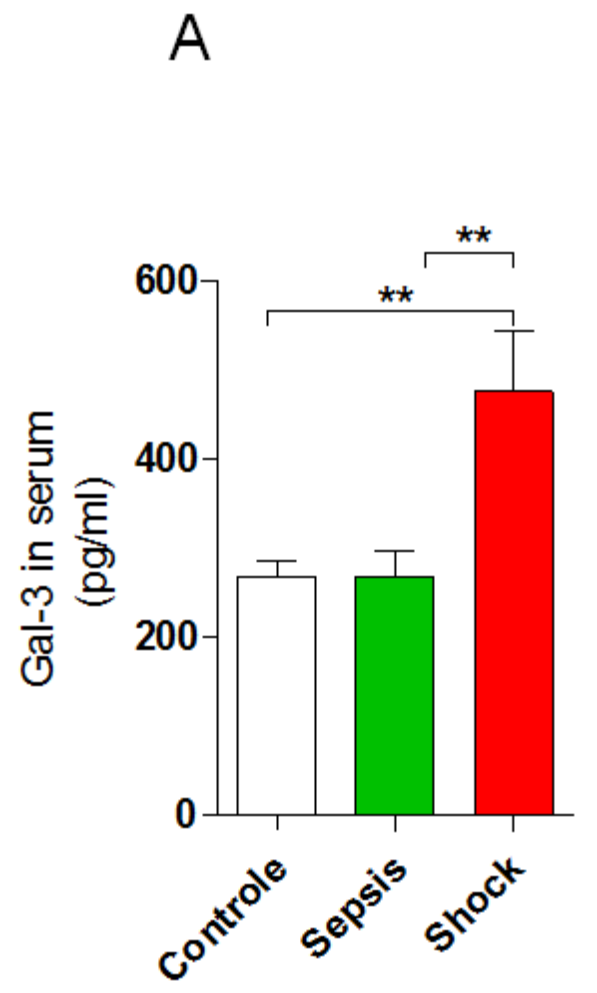

B

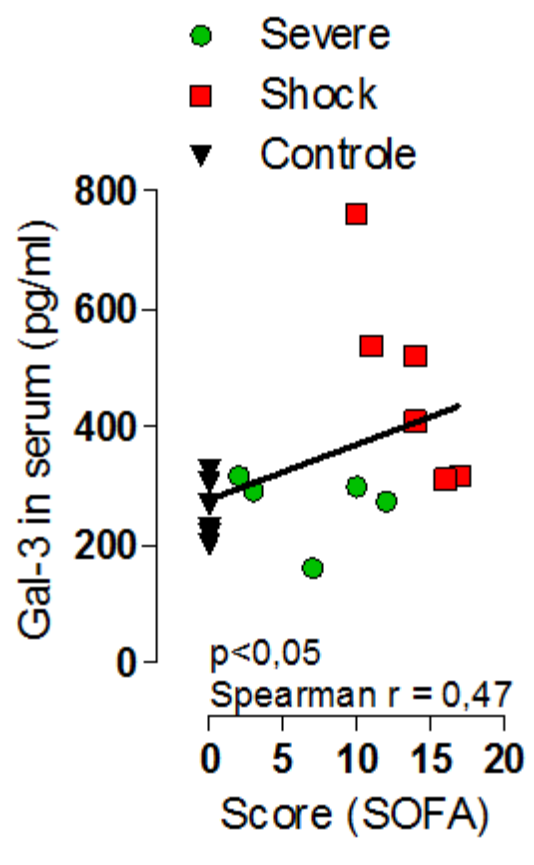

Fig. 1. Increased galectin-3 levels correlate with severity of sepsis in human. Eleven adult patients were admitted to the Emergency Department of Ribeirão Preto Medical School with sepsis and/or septic shock. Eight healthy volunteers were also included in the study. Peripheral blood samples were collected from all patients immediately after sepsis diagnosis. (A) Measurements of galectin-3 was done by enzyme-linked immunosorbent assay (ELISA). (B) Association between galectin-3 levels in serum of patients and severity of sepsis. Spearman rank test was used to measure the strengths of correlation. Results are presented as mean \pm S.E.M of $5-6$ mice per group. ${ }^{*} p<0.05$; ${ }^{* *} p<0.01$; ${ }^{* * *} p<0.001$ (One-way ANOVA followed by Bonferroni's multiple comparison test). 
A

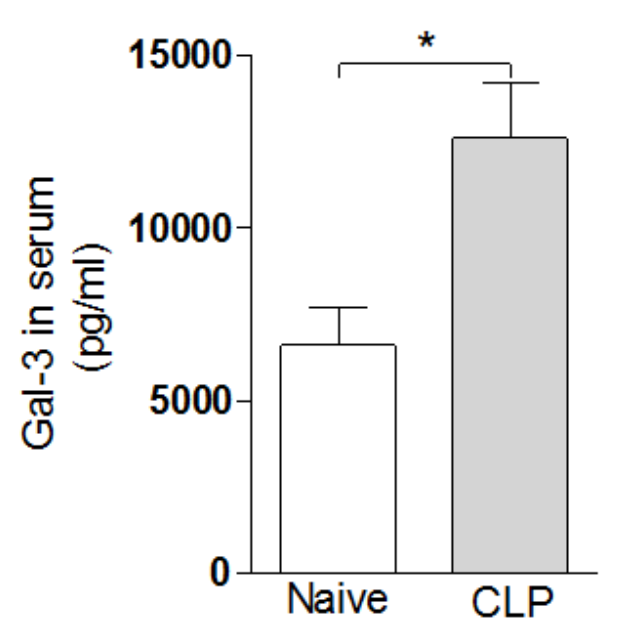

B

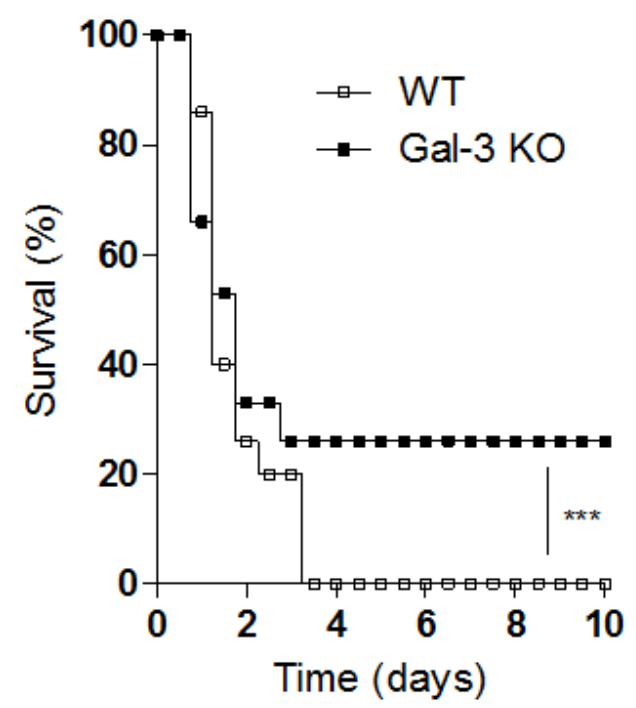

Fig. 2. Galectin-3 is associated with sepsis-increased mortality. To induce severe sepsis, WT and Gal-3 KO mice were submitted to cecal ligation and puncture (CLP) model. (A) Galectin-3 level in blood serum of mice 6h after CLP. The results are expressed as the mean \pm S.E.M of 6-11 mice per group. ${ }^{*} p<0.05$ (One-way ANOVA followed by Bonferroni's multiple comparison test) (B) For survival rate analysis mice were monitored every $12 \mathrm{~h}$ after CLP during 7 days. $n=15$ mice per group ${ }^{* *} p<0.001$ (Chi-square test). 
A

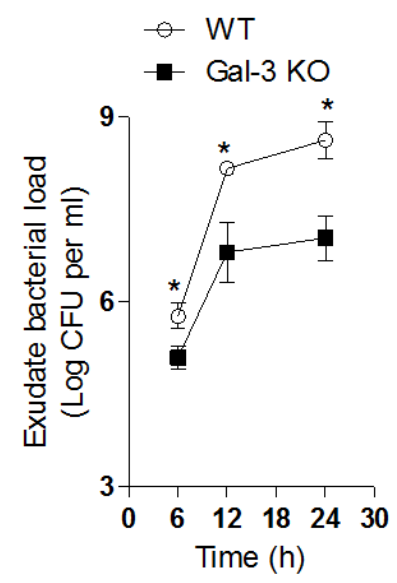

B

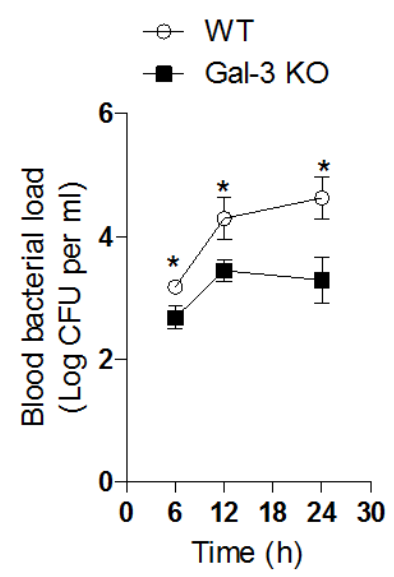

C

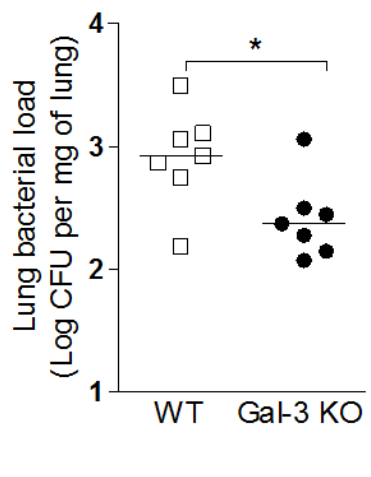

Fig. 3. Galectin-3 KO mice (Gal-3 KO) underwent severe sepsis display reduced bacterial clearance after severe polymicrobial sepsis induction. To induce severe sepsis, WT and Gal-3 KO mice were submitted to cecal ligation and puncture (CLP) model. Bacterial counts was evaluated in peritoneal exudate (Panel A) or blood serum (Panel B) of mice 6, 12 and $24 \mathrm{~h}$ after surgery. Specifically in lung, bacterial counts, was evaluated $6 \mathrm{~h}$ after CLP (Panel $\mathrm{C}$ ). The results are expressed as the log of colony-forming units (CFUs) per milliliter of blood or peritoneal exudate and are represented as mean \pm S.E.M of 4-8 mice per group. ${ }^{*} p<0.05$ (Student's $t$ test to compare the differences between groups). 
A

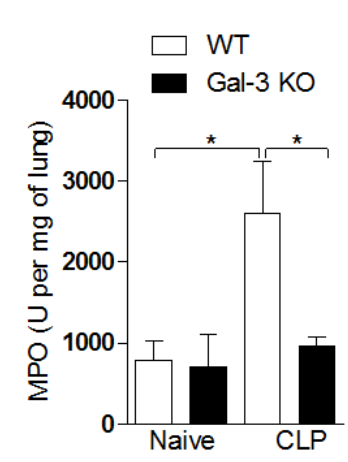

B

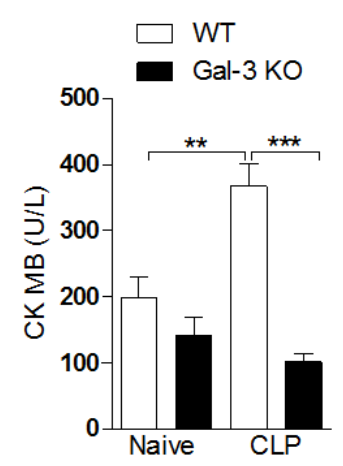

C

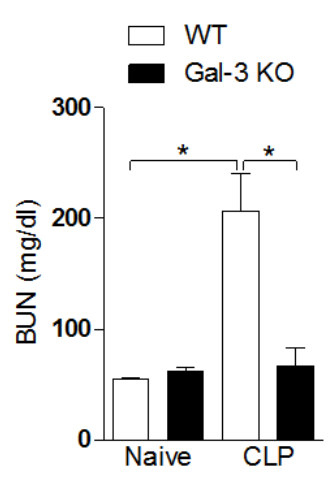

D

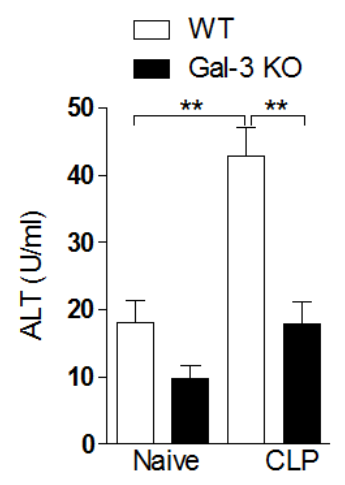

Fig. 4. Galectin-3 KO mice (Gal-3 KO) underwent severe sepsis display reduced sepsis-induced organ dysfunction in relation to Wild type (WT) mice. To induce severe sepsis, WT and Gal-3 KO mice were submitted to cecal ligation and puncture (CLP) model. Myeloperoxidase (MPO) activity was evaluated in lung $6 \mathrm{~h}$ after surgery (Panel A). The activity of CK MB (Panel A) was quantified $6 \mathrm{~h}$ after surgery in serum. The ALT activity and BUN levels (Panel $C$ and $D$ ) were quantified $24 \mathrm{~h}$ after surgery in serum. The results are represented as the mean \pm S.E.M of $2-8$ mice per group. ${ }^{*} p<0.05 ;{ }^{* *} p<0.01$; ${ }^{* * *} p<0.001$ (One-way ANOVA followed by Bonferroni's multiple comparison test) 
A
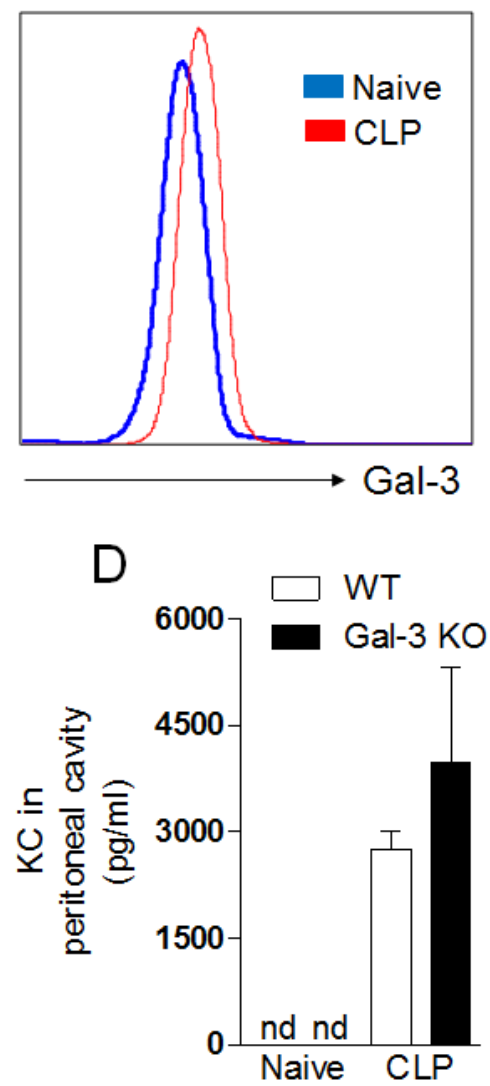

B

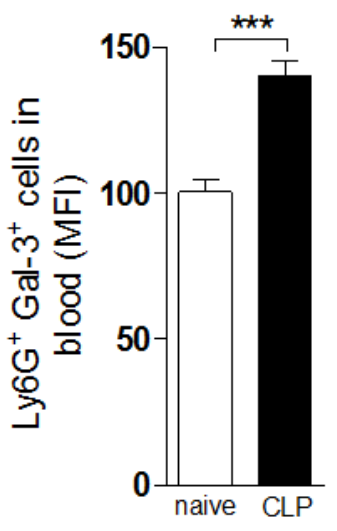

E

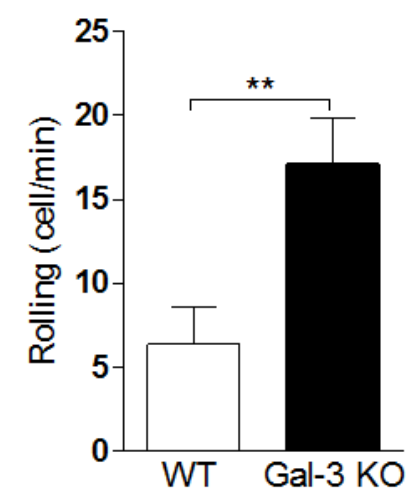

C

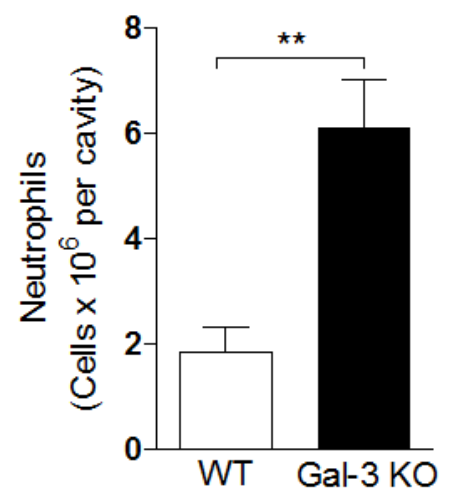

$\mathrm{F}$

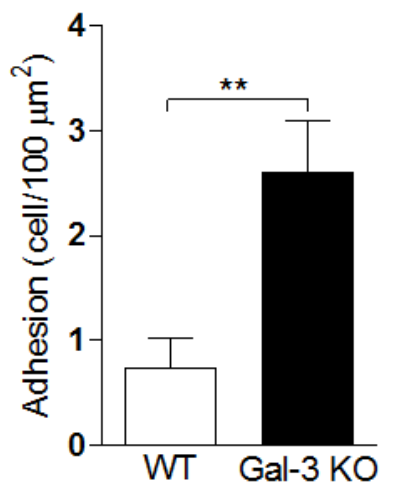

Fig. 5. Galectin-3 impair neutrophils migration to infectious focus. To induce severe sepsis, WT and Gal-3 KO mice were submitted to cecal ligation and puncture (CLP) model. (A-B) Histogram and Median Fluorescent Intensity (MFI) of membrane-bound galectin-3 on the blood neutrophils $6 \mathrm{~h}$ after CLP. (C) Neutrophil number in peritoneal exudate of WT and Gal-3 KO mice $6 \mathrm{~h}$ after CLP. (D) ELISA of KC. (E-F) Intravital microscopy of rolling and adherent leukocyte in mesenteric venules $3 \mathrm{~h}$ after CLP. The results are expressed as the mean \pm S.E.M of $3-7$ mice per group. ${ }^{* *} p<0.01 ;{ }^{* *} p<0.001$ (One-way ANOVA followed by Bonferroni's multiple comparison test) 
Supplementary Table 1

Demographic and clinical characteristics of septic patients

\begin{tabular}{lc}
\hline \multicolumn{1}{c}{ Patients } & $\mathbf{n = 1 1}$ \\
\hline Age (years) - mean (SD) & $59,0( \pm 9,45)$ \\
Female sex - number (\%) & $2(18,18)$ \\
APACHE II - mean (SD) & $20,09( \pm 6,64)$ \\
SOFA - mean (SD) & $10,55( \pm 3,77)$
\end{tabular}

SD: standard deviation, APACHE II: Acute Physiology and Chronic Health Evaluation II, SOFA: Sepsis-related Organ Failure Assessment 
Supplementary Table 2

Clinical characteristics of septic patients

\begin{tabular}{|c|c|c|c|}
\hline Patients & Site of Infection & $\begin{array}{l}\text { Severity of } \\
\text { sepsis }\end{array}$ & Microorganisms isolated \\
\hline 1 & Skin & Sepsis & Negative \\
\hline 2 & $\begin{array}{l}\text { Respiratory } \\
\text { system }\end{array}$ & Sepsis & Negative \\
\hline 3 & Urinary System & Sepsis & $\begin{array}{l}\text { Pseudomonas sp/ } \\
\text { Enterobacter cloacae }\end{array}$ \\
\hline 4 & $\begin{array}{l}\text { Meningitis/Urinary } \\
\text { System }\end{array}$ & Sepsis & $\begin{array}{c}\text { Pseudomonas sp / } \\
\text { Klebsiella sp }\end{array}$ \\
\hline 5 & Abdominal & Sepsis & $\begin{array}{c}\text { Morganella morganii / } \\
\text { Streptococcus anginosus }\end{array}$ \\
\hline 6 & $\begin{array}{l}\text { Respiratory } \\
\text { system }\end{array}$ & $\begin{array}{l}\text { Septic } \\
\text { Shock }\end{array}$ & Stafilococcus epidermidis \\
\hline 7 & Abdominal & $\begin{array}{l}\text { Septic } \\
\text { Shock }\end{array}$ & Escherichia coli \\
\hline 8 & $\begin{array}{l}\text { Respiratory } \\
\text { system }\end{array}$ & $\begin{array}{l}\text { Septic } \\
\text { Shock }\end{array}$ & Negative \\
\hline 9 & $\begin{array}{l}\text { Respiratory } \\
\text { system }\end{array}$ & $\begin{array}{l}\text { Septic } \\
\text { Shock }\end{array}$ & $\begin{array}{c}\text { Staphylococcus } \\
\text { haemolyticus / Klebsiella } \\
s p\end{array}$ \\
\hline 10 & $\begin{array}{l}\text { Respiratory } \\
\text { system/Skin }\end{array}$ & $\begin{array}{l}\text { Septic } \\
\text { Shock }\end{array}$ & $\begin{array}{l}\text { Staphylococcus } \\
\text { haemolyticus }\end{array}$ \\
\hline 11 & Urinary system & $\begin{array}{l}\text { Septic } \\
\text { Shock }\end{array}$ & Staphylococcus aureus \\
\hline
\end{tabular}

